INTERNATIONAL MONETARY FUND

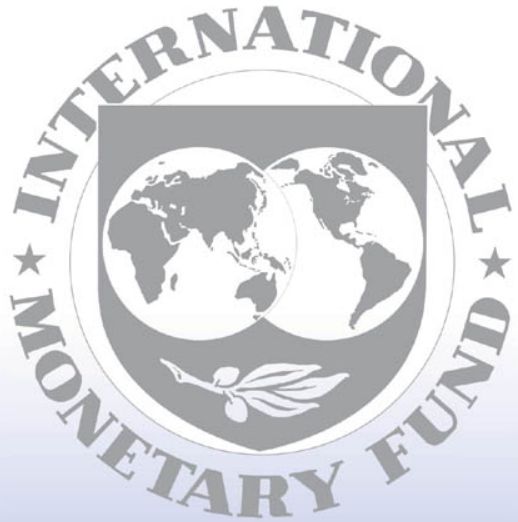

Staff

Country

Reports 


\section{Rwanda: Poverty Reduction Strategy Paper-Progress Report}

Poverty Reduction Strategy Papers (PRSPs) are prepared by member countries in broad consultation with stakeholders and development partners, including the staffs of the World Bank and the IMF. Updated every three years with annual progress reports, they describe the country's macroeconomic, structural, and social policies in support of growth and poverty reduction, as well as associated external financing needs and major sources of financing. This country document for Rwanda, dated March 2011, is being made available on the IMF website by agreement with the member country as a service to users of the IMF website.

Copies of this report are available to the public from

International Monetary Fund $\bullet$ Publication Services

$70019^{\text {th }}$ Street, N.W. $\bullet$ Washington, D.C. 20431

Telephone: (202) 623-7430 • Telefax: (202) 623-7201

E-mail: publications@imf.org Internet: http://www.imf.org

\section{International Monetary Fund \\ Washington, D.C.}




\section{REPUBLIC OF RWANDA}

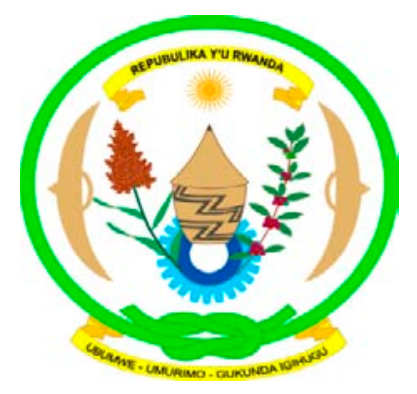

3-YEARS OF THE

ECONOMIC DEVELOPMENT AND POVERTY REDUCTION STRATEGY (EDPRS)

\section{A SUMMARY IMPLEMENTATION REPORT}

2008-2010

MINECOFIN MARCH 2011

CInternational Monetary Fund. Not for Redistribution 


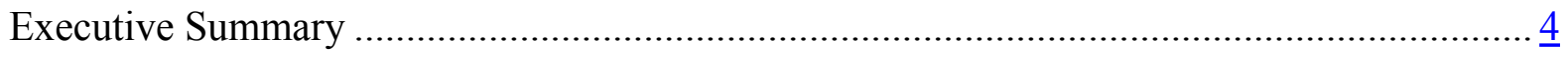

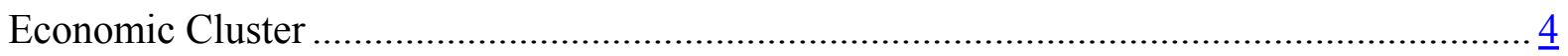

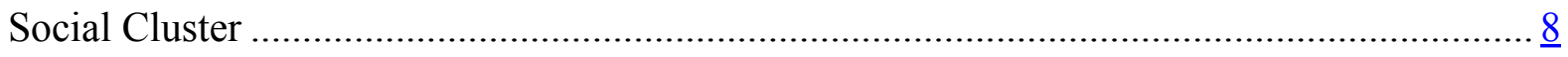

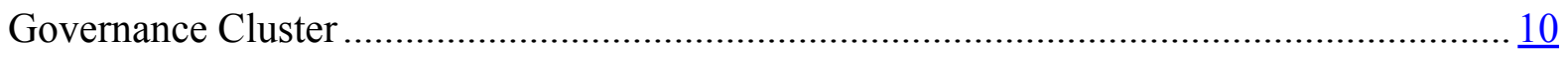

Conclusions and Key Issues ........................................................................................ 12 Appendices

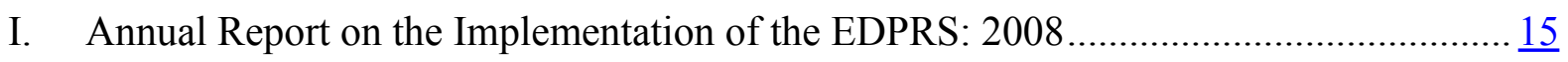

II. EDPRS Implementation Report: January-June 2009 ................................................. 104

III. Annual Report on the Implementation of the Economic Development and Poverty Reduction Strategy (EDPRS): July 2009-June 2010.............................................. 156 


\section{LIST OF ABBREVIATIONS}

$\begin{array}{ll}\text { COOJAD } & : \text { Cooperative Bank for Youth Self Employment and development } \\ \text { CPAF } & : \text { Common Performance Assessment Framework } \\ \text { DCPETA } & : \text { Decentralization, Citizen Participation, Empowerment, Transparency and Accountability } \\ \text { DHS } & : \text { Demographic and Health Survey } \\ \text { EAC } & : \text { East African Community } \\ \text { EDPRS } & : \text { Economic Development and Poverty Reduction Strategy } \\ \text { GDP } & : \text { gross domestic product } \\ \text { HIV } & : \text { Human Immunodeficiency Virus } \\ \text { HLI } & : \text { Higher Learning Institutions } \\ \text { HMIS } & : \text { health management information system } \\ \text { ICT } & : \text { Information and Communication Technology } \\ \text { JRLO } & : \text { Justice Reconciliation Law and Order } \\ \text { JSR } & : \text { Joint Sector Review } \\ \text { LLITN } & : \text { Long Lasting Insecticide Treated Nets } \\ \text { MDGS } & : \text { Millennium Development Goals } \\ \text { MT } & : \text { Metric Tones } \\ \text { MW } & : \text { Mega Watts } \\ \text { NHRC } & : \text { National Human Rights Council } \\ \text { OAG } & : \text { Office of the Auditor General } \\ \text { OPBRC } & : \text { Output and Performance Based Road Contracts } \\ \text { PBF } & : \text { Performance based financing } \\ \text { PEFA } & : \text { Public Finance and Financial Accountability } \\ \text { VUP } & : \text { Public Finance Management } \\ \end{array}$




\section{EXECUTIVE SUMMARY}

Rwanda's Economic Development and Poverty Reduction Strategy (EDPRS) covers the period 2008-2012 and provides a medium-term framework for achieving the country's long term development aspirations as embodied in Rwanda Vision 2020, the seven year Government of Rwanda (GoR) programme and the Millennium Development Goals.

This 3 years report covers $2008-2010$ and is based principally on qualitative and quantitative information gathered over a three year period from all stakeholders in Rwanda's development efforts, including government ministries and agencies, donors, and implementing partners. This report summarizes key progress made in 2008, 2009 mini-budget (6months) and 2009/10 in implementation of the Economic Development and Poverty Reduction Strategy (EDPRS) based on the selected targets and policy actions defined in the EDPRS Results and Policy Matrix and the Common Performance Assessment Framework (CPAF) as agreed between the GoR and the Development Partners. The report is organized in 3 EDPRS flagship programs that are aligned to the three clusters namely the Economic, Social and Governance clusters that were established by the Leadership Retreat in February 2009.

\section{ECONOMIC CLUSTER}

This cluster covers the macro and financial sector alongside the economic sectors of agriculture, infrastructure (energy, transport, ICT and STI) private sector development as well as environment and natural resources management.

\section{Macro and financial sector}

Growth performance in 2008 was higher than the projected rate of 8.5 percent at 11.5 percent. This growth was driven by a rebound in agriculture and continued buoyancy in the industry and services sectors.

In the fiscal year 2009/10, GDP at current prices was estimated to be Rwf 3,160 billion up from Rwf 2,843 billion in the year ending June 2009. In this fiscal year, the population of Rwanda was estimated at 10.2 million people. GDP per head was therefore Rwf 308,000 or US\$ 541 at the nominal exchange rate of Rwf 569 to 1 US dollar.

The GDP estimates calculated at constant 2006 prices show that in 2009/10 the GDP was 6.2\% higher in real terms than it was in 2008/09. This follows an increase of $9.8 \%$ from 2007/08 to $2008 / 09$. This growth rate is mainly attributed to growth of $5.9 \%$ in agriculture (mainly driven by a $7 \%$ increase in the food crop production), and $7.6 \%$ for services (in which public administration grew by $10 \%$ and business services by $13 \%$ ). The industry sector registered a modest growth of $0.6 \%$ as the sector that was most affected by the global recession and the domestic liquidity crunch.

There was an expansion in credit to the private sector which grew to $14 \%$ percent of GDP by end-2008. In the year 2009/10, taking into account potential effects of the domestic liquidity crunch, the Government was targeting credit to private sector of $12.2 \%$ of GDP (reduced from $14 \%$ in 2008), however, this was not achieved. 
Revenue in 2008 outperformed the projections by RWF 52 billion reflecting increased collection, higher inflation and GDP growth as well as large one-off non-tax revenue earnings. In 2009/10, total domestic revenue collections were RWF 391.5 billion (12.4\% of GDP), it exceeded the revised projected amount of RWF 385.1 billion by about RWF 6.4 billion. Higher collections from direct taxes and some indirect taxes offset shortfalls under taxes on international trade and non tax revenues. Collections from PAYE contributed the largest share of the excess under direct taxes whilst collections from consumption taxes notably VAT was the main contributor to the excess under taxes on domestic goods and services. PAYE and VAT taxes continue to provide the largest shares of domestic revenue collections. In fiscal year July 2008/June 2009, these two categories of taxes contributed about $56 \%$ of tax revenue. In the fiscal year July 2009/June 2010, the share rose to about 59\%. This development is in line with Government policy to get the welloff in society to provide a larger share of resources for the development of the country as envisaged in the EDPRS.

Exports of goods and services also fell by $9 \%$, while the rate of increase in imported goods and services slowed to $7 \%$ from $17 \%$ in 2008/09. In 2008, revenue from strategic exports obtained was USD 185 million exceeding the target of USD 163 million and revenue from tourism activities also increased to USD 208 million from a target of USD 56 million. More recently, in $2009 / 10$, these two targets have been missed as an impact of the global slowdown on the economy; they ware respectively of USD 164 million (against a target of USD 198 million) for strategic exports and of USD 182 million (against a target of USD 208 million) for tourism.

The only target that was not met in 2008 was the annual end year average inflation which reached double figures at $15.4 \%$ compared to a single digit target that was set. The acceleration in inflation arose from; high international commodity prices and domestic pressures from rising prices of food and non-alcoholic beverages. However, the inflation showed signs of stabilizing towards the end of the year with an increase of only $0.7 \%$ between September and December 2008.

The inflation rate declined overall from 22.3\% in December 2008 to 10.1\% in June 2009 and continued to be low in 2010 and the annual change stood at $5.03 \%$ by end-June 2010 compared to $9.4 \%$ at the end of June 2009 (an annual average of $4.8 \%$ ).

\section{Private sector}

Rwanda was declared as the World's top reformer of business regulation in the Doing Business 2010 , becoming the first sub-Saharan country to hold this position. The country has made the big strides in becoming business friendly by introducing reforms in seven out of the 10 categories: Rwanda made it easier to start a business, register property, protect investors, trade across borders, and access credit. This resulted in it moving up from 141 to the $67^{\text {th }}$ position out of 183 countries on the Doing Business rankings. In the more recent Doing Business report 2011, Rwanda's position has further improved to $58^{\text {th }}$. As a consequence, the target of ranking in doing business has been exceeded.

The World Economic Forum's recently released Global Competitiveness Report ranked Rwanda as the $6^{\text {th }}$ most competitive market in sub-Saharan Africa, and among the world's best on indicators such as female participation in the labour force, staff training, and legal rights. Fitch 
Ratings recently upgraded Rwanda to a - B," citing Rwanda's - uninterrupted period of economic growth and significant improvement of its business environment.

In $2007 / 2008$, investment made up $17 \%$ of GDP, and in 2008/2009 is projected to make up $18 \%$, or RWF456 billion ( $\$ 791$ million). Increases in investment in recent years have been driven by a rapid increase in public construction expenditure, with private expenditure on machinery still suffering low growth.

At 2006 constant prices, in the fiscal year 2009/10 Government and Private Final Consumption Expenditure grew by $7 \%$ and $12 \%$ respectively. Gross Capital Formation in real terms fell back by $7 \%$ after two years of exceptional increases ( $24 \%$ and $28 \%)$. The ratio of investment to GDP in $2009 / 10$ stood at $21 \%$ in excess of the $18 \%$ target.

\section{Infrastructure}

Power production has increased and stabilized since the severe power shortages in 2004 and total installed capacity has increased from 45 MW in 2006 to $74.5 \mathrm{MW}$ in 2008 and 56MW generation capacity, exceeding the 2008 target of 50MW. In this area the target for 2009/10 has also been exceeded with a generation capacity augmented to $84 \mathrm{MW}$ against a target of $80 \mathrm{MW}$.

However, this has been achieved with significant reliance on imported diesel thermal generation where 20 MW Heavy Fuel Oil power plant was commissioned. Actions to further increase power production while reducing dependence on diesel include: (i) construction of Rukarara Hydro Power plant $(9.5 \mathrm{MW})$ is at $95 \%$ of completion ii) Methane gas to power plant: REC pilot plant has started gas extraction testing; (iii) The national electricity grid was extended; (iv) Construction of Nyabarongo hydropower (27 MW); (v) Construction for micro hydropower plants that will deliver around $10 \mathrm{MW}$.

The target for the number of electricity connections in 2008 was 100,000 connections and the performance realized was of 110,000 connections (approximately 5\% of households) from a baseline of 91,332 in 2006. In 2009/10 electricity connections reached 159,516 against the target of 139,000 . This was largely attributed to the successful implementation of the electricity network expansion rollout program initiated by the Ministry of infrastructure (MININFRA) supported by development partners.

The EDPRS target for the percentage of classified national road network in good condition was to move from $11 \%$ in 2006 to $16 \%$ in 2008 , this was exceeded with an actual performance of $18 \%$. On the percentage of classified district road network in good condition, the target was to move from $15 \%$ (2006) to $22 \%$ (2008), however, following the decentralization of the budget for district road maintenance to local governments, no reports were submitted by districts on this and as such no quality information could be reported against this target. Road condition survey of 2010 later revealed that overall condition of the National Road network has $53.8 \%$ in good condition hence exceeding the EDPRS target of the year 2012, which is $31 \%$. However the District Unpaved road network in good condition is $23 \%$ using IRI method, marginally below the target of $28 \%$ which was set using the data from Visual Inspection method.

Composite coverage network is now at more than $90 \%$ with the increased number of telecommunications operators following the introduction of Rwandatel and TIGO in addition to MTN that was already in the market. The competition has provided consumers with reduced cost 
of telecommunication services as subscription fee for mobile service was reduced down to zero francs, calling rates per minute was reduced by $32 \%$ from Rwf 147 in 2003 to Rwf 100 in 2008. The mobile telephone coverage is $92 \%$ of the total population who can use telephone. Furthermore, the layout of fiber optic allover the country raises expectations that cost of services will further reduce and access increase.

\section{Agriculture}

Rwanda's agricultural sector registered significant growth since 2008, contributing to the national economic. The increases in food and export crop production can be attributed to GoR's work in the areas of crop intensification, disease prevention and assistance to producers of traditional and non-traditional export crops, as well as good rains. These production increases have buffered Rwanda against the global food crisis and the associated rise in food prices in 2008. Thanks to efforts made in crop intensification, production has exceeded consumption for the last three years, for the first time since 1994. This was achieved, not by bringing greater tracts of fragile lands under cultivation, but by important yield increases. While arable area increased in 2010 by a mere $1 \%$, production increased by almost $6 \%$ over the previous year.

In 2008 , a total of 12,920 ha of terraces (4,760 ha radical and 8,160 ha of progressive terraces) were constructed. Terracing is increasingly being carried out by districts. The target for 2008 was to increase the area of land protected from 40 to $45 \%$ of all land requiring erosion protection, however due to the lack of data available on the total area of land requiring terracing, it has not possible to report against this indicator. In 2009/10, 80.9\% of land area was protected against soil erosion well above the targeted $50 \%$ for $2009 / 10$ and the target of $80 \%$ in 2012 .

On the indicator for the Proportion of farming households using improved methods, unfortunately, MINAGRI is unable to measure the use of fertilizer at the household level on an annual basis.

Another key food security indicator for the sector was the production in MT of key food security and export crops which targeted an increase by 30\% between 2006 and 2012. Crop production targets were exceeded for all key food security crops in 2008, with 166,853 MT of maize, 82,025 MT of rice, and 67,869 MT of wheat having been produced in 2008. Tea production also exceeded targets with a total production of 83,830 MT. In 2009/10, the production of key food security crops reached 2,997MT against the target of 1,000MT.

The use of fertilizer topped at 27,906 MT against the target of 30,800MT in 2009/10.

\section{Environment}

Currently, the surface land area coved by forest and agro-forest increased from $20,2 \%$ to $21 \%$ (plantation of 31.327 .410 trees on 19579 ha) against a target of $21.4 \%$ for $2009 / 10$ and the area of land protected to maintain biological diversity exceeded the target of $8.4 \%$ by an actual performance of $8.5 \%$ in 2008 and achieves exactly the target of $8.8 \%$ in $2009 / 10$.

The percentage of water resources complying with water quality standards was attained at $30 \%$.

The targets which were not met in 2008 both relate to land; the percentage of area of privately owned land held under written title was $1.26 \%$ compared to a target of $3 \%$ and the proportion of 
issued land titles owned by Women was $0.02 \%$ compared to a target of $2 \%$. One of them, on percentage of privately owned land held under written title was exceeded in 2009/10 as it reached $19.3 \%$ against a target of $10 \%$. The other has not been measured.

\section{SOCIAL CLUSTER}

This cluster covers Health, Water and Sanitation, Education, Social Protection, and Youth.

\section{The health sector}

The percentage of women using modern contraceptives increased from $10 \%$ in 2006 to $27 \%$ (mini DHS 2007/8) exceeding the target of $25 \%$ in 2008. This was further increased to $45.1 \%$ in $2009 / 10$ against the target of $32 \%$.

The percentage of children fully immunized increased from 75\% in 2006 to $80.4 \%$ (HMIS 2008), slightly exceeding the 2008 target of $80 \%$ and this has benefited from all health facilities carrying out outreach services for immunization. In 2009/10, this further improved to $90.4 \%$ against a target of $85 \%$.

On the indicator measuring the percentage of children using Long Lasting Insecticide Treated Nets (LLITN) , significant progress was made, however, the target of $65 \%$ was not fully realized with the mini-DHS (2007/8) reporting a score of $60 \%$ from a baseline of $16 \%$ in 2006 . The target for this indicator was largely achieved in $2009 / 10$, with an outcome of $79 \%$ of children fully immunized against a target of $70 \%$.

The percentage of assisted births in an accredited facility exceeded the target of $35 \%$ with a performance of $62.8 \%$ (HMIS 2008) coming from a baseline of $28.2 \%$ (2006). This was already above the EDPRS target for 2012. The percentage of assisted births in an accredited facility further increased to more than $66.2 \%$.

The utilization rate of primary health care services also increased from $70 \%$ to $86 \%$ in advance of the $75 \%$ target that was set for 2008 . This utilization rate moved from $86 \%$ to $95 \%$ in advance of the $80 \%$ target that was set for $2009 / 10$.

The target for per capita allocation to Performance-Based Financing (PBF) was not met fully with a realization of $\$ 1.40$ compared to a target of $\$ 1.45$ in 2008 and a baseline of $\$ 1.2$ in 2006 . The target has been missed again in 2009/10 with an allocation of $\$ 1.65 \%$ compared to a target of $\$ 1.85$.

With regard to fighting HIV/AIDS, while there is no data yet available on condom utilization by youth (15-24 years), respectively $96.5 \%$ of children and $95.5 \%$ of adults are still alive 12 months after start of treatment compared to respective targets of $89 \%$ and $86 \%$ for $2009 / 10$.

The proportion of population covered by a health insurance is of $91 \%$ against a target of $80 \%$ for 2009/10. 


\section{Water and Sanitation}

Rwanda has made significant progress towards achieving the Millennium Development Goals (MDGs) 2015 targets and the Vision 2020 target of $100 \%$ access to water. In 2008, 73\% (6.9 million) of population had access to safe water supply and (45\%), 4.3 million had access to hygienic sanitation from the $64 \%$ and $38 \%$ baselines of 2006 respectively. The annual target for 2008 access to safe drinking water was $70 \%$ which was surpassed and for hygienic sanitation systems was $45 \%$ which was met. In 2009/10, an estimated 7.62 million people equivalent to $76.2 \%$ Rwandans had access to safe drinking water supply within 500 Meters in rural areas and 200 Meters distance in urban areas. This is $2.2 \%$ increase compared to $74 \%$ access registered at the end of mid budget between January to June 2009. According to the EDPRS target, in 2012, access to clean drinking water within $500 \mathrm{~m}$ in rural areas is $86 \%$ and Rwanda is on track to meet this target.

Access to hygienic sanitation facilities is at $56.3 \%$ in $2009 / 10$ against a target of $50 \%$.

\section{Education}

There was an improvement in primary completion rate overall which was $52 \%$ in 2007 while in 2008 it was 53\% however, it did not meet the target of 55\%. In 2009/10, this area has improved a lot as Primary Completion Rates increased from $74.5 \%$ in 2009 to $75.6 \%$ in 2010 . Girls' primary completion $(79.8 \%)$ is markedly greater than for boys $(71.4 \%)$. All these are in excess of EDPRS targets for 2012 and well beyond those for 2009/10.

The student to qualified teacher ratio for primary school improved from 2008 to 2009 (passing from 67 to 1 to 63 to 1 ) and worsened from 2009 to 2010, reaching 68 to 1 , thereby missing the target of 65 to 1 for 2009/10.

In 2008 , the transition rate from basic education to upper secondary education fell behind the 2006 rate of $82 \%$ to $78.6 \%$ thereby failing to meet the target of $84 \%$. However, in $2009 / 10$, transition increased to $90.2 \%$ exceeding the target of $82 \%$.

The ratio of girl students enrolled in higher education institution in science courses (public institutions) remains at $30 \%$ and therefore did not meet the target of $32 \%$.

There was no update on the percentage of employers satisfied with the performance of TVET graduates as this indicator was due to be assessed through a survey in 2009.

\section{Social Protection}

The percentage of households in the bottom two categories of extreme poverty according to Ubudehe classification were $28.6 \%$ (VUP survey 2007), the progress however, could not be measured by lack of survey data.

Of the households eligible for support, the percentage granted public works was targeted at $35 \%$ which was exceeded at $91 \%$.

The percentage of households eligible for support and granted direct support in VUP sectors had reached $100 \%$ exceeding the target already in 2009 . 
The number of vulnerable households accessing credit and savings facilities exceeded the target of 6,390 to register 17,626 in 2009/10.

The VUP program is currently covering 90 sectors.

The key challenges are the Monitoring of graduation from livelihood enhancement schemes because graduation is not well defined. There is need to improve the coordination at both national and local levels as well as greater information sharing.

Youth; the sector did not have any quantitative indicators/targets to report against, however, it was responsible for the implementation of a number of policy actions which were all fully implemented. The target of supporting the transformation of fifty (50) youth associations into cooperatives was surpassed and in total, 61 associations were supported. Youth in all districts were sensitized to become members of COOJAD (a Youth Cooperative Bank for Self employment and Development.)

The Cooperative Bank for Youth Self Employment and Development (COOJAD) has opened its offices in 4 Districts: Nyagatare, Rulindo, Nyaruguru and Nyanza.

\section{GOVERNANCE CLUSTER}

The governance cluster brings together four sector working groups related to the areas of Public Financial Management (PFM), Justice, Reconciliation, Law and Order (JRLO), Decentralization, Community Participation, Empowerment, Transparency and Accountability (DCPETA), and Capacity Building and Employment Promotion (CBEP).

\section{Public Finance Management}

On the indicator on improved multiyear perspective in fiscal planning, expenditure policy and budgeting, in 2009/10, the expected Performance against CPAF Indicator is B- and the achieved results is $\mathrm{C}+$ (based on preliminary 2010 PEFA results) - There is still a need to improve forecasts for recurrent expenditure arising out of capital investments, as well as to strengthen the link between the costed sector strategies and aggregate fiscal forecasts.

On the index of effectiveness of payroll control, the scoring of PEFA 2010 was B against a target of $\mathrm{C}+$.

On the Index on quality and timeliness of annual financial statements, the scoring is $\mathrm{D}+$ against a target of B-

Percentage of internal audit reports submitted; 66 central government agencies and 22 local government agencies representing $30 \%$ of all budget agencies submitted internal audit report in 2008 . Hence, the $25 \%$ target was exceeded. The rate of reporting system by the budget agencies moved from $30 \%$ in 2008 to $45 \%$ in $2009 / 10$ against the set target of $40 \%$.

Percentage of Government expenditure audited by OAG; for the financial year that ending 31 st December 2007, the OAG audited $60 \%$ of the reported government expenditure, exceeding the $50 \%$ target set for the year. $70 \%$ of Government expenditure was audited by OAG during $2009 / 2010$ against set target of $65 \%$. 
Percentage of Public enterprises submitting fiscal reports; the $43 \%$ target has been met as all GBEs have submitted fiscal reports in 2008. 100\% of GBEs submitted their fiscal reports; all reports are consolidated in 2009/10.

Proportion of the value of procurement tendered competitively or justified; $86 \%$ of the contract value had been tendered competitively or justified in 2008 . Hence, the $75 \%$ target exceeded. According to the provisional 2010 PEFA assessment results based on the mini-budget, all procurement are being tendered competitively or justified, bringing the result at $100 \%$ for 2009/10, in excess of the end-EDPRS target.

\section{Justice, Reconciliation, Law and Order (JRLO)}

In $2008,75 \%$ out of 159 cases of corruption were processed by the Prosecutor, exceeding the $60 \%$ target. In $2009 / 10,81 \%$ were processed slightly above the target of $80 \%$.

With regards to the case backlog, both performance targets were exceeded, with 42,208 cases processed in 2008 and 62,278 in 2009/10; an increase of $41 \%$ against a target of $20 \%$.

Prison overcrowding was reduced from $140 \%$ in 2006 to $130 \%$ in 2008 , exceeding the $135 \%$ target. However in $2009 / 10$, the target of $125 \%$ was not achieved as it went up to $137 \%$ due to incoming cases from Gacaca courts.

The average time minors stay in prison before trial has not been measured.

There was also a reduction in the crime rate by $15 \%$ achieving the set target for 2008 while this declined by $7.23 \%$ in $2009 / 10$, short of the $20 \%$ target.

The indicator not met in 2008 was the proportion of human rights reports timely submitted due to untimely submission. However, in 2009/10, the target of $70 \%$ was exceeded with an achievement of $90 \%$.

\section{Decentralization, Citizen Participation Empowerment, Transparency and Accountability}

With regard to participation in JADF, all CSO and PS are members of JADF, thereby the $75 \%$ both targets for 2008 and $2009 / 10$ of $70 \%$ and $75 \%$ respectively have been exceeded.

In $2008,67 \%$ of districts achieved a minimum $80 \%$ of their service delivery targets (against a target of $62 \%$ ). This was of $67.2 \%$ in $2009 / 10$, against the target of $65 \%$.

Progress against the second target, percentage of citizens who feel they participate actively in local decision making and that local government is listening to and addressing their priority concerns was between $65 \%$ and $83.6 \%$ in $2009 / 10$ against a target of $72 \%$.

The challenge in this sector is the establishing and strengthening of partnerships in data collection and commissioning of surveys as well as establishing clear coordination and communication structure for partners and Government concerning the scope of the sector. 


\section{Capacity building and employment promotion}

The percentage of budget agencies which achieve a minimum of $80 \%$ of their action plans was $20 \%$ in 2008 and not measured in 2009/10.

The number of new non-farm jobs created was not assessed.

The key challenges in this sector are the funds mobilization for the internship program and the urgent need for macro level data on employment.

\section{CONCLUSIONS AND KEY ISSUES}

- In general, in 2008, implementation of the EDPRS is positive: $81 \%$ of the targets set were met or exceeded, with the strongest performance in the Governance cluster which had an overall implementation of $91 \%$ of targets, whilst the economic and social cluster achieved $78 \%$ and $75 \%$ respectively. With regard to the performance in implementing policy actions, overall performance was good with $80 \%$ achieved, $16 \%$ partially achieved and $4 \%$ not met.

- Over the mini budget 2009, a total of 107 policy actions were planned. Out of these, a total of 84 policy actions (79\%) were completed, 21 policy actions (19\%) were partially achieved and only 2 policy actions (2\%) were lagging significantly behind or had not commenced by the end of June 2009. During the mini-budget, the Social was the best implementer of policy actions.

The two policy actions that were not commenced are the establishment of the Axle Load control system for $50 \%$ of the National Paved Road Network and the signing of Multi Annual (3 years) Output and Performance Based Road Contracts (OPBRC's) by Districts in the Transport Sector under the economic cluster.

- In 2009/10, overall, out of 63 targets assessed, 54 (86\%) were fully achieved or exceeded, $7(11 \%)$ targets were partially achieved, and for $2(3 \%)$ targets we are significantly lagging behind. 10 outcomes were not assessed as they depended on surveys to be conducted later in the cycle of the EDPRS. The Governance cluster scored the worse with the most un-measured indicators and/or unmet targets

A total of $\mathbf{1 2 4}$ policy actions were planned for $2009 / 10$. Out of these, a total of 87 policy actions $(\mathbf{7 0 \%})$ were completed, 28 policy actions $(\mathbf{2 3 \%})$ were partially achieved and 9 policy actions $(\mathbf{7 \%})$ were lagging significantly behind.

- On the macro and financial side, implementation of the EDPRS and achievement of its targeted outcomes over the last three financial years have been impacted adversely by the effects of the global economic slowdown associated to the domestic liquidity crunch. It impacted on credit to private sector, exports, growth; however good rains and the crop intensification program have eased the effects on the domestic consumption. 
- Due to the remarkable increase in the agriculture production, a strong focus is to be put on the improvement of postharvest and strategic storage in order to minimize losses and to continue to tackle malnutrition

- The productions of coffee and tea have recorded low increases towards achieving EDPRS targets, not totally because of the global economic slowdown. There is need for focused and coordinated action in those areas addressing the whole value chain

- Entry into the EAC has shifted imports, with large imports of consumption goods in 2009; the effects on tax revenue from international trade have been negative; thereby putting pressure to seek for innovative ways of mobilizing other forms of taxes.

- Finalization of studies on assessment of legal, policy and institutions framework and Investment opportunities in EAC need to be speed up

- In various sectors, it was observed that some of the targets have been exceeded. In these areas the projections for the future need to be revised upwards in order to match with higher performances of clusters and their corresponding sectors.

- Higher than projected performance shows the efforts of Government and emphasis put on specific areas and, such as electricity and health. In this instance the organization of Leadership retreats and the concept of Imihigo (performance contracts) have promoted an effective mechanism of monitoring and evaluation of development initiatives, which is essential to promote focused development.

- However, in some instances, exceeded targets only translate lack of information and imperfect planning of targets, which afterwards proved to have been set lower than baselines.

- Lack of capacity (even in local private sector) to implement programs and projects: this has been cited as a challenge affecting delivery in the energy and transport sector. But it remains true for many other sectors. Delivery of a multi-sector capacity building program is therefore all the more important. Also lacking is PFM capacity at local government and facilities level

- Coordination for delivery and monitoring has also been challenge in some areas. It has been the case, for instance, for the maintenance and monitoring of district roads in good condition, it has also been the case in coordination of social protection interventions and DCEPTA sector. Recent developments in those sectors are expected to tackle this issue.

- Ambitious target setting and achievements against those target often hampered by shortage of resources for financing.

- Need for ex-post monitoring and evaluation to ensure positive outcome and is sustained and impact reached. 
- Need for closer follow up of tree plantation exercise to assess why in some areas there is high percentage loss of trees planted. Overall losses amounted to close to $30 \%$ of the trees planted in 2008 .

- Infrastructure construction (road, energy, fiber optic, etc.) and reforms (tariff revisions, financial services, doing business, etc.) need to effectively translate into reduced cost and risk of business, and improved opportunities.

- Continuous improvements are needed in indicators, targets, policy actions and their measurement.

- 10 out 73 indicators still not assessed after three financial years may point to the need to look for proxy indicators. They also point to the need to ensure that surveys and studies are executed without delays.

- Some outcomes are achieved while policy related policy actions are not. This point to the fact that some policy actions are not well linked to the outcome in terms of being key to its delivery.

- Performance in implementation of policy actions has declined with time, better in 2008 than in 2009 and worse in 2009/10. It is due to the tendency not to change policy actions once established for outer years. One needs to recognize that planning policy actions is easier for next year than more distant ones. 


\section{REPUBLIC OF RWANDA}

\section{MINISTRY OF FINANCE AND ECONOMIC PLANNING}

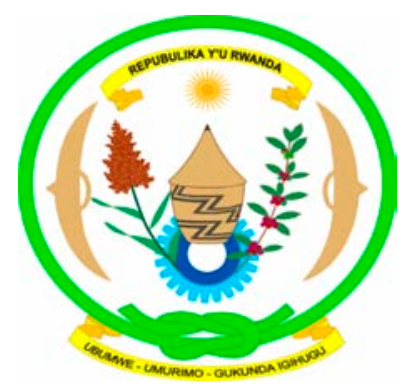

\section{ANNUAL REPORT ON THE IMPLEMENTATION OF THE ECONOMIC DEVELOPMENT AND POVERTY REDUCTION STRATEGY (EDPRS) - 2008}


Executive summary

2.1 Macro and financial sector

2.2 Private sector

2.3 Infrastructure Sector.

2.3.1 Energy Sub Sector

2.3.2 Transport Sub Sector

2.3.3 ICT and Science, Technology and Innovation sub sector.

2.4 Agriculture Sector

2.5 Environment and natural resources management.

3. Social cluster

3.1 Health sector

3.2 Water and sanitation sector

3.3 Education Sector.

3.4 Social protection Sector

3.5 Youth Sector

4. Governance cluster

4.1 Public Finance Management ...................................................................................................................................................

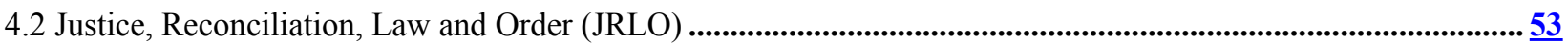

4.3 Decentralization, Citizen Participation, Empowerment, Transparency and Accountability (DCPETA) Sector .... $\underline{\mathbf{5 5}}$ 
4.4 Capacity Building and Employment Promotion (CBEP) Sector.....................................................................................

5. Integration of cross-cutting issues: progress and challenges...................................................................................5

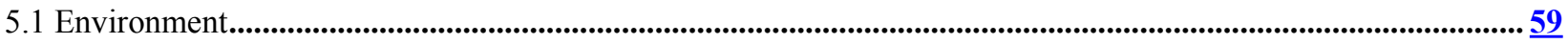

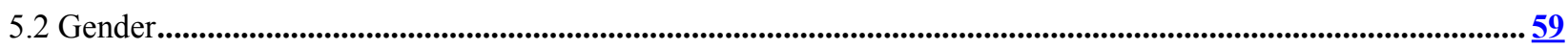

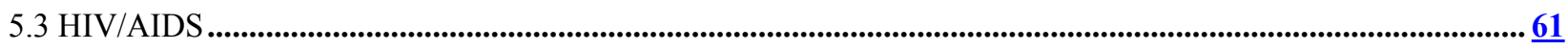

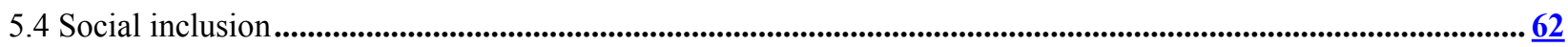

6. Aid harmonization and coordination...................................................................................................................................

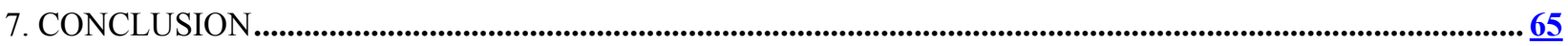

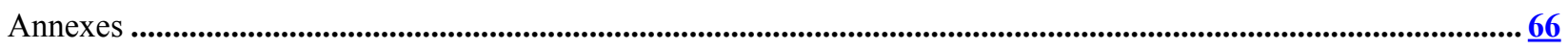

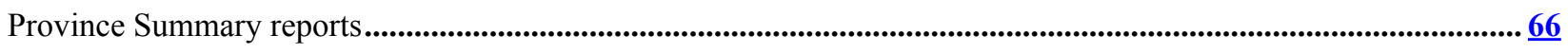

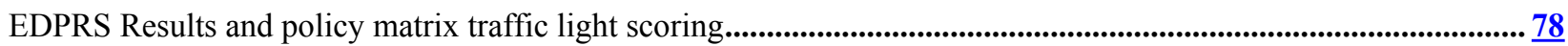




\section{LIST OF ABBREVIATIONS}

AADFI: Association of African Development Finance

ACH: Automatic Clearing House

ADF: African Development Fund

AFCR: Africa Food Crisis Response

AIDS: Acquired Immunodeficiency Syndrome

AMIR: Association of Microfinance Institutions

ATM: Automated Teller Machine

AWP: Annual Work Plans

BCR: Commercial Bank of Rwanda

BICS: Belgacom International Carrier Services

BNR: National Bank of Rwanda

BRALIRWA: Brasserie et Limonade du Rwanda

BRD: Rwanda Development Bank

BSHG: Budget Support Harmonization Group

C.E.O: Chief Executive Officer

CBEP: Capacity Building and Employment Promotion

CCI: Cross Cutting Issues

CFL : Carbon fluorescent lamps

CHW: Clinical Health Worker

CIP: Crop Intensification Group

CMAC: Capital Market Advisory Council

CNLS: National Commission for the Fight against AIDS

COMESA: Common Market for East and Southern Africa

COOJAD: Cooperative Bank for Youth Self Employment and development

CPAF: Common Performance Assessment Framework

DAD: Development Assistance Database

DCPETA: Decentralization, Citizen Participation, Empowerment, Transparency and Accountability

DFID: Department for International Development

DHS: Demographic and Health Survey

DIP: Decentralization Implementation Plan

DPAF: Development Partners Assessment Framework

DPCG: Development Partners Coordination Group

DPM: Development Partners Meeting

DS: Direct Support

EAC: East African Community

EASEA: East Africa Stock Exchange Association

EASRA: East African Securities and Regulatory Agencies

EC: European Commission

EDPRS: Economic Development and Poverty Reduction Strategy

EIA: Environment Impact Assessment

ELECTROGAZ: Electricity and Gas Company of Rwanda

EMIS: Education Management Information System

ENR: Environment and Natural Resources

EU: European Union

Fob: free on board

FSDP: Financial Sector Development program

FSDS: Financial Sector Development Secretariat

GBE: Government Business Entities

GDP: gross domestic product

GoR: Government of Rwanda

Ha: Hectare

HACCP: Hazard Analysis and Critical Control Points

HIMO: High intensive Labor Community Works

HIV: Human Immunodeficiency Virus 
HLI: Higher Learning Institutions

HMIS: health management information system

HR: Human Resource

HSSP: Health Sector Strategic Plan

ICT: Information and Communication Technology

IDA: International Development Association

IDM: Intelligent Data Manager

IDP: Integrated Development Program

IFC: International Finance Corporation

IFRS: International Financial Reporting Standards

ILPD: Institute of Law Practice and Development

IMCI: Integrated Management of Childhood Illnesses

IMF: International Monetary Fund

INSET: In-Service Training Centers

IOSCO: International Organization of Securities Commission

IPPIS: Integrated Personnel and Payroll Information System

ISAR: Institute of Scientific and Agricultural Research

IWG: Implementation Working Group

JAWP: Joint Annual Work Plan

JGA: Joint Governance Assessment

JHSR: Joint Health Sector Review

JRLO: Justice Reconciliation Law and Order

JSR: Joint Sector Review

Kcal: Kilo Calories

KCB: Kenya Commercial Bank

KIST: Kigali Institute of Science and Technology

Kwh: Kilowatt-hour

LLITN: Long Lasting Insecticide Treated Nets

LTRP: Land Tenure Regularization Program

MAGERWA: Magasins Généraux Du Rwanda

MDGS: Millennium Development Goals

MIGEPROF: Ministry of Gender

MINAFFET: Ministry of Foreign Affairs

MINALOC: Ministry of Local Government

MINECOFIN: Ministry of Finance and Economic Planning

MINICOM: Ministry of Commerce, Industry and Investment Promotion

MININFRA: Ministry of Infrastructure

MINIRENA: Ministry of Lands and Natural Resources

MINIYOUTH: Ministry of Youth

MoU : Memorandum of Understanding

MT: Metric Tones

MTEF: Medium Term Expenditure Framework

MW: Mega Watts

NAFA: National Forestry Authority

NAPA: National Program for Adaptation on Climate Change

NDIS: National Decentralization and Implementation Strategy

NEPAD: New Partnership for African Development

NGO: Non-Governmental Organization

NHRC: National Human Rights Council

NPC: National payment council

OAG: Office of the Auditor General

ODA: Official Development Assistance

OECD: Organization for Economic Cooperation and Development

OPBRC: Output and Performance Based Road Contracts

ORLT: Registrar of Land Titles

OTC: Over the Counter 
OVC: Orphans and Vulnerable Children

PBF: Performance based financing

PDCM: Paris Declaration Compliance Matrix

PEFA: Public Finance and Financial Accountability

PFM: Public Finance Management

PMTCT: Prevention of Mother to Child Transmission

PPP: Public Private Partnership

PW: Public Works

RADA: Rwanda Animal Development Authority

RAMA: La Rwandaise d'assurance maladie

RCRSA: Rwanda Commercial Registration Services Agency

RDB: Rwanda Development Board

REMA: Rwanda Environment Management Authority

RHESI: Rwanda Horticulture Export Standards Initiative

RICP: Rwanda Investment Climate Project

RIEPA: Rwanda Investment and Export Promotion Agency

RIG: Rwanda Investment Group

RITA: Rwanda Information and Technology Association

RMF: Road Maintenance Fund

ROTC: Rwanda

RPC: Rwanda Payment Card

RRA: Rwanda Revenue Authority

RTGS: Real Time Growth Settlement

RWF: Rwandan Francs

SADC: Southern Africa Development Community

SBS: Sector Budget Support

SFAR: Student Financing Agency for Rwanda

SGBV: Sexual and Gender Based Violence

SITI: Securities Industry Training Institute

SME: small and medium enterprise

SONARWA: Rwanda Insurance Company

SRM: Strategic Road Map

SSA: Sub Saharan Africa

STD: Sexually Transmitted Diseases

STI: Science, Technology and Innovation

SWAP: Sector Wide Approach

TC: Tronc Commun/ Ordinary level secondary

TDM: Teacher Development and Management

TOR: Terms of Reference

TVET: Technical Vocational Education and Training

UBPR: Union of Popular Bank in Rwanda

UN: United Nations

UNDP: United Nations Development Program

US: United States of America

USD: United States Dollar

VCT: Volunteer Counseling and Testing

VUP: Vision 2020 Umurenge Program

WSS: Water Supply System

YFC: Youth Friendly Centers 


\section{EXECUTIVE SUMMARY}

This report outlines the progress made in 2008 in implementation of the Economic Development and Poverty Reduction Strategy (EDPRS) based on the selected targets and policy actions defined in the EDPRS Results and Policy Matrix.

The EDPRS Results and Policy Matrix is structured on 3 major strategic objectives of; Increased economic growth, managing population growth rate and enhancing population development and Enhanced gains through good governance. The strategic objectives are in harmony with the 3 EDPRS clusters (Economic, Social and Governance) that were set up by the Rubavu retreat in February 2009.

Within each strategic objective there are a number of strategic outcomes, associated indicators and targets and policy actions required to achieve them. Each EDPRS sector contributes to the implementation of one or more strategic outcomes and indicators/targets, through its fulfilling of agreed policy actions.

The implementation report is drawn from reports provided by each sector after the completion of a Sector Performance Report approved by stakeholders in a Joint Sector Review and submitted to the Ministry of Finance (MINECOFIN). The Joint sector reviews provided a summary of key sector achievements, key challenges, key recommendation and information on 2008 budget execution.

\section{Economic Cluster}

This cluster covers the macro and financial sector alongside the economic sectors of agriculture, infrastructure (energy, transport, ICT and STI) private sector development as well as environment and natural resources management.

\section{Macro and financial sector}

The macro and financial sector was responsible for the achievement of 7 targets and only 1 was not met.

Growth performance in 2008 was higher than the projected rate of 8.5 percent at 11.2 percent. This growth was driven by a rebound in agriculture and continued buoyancy in the industry and services sectors which registered annual growth rates of $15,10.7$ and 7.9 percent respectively.

There was an expansion in credit to the private sector which grew to $14 \%$ percent of GDP by end-2008. Revenue in 2008 outperformed the projections by RWF 52 billion reflecting increased collection, higher inflation at an average of $15.4 \%$ and GDP growth as well as large one-off nontax revenue earnings.

In $2007 / 2008$, investment made up $17 \%$ of GDP, and in 2008/2009 is projected to make up $18 \%$, or RWF456 billion ( $\$ 791$ million). Increases in investment in recent years have been driven by a rapid increase in public construction expenditure, with private expenditure on machinery still suffering low growth

Broad Money increased moderately at $9.6 \%$ against an average increase of $25.7 \%$ (2005 to 2007) reflecting the increased absorption capacity of the economy and increase in capital component of 
public spending. Currency in circulation increased by $28 \%$ compared to $20 \%$ in 2007 as a consequence of high inflation.

The only target that was not met was the annual end year average inflation which reached double figures at $15.4 \%$ compared to a single digit target that was set. The acceleration in inflation arose from; high international commodity prices and domestic pressures from rising prices of food and non-alcoholic beverages. However, the inflation showed signs of stabilizing towards the end of the year with an increase of only $0.7 \%$ between September and December 2008.

Private sector; The Private sector was responsible for the achievement of 4 targets which were all achieved.

Rwanda has become "one of the most active reformers of business regulation worldwide this decade" according to the World Bank. Rwanda is ranked 139th in the World Bank Doing Business rankings and is now ranked in the top-third of sub-Saharan African (SSA) countries. The score on investor perceptions of investment climate showed an average rating of $79 \%$ all reflecting improvements through the doing business reforms.

Revenue from strategic exports obtained was USD 185 million exceeding the target of USD 163 million and revenue from tourism activities also increased to USD 208 million from a target of USD 56 million.

Infrastructure; the infrastructure sector was responsible for the achievement of 6 targets and all were achieved except 1 due to lack of reporting.

Power production has increased and stabilized since the severe power shortages in 2004 and total installed capacity has increased from $45 \mathrm{MW}$ in 2006 to $74.5 \mathrm{MW}$ in 2008 and 56MW generation capacity, exceeding the 2008 target of 50MW. The target for the number of electricity connections in 2008 was 100,000 connections and the performance realized was of 110,000 connections from a baseline of 91,332 in 2006.

The EDPRS target for the percentage of classified national road network in good condition was to move from $11 \%$ in 2006 to $16 \%$ in 2008 , this was exceeded with an actual performance of $18 \%$. On the percentage of classified district road network in good condition, the target was to move from $15 \%$ (2006) to $22 \%$ (2008), however, following the decentralization of the budget for district road maintenance to local governments, no reports were submitted by districts on this and as such no quality information could be reported against this target.

ICT composite coverage network is now at $90 \%$ and the number of mobile phone users has now reached 1,322,637. A total of $77 \mathrm{~km}$ of fibre optic enabling a Wireless Broadband network for Kigali city and its suburbs has been laid.

Agriculture; the sector was responsible for achievement of 6 indicators, 2 were not due to be assessed and 4 were achieved.

There have been significant increases of $16.4 \%$ and $20.3 \%$ in food and export crop production respectively, which can be attributed to GoR's work in the areas of crop intensification, disease prevention and assistance to producers of traditional and non-traditional export crops, as well as 
good rains. These production increases have buffered Rwanda against the global food crisis and the associated rise in food prices.

Another key food security and export crop indicator for the sector was the production in MT of key food security and export crops which targeted an increase by 30\% between 2006 and 2012 . Crop production targets were exceeded for all key food security crops in 2008.

Environment; the sector was responsible for the achievement of 5 targets; 3 were fully achieved and 2 were not met.

Currently, the surface land area coved by forest and agro-forest increased from $20,2 \%$ to $21 \%$ (plantation of 31.327 .410 trees on $19579 \mathrm{ha}$ ) and the area of land protected to maintain biological diversity exceeded the target of $8.4 \%$ by an actual performance of $8.5 \%$. The percentage of water resources complying with water quality standards was attained at $30 \%$.

The targets which were not met both relate to land; the percentage of area of privately owned land held under written title was $1.26 \%$ compared to a target of $3 \%$ and the proportion of issued land titles owned by Women was $0.02 \%$ compared to a target of $2 \%$.

\section{Social cluster}

This cluster covers Education, Health, Social Protection, Youth and Water and Sanitation.

The health sector was responsible for the achievement of 12 targets which were achieved and 1 was not fully met.

The percentage of women using modern contraceptives increased from $10 \%$ in 2006 to $27 \%$ (mini DHS 2007/2008) exceeding the target of 25\%. The percentage of children fully immunized increased from $75 \%$ in 2006 to $80.4 \%$ (HMIS 2008).

On the indicator measuring the percentage of children using Long Lasting Insecticide Treated Nets (LLITN), significant progress was made, however, the target of $65 \%$ was not fully realized with the mini-DHS (2007/8) reporting a score of $60 \%$ from a baseline of $16 \%$ in 2006 . The percentage of assisted births in an accredited facility exceeded the target of $35 \%$ with a performance of $62.8 \%$ (HMIS 2008) coming from a baseline of $28.2 \%$ (2006), this has also been included in all performance contracts of districts for 2009. The utilization rate of primary health care services also increased from $70 \%$ to $86 \%$ in advance of the $75 \%$ target that was set.

Regarding the systematic and early testing of HIV testing of children born to HIV mothers, there has been an increase from $86.7 \%$ in $2006 / 07$ to $87.3 \%$ in 2008, however, the target for per capita allocation to Performance-Based Financing (PBF) was not met fully with a realization of $\$ 1.40$ compared to a target of $\$ 1.45$ in 2008 .

Water and Sanitation; the sector was responsible for the achievement of 2 targets which were both fully achieved.

Rwanda has made significant progress towards achieving the Millennium Development Goals (MDGs) 2015 targets and the Vision 2020 target of $100 \%$ access to water. In 2008, 73\% of 
population had access to clean drinking water and $45 \%$ had access to hygienic sanitation exceeding the target for drinking water and meeting the hygienic sanitation target fully.

In education, the sector was responsible for the achievement of 5 targets. 1 was not due to be assessed (non-survey year), 1 was fully achieved and 3 were not met.

Primary school net enrollment rate was $94.7 \%$ in 2007 for girls while $93.3 \%$ in 2008 . For boys, it was $96.8 \%$ in 2007 while in 2008 it was $95.1 \%$. There was an improvement in primary completion rate overall which was 52\% in 2007 while in 2008 it was 53\% however, it did not meet the target of $55 \%$. The ratio of girl students enrolled in higher education institution in science courses (public institutions) remains at 30\% and therefore did not meet the target of $32 \%$. Forced repetition of students in order to improve overall school performance has been highlighted as one of the reasons for the low performance in primary school completion rate.

The transition rate from basic education to upper secondary education fell behind the 2006 rate of $82 \%$ to $78.6 \%$ thereby failing to meet the target of $84 \%$. There is some baseline data problems associated with the indicators and a revision of targets is set to be made following the functioning of the Education management information system (EMIS) which should provide better quality information.

Social Protection; the sector was responsible for the achievement of 5 indicators; 3 were not due to be assessed due to no targets set (baseline studies being conducted) and 2 were fully achieved.

The percentage of households in the bottom two categories of extreme poverty according to Ubudehe classification were $28.6 \%$ (VUP survey 2007), the progress however, could not be measured since the next survey is scheduled for mid-2009. Of the households eligible for support, the percentage granted public works was targeted at $35 \%$ which was fully realized, whilst the number of vulnerable households accessing credit and savings facilities exceeded the target of 6,390 to register 17,626 . The average social protection income provided through district support budgets to poor and vulnerable groups amounted to RWF $33,730,605^{1 .}$

The key challenges are the Monitoring of graduation from livelihood enhancement schemes because graduation is not well defined. There is need to improve the coordination at both national and local levels as well as greater information sharing.

Youth; the sector did not have any quantitative indicators/targets to report against, however, it was responsible for the implementation of a number of policy actions which were all fully implemented. The target of supporting the transformation of fifty (50) youth associations into cooperatives was surpassed and in total, 61 associations were supported. Youth in all districts were sensitized to become members of COOJAD (a Youth Cooperative Bank for Self employment and Development.)

\section{Governance Cluster}

The governance cluster brings together four sector working groups related to the areas of Public Financial Management (PFM), Justice, Reconciliation, Law and Order (JRLO), Decentralization,

1 This is the average amount received per district. 
Community Participation, Empowerment, Transparency and Accountability (DCPETA), and Capacity Building and Employment Promotion (CBEP).

\section{Public Finance Management;}

The sector was responsible for the achievement of 7 targets. 3 were not due to be assessed at the end of 2008 (non survey year) and 4 were fully achieved.

A new Public Financial Management Reform Strategy 2008-2012 was presented in September 2008 together with a detailed Action Plan for 2009-10 and approved by Cabinet in December 2008. Seven PFM indicators and related policy actions were subsequently incorporated in the EDPRS.

Work on improving the Medium Term Expenditure Framework (MTEF) and budget classification has been carried out as well as the technical and functional requirements, for the development of the Integrated Personnel and Payroll Information System (IPPIS).

Government agencies representing 30\% of all budget agencies have submitted internal audit report, hence, the $25 \%$ target has been met, and the Office of the Auditor General (OAG) has audited $60 \%$ of the reported government expenditure, exceeding the $50 \%$ target set for the year. As regards procurement processes, $86 \%$ of the tenders have been competitively or justifiably awarded exceeding, the $75 \%$ target for 2008 .

Justice, Reconciliation, Law and Order (JRLO); The sector was responsible for the implementation of 6 targets with 5 performance targets met, and one not met fully.

With regards to the case backlog, both performance targets were exceeded, with the Prosecution submitting 4861 backlog cases to the courts, which judged 7965 backlog cases. The percentage of corruption cases treated was $75 \%$ exceeding the $60 \%$ target Prison overcrowding was reduced from $140 \%$ of jail capacity in $2006 / 07$ to $130 \%$ in 2008 , exceeding the $135 \%$ target that was set. There was also a reduction in the crime rate by $15 \%$ achieving the set target.

The indicator not met was the proportion of human rights reports timely submitted due to untimely submission.

Decentralization, Citizen Participation Empowerment, Transparency and Accountability; the sector was responsible for the achievement of 4 targets, 3 were not due to be assessed and 1 was fully met and exceeded.

$67 \%$ of districts achieved a minimum $80 \%$ of their service delivery targets (against a target of $62 \%$ ). Parliamentary elections were organized and concluded successfully and Civil Society Organizations mobilized themselves to monitor and observe the elections, voter turn out was high throughout the country. From the elections Rwanda has a $56.25 \%$ level of representation of female members of parliament, this being the highest in the world.

The challenge in this sector is the establishing and strengthening of partnerships in data collection and commissioning of surveys as well as establishing clear coordination and communication structure for partners and Government concerning the scope of the sector. 
Capacity building and employment promotion; the sector was responsible for the achievement of 2 targets; both were not due to be assessed due to lack of baselines for target setting.

The percentage of budget agencies which achieve a minimum of $80 \%$ of their action plans was $20 \%$ and targets have been set for improving in ensuing years. The number of new non farm jobs created was not assessed. Policy actions implemented include the completion of all planned functional reviews for 17 institutions. The Districts Capacity Building Needs Assessment was planned and all 30 districts were audited.

The key challenges in this sector are; the funds mobilization for the internship program and the urgent need for macro level data on employment.

\section{Integration of cross-cutting issues}

Environment; important common tools have been applied such as the EIA (environment impact assessment) in order to mitigate impact of different interventions on environment. The use of Environment impact assessment tools trough project was institutionalized by publishing EIA sectoral guidelines for fuel stations, slaughter-houses and tanneries, and 65 projects out of 109 submitted for certification received certificates by Rwanda Environment Management Authority

Gender; Guidelines for gender-based budgeting have been developed by the MINECOFIN and subsequent training prepared for 2010/2011 budget preparation. A national gender profile was established as a baseline to guide the planning process in all sectors. By the law $\mathrm{N}^{\circ}$ 51/2007 of 20/09/2007, a Gender Monitoring Office in charge of monitoring the quality of gender mainstreaming in various institutions was created.

HIV/AIDS; At the district level, all the 30 districts have been supported to incorporate HIV AIDS as appropriate into the district integrated planning tools such as Medium Term Expenditure Frameworks (MTEF) and Annual Work Plans (AWP).

\section{Social inclusion}

Solidarity camp for street children was carried out and many of them were oriented to primary schools and 120 retained in their families. In addition to this, the $3^{\text {rd }}$ and $4^{\text {th }}$ report on the implementation of the convention related to child rights was elaborated.

\section{Conclusion}

In general implementation of the EDPRS in positive: $81 \%$ of the targets set were met or exceeded, with the strongest performance in the Governance cluster which had an overall implementation of $91 \%$ of targets, whilst the economic and social cluster achieved $78 \%$ and $75 \%$ respectively. With regard to the performance in implementing policy actions, overall performance was good with $80 \%$ achieved, $16 \%$ insufficiently achieved and $4 \%$ not met.

Key challenges faced are in mitigating the impact of the global financial crisis, controlling inflation, strengthening of monitoring and evaluation systems and ensuring completion of policy actions insufficiently achieved. 


\section{INTRODUCTION}

1.1 Background: In 2008, the Government of Rwanda (GoR) embarked on the implementation of the second generation poverty reduction strategy termed the 'Economic Development and Poverty Reduction Strategy' (EDPRS). The EDPRS covering the period 2008-2012 sets the country's developmental objectives, priorities and policies for the next five years through three flagship programs i) Growth for Jobs and Exports; (ii) Governance; (iii) Vision 2020 Umurenge, that aims to reduce inequality and poverty . The EDPRS is fully supported by country level stakeholders, including development partners and assigns high priority to accelerating private sector-led growth.

The Sustainable Growth for Jobs and Exports flagship aims to boost growth by enhancing competitiveness, private sector investment and innovation, agricultural productivity, exports, and information and communication technology (ICT) competences. The second flagship, Vision 2020 Umurenge, aims to address extreme poverty and vulnerability, particularly in the rural areas. Finally, the Governance flagship focuses on: maintenance of peace and security; improved relations with all countries; promotion of national unity and reconciliation; justice, human rights and the rule of law; and decentralization, public financial management, service delivery, and fighting corruption.

Taken together, the EDPRS' three flagships programmes - Sustainable Growth for Jobs and Exports; Vision 2020 Umurenge (a decentralized social protection scheme); and Governance propose a comprehensive agenda of economic growth favoring the poor that is underpinned by good governance, and that provide a roadmap for Rwanda to achieve the Millennium Development Goals (MDGs) by 2015.

1.2 Monitoring of the EDPRS: Monitoring of the EDPRS implementation was carried out through the institutional framework of the EDPRS and the integrated monitoring and evaluation framework. The integrated monitoring and evaluation framework consists of 3 instruments namely; the EDPRS Results and Policy Matrix, the Common Performance Assessment Framework (CPAF) and the Development Partners Assessment Framework (DPAF).

The National EDPRS Results and Policy Matrix are used by domestic stakeholders to track progress towards EDPRS goals. The CPAF, selected by development partners in consultation with GoR as a subset of the National Results and Policy Matrix, provides the basis for development partners to hold the GoR accountable for the use of development assistance. In this way, the perspectives of Rwandan policy makers and donors have been aligned and the transactions costs of monitoring reduced.

Mutual accountability between the GoR and development partners is completed by a mechanism established by both parties to assess donor performance. The Donor Performance Assessment Matrix which is based on Paris Declaration Compliance Matrix (PDCM) is used to provide such a mechanism. The matrix facilitates the monitoring of efforts and outcomes against donor commitments, and other commitments relating to the volume and quality of aid provided. It applies to all providers of Official Development Assistance (ODA) to Rwanda. 
The institutional framework for implementing the EDPRS was restructured during the Rubavu retreat of Government to group the different sector working groups according to 3 clusters of Economic, Social and Governance Clusters for easy coordination and harmonization.

The analysis of Annual performance is based on reports provided by each sector after the completion of a Sector Performance Report that was subsequently presented and approved by stakeholders in a Joint Sector Review and submitted to the Ministry of Finance (MINECOFIN) Central Monitoring and Evaluation Secretariat ${ }^{2}$. The sector performance provided a summary of key sector achievements, key challenges, key recommendation and budget execution information.

This report summarises the progress on implementation of the Economic Development and Poverty Reduction Strategy (EDPRS) in 2008. It focuses on the 2008 indicators, subsequent targets and policy actions appearing in the EDPRS Results and Policy Matrix ${ }^{3} /$ Common Performance Assessment Framework (CPAF). A user-friendly summary of progress is presented in annex to this report showing a traffic-light scoring of targets.

The scoring of targets was done using an agreed methodology as follows;

Red (R) Not Achieved; less than 50\% of progress towards target from baseline or absence of reporting where metadata indicates it should be available, Indicates that the target is unlikely to be achieved even with concerted action; either because of internal mismanagement or outside factors;

Yellow (Y) Insufficient implementation - at least $50 \%$ to $89 \%$ progress towards target from baseline, indicates that the target has not been achieved to a satisfactory level; but that it is still possible to achieve the target if appropriate actions are taken

Green (G) Achieved - at least $90 \%$ of progress towards target from baseline; indicates that either the activity has been completed satisfactorily or will be completed within the timeframe.

NA where indicator is not due for assessment/ measurement or target was not set

This report is structured as follows; chapter 1 is the introduction, chapter 2 covers the progress made in the economic cluster, chapter 3 shows progress in the social cluster and Chapter 4 shows progress in the governance cluster. Chapter 5 then highlights mainstreaming of cross cutting issues whilst chapter 6 deals with aid harmonization and coordination. Chapter 7 provides the conclusion, which is followed by annexes of; the traffic light report on the EDPRS Results and Policy matrix and CPAF and the Terms of Reference on Joint Sector Reviews.

\footnotetext{
${ }^{2}$ Terms of reference for the Joint Sector Reviews are annexed at the end of this report

${ }^{3}$ The impact on poverty reduction however, can only be measured during the third household living conditions survey (EICV III) in 2012.
} 


\section{ECONOMIC CLUSTER}

This cluster covers the macro and financial sector alongside the economic sectors of agriculture, infrastructure (energy, transport, ICT and STI) private sector development as well as environment and natural resources management.

\subsection{Macro and financial sector}

To achieve poverty reduction and increase economic growth, the GoR has set a number of macro economic objectives in the EDPRS period (2008-2012):

- Achieve an average annual GDP growth rate of $8.1 \%$ from $6.5 \%$;

- Increase exports at $15 \%$ per annum;

- Increase investment rate from $15 \%$ of GDP to $23 \%$ by 2012 ;

○ Reduce the population living in poverty from $57 \%$ to $46 \%$ and those living in extreme poverty from $37 \%$ to $24 \%$.

○ Increase public expenditure by $9.0 \%$ per annum between 2008 and 2012 .

The macro and financial sector was responsible for the achievement of 7 targets and only 1 was not met.

Growth performance in 2008 was higher than the projected rate of 8.5 percent at 11.2 percent. This growth was driven by a rebound in agriculture and continued buoyancy in the industry and services sectors which registered annual growth rates of 15, 10.7 and 7.9 percent respectively. The strong recovery in agriculture was driven by better rains and government actions to improve productivity: i) the ongoing expansion of the crop intensification program; ii) increased fertilizer use; iii) distribution of better quality seeds; ongoing irrigation investments ; and v) greater use of erosion control measures, including terracing. In addition, government-funded storage facilities are also improving the management of harvest stocks.

However, headline inflation increased well above the single digit target range in 2008, reaching 22.3 per cent (year-on-year) in December, compared to 6.6 percent in December 2007 and an end year average of $15.4 \%$. The acceleration in inflation arose from: high international commodity prices and domestic pressures from rising prices of food and non-alcoholic beverages.

In response, Government implemented some policies to rein in inflationary pressures, including: (i) control of fuel pump prices; (ii) tightening of monetary policy to reduce broad money growth from 30 to around 11 percent; and (iii) tightening of fiscal policy by reducing planned expenditure. Despite these measures, average annual inflation climbed to 15.4 percent in December 2008, having remained in the single digit bracket up to July 2008. Government also allowed a 5 percent depreciation of the Rwandan franc against the U.S. dollar from mid-2008, partly mitigating the real appreciation pressures.

Net domestic financing exceeded its target at $-3.3 \%$ compared to a target of less than $0.5 \%$. Insurance coverage as a percentage of GDP (excluding mutuelles de santé) has been maintained at less than $1 \%$. Net present value of external debt (\% of export earnings) was also maintained at 45 in line with target of less than 150. Credit to the private sector as a percentage of GDP increased from $10 \%$ in 2006 to $14 \%$ in 2008 exceeding the target of $11.4 \%$ that was set. 
On the fiscal side, spending remained expansionary and revenue outperformed projections. Expansion in spending over the year was driven by domestic capital expenditure, which grew by 44 percent, in line with the priorities of the EDPRS to fund priority agriculture and infrastructure development projects. The GoR increased its expenditure and net lending in 2008 to estimated levels of 26.7 percent of GDP, financed by increased revenues from domestic sources and international grants.

On the revenue side, 2008 outperformed the projections by RWF 52 billion reflecting increased collection, higher inflation and GDP growth as well as large one-off non-tax revenue earnings ${ }^{4}$. Taxation from consumption and international trade also increased substantially reflecting increased monetization of the economy and recent reforms in customs processing. The above factors resulted in an increase in the revenue to GDP ratio from $13.6 \%$ in 2007 to $15.6 \%$ in 2008. Subtracting out the increases from the non-tax revenue leads to an increase to $14.3 \%$ in 2008 .

On the external sector, import growth exceeded the increase in exports, leading to a widening of the trade balance in 2008: Exports increased by 25.4 percent (f.o.b., US Dollar terms) compared to 2007 , driven by traditional products such as tea and coffee which have grown strongly due to good weather conditions, high prices and a rebound effect for coffee from last year. Minerals also saw important growth. Growing imports of capital goods as well as intermediate goods for infrastructure projects in line with higher public capital spending were the main contributors to the large increase in imports (44 percent in US Dollar terms, f.o.b.). This led to a larger current account deficit (including official transfers), up from 4.9 percent (in 2007) to 6 percent of GDP in 2008 .

Broad Money increased moderately at 9.6\% against an average increase of $25.7 \%$ (2005 to 2007) reflecting the increased absorption capacity of the economy and increase in capital component of public spending. Currency in circulation increased by $28 \%$ compared to $20 \%$ in 2007 as a consequence of high inflation.

Key policy achievements in this area were; the preparation of the 2009 mini-budget in line with EDPRS priorities and the medium term macro framework, the widening of the tax base evident in the surpassing of projections of revenue collection. Importantly also a comprehensive compliance system to identify risks of non-compliance was developed including the SIGTAS computer system to enhance information analysis by revenue authorities.

In order to streamline the proper management of taxpayers and improving taxpayer compliance level, a study on the implementation of the block management system was commenced purposely to bring more traders into the tax net. The block management system was designed to manage the tax affairs of small, medium and large enterprises by demarcating the areas in which they conduct business into sizable and manageable blocks.

The national insurance strategy was developed and an ensuing capacity building plan developed. Also the Microfinance law and strategy have been passed and a credit fund and capacity building fund established. A memorandum of Understanding was signed between national Bank of Rwanda (BNR) and the Ministry of Agriculture (MINAGRI) for the final phase of the rural

\footnotetext{
${ }^{4}$ In 2008, the domestic revenue collection reached 382bn RWF; an over-performance by 52 bn RWF from original projections. This was largely due to unexpected revenues from TIGO Licenses fees (33.4 Billion RWF), which drove up non-tax revenue collections to 52.3 billion RWF (approx. \$60 million), from 15.1 billion RWF in 2007, and against the target of 21 billion RWF.
} 
investment facility. The first version of the debt management strategy was produced and forwarded to Cabinet for approval.

\subsubsection{Capital Market Development}

The Rwanda OTC market was launched in 2008 and the Capital Market Advisory Council (CMAC) produced and published a Blue print that provides guidelines and rules for primary issuance and secondary market trading of both equities and bonds. The blue print formed the basis of operationalization of the Capital market in Rwanda.

CMAC signed an MOU to join the East African Securities and Regulatory Authorities (EASRA), a forum for the capital market regulators. EASRA is mandated by the EAC charter to make policy recommendations with the aim of harmonizing capital market rules for all the EAC partner states.

The National payment strategy and the National payment law were all established and approved by the Cabinet and the decree establishing National payment Council (NPC) was approved by the Cabinet, a draft of Ministerial order to put in place the NPC members is underway.

All commercial banks and BRD are now complying with BNR's capital and governance requirements, as well as International Financial Reporting Standards (IFRS). Over the same period of 2008, credit increased by $3.9 \%$ (from 279.9 billion to 321.1 billion) and deposits by $3.9 \%$ (from 363.2 billion to 377.3 billion). Non performing loans rate decreased dramatically from $14.3 \%$ in Dec 2007 to 8.8 in 2008 against the target of 5\%. The solvency of the whole banking sector was strengthened from $15.1 \%$ to $16.6 \%$.

The Microfinance law was passed by Parliament, and the related rules and instructions issued by BNR. Microfinance policy implementation strategy was approved, the capacity building fund and credit funds were created and now operational purposely to address two major issues in the area human resource capacity and financial resources. The association of microfinance institutions (AMIR) was established and strengthened, Cooperative law and SACCOs instructions are in place. The procurement to design a savings mobilization strategy was completed and the rural insurance study was accomplished.

\subsection{Private sector}

A vibrant private sector is central to Rwanda's ambitious targets in its Vision 2020, including halving the proportion of the population living in poverty, achieving an annual GDP growth of $8 \%$, reducing significantly the balance of payments deficit, and increasing the investment share of GDP from $18 \%$ in 2000 to $30 \%$ by 2020 .

The private sector was responsible for the achievement of 4 targets which were all achieved.

Rwanda had an ambitious target of $\$ 161$ million revenue from its strategic exports, classified at the time as tea, coffee, horticulture, hides \& skins, and minerals. Rwanda achieved \$185 million from these exports. Furthermore, the 2008 target for revenue from tourism was $\$ 56$ million. The figure achieved was $\$ 208$ million, although this was largely due to a new measurement methodology. 
Rwanda's total exports went up to \$262 million in 2008, close to a 50\% growth rate since 2007 . Efforts to expand exports underway include increasing fertilizer application for tea and coffee; diversifying the Rwandan tourism portfolio; and developing a service hub for mining services for the region.

Alongside the unprecedented turmoil in western equity and debt markets, a massive commodity boom has marked the past two years. Price hikes are now in steep reverse to the detriment of the primary commodities, especially minerals and cash crops, which dominate Rwanda's exports. Rwanda's coffee, tea and tourism strategies all focus on moving towards the more stable value added or specialty segments of their respective markets. They will need to do so to avoid falling revenues. Development of the smaller sectors of handcrafts, horticulture and hides and skins is promising, but not fast enough or large enough to deliver a significant level of export diversification.

Rwanda Development Board (RDB) is looking to diversify Rwanda's exports through its cluster selection exercise. This aims to identify alternative industries in which Rwanda has a chance of competing. Following a detailed analysis undertaken, six clusters have been selected for immediate action including three services clusters of mining services, niche tourism services and business process outsourcing; and three manufacturing clusters of silk textiles, fruits and vegetable processing and dairy. The next step will be to elaborate a strategic direction followed by detailed and clear action plans for the selected clusters

Furthermore Rwandan exporters of food products to the European Union (EU) face challenges in meeting the required standards in quality control of processed food products and packaging. The EU requires the use of Hazard Analysis and Critical Control Points (HACCP) as a minimum for the processing of food, but importers often apply private standards which are much more onerous. The Rwanda Bureau of Standards is working together with the Ministry of Agriculture (MINAGRI) to develop a one-stop-shop for export standards, including Sanitary and Phytosanitary testing, certificates of origin and other export standard support. However further work is needed to provide potential exporters with clearer information on the standards that they need to meet coupled with direct support for meeting those standards.

In $2007 / 2008$, investment made up $18 \%$ of GDP, and in 2008/2009 is projected to make up $17 \%$, or RWF456 billion ( $\$ 791$ million). Increases in investment in recent years have been driven by a rapid increase in public construction expenditure, with private expenditure on machinery still suffering low growth. RDB have been driving efforts to increase investment through its One Stop Centre for investors, this has reduced the number of procedures investors must go through to secure clearances and approvals.

Rwanda has steadily improved its business environment in a number of areas, increasing its rank across the World Bank's Doing Business indicators. As a result, the World Bank has called Rwanda "one of the most active reformers of business regulation worldwide this decade". Rwanda is ranked 139th in the World Bank Doing Business rankings and is now ranked in the top-third of sub-Saharan African (SSA) countries.

A Task Force coordinated by RDB and the Rwanda Investment Climate Project (RICP) led business reforms in 2008 focusing on registering property, dealing with licenses, starting a business and trading across borders. Under the RICP, commercial courts, the Rwanda 
Commercial Registration Services Agency (RCRSA) and the Office of the Registrar of Land Titles (ORLT) have been established. In the coming year, a Competition Authority should be in place as well as intellectual property rights legislation.

Other key reforms and policies implemented in the facilitation of ease of doing business include; the establishment of the Rwanda Commercial Registration Services Agency (RCRSA), the adoption of the bills on Companies Act, draft on secured transactions, draft on Contracts, draft on Business Registration, draft on Insolvency and the draft Bill on negotiation instruments. These bills have since been transmitted to Parliament.

The Revenue Authority Data Digital Exchange (RADDEX) system was installed and is now operational; this will enable improved data sharing with Uganda and Kenya. The Industrial Master Plan was finalized and validated at national level and the implementation of the levying of import taxes on FOB values will be implemented in July 2009.

\subsubsection{Budget execution}

Budget execution for 2008 came to $90 \%$. This represented a $96 \%$ execution of recurrent expenditure and $84 \%$ execution of development expenditure. The small shortfall in the development budget execution was predominantly within the budgets for feasibility studies and in the promotion of small and medium enterprises (SME) development. Of the recurrent expenditure shortfall, the largest shortfall was due to underutilization of the allocated travel funds for foreign visits. Finally, the shortfall in expenditure for the Rwanda Co-operative Agency was due to smaller than expected expenditure on wages, since the Agency is not yet fully operational.

\subsection{Infrastructure Sector}

Infrastructure development is a key element to the sustainability of economic growth. This sector is one of priority sectors of the EDPRS. The infrastructure sector was responsible for the achievement of 6 targets which were achieved and 1 was not met due to lack of reporting.

\subsubsection{Energy Sub Sector}

The sector has as objectives during the EDPRS; increasing access to electricity for enterprises and households, and ensuring security of power supply. The targets for 2012 are to increase number of electricity connected households and enterprises from 70,000 to 200,000 for the former and from $45 \mathrm{MW}$ to $50 \mathrm{MW}$ for the latter.

Of the 6 infrastructure targets, energy sub-sector was responsible for the achievement of 2 indicators which were all met.

Power production has increased and stabilized since the severe power shortages in 2004 and total installed capacity has increased from $45 \mathrm{MW}$ in 2006 to $74.5 \mathrm{MW}$ in 2008 and 56MW generation capacity, exceeding the 2008 target of 50MW. However, this has been achieved with significant reliance on imported diesel thermal generation. In addition to this, the methane gas pilot project was commissioned.

The target for the number of electricity connections in 2008 was 100,000 connections and the performance realized was of 110,000 connections (approximately $5 \%$ of households) from a 
baseline of 91,332 in 2006. This was largely attributed to the successful implementation of the electricity network expansion rollout program initiated by the Ministry of infrastructure (MININFRA).

150,000 carbon fluorescent lamps (CFL) have been distributed to improve energy economization and to reduce wastage.

Importantly, a number of policy actions have been implemented to further consolidate gains made in the sector; the national energy policy was completed and validated by sector stakeholders and submitted to Cabinet, a strategic note on electricity tariff, taxes and incentives was prepared and validated by stakeholders in December 2008. Furthermore, a Memorandum of Understanding (MoU) was signed between Government and Development Partners as a first output of a Sector Wide Approach (SWAP) in the energy sub-sector. The law on Electricity and Gas was approved by Cabinet and has been forwarded to Parliament for approval.

The $2^{\text {nd }}$ phase of the electricity Master Plan is also being developed as part of the clean water and electricity supply program, and the Ministry of infrastructure has signed a contract with 2 Independent power producers for generation of electricity as an attempt to engage more with the private sector. The energy policy was updated capturing issues of ensuring the security of provision and improvement of the quality of Energy services.

An important issue that is currently being addressed by the Government is increasing the national power generation capacity through construction of national Hydropower plants, namely Rukarara and Nyabarongo (total $37 \mathrm{MW}$ ), the signing of agreements with an independent power producer for $100 \mathrm{MW}$ from methane gas and ongoing negotiations for another $100 \mathrm{MW}$ of methane gas to power. 21 Micro hydro projects are under construction and will deliver power to rural communities.

Cost reflective tariffs will be introduced as soon as Rwanda can remove expensive rented diesel power from its generation mix. A study on Electricity effect of subsides and tariffs in electricity were finalized and the detailed tariff study will be undertaken in 2009 , a revision of the current tariff will then be developed.

A number of other important hydro power plants are being constructed over the course of 2008 and have been progressing well:

- 3 Micro Hydro power Stations of Keya, Nkora, Cyimbiri - (procurement completed);

- Eight (8) Micro Hydro Power Station=6.7 MW of Janja, Mukungwa 2, Rugezi, Gasha - (40\% of works completed);

- Construction Rukarara Hydro Power Station 9.5 MW - (50\% of works completed);

- 6 Micro Hydro Power Stations/NL (PPP)=1.5MW - (Mazimeru 50\% complete, Rwishya $80 \%$ complete, Gaseke $40 \%$ complete, Kavumu 20\% complete, while construction of Musarara, and Mpenge have not yet started);

- 3 Micro Hydro Power stations: Mukungwa 1, Gihira and Gisenyi - material inspection completed.

- Transmission and rehabilitation of hydro power network lines:

- Network line Micro Hydro power medium voltage (MV) -20km of Cyimbiri, Nkora, Pfunda /CTB - (contract under negotiation); 
- Electricity line MV-30KV Kigali-Kiyumba $51 \mathrm{~km}$ - (Studies for MV and Low voltage (LV) lines are approved and Expropriation is ongoing);

- Electricity line Gisenyi-Mukungwa - (Pre-feasibility study completed);

- Line MT 11KV Rambo-Camp Rubona, 5.3Km - (Construction works completed);

- Line MT 30Kv Rukarara-Kilinda 84Km - ( Tender documents prepared);

- Rehabilitation of Gikondo and urgent electrical materials of Electrogaz- (Completed);

- Electrification Umutara - $\left(1^{\text {st }}\right.$ phase completed $)$.

Diversification of energy service sources and supply security, a number of projects on diversification of Energy sources have been executed in 2008:

- Substitution of wood/coal: Household. Biogas (- 244 digesters constructed and operational, 310 , digesters under construction, - Masons and construction companies have been trained in bio-digester construction);

- Project to Substitute wood and wood coal: Improved stoves - (Biomass Energy Strategy approved);

- Rehabilitation of Bigogwe Petroleum storage (5000m3 works completed);

- Rehabilitation of Rwabuye Petroleum warehouse (3600m3 ) - (Contract signed);

- Construction of Kigali Petroleum storage (70.000m3) - (Studies ongoing);

- Rwanda Geothermal resource assessment - (Investigation on geological structure, geochemical and geophysical reconnaissance surveys completed);

- Access to Energy in Rural areas: Energy facility/CE - (Hydro: Feasibility studies have been conducted for 3 selected sites. Tender document will be launched by April 2009. Solar: 350 public institutions to be electrified have been selected, Solar systems have been designed and sized)

- Electrification with solar Energy - (Tender for 64 Health Centers under preparation, feasibility study for 35 under development),

\subsubsection{Budget Execution}

The overall execution of the 2008 budget for Energy sub sector was $97.2 \%$. This includes both Recurrent and Development Budget. However, the execution rate of the Development budget was $94.29 \%$ and recurrent budget was $100.2 \%$. The program for increase of access to electricity absorbs $95 \%$ of both Recurrent and Development sector budget. There was also significant success in the development partners financing round table discussions for national electricity access.

\subsubsection{Transport Sub Sector}

A key policy objective of the Government is to bring down the cost of transportation (both for passengers and goods) as a direct contribution to poverty reduction. Currently, transportation costs amount to more than $40 \%$ of the cost of any imported product.

Of the 6 infrastructure target, transport sub-sector was responsible for the achievement of 2 indicators; of which 1 was met and another was not met due to lack of reporting from districts on road rehabilitation works. 
The EDPRS target for the percentage of classified national road network in good condition was to move from $11 \%$ in 2006 to $16 \%$ in 2008, this was exceeded with an actual performance of $18 \%$. On the percentage of classified district road network in good condition, the target was to move from $15 \%$ (2006) to $22 \%$ (2008), however, following the decentralization of the budget for district road maintenance to local governments, no reports were submitted by districts on this and as such no information could be reported against this target.

Some key policy achievement include the periodic maintenance of $89 \mathrm{Km}$ National Earth Roads completed in excess of the target of $80 \mathrm{~km}$ of the $780 \mathrm{~km}$ network, the Transport Policy and Road Maintenance Strategy were also adopted by Cabinet and the $2^{\text {nd }}$ generation of Road maintenance fund is being implemented. Districts have signed Multi Annual (3 year) Output and Performance Based Road Contracts (OPBRC's) with at least 2 contractors since end of 2007 that are now being implemented. District road maintenance and decentralization strategy has been approved and is being implemented as part of the road maintenance strategy.

With respect to the development of Infrastructure for Opening up the Country (Mitigation of Land-Locked Status), a detailed design study of the new Bugesera Airport was started and is expected to be completed in early 2010. The Isaka - Dry Port Feasibility Study was equally commenced in 2008, while the feasibility study for the Isaka-Kigali/Keza-Gitega-Musongati Railway was completed by the end of 2008. A study on upgrading the Isaka-Dar es Salaam line is projected for 2009 (currently underway, co-ordinated by Tanzania).

Regarding the development and Maintenance of Road Transport Infrastructure, the rehabilitation works on a number of important roads has been progressing over the course of 2008: Ruhengeri Gisenyi (works about 70\% complete), Kigali - Ruhengeri (still in contracting phase); Gitarama Ngororero - Mukamira (works almost complete for section Gitarama - Ngororero; ), procurement process ongoing for works and supervision contract for the section Ngororero Mukamira, Kicukiro - Kirundo Road (works completed), Bugarama - Ruhwa (works to commence).

To ensure the Control of Transport Costs, as part of the East African Trade and Transportation Facilitation Project, the procurement of cargo scanners was noted to be on-course and a training course on the use of the equipment for RRA officials was conducted. The process to establish the Gatuna One Stop Border Post and negotiations on the establishment of an electronic single window are progressing well. In the domain of Regulation \& Road Safety, a Road Sign Survey was completed in the context of rehabilitation of road signs.

\subsubsection{Budget execution}

The overall execution of the 2008 budget was 99\%. This includes both Recurrent and Development Budget. The execution rate of only the Development budget was $102 \%$ an excess expenditure of $2 \%$. However, the execution rate of the program regarding the Institutional and Human Resource Capacity Building still very low 20\%. Under the EU supported project to rehabilitate the Gisenyi-Ruhengeri road, a financing gap of Euro 5.6million and RWF 2.8billion needs to be addressed. 


\subsubsection{ICT and Science, Technology and Innovation sub sector}

As an element in the Growth Flagship program, the science and technology sector contributes to the EDPRS goal of promoting science, technology and innovation for economic growth. But it is also supportive of other EDPRS goals and Flagship programs.

The ICT and STI sub sector was responsible for the achievement of 2 indicators which were all achieved.

Progress on targets for the sector indicators was good; ICT composite coverage network is now estimated at $90 \%$ and the number of mobile phone users has now reached 1,322,637.

On the development of a regulatory framework for ICT, a team has been assigned to draft laws and support development of STI in Rwanda until 2009. A total of $77 \mathrm{~km}$ of fibre optic enabling a Wireless Broadband network for Kigali city and its suburbs has been laid.

A new telecommunications company "RWANDATEL" has been licensed to take over from the deposed TERRACOM and is now operational with another operator 'TIGO' also licensed and set to begin operations. RWANDATEL and RWANDACELL have optimized their networks with 3G GSM Networks, 13 Licenses were issued including a Pay TV Operator STAR TV

In addition to this through the National Portal Project, 20 institutions have been equipped with teleconferencing capability, making it possible to conduct meeting remotely and effectively saving time and money. 55 websites have been developed to give web presence to government institutions

Furthermore, the GoR through its National ID project, a national population registry completed and stored in a master database. 3.2 Million Machine readable ID cards have been produced and currently being distributed; 2 million more cards are under production; a total of about 5.2 million eligible citizens will receive the new IDs. Driver's licence and smart ID card based on the same platform are being developed for distribution in 2009. All data required for issuing of electronic passports is in place, Immigration intends to move to electronic passports in the future.

The first and only mobile phone assembly in Rwanda was setup, and became operational in June 2008 (plant capacity is 20,000 units per month); locally assembled phones with a local language interface (Kinyarwanda) are now on the market.

12 telecenters have been completed \& operational in 12 districts to enable the gathering and distribution of information of all sorts \& widespread dissemination - detailed "best practice" \& market information.

The government in order to promote the one laptop per child program has ordered 100,000 laptops to be distributed in 2009 and the process of delivering is ongoing. NEPAD e-Schools program, a pilot rural schools program was launched in six schools throughout Rwanda in 2006 in partnership with CISCO and Microsoft. All institutions of Higher Learning have been connected to Internet 


\subsubsection{Budget execution}

The overall budget execution on ICT was almost $100 \%$ executed with an extra expenditure on infrastructure development due to the national backbone project. The management of RITA has been strengthen the implementation of NICI 2 plan as it is has been in its 3rd year of implementation and most of the project in the NICI 2 have all been initiated.

In STI, the budget was all not fully executed due to some challenges of the ministry being under staffed; this has been addressed in the new public service reform and it is expected that more staff are to be hired.

\subsection{Agriculture Sector}

The primary objective of the Agriculture and Animal Resources Sector is to contribute, in a sustainable manner, to the increase and diversification of household incomes, while ensuring food security for all the population.

The sector was responsible for achievement of 6 indicators, 2 were not due to be assessed and 4 were achieved.

Rwanda's agricultural sector registered an impressive growth rate of $15.0 \%$ in 2008 , contributing to the estimated national economic growth rate of $11.2 \%$. The increases of $16.4 \%$ and $20.3 \%$ in food and export crop production respectively can be attributed to GoR's work in the areas of crop intensification, disease prevention and assistance to producers of traditional and non-traditional export crops, as well as good rains.

Production in Season 2009A increased by $19 \%$ compared to 2008 A and by $41 \%$ compared to 2007A. These production increases have buffered Rwanda against the global food crisis and the associated rise in food prices. However, the combination of dependence on rain fed agriculture, low yields and fertilizer price increases means Rwanda remains susceptible to the possibility of food shortages. GoR will therefore retain its focus on staple crop production. To complement crop production, work continued in 2008 to increase livestock numbers and their productivity. Strong growth has been registered in both these areas.

These attainments have resulted in a per capita increase in income for the agricultural population of $5.2 \%$ between 2006 and 2007 and by $8.8 \%$ between 2007 and $2008^{5}$. Furthermore, the food balance sheet shows an availability of over $2,100 \mathrm{kcal}$ per capita per day for the 18 month period from January 2008 to June 2009 (compared to below 1,900 kcal per capita per day in 2007) . $^{6}$

In 2008 , a total of 12,920 ha of terraces (4,760 ha radical and 8,160 ha of progressive terraces) were constructed. Terracing is increasingly being carried out by districts. The target for 2008 was to increase the area of land protected from 40 to $45 \%$ of all land requiring erosion protection, however due to the lack of data available on the total area of land requiring terracing, it has not possible to report against this indicator.

Feasibility studies and detailed designs were commissioned and completed for 8 of the sites to be developed by the Land Husbandry, Water Management and Hillside Irrigation project. The

\footnotetext{
${ }^{5}$ Data source: MINECOFIN Macro Department. Figures for 2008 are estimates as agreed with IMF.

${ }^{6}$ Data source: Crop Assessment Report for Seasons 2008A, 2008B and 2009A, MINAGRI.
} 
procurement process for the feasibility studies and detailed designs for the remaining 24 sites is under way and will be completed by the end of the financial year Jan-June 2009.

On the indicator for the Proportion of farming households using improved methods, unfortunately, MINAGRI is unable to measure the use of fertilizer at the household level on an annual basis. However, despite a near-doubling of ex-Kigali fertilizer prices between 2007 and 2008 respectable levels of fertilizer imports were maintained, and only a slight drop in fertilizer imports, from just over 20,000 MT in 2007 to just over 17,000 MT in 2008 was reported. The level procured for food production remained constant.

Attempts are being made to involve the private sector in fertilizer distribution, e.g. through the voucher system and fertilizer auctions organized by the Government of Rwanda. The seed law is in place and its application decrees have been drafted.

Another key food security indicator for the sector was the production in MT of key food security and export crops which targeted an increase by 30\% between 2006 and 2012. Crop production targets were exceeded for all key food security crops in 2008, with 166,853 MT of maize, 82,025 MT of rice, and 67,869 MT of wheat having been produced in 2008. Tea production also exceeded targets with a total production of 83,830 MT. Production is on target for 2009 , as season 2009A saw a year-on-year increase of $1 \%$ and $12 \%$ of maize and rice output respectively. Despite a $17 \%$ decline in wheat production, $17,566 \mathrm{MT}$, more than half the wheat target, were harvested in January 2009.

Demonstration sites and farmer field schools have been established, as well as other projects and initiatives implemented through MINAGRI's agencies. ISAR is also trialling 24 corn hybrids on farmers' fields at altitude, assisting with the dissemination of up-to-date extension advice. A feasibility study was conducted for the Mushubi Tea Factory and the mobilization of funds for the construction of the factory is underway. The Nshili Kivu Tea Factory was constructed by a private company.

\subsubsection{Budget execution}

The sector budget execution for 2008 came to $106.43 \%$. The ordinary, counterpart and internally financed projects execution rates were respectively at $98.68 \%, 99.99 \%$ and $108.46 \%$. Major projects financed by internal fund in order of importance are: Priority Crops Intensification, One Cow per Family, Irrigation and Hillside Development, Commodity Chain Program and Veterinary Laboratory.

\subsection{Environment and natural resources management}

The overall objective of this Sector is to develop sustainable capacities to ensure that environment and natural resources are utilized and managed productively in support of sustainable national development. Strategic objectives to achieve this included: sustainable use and management of land resources; sustainable utilization of water resources; sustainable exploitation of mines, sustainable use of forestry resources as well as environmental services, among others.

The sector was responsible for the achievement of 5 targets; 3 were fully achieved and 2 were not met, of which 1 was due to non-availability of data. 
Aerial photography of $70 \%$ of the whole country has been accomplished. Processing of digital ortho-photos for Kigali City and Eastern Province is complete pending use in the production of base map and in land registration.

Land administration has been strengthened through establishment of national and local levels structures that include National Land Commission, City of Kigali Land Commission, Districts Land Commissions, District Land Bureaus, Sector Land Committees and Cells Land Committees. Systematic land registration has been initiated and Provisional titles for Gishwati and Eastern Province have been issued to ensure land redistribution. In terms of land use management, preparation of the National Land Use Master Plan which was aimed to be completed by 2012 is currently at $40 \%$.

In the area of regulation of national environmental management, 10 environmental regulations have been signed and enacted.

In forestry, Forestry law and forestry policy have been prepared and the national forestry inventory and mapping have been completed. Currently, the surface land area coved by forest and agro-forest increased from 20, 2\% to $21 \%$ (plantation of 31.327 .410 trees on 19579 ha). The use of Improved stoves (wood economic), particularly among rural households has seen tremendous growth. This has reduced wood consumption with implications for reducing soil erosion and promoting agricultural productivity. Forest management plans have been developed for 24 districts and National Forestry Authority (NAFA) has been established to ensure productivity of forestry resources.

In ecosystem rehabilitation, an inventory and categorization of wetlands has been validated. Terracing and tree planting activities are under way to protect Yanze watershed and so far 142 $\mathrm{km}$ of Yanze river borders are planted with Bamboo trees. In addition, $285 \mathrm{Km}$ of Lake Kivu shoreline in all 5 districts bordering the Lake have been rehabilitated; $75 \%$ of River banks have been protected within 10 metres and Master plan for Rugezi, Rweru- Mugesera, Akagera and Kamiranzovu watershed and 53 committees in charge of wetland protection have been established. In the area of pollution management, 82 new projects were compliant to EIA regulations. The EIA and public awareness programmes in REMA have undergone restructuring to provide enhanced support to private sector performance.

The water law has been adopted by the Parliament. 22 hydrological and limnology metric stations have been made operational. 16 tanks for rain water collection and 15 hill ponds to collect runoff were constructed in various district and 100 pumps and 20 kits availed to pump water from constructed tanks. 45 boreholes were drilled and there is ongoing monitoring of underground water quality in about 35 boreholes.

In the mining sector, institutional reorganization has facilitated significant reduction in processing time for issuance of licenses and presently it takes only ten days to issue a license. Annual investments for 2008 were 5.8 million USD in research and 5.4 million USD for exploitation way above the target of 2.4 million USD for both. Small scale miners have also registered remarkable growth with a total annual investment estimated at 900.000 USD. New Mining law and ministerial decrees one of which will streamline the taxes system to further stimulate investment have been developed. 


\subsubsection{Budget Execution}

The total budget execution for the sector in 2008 was $78 \%$ based on internal financing. External financing directly supported a total of 13 projects for the sector. Restructuring of water and sanitation sector and delayed disbursement of funds for the land programme account for the shortfall in the internal financing budget execution.

Table 1.1 Summary of Economic cluster performance at a glance

\begin{tabular}{|c|c|c|c|c|c|c|}
\hline $\begin{array}{c}\text { Total CPAF } \\
\text { Indicators/Targets }\end{array}$ & $\begin{array}{c}\text { Targets } \\
\text { Met or } \\
\text { Exceeded }\end{array}$ & $\begin{array}{c}\text { Targets } \\
\text { not Met }\end{array}$ & $\begin{array}{c}\text { Total } \\
\text { Policy } \\
\text { Actions }\end{array}$ & $\begin{array}{c}\text { Fully } \\
\text { Implemented }\end{array}$ & $\begin{array}{l}\text { Partially } \\
\text { Implemented }\end{array}$ & Not Met \\
\hline $\begin{array}{c}28 / \text { total targets } 23 \\
\text { (3 not set, 2 not due } \\
\text { for measurement) }\end{array}$ & $19(82 \%)$ & $\begin{array}{c}5(1 \mathrm{due} \\
\text { to non } \\
\text { availability } \\
\text { of data })\end{array}$ & 53 & $46(84 \%)$ & $5(9 \%)$ & $2(4 \%)$ \\
\hline
\end{tabular}

Table 1.2 Summary of Economic Cluster EDPRS Target Scores 2008

\begin{tabular}{|c|c|c|c|c|c|c|c|c|}
\hline Score Level & $\begin{array}{c}\text { Macro } \\
\& \\
\text { Financia } \\
\text { I }\end{array}$ & PSD & Agriculture & Energy & $\begin{array}{c}\text { Transp } \\
\text { ort }\end{array}$ & $\begin{array}{l}\text { ICT/S } \\
\text { TI }\end{array}$ & $\begin{array}{c}\text { Environme } \\
\text { nt \& } \\
\text { natural } \\
\text { resources }\end{array}$ & Total \\
\hline $\begin{array}{l}\text { Green (fully met/on- } \\
\text { track) }\end{array}$ & 5 & 4 & 4 & 2 & 1 & 0 & 3 & 19 \\
\hline Yellow (Partially met) & & 0 & 0 & 0 & 0 & 0 & 0 & $\mathbf{0}$ \\
\hline $\begin{array}{l}\text { Red (not met or not } \\
\text { assessed were CPAF } \\
\text { metadata indicates data } \\
\text { available to do the } \\
\text { assessment }\end{array}$ & 1 & 0 & 0 & 0 & 1 & 0 & 2 & 4 \\
\hline Not applicable & 1 & 0 & 2 & 0 & 0 & 2 & 0 & 5 \\
\hline
\end{tabular}




\section{Box 1: Economic Cluster Summary challenges and recommendations}

\section{The macro and financial sector}

- Increased pressure on the external sector as the Global Financial Crisis deepens giving rise to near-term risks for the balance of payments, particularly if this results in reduction in donor funding. Related to this is the need for investments to develop the mining, tourism and financial sectors to reduce their vulnerability to volatile international markets. The success of the agricultural sector is a key to buffer against the shocks of the financial crisis.

- Persistence of inflation arising from growth in the money supply (particularly as the monetization of the economy increases). There will be a need to continue with programs to ease food and fuel price increases coordinated closely with monetary policy.

- Increased challenge in maintaining domestic revenue as growth slows (due to the global crisis) and Rwanda joins the EAC leading to a reduction in tariffs. Given the current environment, domestic revenues are expected to drop to levels insufficient to cover recurrent spending by 2012 (as originally targeted under the EDPRS).

\section{Private sector}

- Limited private sector engagement in infrastructure sector development (partly arising from financial constraints).

- $\quad$ Rwanda faces the highest costs for exporting containers in the EAC region. The cost of transporting a container from Mombasa to Kigali amounts to $53 \%$ of its value.

- $\quad$ Firms face the highest electricity costs in the region at 24US cents/Kwh, compared to 11US cents/Kwh in Kenya.

- Despite significant progress in increasing the domestic savings rate since 2000, gross domestic savings remains at less than $5 \%$ of GDP. Currently only $14 \%$ of the adult population uses the formal banking system and only $22 \%$ have ever used it. Unless the gross domestic savings rate can be increased, investments will have to continue to be funded by the current account deficit or by official transfers.

\section{Infrastructure Sector}

- There is a need to step up the role of the private sector in power generation. This is however, countered by the fact that there is limited capacity of private sector as well.

- High electricity tariff limits is a challenge due to the adverse impact on real incomes of the poor, this leads to low demand for electricity and hinders economic development. The new tariff study is expected to propose new tariffs for different customer types.

- $\quad$ Lack of resource of road maintenance and sustainable financing of Road Maintenance Fund (RMF) to develop and maintain the transport infrastructure.

- Non-submission of reports by districts-the reason for this is not clear and a mechanism needs to be devised to tackle this issue. A comprehensive monitoring and evaluation system should be designed for this purpose.

\section{Agriculture sector}

- $\quad$ CIP needs to be evaluated in-depth, to determine which aspects of the program are most successful at increasing output, how it affects poverty reduction, how it can be expanded as well as its effectiveness given Rwanda's reliance on rain fed agriculture.

- The process of moving into commercial farming, including land consolidation and mechanization, pose considerable risks for smallholder farmers. MINAGRI must continue to explore ways in which risks can be reduced and, where appropriate, strengthen programmes to mitigate such risks.

- Due to the remarkable increases in agricultural production, many producers are now facing marketing problems. Improvement of management of cooperatives is integral to further market development as are development of food processing capacities and post harvest infrastructure.

- A number of challenges have been encountered in making inputs available to smallholders, particularly in involving the private sector in the distribution and/or production of fertilizer and improved seeds.

- The current global financial crisis is likely to negatively impact Rwanda's economy and the price of exports. Monitoring of prices of key export crops such as coffee and tea on the global market is important to mitigate the impact.

\section{Environment and natural resources}

- In land, the target for 2008 was to increase the area of privately owned land held under written titles from $1 \%$ to $3 \%$. However, the systematic registration and issuance of land titles were not done as planned because of land disputes and claims that delay registration process and absence of secondary legislation (wetlands and road reserves). Also, the process needed to be guided by a legal framework (approved strategic roadmap) and preceded by a digital ortho- photos processing. It is expected that the process will accelerate in 2009 , following the platform work done. 


\section{SOCIAL CLUSTER}

This cluster covers Education, Health, Social Protection, Youth and Water and Sanitation.

\subsection{Health sector}

The Government of Rwanda is committed to tackling illnesses related to poverty and ignorance and improving the health status of the population over the long term trough the EDPRS. It provides an overarching framework for Health Sector support over the next five years with the principal aim of reducing poverty and improving the health status of the population.

The objective of the health sector is to ensure, promote \& improve the health status of the Rwandan population by providing accessible quality preventative, curative, promotional \& rehabilitative services.

The sector was responsible for the achievement of 12 targets; of these 4 were not due to be assessed, 7 were fully achieved or exceeded and 1 was insufficiently achieved. The health sector has shown good performance in a number of key areas regarding maternal and infant health.

The percentage of women using modern contraceptives increased from $10 \%$ in 2006 to $27 \%$ (mini DHS 2007/8) with the Health Management Information System (HMIS) estimating coverage at $31.2 \%$, all of which exceed the target of $25 \%$. The percentage of children fully immunized increased from $75 \%$ in 2006 to $80.4 \%$ (HMIS 2008), slightly exceeding the 2008 target of $80 \%$ and this has benefited from all health facilities carrying out outreach services for immunization.

On the indicator measuring the percentage of children using Long Lasting Insecticide Treated Nets (LLITN), significant progress was made, however, the target of $65 \%$ was not fully realized with the mini-DHS (2007/8) reporting a score of $60 \%$ from a baseline of $16 \%$ in 2006 . The percentage of assisted births in an accredited facility exceeded the target of 35\% with a performance of $62.8 \%$ (HMIS 2008) coming from a baseline of $28.2 \%$ (2006), this has also been included in all performance contracts of districts for 2009.

The utilization rate of primary health care services also increased from $70 \%$ to $86 \%$ in advance of the $75 \%$ target that was set, however the target for per capita allocation to Performance-Based Financing (PBF) was not met fully with a realization of $\$ 1.40$ compared to a target of $\$ 1.45$ in 2008 and a baseline of $\$ 1.2$.

These achievements were attributed to both specific program interventions and efforts to strengthen the health system in general. Scaling up of emergency obstetrics and neonatal care, Focalized antenatal care and postnatal care services, and the full expansion of the integrated management of childhood illnesses (IMCI), Family planning and safe motherhood package in all district hospitals in many health centers are examples of successful interventions.

The formal integration of 60,000 health community workers (CHWs) in the health system was another landmark achievement in bringing services closer to the population. Malaria and other 
childhood killers and ailments are being captured early, in addition community distribution of contraceptive commodities and maternal death audits have commenced.

Reducing financial barriers to improve access to health care through the community based health insurance schemes, increased motivation of health workers to improve quality and utilization of health services through the Performance Based Contracting Scheme, and improved geographical access through the construction, equipping and renovation of health facilities have all strengthened access to quality services and the health system.

Guidelines have also been developed for the treatment of diarrhea and training conducted in 4 districts; this is set to be replicated in all districts of the country. A national policy on provision of initiate testing has been developed and scale up is planned for 2009.

Regarding the systematic and early testing of HIV testing of children born to HIV mothers, there has been an increase from $86.7 \%$ in $2006 / 07$ to $87.3 \%$ in 2008 . Condom access points have been intensified and a tool to facilitate dialogue for parents and children regarding use of condoms has been developed, this is anticipated to reduce the barriers in communicating on sexual matters hence reducing risks of increasing spread of sexually transmitted diseases (STDs). Revision of treatment and care protocols has been completed and is to be communicated through a Ministerial order.

2008 Policy actions for the health sector that were achieved include; the publishing of the Population and family planning promotion policy including IEC strategy, the conducting of outreach services for immunization by all health centers exceeding the $10 \%$ target set and the inclusion of assisted delivery in 'Imihigo' of districts and their action plans which was $80 \%$ compared to target of $35 \%$.

Others achieved were; the development and approval of a Community health policy implementation plan and budget, including partners' programs, the approval of a community based PBF strategy and the approval of a Credible health sector MTEF that supports community health and nutrition policy reforms including community PBF, CHW training and incentive strategy for maternal health. Furthermore, health facilities received about $\$ 1.40$ per capita per year in PBF including assisted delivery exceeding the policy action target of \$1.20.

Policy actions not fully achieved but with significant progress are; the increase of the Youth Friendly Centers compared to all facilities, this was realized at one-third of the target which was $35 \%$, the publication of a report on financial access to health care in Rwanda (only a draft was prepared) and the approval of a Community health policy implementation plan and budget, including partners' programs which is scheduled to be completed in June 2009. The policy action to include use of bed nets by children less than 5 as performance indicator in district performance contracts was only $20 \%$ achieved.

In order to have a clearer overview of the activities by all key players in the health sector, the sector embarked on developing their first Joint Annual Work Plan (JAWP) in 2008. The process was informative and helped to develop the JAWP 2009. 


\subsubsection{Budget execution}

Regarding budget execution, all budget lines have an outturn of $79 \%$ or more, except geographical access, which had an outturn of $35 \%$. The low performance of geographical access is due to the Saudi Loan and DFID SBS grant received in quarter 3 of 2008.

\subsection{Water and sanitation sector}

The Water and Sanitation Sector aims to ensure sustainable and integrated water resources management and development (IWRM\&D) for multipurpose use (energy production, irrigation, navigability) including increased access to safe water and sanitation services.

The sector was responsible for the achievement of 2 targets which were both fully achieved.

Rwanda has made significant progress towards achieving the Millennium Development Goals (MDGs) 2015 targets and the Vision 2020 target of 100\% access to water. In 2008, 73\% (6.9 million) of population had access to safe water supply and (45\%), 4.3 million had access to hygienic sanitation from the $64 \%$ and $38 \%$ baselines of 2006 respectively. The annual target for 2008 access to safe drinking water was $70 \%$ which was surpassed and for hygienic sanitation systems was $45 \%$ which was met.

In the area of Strengthening of institutional capacities, legal and regulatory framework, the following have been achieved; a Draft of the updated Water Sanitation and Supply (WSS) sector policy which takes into account new institutional framework involving the establishment of water and sanitation board is ready and will be completed in October, 2009. Also a draft final report on monitoring and evaluation system and national inventory of water supply and sanitation infrastructures was prepared and will be concluded in June, 2009

Importantly also a harmonized plan of ECOSAN latrines was developed in Dec, 2008 and guidelines on ECOSAN utilization were developed as well. A Draft report has been prepared on sector financing mechanism to streamline and harmonize the flow of resources for the rural WSS and the final report will be completed in July, 2009

The strong achievement in meeting and exceeding the water and sanitation is as a result of improved sector coordination and harmonization. It is expected, the updated Water and Sanitation policy should provide more impetus to the ongoing drive for coordination and harmonization of programs directed to rural Water and Sanitation.

A number of district water supply master plans have been prepared in 3 districts of Ngororero, Gicumbi and Gakenke, compared to a target of 5 for 2008. $651.5 \mathrm{KM}$ of new water supply systems were constructed against a target of $517 \mathrm{~km}$. 53 rain water harvesting tanks were also set up in 8 districts as part of the program to promote rain-water harvesting techniques to increase water usage and minimize wastage. 70 boreholes were constructed against a target of 150 for the year.

Construction of sanitation facilities in pilot imidugudu, public places including schools, roads, health centers, markets, and district headquarters, in Western and Southern provinces has continued to make steady progress with 92Public latrines constructed with 543 doors. This has no doubt contributed to the increase in sanitation coverage rates. 


\subsubsection{Budget execution}

The overall execution of the 2008 budget was $102.6 \%$. This includes both recurrent budget (35\%) and Development Budget (103\%). The budget execution rate of the ELECTROGAZ on the Water department is $87 \%$ with a budget of development below half $49 \%$.

\subsection{Education Sector}

The GoR considers Education as a fundamental human right and it strives to ensure all Rwandese access quality, equitable and effective education.

Education sector was responsible for the achievement of 5 targets. 1 was not due to be assessed, 1 was fully achieved and 3 were not met.

In 2008, a number of significant achievements were made in the education sector.

Policies on Integrated Technical, Vocational Education and Training (TVET), Teacher Development and Management (TDM), Girls' Education, Special Needs Education and Higher Education were completed and these are expected to strengthen the backbone of education management in different areas pertaining to the respective policies mentioned.

A number of other policies are also in the drafting phase, these include; Literacy Policy, School Health Policy, Early Childhood Development (ECD) Policy, and ICT in Education Policy.

3.3.1 Primary education currently shows;

- Gross Enrollment rate was $151.9 \%$ in 2007 while in 2008 it was $127.9 \%$. This indicates that the over-age students have reduced and more children of appropriate school going age are now attending school.

- Net enrollment rate was $94.7 \%$ in 2007 for girls while $93.3 \%$ in 2008 . For boys, it was $96.8 \%$ in 2007 while in 2008 it was $95.1 \%$.

There was an improvement in Completion Rate Overall which was 52\% in 2007 while in 2008 it was $53 \%$ however, it did not meet the target of $55 \%$, and forced repetition of pupils to increase school performance is one of the reasons for this in some districts. Primary school pupil to qualified teacher ratio was one teacher to 74 pupils in 2007, while in 2008 it dropped to one teacher to 66 pupils which is good progress exceeding the target for 2008 of one teacher to 72 pupils.

Transition from basic education (TC) to upper secondary education did not make any progress falling behind the 2006 rate of $82 \%$ and falling way behind the target of $84 \%$ for 2008 . This can be attributed mainly to the surge in enrollment rates at primary level since the introduction of Universal Primary Education (UPE) which has led to increased enrollment and completion rates in the past without a similar expansion in the secondary schools.

There was no update on the percentage of employers satisfied with the performance of TVET graduates as this indicator was due to be assessed through a survey in 2009, the previous figure was at $8 \%$ in 2006 . The number of female students enrolled in science courses has been maintained at $30 \%$ although the target was $32 \%$. 
There were significant achievements in the capacity building such as; 34,000 teachers trained in civic education, 8 trainers and facilitators from TSC to facilitate the training in all districts; trained 88 English teachers who will train others; 77 pre-primary teachers trained in nursery teaching methodology; 4770 primary teachers trained in English, Completed the training of approximately 50 schools on the school-based EMIS solution.

MINEDUC core staffs were trained on the usage of the EMIS system; 1,650 computers distributed among different primary schools, 4,484,428 text books in different disciplines were procured and distributed and 2,315 classrooms were constructed.

\subsubsection{Secondary Education}

198,792 text books in different disciplines were purchased and different teachers' guide as well. Biology syllabus for Math Physics option was revised and translated in English, draft Physics teacher's guide for Math-Physics option was produced, Kinyarwanda, French and psychology student's textbooks and teacher's guide were revised. The Teacher's guide for psycho pedagogy for year 4, 5 and year 6, metal turning, food technology, accommodation and reception techniques were prepared and published.

Education inspectors were trained in different fields concerning the type of Education in Rwanda; these covered Inspection techniques and Early Childhood Development. 779 secondary teachers trained in English and 11 In-Service Training Centres (INSET) were established. 1818 Science and Mathematic teachers were selected and trained in Strengthening Mathematics and Science in Secondary Education (SMASSE);

621 Heads of secondary schools and 559 bursars are trained on school-management and ICT, 59 classrooms, 4 dormitories, 2 conference rooms, latrines and playing grounds were constructed,1700 computers were distributed among different secondary schools.

Education Management Information System (EMIS) team started work in January 2008. Their system guidelines for an EMIS system have been approved by Ministry. EMIS is designed to ensure efficient access, sharing and integration of data. A Monitoring and Evaluation Framework has been developed to support understanding of the M\&E process and facilitate M\&E of indicators.

Construction norms have been revised and distributed to all primary and secondary schools. The challenge is to enforce the construction norms. A Teacher Development and Management (TDM) policy was also approved and presented at the 2008 Joint review of the Education Sector. 1,968 teachers were hired on contract through the capitation grants.

A post-basic education concept paper was presented at the 2008 Joint Review of the Education sector. An ICT in education policy was developed late 2008. A TVET policy was approved and presented at the 2008 Joint review of the Education Sector.

\subsubsection{Budget execution}

Overall budget execution was $99 \%$ and capitation grants were in general disbursed on time to schools. However, there was under spend in TVET and Teacher training, while there was overspend on teacher salaries. The under spend in TVET was attributed to delays in implementation of the TVET strategy, while the strategy for expanding pre-service and in-service 
through 2 new colleges of education and a college of technology just started in 2008. Overspend was justified by the hiring of additional teachers especially to assist in the implementation of the English language policy.

\subsection{Social protection Sector}

The Social Protection Sector builds upon the Government's over arching Economic Development and Poverty Reduction Strategy (EDPRS) of poverty reduction by providing an effective social safety net and an integrated social protection program.

The sector was responsible for the achievement of 5 indicators; 3 were not due to be assessed due to no targets set and 2 were fully achieved.

Social protection was delivered to 530,086 people. 187,604 people participated in public works in 2008. Regular meetings of the Social Protection Sector Working Group have improved coordination around existing and proposed social protection interventions at a national level.

The percentage of households in the bottom two categories of extreme poverty according to UBUDEHE classification were $28.6 \%$ following a VUP survey in 2007, the progress however, could not be measured since the next survey is scheduled for mid-2009. Of the households eligible for support, the percentage granted public works was targeted at $35 \%$ which was fully realized, whilst the number of vulnerable households accessing credit and savings facilities exceeded the target of 6,390 to register 17,626. The percentage of eligible households granted direct support was also not due to be assessed as the direct support package is set to begin in 2009. The average social protection income provided to districts amounted to $33,730,605^{7}$.

The VUP program, one of the three flagship programs in the EDPRS which aims to contribute to the accelerating poverty reduction through broader coverage of social protection, started implementation in 2008. 17,262 persons participated in public works and were able to save $203,972,798$ RWF out of the $779,909,326$ RWF that they earned. Policies and procedures manuals were established as well.

A number of important policy interventions were realized including the commitment of GoR to budget allocations to the VUP program for 30 sectors which exceeded the target of 6 pilot sectors, a core management team for VUP has been established at the national level and a policy outlining criteria and transfer amounts for direct support has been established and is being implemented in VUP areas.

Furthermore, a strategy for community based participatory works (HIMO) has been developed and implementation manuals for direct support (DS) and public works (PW) programmes incorporating international good practice have been developed.

${ }^{7}$ This is the average amount received per district. 


\subsubsection{Budget execution}

The overall budget execution for social protection sector was $80 \%$.

\subsection{Youth Sector}

The role of young people in the EDPRS, as makers and targets of policy especially in the implementation phase, is of particular importance. $67 \%$ of the Rwandan population is aged less than 25 years and the past experience suggests that an idle youth is only a catalyst for political instability. For durable and sustainable economic development, youth needs not only good education, health, culture, employment but also a patriotic spirit to sustain economic development programs. Due to the importance the GoR attaches to the promotion of issues relating to youth empowerment and development a specific Ministry for Youth development has been established in 2008 .

The sector was not responsible for achievement of any specific indicator targets but rather for policy actions.

Empowering and investing in youth is an integral part of the growth of jobs flagship of the EDPRS. Effective participation of Youth in social, economic and civic development is the long term goal as envisaged in the EDPRS.

Important steps have been taken in promoting use of savings and credit facilities among the youth through youth cooperatives and initiatives. A Youth Cooperative Bank for Self employment and Development (COOJAD) is operational in 7 Districts including; Gasabo, Kicukiro, Bugesera, Kamonyi, Musanze, Rusizi and Burera. This has been supported by the Government in form of wages, purchase of office equipments and other administrative costs. Different youth associations have been facilitated through; sensitization, training and funds allocation to transform themselves into cooperatives. Also, Youth have been encouraged to combine their efforts for gainful employment through the construction of furnaces. However, not all these associations have been transformed into cooperatives due to the failure to meet all the legal requirements.

The target of supporting the transformation of fifty (50) youth associations into cooperatives was surpassed and in total, 61 associations were supported. Youth in all districts were sensitized to become members of COOJAD. They were also encouraged to support its creation. The total number of youth who are members of COOJAD increased from one thousand seven hundred (1700) to four thousand three hundred and thirty six (4336) people. Loans equivalent to two hundred fifty million Rwandan Francs (250.000.000 RWF) have been disbursed to five hundred fifty two people (552) for employment creation.

In 2008, a National Environment Youth Project was officially launched in 17 Districts. Nyamagabe and Nyaruguru were selected as the pilot districts. The main objective of this project is to employ a big number of youth while protecting the environment along river Nyabarongo.

The GoR through MINIYOUTH and COOJAD signed a Memorandum of Understanding (MOU) with the Guarantee fund of the National Bank (BNR) to facilitate the youth of Rwanda to access funds for entrepreneurship. A feasibility study of the youth employment fund has already begun. 


\subsubsection{Budget execution}

The budget execution was a meager $45 \%$. This was largely because the Ministry was only established in 2008 with a small number of employees.

Table 2.1 Summary of Social cluster performance at a glance

\begin{tabular}{|c|c|c|c|c|c|c|}
\hline $\begin{array}{c}\text { Total CPAF } \\
\text { Indicators/Targets }\end{array}$ & $\begin{array}{c}\text { Targets } \\
\text { Met or } \\
\text { Exceeded }\end{array}$ & $\begin{array}{c}\text { Targets } \\
\text { not Met }\end{array}$ & $\begin{array}{c}\text { Total } \\
\text { Policy } \\
\text { Actions }\end{array}$ & $\begin{array}{c}\text { Fully } \\
\text { Implemented }\end{array}$ & $\begin{array}{c}\text { Partially } \\
\text { Implemented }\end{array}$ & Not Met \\
\hline $\begin{array}{c}\text { 24 Indicators / 16 } \\
\text { targets (5 not set, 3 } \\
\text { not due for } \\
\text { measurement) }\end{array}$ & $12(75 \%)$ & $\begin{array}{c}3 \text { (all in } \\
\text { education } \\
\text { sector) }\end{array}$ & 44 & $33(75 \%)$ & $11(25 \%)$ & --- \\
\hline \multicolumn{6}{|c|}{ Overall Assessment: Good performance in achieving targets and policy actions } \\
but more attention should be on education sector and on target setting
\end{tabular}

Table 2.2 Summary of Social Sector EDPRS Target Scores 2008

\begin{tabular}{|c|c|c|c|c|c|}
\hline Score Level & Education & Health & $\begin{array}{c}\text { Social } \\
\text { Protection }\end{array}$ & $\begin{array}{l}\text { Water and } \\
\text { Sanitation }\end{array}$ & Total \\
\hline Green (fully met/on-track) & 1 & 7 & 2 & 2 & 12 \\
\hline $\begin{array}{l}\text { Yellow (not met but with significant } \\
\text { progress) }\end{array}$ & 0 & 1 & 0 & 0 & 1 \\
\hline $\begin{array}{l}\text { Red (not met or not assessed were CPAF } \\
\text { metadata indicates data available to do } \\
\text { the assessment) }\end{array}$ & 3 & 0 & 0 & 0 & 3 \\
\hline Not applicable & 1 & 4 & 3 & 0 & 8 \\
\hline
\end{tabular}




\section{Box 2: Social Cluster Summary challenges and recommendations}

\section{Health sector}

- $\quad$ Scaling up of the PBF financing in health institutions

- $\quad$ Greater investment is required to increase the number of youth friendly centres which were not fully achieved in 2008.

- Audit results for the mutuelles was presented that indicated that in spite of some irregularities in 6 out of 30 districts, there was no evidence of structural or systematic embezzlement. Challenges were mainly mismanagement and lack of capacity, and measures to overcome the weaknesses were proposed.

- There is a need to review the categorization of district funding and the management of funds at district level and health centre level, including between public and private and NGO service delivery and to include in the budget execution report the overall contribution of internal revenues of health facilities.

- Integration of use of bed nets in performance contracts is also of critical importance to ensure achievement of this target in future.

\section{Water and Sanitation sector}

- While there is recommendable growth in the sanitation sub sector, there is a need to separate sanitation from water with the establishment of its own sub-program and budget line as being a significant step in the challenge to meet sanitation targets.

- Environmental degradation has been a threat to the WSS causing water pollution and decrease in water surface. However, MINIRENA and MINAGRI need to keep alert and continue efforts in control measures like terracing and tree planning campaigns.

- Improving the sources of data and information for the sector indicators to be based on routine surveys to be carried out with more frequency.

- The capacity of the Districts which are responsible for progress on the ground is still very weak. The improvement in systems functionality obtained largely through the policy of delegated management to local operators will need to be sustained through consolidation and technical support

\section{Education sector}

- $\quad$ High dropout rate at $13.1 \%$ and low completion rates at primary level despite progress made.

- Ineffective data collection system causing problems to target setting in following years on key indicators

- Low number of female students in science courses in HLIs.

- Infrastructure inadequate to accommodate increasing student populations and staff; shortage of dormitories especially at higher learning institutions (HLI) and insufficient or inadequate equipment and facilities for science teaching

- $\quad$ Staffing and budgeting problems especially at HLI: comparatively low remuneration for national academic staff resulting in high turnover; difficulties maintaining expensive expatriate staff in HLI; shortage of qualified and experienced staff in key-disciplines; lack of professional development opportunities for administrative staff

\section{Social Protection Sector}

- Monitoring graduation from livelihood enhancement schemes is still a challenge because graduation is not well defined and there is little or no impact monitoring data.

- Coordination at both national and local levels is still low and will need to improve as well as greater information sharing.

- Monitoring data quality is inconsistent and incomplete and not always aligned with EDPRS targets. Particular challenges are clarity on the number of people and/or households, disaggregation and impact monitoring. This can then contribute to improved analysis of budget execution and performance. In addition to this many interventions are not captured in the sector performance reports for all actors in the sector bringing up the issue of possible double benefiting from different schemes where due attention is not given in selection of beneficiaries.

\section{Youth Sector}

- Insufficient financial resources to facilitate activities related to the scale-up and strengthening of a Youth Savings and Cooperative Bank (COOJAD) in Districts.

- High Employment Demand by Youth and low Opportunities; this call for speeding up of large projects like the recycling project and related programs which employ a big number of youth. Young people should be encouraged to embark on the road to entrepreneurship.

- Lack of baseline data to provide an evidence base to decision making on the coverage level, employment levels and existing gaps in terms of service delivery to youth. Carrying out a youth baseline survey to acquire data for evidence based planning is a priority. 


\section{GOVERNANCE CLUSTER}

The governance cluster brings together four sector working groups related to the areas of Public Financial Management (PFM), Justice, Reconciliation, Law and Order (JRLO), Decentralization, Community Participation, Empowerment, Transparency and Accountability (DCPETA), and Capacity Building and Employment Promotion (CBEP).

\subsection{Public Finance Management}

Sound macro-fiscal and budget policies are critical for making effective use of domestic fiscal revenue and donor aid. In addition, the need to improve the linkage between macro-fiscal reforms and the achievement of MDGs and goals identified in EDPRS cannot be underestimated. Improving the efficiency of spending will require further strengthening of Rwanda's fiscal institutions, including the PFM system. By promoting transparency and enhancing governance, amore effective PFM system reduces fiscal waste, and enhances value for money, and makes all stakeholders more assured that budget support is used for its intended purposes.

The sector was responsible for the achievement of 7 targets. 3 were not due to be assessed and 4 were fully achieved.

A new Public Financial Management Reform Strategy 2008-2012 was presented in September 2008 together with a detailed Action Plan for 2009-10 and approved by Cabinet in December 2008. Seven PFM indicators and related policy actions were subsequently incorporated in the EDPRS results and policy matrix.

The targets have all been met. In fact, most targets were exceeded by large margins. The implementation of the different policy actions equally shows good performance. Most of the indicators were not due to be assessed because the Public Finance and Financial Accountability (PEFA) report is only published after 3 years, the next being due in 2010/2011.

The indicator on improved multiyear perspective in fiscal planning, expenditure policy and budgeting improved could not be measured; however, different policy actions for achieving the indicator were implemented. Work on improving the MTEF and budget classification has been carried out with support of East AFRITAC. The manual for budget processes and \& procedures for central and local governments was prepared and approved.

Enhance effectiveness of payroll controls; the indicator was not assessed for 2008. Relevant policy actions achieved include the design of the Integrated Personnel and Payroll Information System (IPPIS) which is on course and the technical and functional requirements, as well as the Systems-Gap analysis have been carried out. The payroll module will be tested in February 2009. The Human Resource (HR) module has not been completed as planned and is still under development.

Index on quality and timeliness of annual financial statements; the indicator was not assessed for 2008. Nevertheless, most budget agencies have submitted fund accountability statements for 2007 and 2008 in line with a financial reporting template developed by Government. Government has used the same template for the consolidation of financial statements for the year ended 31 December 2007. According to the Auditor General's report, fourteen institutions did not submit financial statements for the year 2007. 
An update on the Capacity Needs Assessment from 2005 has not been prepared. The past recommendations are still considered relevant and implementation shall progress. The Reassessment has therefore been postponed till later in 2009. The Public Books module of SmartGov has not been finalized but is reaching completion. To ensure adequacy of the module a Quality Assurance mission led by the World Bank will visit regularly, starting April 2009.

Percentage of internal audit reports submitted; 66 central government agencies and 22 local government agencies representing $30 \%$ of all budget agencies have submitted internal audit report. Hence, the $25 \%$ target has been met. A firm to provide training on systems audit is under procurement.

Percentage of Government expenditure audited by OAG; for the financial year ending 31 st December 2007, the OAG has audited $60 \%$ of the reported government expenditure, exceeding the 50\% target set for the year. The Rwanda Expertise Scheme has been drafted but not yet approved by Cabinet in order to enhance staff qualification and retention.

Percentage of Public enterprises submitting fiscal reports; the $43 \%$ target has been met as all GBEs have submitted fiscal reports. The policy actions have been implemented as planned. A strategy to manage the Government portfolio has been developed in November 2008. The validation workshop with stakeholders is planned for May 2009. The Policy Action to "Gather annual financial statements from all Government Business Entities (GBEs)" needs to be redefined in line with the requirement for all GBEs to submit periodic reports, and also in line with the new strategy for managing government portfolio to be validated in May 2009.

Proportion of the value of procurement tendered competitively or justified; $86 \%$ of the contract value has been tendered competitively or justified. Hence, the $75 \%$ target has been met. The policy actions have been carried out satisfactorily. The institutional and legal framework has been established. Personnel have been trained in the new procurement law. An independent appeals committee has been established with some decisions being published.

\subsection{Justice, Reconciliation, Law and Order (JRLO)}

The JRLO 'sector' comprises 14 institutions, including 6 budget agencies. It recently developed a sector-wide approach and strategy for the period 2009/10 - 2012/13.

The sector was responsible for the implementation of 6 targets with 5 performance targets met, and one not met sufficiently.

$75 \%$ out of 159 cases of corruption were processed by the Prosecutor, exceeding the $60 \%$ target. A Co-ordination Committee mechanism to fight corruption was established and is chaired by the Ombudsman.

The proposed 5\% share of national public spending for the EDPRS period 2008-2012 to be allocated to the JRLOS was on target in 2008 with $5.1 \%$, or 45.6 Billion RWF. Of this total 28.1Billion RWF went into the Recurrent Budget (100\% financed by Government of Rwanda, GOR) while 17.5 Billion RWF was allocated to the Development Budget (3.4 Billion internal financing and 14.1Billion external financing). About $31 \%$ of the overall sector's financing ( $80 \%$ of the Development Budget) was provided for by external funding. Overall budget execution was $86,5 \%$ but the GoR financed part of the Development Budget as only executed by $57 \%$ due to 
delays in prison infrastructure works and the use of the 2007 budget balance to finance social insurance fees for Gacaca judges

With regards to the case backlog, both performance targets were exceeded, with the Prosecution submitting 4861 backlog cases to the courts, which judged 7965 backlog cases. Commercial courts have been established and commercial backlog cases are all cleared. A promulgation law to establish contractual prosecutors was approved by Cabinet and will be submitted to parliament.

Prison overcrowding was reduced from $140 \%$ in 2006 to $130 \%$ in 2008 , exceeding the $135 \%$ target. Rehabilitation of the existing infrastructure is continuing and income generating activities (biogas plants) are now ongoing in most prisons. Reduction of prison overcrowding is attributed to the ongoing construction and rehabilitation of a number of prisons including, Remera, Gitarama and Gikongoro. Construction of the new facility with a capacity of 1500 inmates in Butare will be completed before the end of 2009.

In order to accelerate TIG/community activities 109 work camps were opened raising over RWF 15 billions and engaging 5230 ex-prisoners and convicts who completed their sentence and/or were re-integrated into the community. There was an increase from 26,165 judgments to a total of 30,000 in 2008 indicating a speeding up of the judgment process.

From a backlog of four Human Rights reports, two were submitted in March 2009. Hence, this indicator was considered to be partially met. Furthermore, a task force on treaty bodies was put in place, led by Ministry of Foreign Affairs (MINAFFET), and 15 out of 29 Human Rights Treaties have been signed and ratified. 63\% of 997 registered human rights complaints in 2008 (incl. 325 cases carried over from 2007) were resolved, exceeding the target of $40 \%$. A complaint management system was put in place by the National Human Rights Council (NHRC) to speed up the resolution of complaints. A JRLO perception survey was not yet carried out, but terms of reference were developed and the survey will be finalized during 2009/2010.

Important achievements on human rights promotion include the training and sensitization of 149 religious groups and more than 42,000 members of human rights clubs in schools as well as 748 teachers in secondary,

Reform of criminal laws is ongoing and a draft law has been passed by parliament but has yet to be approved by the Senate, however, criminal law guidelines document has not yet been published.

An assessment of fiscal and commercial laws has been carried out as planned and capacity building for commercial and Supreme Court judges. Four (4) commercial courts have been established in Kigali, Musanze, Huye and Nyarugenge. The construction of the Institute of Law Practice Development (ILPD) is now at 60\% completion and the draft law for establishing the law reform commission is in Parliament. Furthermore, in improving the legal aid framework a study has been commissioned and is ongoing on extending legal aid. Four (4) bureau of justice have been established in Kinihira, Rwamagana, Karongi and Rusizi.

\subsubsection{Budget execution}

About $30 \%$ of the overall sector's financing (77.4\% of the Development Budget) was provided for by external funding. Only about $9 \%$ of the external financing is tentatively captured by 
Smartgov under the heading 'Development Budget external financing'. Integrating projects into Smartgov and allocating the projects to programmes should improve capturing of this data. Overall budget execution was $85.2 \%$, GOR funding performing better $(86.7 \%)$ than external funding $(81.9 \%)$.

\subsection{Decentralization, Citizen Participation, Empowerment, Transparency and Accountability (DCPETA) Sector}

This sector contributes to the EDPRS Strategic objective of enhanced gains through good governance. Decentralization also aims to strengthen fiscal and financial decentralization for Local Governments to enable them to have the resources needed to implement locally developed plans.

Phase 2 of decentralization started in 2006 and aims by 2010 to consolidate progress on national priorities, such as Vision 2020, and deepen the decentralization process by enhancing effectiveness in service delivery to communities. This will be achieved by increasing capacities at levels of administration (Villages, Cells and Sectors) close to communities, promotion of integrated local economic development and fostering community participation at Village level, in the planning and management of local affairs.

The sector was responsible for the achievement of 4 targets, 3 were not due to be assessed and 1 was fully met and exceeded.

$67 \%$ of districts achieved a minimum $80 \%$ of their service delivery targets (against a target of $62 \%)$ Progress against the second target, percentage of citizens who feel they participate actively in local decision making and that local government is listening to and addressing their priority concerns (2008 target $68 \%$ ), could not be assessed because the required data was not available. A survey took place in 2008 but did not include the required questions. This will be addressed in the 2009 survey.

Key policy achievements include; the development and endorsement of district capacity building needs assessments and plans and electoral regulatory framework was improved through the draft law on elections.

The Joint Governance Assessment (JGA) report was completed and approved by Cabinet and an integrated governance action plan draft was developed.

Parliamentary elections were organized and concluded successfully and Civil Society Organizations mobilized themselves to monitor and observe the elections, voter turn out was high throughout the country. From the elections Rwanda has a 56.25\% level of representation of female members of parliament, this being the highest in the world.

A number of legislations were approved to strengthen the legal framework of civil society, a draft law determining the organization and functioning of religious communities was developed, and a draft law determining the organization and functioning of international as well as local NonGovernmental Organizations (NGOs) were developed.

A total of 71,878 persons underwent civic education training in the Itorero Program. These included teachers, local leaders, sector executives and students studying in the Diaspora 
National Unity and reconciliation commission organized a number of reconciliation luncheons between the TIG, Genocide released perpetrators and the general public in 5 districts. To consolidate this sporting event were organized between the participants. Approximately 2,500 persons (released genocide perpetrators) completed the ingando or civic education program in 2008. A unity reconciliation week was organized and held countrywide.

Policy actions that were only partially achieved include those around participation of non-state actors in decision making bodies, rollout of the Iterero programme and finalization of the Joint Governance Assessment (JGA) implementation and monitoring strategy.

\subsubsection{Budget execution}

The overall budget execution is excellent at $101 \%$, although there are substantial variations among the execution of individual programmes. The biggest programmes are social protection and community development which account for more than $75 \%$ of the total budget and have a very high execution rate (99\% and $97 \%$ respectively). Small programmes, which account for around $5 \%$ of the total budget show more substantial under and over spend. Local administration is the most significant outlier, where the actual spend is 4 times higher than the budgeted spend. However, due to the in-year budget revision, the revised execution rate is $100 \%$. There is a significant under spent in wages and salaries and substantial over spent in goods and services.

\subsection{Capacity Building and Employment Promotion (CBEP) Sector}

The Capacity Building and Employment Promotion strategic plan has two elements. The first deals with the efficient and effective public service; and the second deal with employment promotion in the public and private sectors

There are two EDPRS indicators, one on the number of new non-farm jobs and one on the percentage of performing budget agencies, but none have 2008 targets that could be reported on, and are therefore considered not due to be assessed. A national labour force survey is planned to ensure that more employment data will be available in the future.

The percentage of performing budget agencies (achieving 80\% of annual work plans) was reported at $20 \%$. GoR has completely carried out all planned functional reviews for 17 institutions. The Districts Capacity Building Needs Assessment was planned and all 30 districts were audited. There was an increase of $20 \%$ in the number of civil servants trained: 1950 civil servants were trained, achieving $87 \%$ of what was planned. Other activities were initiated in 2008 and are still ongoing: functional reviews for 37 remaining public agencies and national commissions, development of the long term pay and retention policy, a Citizen guide, a strategy and implementation plan for the public service reform program (2009-2011), and a public service management policy.

With regards to labour administration and employment promotion, the GoR adopted a national employment policy and strategy, revised and adopted the labour code, and adopted a five years strategic plan for youth and women employment. 900 women and 300 youth were trained in entrepreneurship. 158 retrenched civil servants received training in entrepreneurship and another 178 were accepted in different higher leaning institutions through SFAR funds. 
Finally, 2008 saw the finalization of a 2008-12 Capacity Building and Employment Strategic Plan, nation-wide skills audit, human resources procedures manuals, and a revision of the Public Service Statutes.

\subsubsection{Budget execution}

The budget execution for 2008 came to $83 \%, 80 \%$ for recurrent expenditure and $90 \%$ for development expenditure. The reason for lower execution lies with the delay in the operationalization of the Public Service Commission, which as a consequence did not fully utilize its budget.

Table 3.1 Summary of Governance cluster performance at a glance

\begin{tabular}{|c|c|c|c|c|c|c|}
\hline $\begin{array}{c}\text { Total CPAF } \\
\text { Indicators/Targets }\end{array}$ & $\begin{array}{c}\text { Targets } \\
\text { Met or } \\
\text { Exceeded }\end{array}$ & $\begin{array}{c}\text { Targets not } \\
\text { Met }\end{array}$ & $\begin{array}{c}\text { Total } \\
\text { Policy } \\
\text { Actions }\end{array}$ & $\begin{array}{c}\text { Fully } \\
\text { Implemented }\end{array}$ & $\begin{array}{c}\text { Partially } \\
\text { Implemente } \\
\text { d }\end{array}$ & Not met \\
\hline $\begin{array}{c}19 / \text { total targets 11 (2 } \\
\text { not set, 6 not due for } \\
\text { measurement) }\end{array}$ & $10(91 \%)$ & $\begin{array}{c}1 \\
\text { (insufficiently } \\
\text { y achieved due } \\
\text { to no timely } \\
\text { submission of } \\
\text { human rights } \\
\text { report) }\end{array}$ & 47 & $37(79 \%)$ & 6 & 4 \\
\hline
\end{tabular}

Table 3.2 Summary of Governance Cluster EDPRS Performance Target Scores 2008

\begin{tabular}{|l|c|c|c|c|c|}
\hline Score Level & PFM & JRLO & DCPETA & CBEP & Total \\
\hline Green (fully met/on-track) & 4 & 5 & 1 & 0 & $\mathbf{1 0}$ \\
\hline Yellow (not met but with significant progress) & 0 & 1 & 0 & 0 & $\mathbf{1}$ \\
\hline $\begin{array}{l}\text { Red (not met or not assessed were CPAF } \\
\text { metadata indicates data available to do the } \\
\text { assessment }\end{array}$ & 0 & 0 & 0 & 0 & $\mathbf{0}$ \\
\hline Not applicable & 3 & 0 & 3 & 2 & $\mathbf{8}$ \\
\hline
\end{tabular}


Box 3: Governance Cluster Summary challenges and recommendations

\section{Public Finance Management (PFM) sector}

- Capacity building and monitoring and evaluation still remain areas which have to be strengthened. Nevertheless, the PFM Steering Committee had its inaugural meeting in March 2009. The process for the establishment of the PFM-Basket Fund, as a harmonized funding mechanism from 2010 onwards has started and is expected to be completed before September 2009.

\section{JRLO sector}

- Monitoring of the progress in JRLO is a challenge considering the number of institutions involved and the scope of the sector.

- $\quad$ Realignment of individual institution strategic plans to the EDPRS

- $\quad$ Need for a public expenditure review for JRLO in 2009;

\section{DCPETA sector}

- In-depth analysis of the risks and benefits of the organizational reform within MINALOC and local governments required.

- $\quad$ Quickening of recruitment for National Decentralization and Implementation Strategy (NDIS) staff to ensure better results in 2009

- 2009 action plan based on DIP priorities urgently needed for NDIS.

- Importance of establishing clear coordination and communication structure for partners and Government concerning scope of the sector.

- $\quad$ Need for more detailed budget execution analysis integrating local government component for future joint sector reviews.

- Importance of establishing and strengthening sector partnerships in data collection and commissioning of surveys.

\section{CBEP Sector}

- Lack of statistical data and baseline, it is difficult to measure performance in absence of macro level data on employment

- Funds mobilization to begin the internship program

- Coordination mechanism of public sector reform and capacity building interventions needs to be developed. 


\section{INTEGRATION OF CROSS-CUTTING ISSUES}

During the elaboration of the EDPRS, a number of cross cutting issues were identified for consideration, these being; environment, gender, social inclusion, youth and HIV/AIDS.

\subsection{Environment}

Environment was considered as a sector as well as a cross cutting issue during the EDPRS formulation Phase. Environment as a cross cutting issues primarily focuses on productivity enhancements in support of other growth sectors such as Agriculture, energy, infrastructure and private sector.

Also important common tools have been applied such as the EIA (environment impact assessment) in order to mitigate impact of different interventions on environment. The use of Environment impact assessment tools trough project was institutionalized by publishing EIA sectoral guidelines for fuel stations, slaughter-houses and tanneries, and 65 projects out of 109 submitted for certification received certificates by Rwanda Environment Management Authority.

After the publication of guidelines on mainstreaming environment in development programs at the national and local levels, planning staff in 5 key areas: agriculture, Infrastructures, commerce \&industries, local government, finance and development planning, and all 30 districts were trained in various methods of mainstreaming environment in planning processes.

Comprehensive cost based surveys for all commercial structures in Gikondo - Nyabugogo wetland system to guide expropriation of Gikondo industrial park and surrounding areas are also being conducted to avoid environmental degradation.

In the joint efforts for better management of water resources, a Master plan for watershed management was developed for 5 wetlands: Rugezi, Rweru, Mugesera, Akagera and Kamiranzovu and the rehabilitation of 22 hydrological and limnimetric stations out of 5 planned was conducted while the water information system was updated according to the data from 8 stations among those rehabilitated.

For the increase of the public awareness in the environmental management a number of activities were implemented through education sector, among others: training of teachers in southern and Northern provinces on the environmental protection, implementation of projects designed by environmental clubs created in 17 schools in 3 districts (Nyabihu,Rubavu and Rutsiro) and a needs assessments for mainstreaming environment into the national curricula was carried out in primary, secondary and tertiary education institutions.

Regarding implementation of the National Program for adaptation on climate change (NAPA) 5 Experts from the National committee on the climate were trained in the vulnerability and adaptation assessment for the second national communication on climate change.

\subsection{Gender}

It is expected that by the completion of the EDPRS in 2012, gender equity will be demonstrated in the key areas of the national economy such as growth and poverty reduction, gender equity in a 
reduced income disparity and gender equity in progress towards the MDGs. During the first year of EDPRS implementation, important achievements can be demonstrated in a number of areas;

A draft national gender policy has been elaborated with the Ministry of Gender (MIGEPROF) in the Prime Minister's office and its' key stakeholders in order to provide the GoR and its partners with a framework that guides the integration of a gender perspective into all sectors and institution.

Guidelines for gender-based budgeting have been developed by the MINECOFIN and subsequent training prepared for 2010/2011 budget preparation. All sector and district' Focal Points of gender have been trained in gender mainstreaming in the planning process. Among leaders of change, 50 church leaders were trained in mainstreaming gender into various churches programs.

A national gender profile was established as a baseline to guide the planning process in all sectors. It indicates baseline indicators of gender profile in various sectors: economic, social as well as governance during a biennial period covering 2005-2007.

By the law $N^{\circ} 51 / 2007$ of 20/09/2007, a Gender Monitoring Office in charge of monitoring the quality of gender mainstreaming in various institutions was created and 3 of its high level staff were appointed. All Gender Focal Points in all sectors are positioned in planning departments by instruction of the Prime Minister's Office in order to allow better mainstreaming of gender in planning, budgeting and policy review in various development plans.

The gender parity in net primary enrolment had already been achieved and now the rate is slightly higher for girls $(95.8 \%)$ than for boys $(94.7 \%)$. However, there are persistent gender imbalances in retention transition and completion rates at the primary and secondary levels.

More efforts need to be deployed to address issue of low attendance rates of girls in science fields at Secondary and Tertiary levels. As a consequence, the Ministry of Education has developed the Girls' Education policy in line with the national Gender Policy and a comprehensive Girls' Education Strategic Plan 2008- 2012, which will contribute to the implementation of the Girls' Education Policy and to the vision of "Quality and Equitable Education for All". The aim of the Girls' Education Strategic Plan 2008-2012 is to improve girl's enrolment, retention, completion and transition to higher levels of education.

In order to contribute to the Accessibility of Effective Quality Education: 5 Gender clubs have been created in higher learning institutions.

In the health sector, Pre-natal care coverage increased by $2 \%$ from 94 percent of women consulting a medical professional during their last pregnancy in 2007 to $96 \%$ in 2008. However, it should be stressed that the level of instruction of the mother influences in the positive manner the recourse to the care of the pregnancy. Consequently, the percentage of women who have a secondary level of instruction or more can reach $90 \%$.

The percentage of assisted births were close to 40 percent by 2005 and increased by $12.1 \%$ in 2007/2008, while mothers delivering in health facilities increased from $35 \%$ in 2007 to $45.2 \%$ in 2008. All those interventions impacted positively on the infant mortality which decreased from $8.2 \%$ in 2007 to $6.2 \%$ in 2008 . In the field of family planning, there has been a significant increase of $17 \%$ from $10 \%$ in 2007 to $27 \%$ in 2008 with a significant difference between the 
urban area (36\%) and the rural areas (26\%). Therefore, that increase impacted on the reduction of the fertility rate which decreased from 6.1 in 2005/2007 to 5.5 in 2008 with an important diminution among women in the rural areas (6.3 to 5.7) than women in the urban areas (4.9 to 4.7).

Measures to improve targeting of health services to poor women especially consisted of the supply of insecticide Treated Long Lasting mosquito nets. In the same way the policy of providing free deliveries to women who have attended antenatal care clinics was implemented and impacted in expanding access to assisted deliveries.

In the area of pandemic diseases, concerted efforts to target HIV/AIDS and TB interventions to poor women who are disproportionately affected were combined. The significant program implemented is the Prevention of Mother to Child Transmission (PMTCT) which was extended to 336 sites in Rwanda by the end of 2008 .

The promotion of efficient utilization of fuel wood and creating alternative energy sources to address the over-dependency on fuel wood which often impacts on girl children who have to trek miles to collect firewood was enhanced by training 80000 people in making improved cooking stoves and 200 people in economic carbonization which resulted on making 80000 new cooking stoves in 7 districts of the country (Muhanga, Kamonyi, Rulindo, Gekenke, Nyaruguru and Nyamagabe).

In private sector development integration has not been significant, only a chamber for women in Private Sector Federation has been created and this will be included in future consultative meetings.

In judicial reforms, Rwanda continues to make considerable efforts to give to all its nationals the same chances to participate in the management of the public institutions. Rwanda is signatory to nearly all international conventions specific to women's rights, having already ratified 14 of these instruments.

Rwanda currently holds the world record as regards participation of the women in the Parliament as a result of the 2008 Parliamentary elections. The female representativeness currently reaches $56 \%$ in the Chamber of Deputies and $34 \%$ in the Senate. The Chamber of Deputies is currently chaired by a woman.

A number of discriminatory aspects of certain legislative texts in gender are under revision such as; the penal code, the civil code, the Decree of August 2, 1913 relating to the tradesmen and the proof of commercial engagements, the Decree of July 27, 1934 relating to bankruptcy and the preventive legal settlement with the bankruptcy, and the Decree of April 15, 1958 relating to mutual associations.

\section{$5.3 \mathrm{HIV} / \mathrm{AIDS}$}

The fight against HIV and AIDS is addressed not only as a health issue but as a crosscutting development issue, requiring all EDPRS sectors to include it deliberately and actively into their strategic planning. That is the reason of why the first concern has been to review and elaboration of a specific multi-sector strategic plan to fight against HIV and AIDS aligned to the EDPRS, as well as the integration of the fight against HIV and AIDS in the sectors strategic plans as reflected in the EDPRS logical framework of each sector. 
In the beginning of 2008 the sectors capacity needs assessments was conducted to all sectors to determine the needed capacity building for a better implementation of HIV related issues, as it was a new concept for many sectors.

At the district level, all the 30 districts have been supported to incorporate HIV AIDS as appropriate into the district integrated planning tools such as MTEF and AWP. The CNLS has continuously advocated to districts local authorities to strengthen their ownership in the fighting against HIV via several supervisory field visits conducted across the country.

In the health sector: at the health facility level $81 \%$ of health centers are providing Volunteer Counseling and Testing (VCT) services; $73 \%$ provide Prevention of Mother To Child Transmission (PMTCT) services and 47\% offer Anti-retroviral. The total number of condoms distributed increased, representing a 63\% increase of condoms distributed from 2007.

\section{Challenges and recommendations}

- The main challenge lies in the ownership by different sectors of their role in fighting against HIV as an EDPRS cross cutting issue, as they are key players in HIV prevention and impact mitigation. There is a reluctance of sectors to use their own budget to fund HIV activities for which they have committed in the EDPRS. There is therefore need of advocacy by highest level in each sector to strengthen their ownership in the fight against HIV.

\subsection{Social inclusion}

Social inclusion targets the development and reintegration of persons or households that are disadvantaged or marginalized in the past due to circumstances. These may be vulnerable persons, genocide survivors, refugees, returnees, disabled people and the OVCs.

The $3^{\text {rd }}$ and $4^{\text {th }}$ report on the implementation of the convention related to child rights was elaborated. In order to better deliver services to orphans and vulnerable children, a guideline on the minimum package will be published in 2009 to guide multiple interventions.

Solidarity camp for street children was carried out and many of them were oriented to primary schools and 120 retained in their families. Employees of children centers were trained on small bankable projects and protection of children from drugs. At local level, support has been provided to create a transit center for street children in Rubavu District. 


\section{AID HARMONIZATION AND COORDINATION}

Following the launching of the Development Assistance Database (DAD) in March 2006, the Ministry of Finance and Economic Planning (MINECOFIN) continues to further develop the tools that it has at its disposal to better plan and manage the country's external resources. Several key activities were undertaken during 2008 in an effort to further develop the DAD and also to enhance the skills and knowledge of those who manage it.

In mid-September, work begun on the development of a module that would enable the Government to better monitor some of the key indicators on the quality of aid - Donor Profile Module. This was agreed on with development partners, with a view to facilitating real-time monitoring and transparent publication in the context of the Donor Performance Assessment Framework (DPAF). This module will also assist in better monitoring donor portfolios as they evolve over time.

\subsection{DPCG-BSHG and DPM}

The framework for development partners' coordination and harmonization includes the Budget Support Harmonization Group (BSHG), the Development Partners Coordination Group (DPCG) and the Development Partners Meeting (DPM).The Development Partners Coordination Group (DPCG) Meetings were held in July and October 2008 respectively.

A Joint Budget support review was held in September 2008. The main focus of the meeting was to review the Budget Framework Paper, budget execution performance and present the Public Investment Program to budget support donors. The September review gave the opportunity to sector Ministries to report on the progress against a number of issues such as the NGO financing in health, staffing challenges in Mineduc, update on the LWH and the Crop Intensification Program for the Ministry of agriculture. Budget support donors and the GoR signed a new Partnership Framework in September.

The Partnership Framework outlines commitments in three overarching areas: macroeconomic stability and the establishment of an economic environment conducive to growth and employment generation, comprehensive and effective public financial management, and strong policy formulation informed by M\&E.

The eighth Annual Government of Rwanda and the Development Partners Meeting (DPM) was held from 27-28 November 2008. Representatives from different governments and organizations participated in the Meeting which the theme of this year's conference was: "Beyond Aid: Innovative Mechanisms for Financing the EDPRS'. The conference agenda included Good governance; a review of macroeconomic performance and challenges; progress and challenges in the implementation of the EDPRS, emerging sources of development finance, review progress against the Monterrey Consensus and Paris Declaration and, at the invitation the Government, a donor-led presentation and discussion focused on mutual accountability. 


\subsection{Support to further development of SWAPs}

The GoR has embraced the idea of developing further sector wide approaches (SWAPs) in different sectors of the economy. SWAps brings together different stakeholders in development that is to say; government, donors, private sector and civil society. For SWAPs to be effective, it is important for the targeted sector to share one common plan, one budget, one Monitoring and Evaluation system and reduce transaction costs through further use of government's public financial management system. This year saw the Agriculture and Energy sectors sign a SWAp memorandum of understanding with the stakeholders. The justice sector is working on its strategic plan, once completed; a memorandum of understanding will also be signed with all the stakeholders.

\subsection{Reducing fragmentation and duplication of donors}

MINECOFIN conducted a survey on the comparative advantage mid 2008 with its donors both bilateral and multilateral excluding UN agencies, IMF and Global fund given the nature of their support being specifically allocated to some specific sectors -for instance global fund allocates its funds to the health sector only. Findings were presented to the DPCG meeting of July 2008. Majority $(83 \%)$ of donors filled the questionnaire where they self assessed themselves and identified areas where they would like to be actively involved.

The remaining work to be done is to put a blue print to this after a thorough assessment from government side. The assessment will be based on whether the sectors are equitably represented this will prevent some sectors from lagging behind.

The manual intends to give guidelines on aid delivery as stipulated in the aid policy which was endorsed by cabinet in 2006. The manual's first draft has been finalized. MINECOFIN will hold a workshop early next year bringing together high level government officials and donors to have an in-depth discussion on the manual. This will be followed by a formal adoption of the manual. 


\section{CONCLUSION}

In general implementation of the EDPRS in positive: $81 \%$ of the targets set were met or exceeded, with the strongest performance in the Governance cluster which had an overall implementation of $91 \%$ of targets, whilst the economic and social cluster achieved $78 \%$ and $75 \%$ respectively. With regard to the performance in implementing policy actions, overall performance was good with $80 \%$ achieved, $16 \%$ insufficiently achieved and $4 \%$ not met.

The key challenges to be addressed include;

The effects of the global financial crisis on the value of key exports especially in the mining and agricultural sector needs to be closely monitored and strategies developed to counter any negative impact. The rate of inflation which rose to double digits is expected to subside as global international oil and commodity prices are projected to decrease in 2009.

Also monitoring and evaluation systems in some sectors needs to be further improved. A number of indicators were not reported where they should have been reported in the agriculture and transport sectors, whereas baselines and target setting have been an issue for the education and environment sectors.

In the environment sector all the indicators relating to land registration process were not met and measures should be taken to accelerate this in 2009 following the completion of aerial photography.

In the education sector; a number of key issues need to be addressed to improve performance such as the repetition and drop out rates, so as to increase overall school completion performance and the need for incentives to female students to take up science courses in higher learning institutions. The transition from basic education to upper secondary school did not meet the target which has been attributed to poor baseline information. The completion of the EMIS should be fast tracked to enable the acquisition of quality information.

In addition to this, there is a need to strengthen and improve intra and cross sectoral communication and coordination and build more synergies.

As regards the implementation of policy actions there were also a high number of partially achieved policy actions ( 28 out of 144), a particular attention should be paid to the completion of policy actions in the agriculture (1), capacity building (1), DCPETA (3), environment (2), PFM (4), health (8), water and sanitation (3), JRLO (2), Private sector (2) and culture (2). The partial implementation of these policy actions risks to adversely impact on the attainment of targets set in 2009 and the following years. 


\section{ANNEXES}

\section{PROVINCE AND KIGALI CITY SUMMARY REPORTS}

\section{KIGALI CITY}

\section{Key achievements}

Housing and land use management; Housing in Kigali is mainly composed of informal settlements; slums and modern houses in unplanned settlements. This led to the development of a plan to guide the City into a self sustainable urban development "The Master Plan". In 2008, Kigali City master plan was approved by Cabinet. Its Implementation commenced with the development of detailed plans for Lower Muhima, Nyarugenge, Kimihurura gateway, Kimicanga and Kinyinya and Akumunigo covering a total area of 288ha

Approximate $83 \%$ of the urban population in Kigali is located with in informal settlements and indecent housing (slums) that need to be re developed. The issue has been to provide alternative good quality housing with basic amenities to the slum inhabitants. In collaboration with National Socio security fund of Rwanda, Kigali City council built 250 low cost houses in Batsinda with subsidized infrastructure at a cost of 1.9 billion to relocate those displaced from slum areas being re-developed.

District land commissions were established to ensure speedy and efficient service delivery in terms of providing land and building permits to those who need them. A technical commission to approve the architectural designs for big building projects in the City was established. This has considerably reduced the number of illegally constructed houses in the city and has improved the safety of workers at the construction sites.

Infrastructure development; The roads in and around the City have suffered serious deterioration and are in need of repair. Kigali city council with the help of its partners develops and maintains its Road Transport Infrastructure. In 2008, a number of important roads were built (Kinamba - Memorial centre-Kagugu, Giporoso - Kabeza, Kimironko - Nyandungu) totalling to $15.9 \mathrm{~km}$ of tarmac road, $6 \mathrm{~km}$ stone paved road (Gikondo - Rebero, Kagarama, Sonatube , Giporoso and Mushumbamwiza-Kanombe). In addition, $12 \mathrm{~km}$ of ravins were constructed (Migina - Bibare, Akumunigo, Kimihurura, Giporoso - Kabeza, Kacyiru and Rukiri). In addition, 25 passenger shelters were constructed against 22 that were planned across town.

Maintenance and repair of gravel roads and sidewalks is a duty of districts with funding from the Road maintenance fund by the Ministry of Infrastructure and TIG. In 2008, $312 \mathrm{~km}$ of earth road were constructed by convicts serving their TIG sentence in all Districts of Kigali.

Electricity and Water infrastructure in the City are developed by the National agency Electrogaz and the City supplements by exploring and promoting alternative energy and clean water sources.

Development of Agriculture and Livestock; Agriculture production in Kigali City has been boosted by the adoption and implementation of the Integrated Development Program (IDP). Under this program, a number of initiatives are envisaged including, rural settlements commonly known as "Imidugudu", agriculture development through terraces, land consolidation, provision of fertilizers, increasing production and processing of agro-products and environmental 
protection. Agriculture and Livestock activities are predominantly located in peri-urban areas of the City.

Kigali City promotes the Coffee growing, Horticulture and Sericulture as its priority agricultural intervention areas. Kigali boosts of 10,206 Tones of Coffee production for the year 2008 with 7,402 Tones from Gasabo district that is largely peri-urban, 1,947 and 857 Tones from Kicukiro and Nyarugenge districts respectively.

In Horticulture, Kigali city had 23 green houses with an average production capacity of 14 Tones of Tomatoes each per annum and there is a plan to increase them to 48 by June 2010. Pineapples were grown at a surface area of 300ha, with 150ha in Gasabo District, 100 in Kicukiro and 4ha in Nyarugenge districts.

Mulberry was grown at a total surface area of 45 ha in 2008 but sericulture having been identified as one of the viable sector in which agricultural cooperatives in Kigali City should invest, the City council plans to have 600 ha of land planted with mulberry by 2012 .

By end 2008, Kigali City had a population of 41, 090 Cow, 68, 785 Goats, 113, 812 hens, 21, 787 Rabbits and 5, 040 Pigs. The rising numbers of the live stock population goes along with improved living condition of the people of Kigali.

Under one cow one family program, a total of 492 cows were distributed to families in 2008, Nyarugenge distributed 134, Gasabo 220 and Kicukiro 138 cows.

In agro - processing, Kigali City has 73 Agro processing plants that help add value to the agricultural production from Kigali and from the rest of the country. These however remain few given the supplies from the rest of the country. With the City's projected production increases the situation is likely to get worse.

By end 2008, total area of $38,364.58$ ha were free of soil erosion, equivalent to $65.18 \%$ of the total area that needs to be protected from soil erosion. Construction of radical and progressive terraces and tree planting are some of the soil erosion mechanisms use in Kigali City. 299ha of radical terraces were constructed in 2008 alone.

Labour and entrepreneurship development in Kigali city has been promoted especially through creation of cooperatives. A total of 532 cooperatives were formed in all Districts in the year 2008 .

Vision 2020 Umurenge in its public work component provided job opportunities to 240 people in Gasabo, 381 Nyarugenge and 500 in Kicukiro in 2008.

Good governance, Justice and Security; In 2008, Out of the 18,560 Gacaca cases, 20,613 judgements were passed equivalent to $99 \%$.Elections for members of parliament, the Chamber of Deputies were organized and 540,585 of 544,802 eligible voters cast their vote, ranking Kigali the first in the country with the highest voter turnout rate of $99.2 \%$.

Security in Kigali City was generally good in 2008 but as a result of security reinforcement mechanisms, criminals arrested in Kigali showed an increasing trend compared to 2007 figure. The number of thieves arrested increased from 391 in 2007 to 569 in 2008, rape cases dropped 
from 388 in 2007 to 348 in 2008, drug users arrested increased from 243 in 2007 to 254 and Domestic violence cases increased from 461 to 490 in 2008.

TIG program in Kigali City constructed $312 \mathrm{~km}$ of earth roads, prepared 414,261 tones of stones for road construction, constructed 299ha of radical terraces and constructed 67 houses for the vulnerable in 2008. The total investment by the Districts in TIG program was equivalent to $1,126,802,227 \mathrm{Rfw}$ with TIG output estimated at 3,064,576,085 hence demonstrating the viability of using TIG program in building local infrastructure. A total of 6,870 TIG convicts worked under this program in 2008.

Provision of social services; Kigali city social amenities such as Schools, Hospitals, Shelter and recreational Centers are being stretched by the ever increasing city population. This calls for a proportionate increase of these amenities. In 2008, 118 primary school classrooms were constructed in Kigali City bringing down pupil class room ration to 56 from 59 in 2007. In secondary schools, 17 classrooms were constructed reducing the student-classroom ratio by one from 46 in 2007 to 45 in 2008. 4,134 a primary school pupils and teachers accessed computers under One laptop per child program in 2008.

In terms of health, 854,485 people out of $1,024,423$ residents of Kigali have access to health insurance of one form or the other and 96,360 houses out of 103,532 were sprayed with Mosquito killing spray.

Kigali City council understands social services as going beyond schools and hospitals and addressing needs of marginal groups such as orphans and street children. During the course of 2008,359 houses for the vulnerable were constructed superseding the set target of 300.386 child headed families were connected to guardians and 280 street children were taken off the streets and were integrated into children centers.

Under UBUDEHE program that aims to improve the living conditions of the very poor fabrics of the Rwandan society benefited all Villages (Imidugudu) in Kigali City.

\section{Key challenges}

- Urban housing and land use planning has remained the biggest challenge for Kigali City. Being one of the fastest growing Cities in the world, Kigali remains at the centre of rapid urbanization challenges. Expropriation of the existing slums and relocation of the inhabitants is costly hence making Master plan implementation far from being realized.

- Existing infrastructure network is inadequate and needs to be strengthened in order to accommodate projected future growth.

- Weak Monitoring and evaluation system to take stock of progress made in all development aspects of the City.

- Unregulated and chaotic intra and inter-City public transport.

- Increasing high cost of living in the City

- Increasing Unemployment levels especially in young people leading to high levels of drug abuse and prostitution 
- Capacity building gap

\section{Recommendations}

- There is need for greater coordination and harmonization of poverty reduction interventions by all stakeholders across the City.

- Need to speed up the baseline survey report that was conducted by the National Institute of Statistic so as determine the overall statistical stand of the City and subsequently establish a strong monitoring and evaluation system.

- Public transport has to be further regulated to provide the most reliable service possible especially for intra - City travels.

- Appropriate waste management systems have to be put in place to ensure both public and environmental health.

- There is need to bring down the cost of living in the City that has parachuted in last few years and is becoming increasingly unbearable for the low and irregular income earners.

- Improving the City's financial resource mobilization capacity

- Capacity building

\section{SOUTHERN PROVINCE}

\section{Key Achievements}

- The Crop Intensification Program (CIP) has been implemented and considerably reduced the hunger and poverty in Southern Province: Cassava and Coffee (in all Districts), maize(in all Districts, especially in Nyanza, Gisagara, Kamonyi and Ruhango),maracouja (in Nyamagabe), pineaple (in Gisagara);

- $70 \%$ of the total area of the Southern Province were protected against Erosion by adequate erosion control infrastructures;

- At the end of 2008, 8 forest master plans (each by District) were being finalised in the Southern Province;

- 7, 979 families gained modern cows through Girinka progam and other 2,097 have benefited from loans in Popular Bank of Rwanda under Girinka grants agreements between the Government of Rwanda and Popular Bank of Rwanda s.a;

- Joint Action Development Forums (JADF) have been operational at Provincial, District and Sector levels;

- Performance contracts have been evaluated in all Districts as where as development partners;

- The decrease of $20 \%$ in number of crimes was registered in the Southern Province (comparing 2007 and 2008 data on crimes in Southern Province);

- Gacaca cases have been judged at the rate $99,7 \%$ for third category, $99,9 \%$ for the second category and at the rate of $38 \%$ for the first category; 
- Among 20 coffee lots that gained the awards in the 2008 Coffee Cup of Excellence Competition, 12 lots are from the Southern Province and population are really interested in increasing coffee trees, maintenance and productivity;

- Drop out rate in primary schools has been decreased to $1 \%$;

- 5,100 poor and vulnerable families were targeted to benefit from shelter program in favour of vulnerable groups: 1028 houses have been finished, 3,273 houses were about to be finished and 799 were under construction;

- $90 \%$ of the population were covered under the health insurance scheme;

- $70 \%$ of births were assisted in the accredited health facilities;

- 5 Districts (Gisagara, Huye, Nyaruguru, Nyanza, Kamonyi) supported the youth initiatives in Youth Credit and Saving Cooperative(COOJAD)creation and operation;

- Every village chose a hill of excellence and special inputs were targeting the acceleration of the integrated development though this program;

- Every District has identified an industrial park and industries were increasing in number and in capacity: 4 additional coffee washing stations, 1 factory in cerials processing (Huye), 1 tannery (Huye), 1 in maracouja processing (Nyamagabe), 1 small factory in cassava processing (Huye) and preparations were done to begin the construction of a big cassava based factory (Ruhango).

\section{Challenges}

- Bad rain flow that have had negative impact on the agriculture production and on shelter program for vulnerable people;

- Slow mindset change process that had impact on " medical insurance subscriptions";

- Insufficient financial resources and small amount of development partners in some Disticts (Ruhango, Gisagara, Nyanza, Huye);

- Some Popular Bank of Rwanda sub-branches have gone slowly in integrating Girinka Program

- Insufficient ICT equipment in local government institutions' offices (Cells and Sectors)and lack of source of energy (electricity);

- Some Agronomists for Districts and Sectors without means of transports (motorcycles);

- Supports to local government institutions (Districts) that were sometimes late.

\section{Activities, measures and programs to overcome the challenges}

- Sensitization on different issues including family planning, settlement in IMIDUGUDU, security maintenance, HIV/AIDS, Gender Based Violence, corruption fighting;

- Solar energy projects in favour of cells' offices;

- Lobby for means of transports in favour of agronomists who did not received the motorcycles;

- Enhancement of community based initiatives;

- ICT equipment to be given to local government institutions' staff (cells and sector) as where as installed in their offices; 


\section{Priorities and plans for 2009}

- Special attention to the promotion of habitat in settlements;

- Implementation of nine years basic education program;

- Increase livestock and agriculture productivity;

- Strong follow up of performance contracts for Villages (IMIDUGUDU) and families;

- Special attention to VUP and Hill of excellence Programs (gahunda y'Agasozi Ndatwa k'Umudugudu);

- ICT equipment in local government institutions offices and staff;

- Electricity installation in local government institutions offices (from ELECTROGAZ or generated by solar energy)and promotion of solar energy among the population;

- Industry promotion especially industries based on agro-business;

- Tourism promotion: studies and preparation of tourism sites;

- Cooperatives promotion: increase in number and in production.

\section{NORTHERN PROVINCE}

\section{Key Achievements}

- Excelled in controlling soil erosion mainly using radical terraces through out the Province: the land protection against soil erosion is $81.64 \%$;

- The Crop Intensification Program (CIP) has been implemented and considerably reduced the hunger and poverty in Northern Province: Irish potatoes (Musanze, Burera and Gicumbi District); Coffee (in Gakenke, Gicumbi and Rulindo Districts), maize (in Burera, Gakenke and Musanze Districts), Tea (Gicumbi and Rulindo Districts), Wheat (Musanze, Gicumbi and Burera), pineapple (Gakenke, Rulindo), sun-sip (Gakenke and Rulindo Districts).

- About $60 \%$ of the all families gained modern cows through Girinka program;

- Joint Action Development Forums (JADF) have been operational at Provincial, District and Sector levels;

- Performance contracts have been evaluated in all Districts as where as development partners;

- Gacaca cases have been judged at the rate $98.36 \%$ for all categories

- Primary school net enrolment $84 \%$

- Poor and vulnerables families were targeted to benefit from shelter program in favour of vulnerable groups: 940 houses have been finished, 2241 houses were about to be finished and 3248 were under construction;

- $91.36 \%$ of the population were covered under the health insurance scheme;

- $78.3 \%$ of births were assisted by skilled health personnel;

- Every village chose a hill of excellence(Agasozi Ndatwa) and special inputs were targeting the acceleration of the integrated development though this program;

- $96 \%$ of Children are immunized against measles;

- First initiators of the kitchen garden (Akarima k'Igikoni) in the Country;

- Excellent in mobilizing the population to fight against genoside ideology; 


\section{Key Challenges}

- Budget constraints that limits coordination activities;

- Supports to local government institutions (Districts) that were sometimes late;

- Insufficient financial resources and small amount of development partners in some Disticts (like Burera);

- Some Popular Bank of Rwanda sub-branches have gone slowly in integrating Girinka Program

- Insufficient ICT equipment in local government institutions' offices (Cells and Sectors)and lack of source of energy (electricity);

- Mountainous region decelerating Imidugudu settlement program and land use consolidation.

\section{Measures and programs to overcome the challenges}

- Sensitization on different issues including family planning, settlement in IMIDUGUDU, security maintenance, HIV/AIDS, Gender Based Violence, corruption fighting...;

- Solar energy projects in favour of cells' offices;

- Enhancement of community based initiatives;

- ICT equipment to be given to local government institutions' staff (cells and sectors) as where as installed in their offices;

\section{Priorities for 2009-2010}

- Increasing the number of microfinance institutions to the extent of one microfinance institution per Sector to accelerate local investments;

- Promoting non agricultural jobs to eradicate extreme poverty;

- Implementation of nine years basic education program;

- Raising accessibility to potable water by the population through private sector initiative;

- Increase livestock and agriculture productivity;

- Accelerating IMIDUGUDU settlement program with target of $80 \%$ by 2010 ;

- Special attention to VUP and Hill of excellence Programs (gahunda y'Agasozi Ndatwa k’Umudugudu);

- Transformation of volcanic stones into cement, through private sector initiatives in order to increase production of cement, Employment and family income;

- Entice local and foreign investors to invest in bricks making industries (Amatanura) in order to solve the problem of building materials in the Province;

- Expand wheat plantation through private investors in order to satisfy wheat factories existing in the Province;

- Industry promotion especially industries based on agro-business;

- Cooperatives promotion: increase in number and in production.

\section{EASTERN PROVINCE}

\section{Key Achievements:}

- Land consolidation has been promoted in most of the Districts and this has promoted adequate settlements and mechanization in the Province. In addition land has been shared in 
that, $6,062 \mathrm{Ha}$ of land has been distributed (2,592 given to crop farmers and 3,470Ha were given to pastoralists.). Though $424 \mathrm{HH}$ and $470 \mathrm{HH}$ in Nyagatare and Gastibo have not yet been distributed.

- 67/95 sectors have administrative offices constructed with 57 sectors having electricity. Also 64 cells have constructed administrative offices with the help of the community and 8 cells have electricity; In total 232/503 have administrative offices constructed, although169/503 cells still lack offices.

- ICT has been promoted in the province with 95 sectors being equipped with computers and 52 sectors have internet connection.

- The nursery schools in the province are 1226; primary schools are 456 and secondary schools 137. The high learning institutions are 4(Nyagatare, Ngoma and Rwamagana).

- Health centers are 22; Hospitals are 9 and Dispensaries 87.

- The primary and secondary teachers are 8,710; the health sector has 1301 employed with the nurses being 1241 and doctors 60 .

- $95.07 \%$ grassroot leaders $(13,174 / 13,857)$ were trained, $96.52(7,145 / 7,402)$ mediators/Abunzi were trained.

- In areas of promoting the media, 64 radio talk shows were organised on Radio Izuba.

- Tenders awarded at the Province were 28 and 345 tenders were awarded at the District level.

- $98.70 \%$ of the population illegible to voting participated in parliamentary elections.

- New National Identity Cards were distributed and 63.9\% (639886) people paid for them although, 1168151 of the population were supposed to receive the new IDs.

- $67.6 \%$ (6614/9780) Tigistes participated in TIG and the value of their works was $2,537,060,800 \mathrm{Frw}$ although, $740,678,138 \mathrm{Frw}$ was spent on them.

- $1396 \mathrm{HH}$ of returnees from Tanzania were settled with $67.2 \%(865 / 1287)$ Houses constructed for them.

- $49.6 \%(1,299 / 2,621)$ households for vulnerable groups were constructed houses and 757 Houses are under the finishing level with 82 of the other houses also being on the foundation level.

- 181 Houses have been constructed for marginalized groups, 73 Houses are also under finishing and the remaining ones are 241 houses although 471 marginalized groups were supposed to be constructed houses.

- $78.64 \%(3,843,051 / 4,886,928)$ of the population participated in Umuganda with the value of Umuganda being 1,385,612,923Frw.

- $99.96 \%(88,228 / 88,256)$ Gacaca cases in the third category were resolved although in general 28 cases in Kayonza and 37 cases in Ngoma still remain standing.

- Production in Agriculture sector was valued at 97,650,173,932Frw.

- The $160,561 \mathrm{HH}$ had cattle although $60.44 \%(245,274)$ had no cattle. The one cow one family program gave out 222,287 cows to the community. Also 14,319 cows were inseminated, there 20,212 exotic cattle, 64,961 cross breeds and 294,276 local breeds.

- The other livestocks are 411,782 goats, 50,397 sheep, 34,155 sheep, 464,327Hens, 22,355 Rabbits and the total production was worth $22,012,454,650$ Frw.

- Grain storage was promoted with 215 cocoons in place and 2679.6T was stored.

- With the promotion of value addition in the province, 37 agro processing units are in place and 6 plants for diary production. 
- Cooperatives were promoted with 1462 cooperatives in place and 379 were legally accepted.

- Off farm activities have been promoted with 5401 people employed in agro processing units and 47946 employed under arts and craft and other generating activities.

- SACCOS/COOPEC has been promoted in that, 42 branches of banks are in different parts of the Province and 40 branches for COOPEC.

- Settlements have been promoted through most of the community being in villages/Imidugudu except for $26.75 \%$ of the community that still remains.

- $49.2 \%$ (64/130) of the commercial centers have been rehabilitated and others are also in the process of being rehabilitated/reconstructed.

- Irrigation in the Province has been promoted through 1907Ha being under irrigation.

- Terraces were constructed with $1611 \mathrm{Ha}$ for radical and $19520 \mathrm{Ha}$ progressive although 154433 Ha remain to be constructed.

- $17717 \mathrm{Ha}$ have been planted on forests and also most of the Districts except for Nyagatare have forestry master plans.

- There are 35 marshlands/swamps and $4380 \mathrm{Ha}$ of marshlands have been protected and maintained.

- The mining sector has been promoted with 131.5Tones being mined and generating in $34,896,000 \mathrm{Frw}$ revenues.

- $10070 \mathrm{HH}$ have electricity from Electrogaz, $152 \mathrm{HH}$ use solar energy and $135 \mathrm{HH}$ use biogas.

- Also $300 \mathrm{Km}$ of drainage channels were maintained.

- The revenues generated by Districts were $73.5 \%(169,643,441 / 2,308,629,905 \mathrm{Frw})$.

- The tourism sector has been promoted with 30 sites being put in place.

- 500,004 pupils were enrolled in primary schools, 58,774 students in secondary schools. In primary schools 15,723 pupils completed school and 8,836 completed the school level.

- The health sector has been promoted with 9 Hospitals being in place, 93 dispensaries and 12 Health centers were being constructed. The deliveries in hospitals were at $75.23 \%($ $56,050 / 74,499)$ women and the maternal mortality rate was at $8.72 \%$ ( 65 died), the infant mortality rate still remains also a challenge in that 700/1000 children died, $97.9 \%$ $(78,436 / 80,079)$ children were immunized.

- $85.37 \%(1,792,884)$ of the community was covered under health insurance.

- The HIV/AIDS prevalence is at $3.78 \%$ in that out of 311,881 people that went for HIV/AIDS testing only 11,803 were HIV positive.

- Family planning is at $20 \%$ (81408).

- There has been a fight against malaria with $51.3 \%$ of the House holds sleeping under mosquito nets.

- Security has been promoted in the province with $97.5 \%(15,884 / 16,287)$ of the community being trained in community policing. 67.1\% (2523/3760) Local Defense forces were also trained. Crimes were also reduced at $94 \%$.

- $98.8 \%(12,671 / 12,817)$ of individuals were enrolled in civic education/Itorero as compared to the number that was to be enrolled.

- The youth and women have been promoted with the establishment of 38 cooperatives for the youth and 115 cooperatives for women.

- The private sector has also been promoted with 11,473 entrepreneurs involved in various businesses. 


\section{Key Challenges:}

- Lack of Monitoring and Evaluation Framework/ Systems in all the Districts and this makes data collected to be un- realistic and inconsistent in most Districts.

- Insufficient funds due to some of the development partners not fulfilling their commitments

- Corruption is still a challenge mostly at the grass root level.

- Unpredictable seasons both for wet and dry seasons.

- Price fluctuations

- Limited capacity

- Food storage

- Increased rural to rural and urban to rural migrations

- Increasing population that does not rhyme with the resources.

- Increased fraud of fertilizers

- Trafficking of crude waragi still remains a challenge and this has resulted to domestic violence and other crimes.

- Savings culture still remains a challenge.

- Distribution of land titles and registration of land

- Gender disaggregated data

\section{Recommendations:}

- Need to establish Monitoring and Evaluation Frameworks in all Districts to ensure consistence in figures given and a culture of $M \& E$ in all units and where possible it should be budgeted for.

- There is need to dialogue with development partners such that they fulfill their commitments and also a need to establish a sovereignty fund that can reduce foreign dependency.

- Public finance management needs to be emphasized and promotion of transparency and accountability through setting up community committees that need to monitor such corruption cases.

- Rainy seasons need to be fully utilized

- There is need to train all the Eastern Province staff in all areas including Monitoring and Evaluation

- There is need to be speculative and being aware of a likelihood in case of price changes

- A law should be introduced that disables immigrates from establishing grass thatched houses in places that they have migrated to as well as carrying out activities that hinder the development of that area.

- Population should be controlled through sensitization and use of other mechanisms like use of family planning methods.

- There is need to set up a law that punishes fertilizer theft and fraud as well as trafficking of crude waragi.

- SACCOS need to be introduced in all sectors and need to be strengthened.

- There is need to implement the land registration and distribution of land titles

- Gender trainings need to be enhanced country wide as well as for other cross-cutting issues. 
- Storage of food in cocoons and by use of other methods is necessary since it has been observed that it has again backslide in different Districts which can bring food insecurity during the dry spell hence causing hunger.

\section{WESTERN PROVINCE}

\section{Key achievements}

All Districts have achieved the targets at an average of above $85 \%$

VUP public works Activities started and were operational at least in 5 pilot sectors of Western Province with an exception of Nyakarenzo in Rusizi \& Muhororo in Ngororero Districts and all the beneficiaries have opened accounts and been paid on their respective Accounts.

With help of some CAPEC's operating in particular sectors, savings for workers involved in public works rose to more than 15 Million and Rurembo sector in Nyabihu District opened saving cooperative

There has been construction of Roads linking sectors at a rate of $45 \mathrm{Km}$ and $687.2 \mathrm{Km}$ have been constructed through out 7 Districts

A total of 327 houses are being constructed for people who were displaced by catastrophes in Rubavu and Nyabihu Districts. In addition to this 5,917 Houses for vulnerable people were being constructed, so far 255 houses have been completed and 5,662 were due to be finalized.

All Districts have started to grow the selected crops in the respective District.

- 31,450,692 ha of coffee are well grown\& extra 266 Ha have been added on this year

- 7,463,540 HA of tea are well grown \& extra 655 Ha have been grown this year.

- $2,448 \mathrm{Ha}$ of rice are grown in Nyamasheke and Rusizi Districts

- 3581 cows were distributed to poor households in 2008

- 7 forestry Master plans were developed through out 7 Districts of Western Province

\section{Key challenges}

- Western Province Investment Corporation began in 2008 but there was no subscription of shares by shareholders.

- Late Disbursement of earmarked transfers.

- There is no clear and concrete M\&E for decentralized levels

- Late disbursement of funds requested as $2^{\text {nd }}$ transfer for some Districts. 
- Lack of equipments by VUP sector staffs such as computers and other stationeries.

- Lack of information from VUP coordination

- Insufficient fertilizer inputs for small scale farmers

- Forestry Master plans are not being implemented due to the fact that, Districts have not yet received permission to operate government forests

\section{Key recommendations}

Both OCIR thé and OCIR Café should develop a mechanism for distribution of fertilizers on credit to small scale farmers.

Sensitization of stakeholders meetings organized to tell them about more existing opportunities in Western Investment Corporation 


\section{EDPRS RESULTS AND POLICY MATRIX TRAFFIC LIGHT SCORING}

\begin{tabular}{|c|c|c|c|c|c|c|c|c|}
\hline $\begin{array}{l}\text { EDPRS } \\
\text { STRATEGIC } \\
\text { OBJECTIVES }\end{array}$ & $\begin{array}{l}\text { EDPRS } \\
\text { STRATEGIC } \\
\text { OUTCOMES } \\
\text { (Results) }\end{array}$ & INDICATORS & \multicolumn{3}{|c|}{ EXPECTED PERFORMANCE } & \multicolumn{3}{|c|}{ PUBLIC POLICY ACTIONS } \\
\hline & & & & & & Policy Action & Year & scoring \\
\hline & & & Baseline 2006 & Targets 2008 & $\begin{array}{l}\text { Traffic light } \\
\text { scoring and } \\
\text { actual } \\
\text { performance } \\
\end{array}$ & & 2008 & \\
\hline & \multicolumn{5}{|c|}{ Key Strategic Results } & & & \\
\hline & & \multicolumn{4}{|c|}{ National Strategic Outcomes } & & & \\
\hline & $\begin{array}{l}\text { Increased GDP } \\
\text { Growth }\end{array}$ & GDP Growth rate & 6,5 & 7,1 & 11.2 & & & \\
\hline & \multirow[t]{3}{*}{$\begin{array}{l}\text { Reduced income } \\
\text { poverty and } \\
\text { inequality }\end{array}$} & $\begin{array}{l}\% \text { share of } \\
\text { population below } \\
\text { poverty }\end{array}$ & $56,9 \%$ & & $56,9 \%$ & & & \\
\hline & & Gini Coeffecient & 0,51 & & 0,51 & & & \\
\hline & & $\begin{array}{lr}\% \text { share } & \text { of } \\
\text { Population } & \text { in } \\
\text { extreme poverty }\end{array}$ & $36,9 \%$ & & $36,9 \%$ & & & \\
\hline & \multirow{5}{*}{$\begin{array}{l}\text { Improved } \\
\text { Human } \\
\text { Development }\end{array}$} & $\begin{array}{l}\text { (a) Total Fertility } \\
\text { rate }\end{array}$ & 6,1 & & 6,1 & & & \\
\hline & & $\begin{array}{l}\text { (b) Infant } \\
\text { mortality rate (per } \\
1000 \text { live births) }\end{array}$ & 86 & & 86 & & & \\
\hline & & $\begin{array}{l}\text { (c) Marternal } \\
\text { Mortality rate }\end{array}$ & 750 & & 750 & & & \\
\hline & & $\begin{array}{l}\text { (d) Literacy rate: } \\
\text { males }\end{array}$ & $65 \%$ & & $65 \%$ & & & \\
\hline & & females & $60 \%$ & & $60 \%$ & & & \\
\hline \\
\hline
\end{tabular}

CInternational Monetary Fund. Not for Redistribution 


\begin{tabular}{|c|c|c|c|c|c|c|c|c|}
\hline \multirow{2}{*}{$\begin{array}{l}\text { EDPRS } \\
\text { STRATEGIC } \\
\text { OBJECTIVES }\end{array}$} & \multirow{3}{*}{$\begin{array}{l}\text { EDPRS } \\
\text { STRATEGIC } \\
\text { OUTCOMES } \\
\text { (Results) }\end{array}$} & \multirow[t]{3}{*}{ INDICATORS } & & \multirow{2}{*}{\multicolumn{3}{|c|}{ PUBLIC POLICY ACTIONS }} \\
\hline & & & \multicolumn{3}{|c|}{ EXPECTED PERFORMANCE } & & & \\
\hline & & & & & & \multirow[t]{2}{*}{$\begin{array}{l}\text { EDPRS Described } \\
\text { Policy Action }\end{array}$} & \multirow[t]{2}{*}{$\begin{array}{c}\text { Key Policy Benchmarks/Outputs by } \\
\text { Year }\end{array}$} & \multirow[t]{2}{*}{$\begin{array}{ll}\text { Traffic light } \\
\text { scoring }\end{array}$} \\
\hline & & & Baseline 2006 & Targets 2008 & $\begin{array}{l}\text { Traffic light } \\
\text { scoring and } \\
\text { actual } \\
\text { performance } \\
\end{array}$ & & & \\
\hline \multirow{6}{*}{$\begin{array}{l}1 . \quad \text { Increased } \\
\text { Economic } \\
\text { Growth }\end{array}$} & & & & oeconomic stab & ty consistent $n$ & private sector led grow & & \\
\hline & \multirow[t]{5}{*}{$\begin{array}{l}1.1 \quad \text { Prudent } \\
\text { macro economic } \\
\text { management } \\
\text { ensured }\end{array}$} & \multirow[t]{2}{*}{$\begin{array}{l}1.1 .1 \quad \text { Net } \\
\text { domestic } \\
\text { financing (as \% of } \\
\text { GDP) }\end{array}$} & \multirow[t]{2}{*}{$<0.5$} & \multirow[t]{2}{*}{$<0.5$} & \multirow[t]{2}{*}{$(-) 3.3 \%$} & \multirow[t]{2}{*}{$\begin{array}{l}\text { Expenditures } \\
\text { Align Ministry } \\
\text { spending with the } \\
\text { MTEF and Strategic } \\
\text { plan }\end{array}$} & $\begin{array}{l}\text { Prepare and implement } 2009 \\
\text { budget in line with the EDPRS } \\
\text { priorities and the medium term } \\
\text { macro framework }\end{array}$ & $\begin{array}{l}\text { Fully } \\
\text { implemented }\end{array}$ \\
\hline & & & & & & & $\begin{array}{l}\text { Implement actions to widen the tax } \\
\text { base. }\end{array}$ & $\begin{array}{l}\text { Fully } \\
\text { implemented }\end{array}$ \\
\hline & & $\begin{array}{l}1.1 .2 \text { Increase of } \\
\text { tax revenue to } \\
\text { GDP ratio } \\
\text { (indicative) }\end{array}$ & 0.2 & 0.2 & 0.4 & $\begin{array}{l}\text { Revenues: Implement } \\
\text { new tax policy } \\
\text { measures as per } 2007 \\
\text { tax policy and } \\
\text { strategy }\end{array}$ & $\begin{array}{l}\text { Develop a comprehensive } \\
\text { compliance program to identify } \\
\text { risks of non compliance, including } \\
\text { enhancing the SIGTAS computer } \\
\text { system to strengthen information } \\
\text { analysis. } \\
\text { Undertake risk based audits }\end{array}$ & $\begin{array}{l}\text { Fully } \\
\text { implemented }\end{array}$ \\
\hline & & $\begin{array}{l}\text { 1.1.3 Inflation rate } \\
\text { (core inflation } \\
\text { annual \% change, } \\
\text { end period basis) }\end{array}$ & 11,9 & Single digit & $15.4 \%$ & $\begin{array}{l}\text { Set monetary policy } \\
\text { to retain single digit } \\
\text { inflation. Use reserve } \\
\text { money growth as } \\
\text { policy instrument }\end{array}$ & $\begin{array}{l}\text { BNR to use policy instruments: } \\
\text { Reserve requirement; Foreign } \\
\text { exchange sales; and Treasury bill } \\
\text { sales to mop up excess liquidity } \\
\text { such that monetary policy targets } \\
\text { are achieved. } \\
\text { In addition supply side constraints } \\
\text { will also be dealt by concerned } \\
\text { sectors (i.e. agriculture, energy). } \\
\text { See policy actions for relevant } \\
\text { sectors. }\end{array}$ & $\begin{array}{l}\text { Fully } \\
\text { implemented }\end{array}$ \\
\hline & & $\begin{array}{l}1.1 .4 \text { Insurance } \\
\text { coverage } \\
\text { (excluding } \\
\text { mutuelles } \\
\text { santé) } \quad(\% \text { de } \\
\text { GDP) } \quad \%\end{array}$ & $<1 \%$ & NA & $<1 \%$ & $\begin{array}{l}\text { Promote private } \\
\text { insurance }\end{array}$ & $\begin{array}{l}\text { Develop National Rural Insurance } \\
\text { Strategy and Capacity Building } \\
\text { Plan }\end{array}$ & $\begin{array}{l}\text { Fully } \\
\text { implemented }\end{array}$ \\
\hline
\end{tabular}




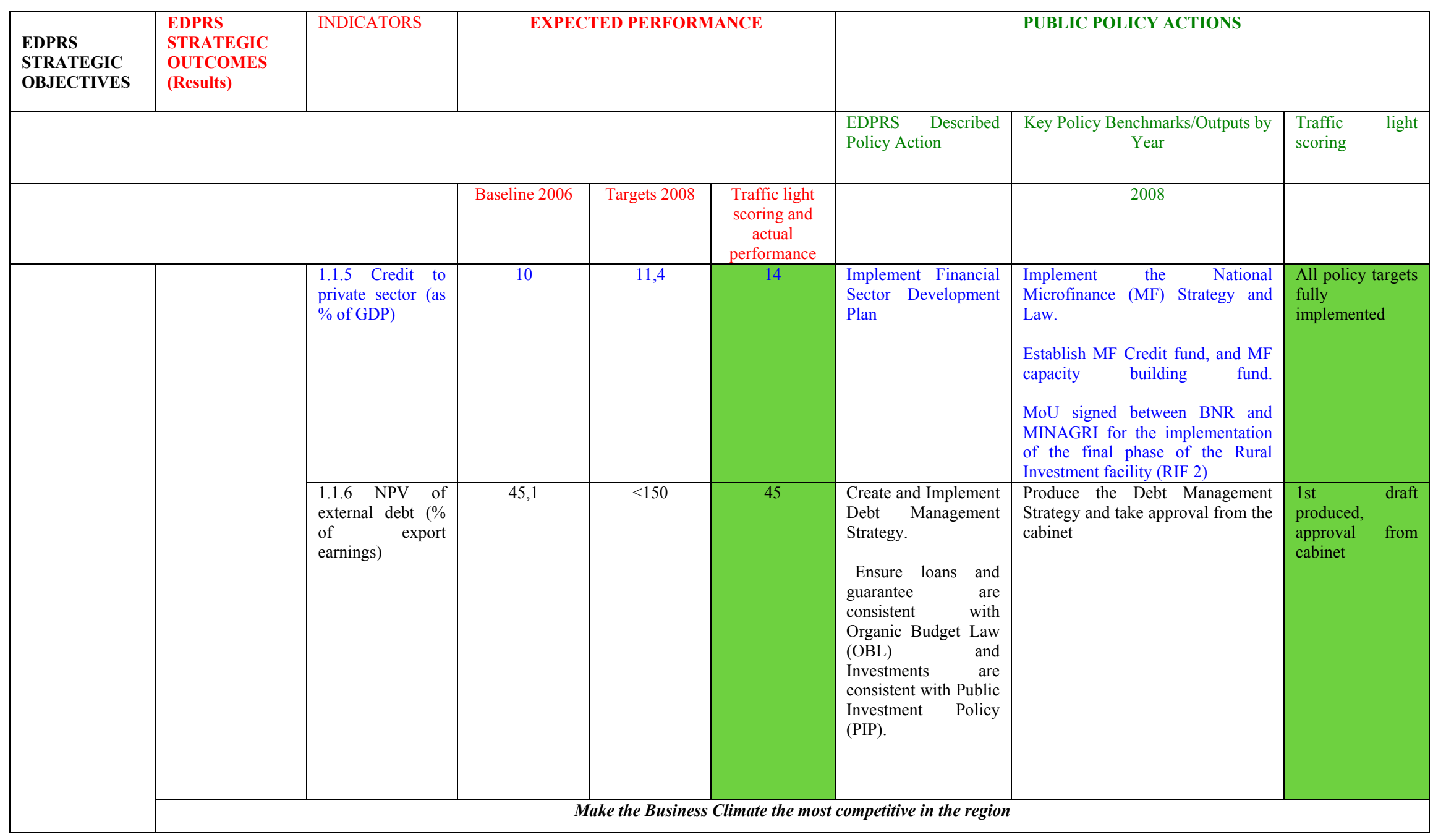




\begin{tabular}{|c|c|c|c|c|c|c|c|c|}
\hline $\begin{array}{l}\text { EDPRS } \\
\text { STRATEGIC } \\
\text { OBJECTIVES }\end{array}$ & $\begin{array}{l}\text { EDPRS } \\
\text { STRATEGIC } \\
\text { OUTCOMES } \\
\text { (Results) }\end{array}$ & INDICATORS & \multicolumn{3}{|c|}{ EXPECTED PERFORMANCE } & \multicolumn{3}{|c|}{ PUBLIC POLICY ACTIONS } \\
\hline & & & & & & Policy Action & Year & $\begin{array}{l}\text { Iraftic light } \\
\text { scoring }\end{array}$ \\
\hline & & & Baseline 2006 & Targets 2008 & $\begin{array}{l}\text { Traffic light } \\
\text { scoring and } \\
\text { actual } \\
\text { performance }\end{array}$ & & 2008 & \\
\hline & $\begin{array}{l}1.2 \quad \text { Enhanced } \\
\text { business climate }\end{array}$ & $\begin{array}{l}\text { 1.2.1 Ranking in } \\
\text { Doing Business }\end{array}$ & 158 & 154 & 139 & $\begin{array}{l}\text { Implement strategies } \\
\text { to improve business } \\
\text { and investment } \\
\text { climate in Rwanda }\end{array}$ & $\begin{array}{l}\text { Establish commercial registration } \\
\text { agency. } \\
\text { Legislate Bills on Companies, } \\
\text { Contracts, Secured Transactions, } \\
\text { Business Registration and } \\
\text { Insolvency. } \\
\text { Implement RADDEX system to } \\
\text { ease cross-border trade with } \\
\text { Tanzania and Uganda. } \\
\begin{array}{l}\text { Levy taxes on imports at FOB } \\
\text { values. }\end{array}\end{array}$ & $\begin{array}{lr}\text { Target } & \text { fully } \\
\text { achieved } & \text { and } \\
\text { exceeded } & \end{array}$ \\
\hline & & $\begin{array}{l}1.2 .2 \text { Score of } \\
\text { Investor } \\
\text { Perceptions of } \\
\text { regulatory issues, } \\
\text { licensing burden, } \\
\text { corruption and } \\
\text { dispute resolution }\end{array}$ & $\begin{array}{l}\text { Baseline data } \\
\text { not available }\end{array}$ & $\begin{array}{l}\text { Baseline data } \\
\text { not available }\end{array}$ & 79 & $\begin{array}{l}\text { Create a condusive } \\
\text { environment for both } \\
\text { local and foreign } \\
\text { investors }\end{array}$ & $\begin{array}{l}\text { Business Licensing reform } \\
\text { Identification and approval of } \\
\text { quick win reforms on licensing by } \\
\text { Cabinet }\end{array}$ & $\begin{array}{l}\text { An inventory of } \\
189 \text { licenses has } \\
\text { been created } \\
\text { consultation } \\
\text { taking place }\end{array}$ \\
\hline & & $\begin{array}{l}\text { 1.2.3 Percentage } \\
\text { of investment to } \\
\text { GDP }\end{array}$ & $16 \%$ & $17 \%$ & $18 \%$ & & $\begin{array}{l}\text { Develop Industrial Master Plan } \\
\text { (developed by MINICOM) }\end{array}$ & $\begin{array}{l}\text { Fully } \\
\text { implemented }\end{array}$ \\
\hline
\end{tabular}




\begin{tabular}{|c|c|c|c|c|c|c|c|c|}
\hline \multirow{2}{*}{$\begin{array}{l}\text { EDPRS } \\
\text { STRATEGIC } \\
\text { OBJECTIVES }\end{array}$} & $\begin{array}{l}\text { EDPRS } \\
\text { STRATEGIC } \\
\text { OUTCOMES } \\
\text { (Results) }\end{array}$ & \multirow[t]{2}{*}{ INDICATORS } & \multicolumn{3}{|c|}{ EXPECTED PERFORMANCE } & \multicolumn{3}{|c|}{ PUBLIC POLICY ACTIONS } \\
\hline & & & & & & $\begin{array}{l}\text { EDPRS Described } \\
\text { Policy Action }\end{array}$ & $\begin{array}{c}\text { Key Policy Benchmarks/Outputs by } \\
\text { Year }\end{array}$ & $\begin{array}{ll}\text { Traffic } & \text { light } \\
\text { scoring } & \end{array}$ \\
\hline & & & Baseline 2006 & Targets 2008 & $\begin{array}{l}\text { Traffic light } \\
\text { scoring and } \\
\text { actual } \\
\text { performance } \\
\end{array}$ & & 2008 & \\
\hline & \multirow[t]{4}{*}{$\begin{array}{l}1.3 \quad \text { Economic } \\
\text { infrastructure } \\
\text { built }\end{array}$} & $\begin{array}{l}\text { 1.3.1 Number of } \\
\text { electricity } \\
\text { subsciptions }\end{array}$ & 91332 & 100000 & 110000 & $\begin{array}{l}\text { Increase Access to } \\
\text { Electricity for } \\
\text { Enterprises and } \\
\text { Households to serve } \\
\text { as an engine for } \\
\text { socio-economic } \\
\text { development }\end{array}$ & $\begin{array}{l}\text { Update national energy } \\
\text { policyElectricity network expansion } \\
\text { rollout program is initiated by } \\
\text { MININFRA Prepare strategic note } \\
\text { on electricity tariff, taxes and } \\
\text { incentives (Mininfra)Sign MoU } \\
\text { with Development Partners as 1st } \\
\text { output of SWAp }\end{array}$ & $\begin{array}{l}\text { All policy targets } \\
\text { fully } \\
\text { implemented }\end{array}$ \\
\hline & & $\begin{array}{l}1.3 .2 \text { MW of } \\
\text { electricity } \\
\text { installed }\end{array}$ & $45 \mathrm{MW}$ & $50 \mathrm{MW}$ & $74.445 \mathrm{MW}$ & & $\begin{array}{l}\text { Sign contract between Mininfra and } \\
\text { at least } 2 \text { IPPs for generation of } \\
\text { electricity } \\
\text { Submit Laws on Electricity and Gas } \\
\text { to parliament }\end{array}$ & $\begin{array}{l}\text { All policy targets } \\
\text { fully } \\
\text { implemented }\end{array}$ \\
\hline & & \multirow[t]{2}{*}{$\begin{array}{l}1.3 .3 \text { Percentage } \\
\text { of Classified } \\
\text { National Road } \\
\text { network in good } \\
\text { condition }\end{array}$} & \multirow[t]{2}{*}{$11 \%$} & \multirow[t]{2}{*}{$16 \%$} & \multirow[t]{2}{*}{$18 \%$} & $\begin{array}{lr}\text { Initiate } & \text { the } \\
\text { rehabilitation } & \text { and } \\
\text { maintenance } & \text { of } \\
\text { classified } & \text { road } \\
\text { network } & \end{array}$ & $\begin{array}{l}\begin{array}{l}\text { Adopt the Transport Policy and } \\
\text { Road Maintenance Strategy }\end{array} \\
\text { Commence and complete Periodic } \\
\text { Maintenance of } 80 \mathrm{~km} \text { of the } 780 \mathrm{~km} \\
\text { of National Earth Roads }\end{array}$ & $\begin{array}{l}\text { All policy targets } \\
\text { fully } \\
\text { implemented }\end{array}$ \\
\hline & & & & & & 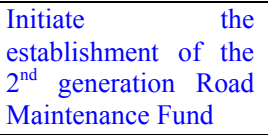 & $\begin{array}{l}\text { Draft strategic proposal to Cabinet } \\
\text { for the second generation Road } \\
\text { Maintenance Fund (MININFRA \& } \\
\text { MINICOM) }\end{array}$ & $\begin{array}{l}\text { All policy targets } \\
\text { fully } \\
\text { implemented }\end{array}$ \\
\hline
\end{tabular}




\begin{tabular}{|c|c|c|c|c|c|c|c|c|}
\hline \multirow{2}{*}{$\begin{array}{l}\text { EDPRS } \\
\text { STRATEGIC } \\
\text { OBJECTIVES }\end{array}$} & $\begin{array}{l}\text { EDPRS } \\
\text { STRATEGIC } \\
\text { OUTCOMES } \\
\text { (Results) }\end{array}$ & \multirow[t]{2}{*}{ INDICATORS } & \multicolumn{3}{|c|}{ EXPECTED PERFORMANCE } & \multicolumn{3}{|c|}{ PUBLIC POLICY ACTIONS } \\
\hline & & & & & & \multirow{2}{*}{$\begin{array}{l}\text { EDPRS Described } \\
\text { Policy Action }\end{array}$} & \multirow{2}{*}{$\begin{array}{c}\text { Key Policy Benchmarks/Outputs by } \\
\text { Year }\end{array}$} & \multirow{2}{*}{$\begin{array}{ll}\text { Traffic } \quad \text { light } \\
\text { scoring }\end{array}$} \\
\hline & & & Baseline 2006 & Targets 2008 & $\begin{array}{l}\text { Traffic light } \\
\text { scoring and } \\
\text { actual } \\
\text { performance } \\
\end{array}$ & & & \\
\hline & & $\begin{array}{lr}1.3 .4 & \text { Percentage } \\
\text { of } & \text { Classified } \\
\text { District } & \text { Road } \\
\text { network in } & \text { good } \\
\text { condition } & \end{array}$ & $15 \%$ & $22 \%$ & $\begin{array}{l}\text { Information } \\
\text { unvailable } \\
\text { due to non } \\
\text { submission of } \\
\text { reports by } \\
\text { Districts }\end{array}$ & $\begin{array}{l}\text { Establish multi- } \\
\text { annual road } \\
\text { maintenance contracts } \\
\text { to be managed by } \\
\text { Districts }\end{array}$ & $\begin{array}{l}\text { Districts sign Multi Annual (3 year) } \\
\text { Output and Performance Based } \\
\text { Road Contracts (OPBRC's) with at } \\
\text { least } 2 \text { contractors } \\
\text { Adopt a District/Rural Road } \\
\text { Maintenance and Decentralisation } \\
\text { Strategy as part of the Road } \\
\text { Maintenance Strategy }\end{array}$ & $\begin{array}{l}\text { All policy targets } \\
\text { fully } \\
\text { implemented }\end{array}$ \\
\hline & & $\begin{array}{l}1.3 .5 \quad \text { (i) ICT } \\
\text { composite } \\
\text { network coverage }\end{array}$ & $75 \%$ & NA & $90 \%$ & Develop ICT & $\begin{array}{l}\text { Develop regulatory framework for } \\
\text { ICT }\end{array}$ & $\begin{array}{l}\text { Fully } \\
\text { implemented }\end{array}$ \\
\hline & & $\begin{array}{l}\text { (ii)Number } \begin{array}{r}\text { of } \\
\text { mobile phone } \\
\text { users }\end{array} \\
\end{array}$ & & NA & $1,322,637$ & & & \\
\hline & $\begin{array}{l}1.4 \text { Increased } \\
\text { contribution of } \\
\text { strategic exports } \\
\text { to GDP }\end{array}$ & $\begin{array}{lr}1.4 .1 & \text { Revenue } \\
\text { from } & \text { strategic } \\
\text { exports } & \text { (tea, } \\
\text { coffee, } & \\
\text { horticulture, hides } \\
\& \quad \text { skins, } \\
\text { minerals), in US\$ } \\
\text { million }\end{array}$ & 121 & 163,1 & 185 & $\begin{array}{l}\text { Develop strategies to } \\
\text { increase production, } \\
\text { quality and } \\
\text { management of key } \\
\text { exports }\end{array}$ & $\begin{array}{l}\text { Develop Production and Export } \\
\text { diversification Strategy. }\end{array}$ & $\begin{array}{l}\text { Fully } \\
\text { implemented }\end{array}$ \\
\hline & & $\begin{array}{l}1.4 .2 \text { Revenue } \\
\text { from tourism, in } \\
\text { US\$ million }\end{array}$ & 42 & 56 & 208 & Diversify tourism & $\begin{array}{l}\text { Review and develop the Tourism } \\
\text { master plan (ORTPN, MINICOM) }\end{array}$ & \\
\hline & & & & & & $\begin{array}{lr}\begin{array}{l}\text { Construct } \\
\text { rehabilitate }\end{array} & \text { and/or } \\
\text { museums } & \\
\end{array}$ & 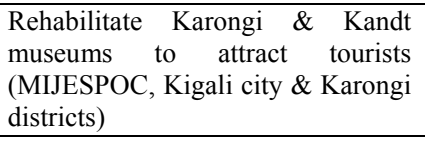 & \\
\hline & & & & 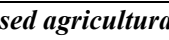 & 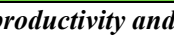 & vironmental manage & & \\
\hline
\end{tabular}

CInternational Monetary Fund. Not for Redistribution 


\begin{tabular}{|c|c|c|c|c|c|c|c|c|}
\hline \multirow{2}{*}{$\begin{array}{l}\text { EDPRS } \\
\text { STRATEGIC } \\
\text { OBJECTIVES }\end{array}$} & $\begin{array}{l}\text { EDPRS } \\
\text { STRATEGIC } \\
\text { OUTCOMES } \\
\text { (Results) }\end{array}$ & \multirow[t]{2}{*}{ INDICATORS } & \multicolumn{3}{|c|}{ EXPECTED PERFORMANCE } & \multicolumn{3}{|c|}{ PUBLIC POLICY ACTIONS } \\
\hline & & & & & & $\begin{array}{l}\text { EDPRS Described } \\
\text { Policy Action }\end{array}$ & $\begin{array}{c}\text { Key Policy Benchmarks/Outputs by } \\
\text { Year }\end{array}$ & $\begin{array}{ll}\text { Traffic } & \text { light } \\
\text { scoring } & \end{array}$ \\
\hline & & & Baseline 2006 & Targets 2008 & $\begin{array}{l}\text { Traffic light } \\
\text { scoring and } \\
\text { actual } \\
\text { performance } \\
\end{array}$ & & 2008 & \\
\hline & $\begin{array}{l}\text { 1.5 Increased } \\
\text { agricultural } \\
\text { productivity }\end{array}$ & $\begin{array}{l}\text { 1.5.1 Percentage } \\
\text { of land area } \\
\text { protected against } \\
\text { soil erosion }\end{array}$ & $40 \%$ & $45 \%$ & $44.5 \%$ & $\begin{array}{lr}\text { Develop } & \text { and } \\
\text { implement } & \\
\text { programmes } & \text { for } \\
\text { construction } & \text { and } \\
\text { rehabilitation } & \text { of } \\
\text { (progressive } & \text { \& } \\
\text { radical) terraces } & \text { and } \\
\text { erosion control } & \end{array}$ & $\begin{array}{l}\text { Complete feasibility studies for at } \\
\text { least } 4 \text { out of } 34 \text { sites for watershed } \\
\text { management Including an } \\
\text { assessment of existing pilots as well } \\
\text { as a mapping of areas that need } \\
\text { protection by watershed } \\
\text { management and terracing }\end{array}$ & $\begin{array}{l}\text { A total of } \\
12.920 \text { ha of } \\
\text { terraces were } \\
\text { constructed } \\
\text { Feasibility study } \\
\text { and details } \\
\text { designed were } \\
\text { commissioned } \\
\text { for } 8 \text { sites (32 } \\
\text { pre-feasibility } \\
\text { studies have been } \\
\text { completed) }\end{array}$ \\
\hline & & $\begin{array}{lr}1.5 .2 \text { Area } & \text { of } \\
\text { marshland } & \\
\text { developed } & \text { for } \\
\text { agricultural } & \text { use } \\
\text { (Has) } & \\
\end{array}$ & 11000 & 12000 & 12092 & $\begin{array}{l}\text { Develop marshland } \\
\text { with pre-feasibility } \\
\text { studies and compliant } \\
\text { with environmental } \\
\text { guidelines }\end{array}$ & $\begin{array}{l}\text { Develop } \\
\text { Management Framework for } \\
\text { Marshlands, including format and } \\
\text { implementation schedule }\end{array}$ & $\begin{array}{l}\text { Fully } \\
\text { implemented }\end{array}$ \\
\hline & & $\begin{array}{lr}1.5 .3 & \text { Proportion } \\
\text { of } & \text { farming } \\
\text { households } & \text { using } \\
\text { improved } & \text { farm } \\
\text { methods } & \end{array}$ & $\begin{array}{l}\text { Farmers using } \\
\text { Chemical } \\
\text { fertilizer } 12 \% \text {; } \\
\text { Organic } \\
\text { fertilizer } 7 \%\end{array}$ & $\begin{array}{l}\text { Farmers } \\
\text { using } \\
\text { Chemical } \\
\text { fertilizer } \\
15 \% \text {; Organic } \\
\text { fertilizer } 10 \%\end{array}$ & $\begin{array}{l}\text { NA (Unable } \\
\text { to measure the } \\
\text { use of } \\
\text { fertilizer at } \\
\text { the HH level } \\
\text { annually) }\end{array}$ & $\begin{array}{ll}\text { Operationalize } & \\
\text { National } & \text { Input } \\
\text { Strategy } & \end{array}$ & $\begin{array}{l}\text { Implement fertilizer strategy with a } \\
\text { clarification of public and private } \\
\text { roles. } \\
\text { Develop Seed Law }\end{array}$ & $\begin{array}{l}\text { All policy targets } \\
\text { fully } \\
\text { implemented }\end{array}$ \\
\hline
\end{tabular}




\begin{tabular}{|c|c|c|c|c|c|c|c|c|}
\hline \multirow{2}{*}{$\begin{array}{l}\text { EDPRS } \\
\text { STRATEGIC } \\
\text { OBJECTIVES }\end{array}$} & \multirow{2}{*}{$\begin{array}{l}\text { EDPRS } \\
\text { STRATEGIC } \\
\text { OUTCOMES } \\
\text { (Results) }\end{array}$} & \multirow[t]{2}{*}{ INDICATORS } & \multirow{2}{*}{\multicolumn{3}{|c|}{ EXPECTED PERFORMANCE }} & \multirow{2}{*}{\multicolumn{3}{|c|}{ PUBLIC POLICY ACTIONS }} \\
\hline & & & & & & & & \\
\hline & & & & & & \multirow[t]{2}{*}{$\begin{array}{l}\text { EDPRS Described } \\
\text { Policy Action }\end{array}$} & \multirow[t]{2}{*}{$\begin{array}{c}\text { Key Policy Benchmarks/Outputs by } \\
\text { Year }\end{array}$} & \multirow[t]{2}{*}{$\begin{array}{ll}\text { Traffic } & \text { light } \\
\text { scoring } & \end{array}$} \\
\hline & & & Baseline 2006 & Targets 2008 & $\begin{array}{l}\text { Traffic light } \\
\text { scoring and } \\
\text { actual } \\
\text { performance }\end{array}$ & & & \\
\hline & & $\begin{array}{lr}1.5 .4 & \text { Farm } \\
\text { households } & \text { to } \\
\text { extension ratio }\end{array}$ & $1: 3,000$ & $1: 2,900$ & $1: 2,218$ & $\begin{array}{l}\text { Roll-out private and } \\
\text { public extensionists } \\
\text { across Districts }\end{array}$ & $\begin{array}{l}\begin{array}{l}\text { Finalize and Disseminate extension } \\
\text { strategy }\end{array} \\
\text { Implement Decentralized National } \\
\text { Agricultural Extension Strategy in } 6 \\
\text { pilot districts }\end{array}$ & $\begin{array}{l}\text { All policy targets } \\
\text { fully } \\
\text { implemented }\end{array}$ \\
\hline & & $\begin{array}{l}\text { 1.5.5 Production } \\
\text { in MT of key food } \\
\text { security and } \\
\text { export crops }\end{array}$ & $\begin{array}{l}\text { Maize: } 91,813 \\
\text { Rice: } 62,932 \\
\text { Wheat: } 19,549 \\
\text { Tea (grean } \\
\text { leaf): } 73,008\end{array}$ & $\begin{array}{c}\text { Maize: } \\
\text { 101,700 Rice: } \\
\text { 66,700 Wheat } \\
\text { 24,200 Tea: } \\
\text { 77,400 }\end{array}$ & $\begin{array}{c}\text { Maize: } \\
\text { 101,700 Rice: } \\
\text { 66,700 Wheat } \\
\text { 24,200 Tea: } \\
\text { 77,400 }\end{array}$ & $\begin{array}{l}\text { Improve production } \\
\text { of key crops through } \\
\text { multiplication centers } \\
\text { and mother gardens } \\
\text { for multiplication in } \\
\text { districts and sectors }\end{array}$ & $\begin{array}{l}\text { Establish demonstration sites and } \\
\text { farmer field schools for key crops } \\
\text { in appropriate districts. Mapping of } \\
\text { sectors where farmer field schools } \\
\text { can be established. Support } \\
\text { feasibility studies of two new tea } \\
\text { factories. }\end{array}$ & $\begin{array}{l}\text { All policy targets } \\
\text { fully } \\
\text { implemented }\end{array}$ \\
\hline & & $\begin{array}{l}\text { 1.5.6 Percentage } \\
\text { livestock in } \\
\text { intensive systems }\end{array}$ & 16 & 30,7 & NA & $\begin{array}{l}\text { Develop and publish } \\
\text { a clear policy on } \\
\text { genetic improvement } \\
\text { of livestock }\end{array}$ & $\begin{array}{l}\text { Develop and publish a clear policy } \\
\text { on animal nutrition }\end{array}$ & $\begin{array}{l}\text { All policy targets } \\
\text { fully } \\
\text { implemented }\end{array}$ \\
\hline & & & & & & $\begin{array}{l}\text { Complete study on } \\
\text { competitiveness of } \\
\text { milk commodity } \\
\text { chain }\end{array}$ & $\begin{array}{l}\text { Develop and publish a clear policy } \\
\text { on animal disease control }\end{array}$ & $\begin{array}{l}\text { All policy targets } \\
\text { fully } \\
\text { implemented }\end{array}$ \\
\hline
\end{tabular}




\begin{tabular}{|c|c|c|c|c|c|c|c|c|}
\hline \multirow{2}{*}{$\begin{array}{l}\text { EDPRS } \\
\text { STRATEGIC } \\
\text { OBJECTIVES }\end{array}$} & \multirow{2}{*}{$\begin{array}{l}\text { EDPRS } \\
\text { STRATEGIC } \\
\text { OUTCOMES } \\
\text { (Results) }\end{array}$} & \multirow{2}{*}{ INDICATORS } & \multicolumn{3}{|c|}{ EXPECTED PERFORMANCE } & \multicolumn{3}{|c|}{ PUBLIC POLICY ACTIONS } \\
\hline & & & & & & \multirow[t]{2}{*}{$\begin{array}{l}\text { EDPRS Described } \\
\text { Policy Action }\end{array}$} & \multirow[t]{2}{*}{$\begin{array}{c}\text { Key Policy Benchmarks/Outputs by } \\
\text { Year }\end{array}$} & \multirow[t]{2}{*}{$\begin{array}{ll}\text { Traffic } & \text { light } \\
\text { scoring } & \end{array}$} \\
\hline & & & Baseline 2006 & Targets 2008 & $\begin{array}{l}\text { Traffic light } \\
\text { scoring and } \\
\text { actual } \\
\text { performance }\end{array}$ & & & \\
\hline & \multirow[t]{5}{*}{$\begin{array}{l}\text { 1.6 Optimal } \\
\text { utilisation of } \\
\text { natural } \\
\text { resources }\end{array}$} & $\begin{array}{l}\text { 1.6.1 Percentage } \\
\text { of national forest } \\
\text { cover }\end{array}$ & $20,00 \%$ & $20,70 \%$ & $21,00 \%$ & $\begin{array}{ll}\text { Increase } & \text { national } \\
\text { forest cover } & \end{array}$ & $\begin{array}{l}\text { Complete and adopt National Forest } \\
\text { inventory and District management } \\
\text { plans (MINITERE and NAFA) }\end{array}$ & 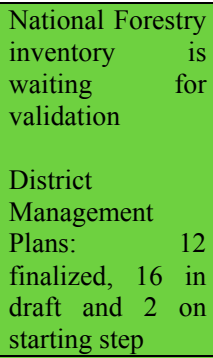 \\
\hline & & $\begin{array}{l}1.6 .2 \text { Percentage } \\
\text { of area of } \\
\text { privately owned } \\
\text { land held under } \\
\text { written title }\end{array}$ & $1 \%$ & $3 \%$ & $1.26 \%$ & $\begin{array}{lr}\text { Protect land rights } \\
\text { and simplify land } \\
\text { administration r to } \\
\text { facilitate investments } \\
\text { in land }\end{array}$ & $\begin{array}{l}\text { Develop and produce aerial } \\
\text { photography and digital ortho maps } \\
\text { to guide systematic land registration } \\
\text { (National Land Centre) }\end{array}$ & $\begin{array}{l}70 \% \text { of the whole } \\
\text { country }\end{array}$ \\
\hline & & $\begin{array}{l}\text { 1.6.3 Proportion } \\
\text { issued land titles } \\
\text { owned by women }\end{array}$ & $0 \%$ & $2 \%$ & $0.02 \%$ & & $\begin{array}{l}\text { Complete and effect secondary } \\
\text { registration and manuals in support } \\
\text { of } 2005 \text { land law }\end{array}$ & $\begin{array}{l}\text { Fully } \\
\text { implemented }\end{array}$ \\
\hline & & \multirow{2}{*}{$\begin{array}{l}\text { 1.6.4 Area of land } \\
\text { protected to } \\
\text { maintain } \\
\text { biological } \\
\text { diversity currently }\end{array}$} & \multirow[t]{2}{*}{$8 \%$} & \multirow[t]{2}{*}{$8,40 \%$} & \multirow[t]{2}{*}{$8,5 \%$} & $\begin{array}{lr}\text { Map, assess } & \text { and } \\
\text { rehabilitate degraded } \\
\text { ecosystems } \\
\text { protected areas }\end{array}$ & Map and assess all degraded areas & $\begin{array}{l}\text { Inventory and } \\
\text { categorization }\end{array}$ \\
\hline & & & & & & & $\begin{array}{l}\text { Rehabilitate } 5 \% \text { of critically } \\
\text { degraded ecosystems (MINITERE } \\
\text { working with REMA) }\end{array}$ & $\begin{array}{l}\text { Many studies } \\
\text { were done }\end{array}$ \\
\hline \multirow{2}{*}{$\begin{array}{l}2 \text { Managing } \\
\text { population } \\
\text { growth rate and } \\
\text { enhacing }\end{array}$} & \multicolumn{8}{|c|}{ Improved population health for better quality of life } \\
\hline & $\begin{array}{l}2.1 \quad \text { Enhanced } \\
\text { famility planning }\end{array}$ & $\begin{array}{l}\text { Total Fertility } \\
\text { rate }\end{array}$ & 6,1 & & & & & \\
\hline
\end{tabular}

CInternational Monetary Fund. Not for Redistribution 


\begin{tabular}{|c|c|c|c|c|c|c|c|c|}
\hline \multirow{2}{*}{$\begin{array}{l}\text { EDPRS } \\
\text { STRATEGIC } \\
\text { OBJECTIVES }\end{array}$} & \multirow{2}{*}{$\begin{array}{l}\text { EDPRS } \\
\text { STRATEGIC } \\
\text { OUTCOMES } \\
\text { (Results) }\end{array}$} & \multirow[t]{2}{*}{ INDICATORS } & \multicolumn{3}{|c|}{ EXPECTED PERFORMANCE } & \multicolumn{3}{|c|}{ PUBLIC POLICY ACTIONS } \\
\hline & & & & & & \multirow{2}{*}{$\begin{array}{l}\text { EDPRS Described } \\
\text { Policy Action }\end{array}$} & \multirow{2}{*}{$\begin{array}{c}\text { Key Policy Benchmarks/Outputs by } \\
\text { Year }\end{array}$} & \multirow{2}{*}{$\begin{array}{ll}\text { Traffic } & \text { light } \\
\text { scoring } & \end{array}$} \\
\hline & & & Baseline 2006 & Targets 2008 & $\begin{array}{l}\text { Traffic light } \\
\text { scoring and } \\
\text { actual } \\
\text { performance } \\
\end{array}$ & & & \\
\hline \multirow[t]{8}{*}{$\begin{array}{c}\text { population } \\
\text { development }\end{array}$} & & $\begin{array}{lr}2.1 .1 & \text { Percentage } \\
\text { of women } & \text { aged } \\
15-49 & \text { using }\end{array}$ & $10 \%$ & $25 \%$ & $\begin{array}{l}27 \% \text { (DHS } \\
2007 / 8)\end{array}$ & Scale up FP services & $\begin{array}{l}\text { Population and family planning } \\
\text { promotion policy } \\
\text { including IEC strategy; }\end{array}$ & $\begin{array}{l}\text { Fully } \\
\text { implemented }\end{array}$ \\
\hline & & $\begin{array}{l}\text { modern } \\
\text { contraceptives }\end{array}$ & & & & & $\begin{array}{l}\text { Increase number of youth friendly } \\
\text { facilities to } 30 \% \text { of facilities }\end{array}$ & $\begin{array}{l}10 \text { centers now } \\
\text { have youth } \\
\text { friendly facilities }\end{array}$ \\
\hline & \multirow[t]{4}{*}{$\begin{array}{lr}2.2 & \text { Improved } \\
\text { health } & \text { and } \\
\text { nutrition } & \text { status }\end{array}$} & $\begin{array}{lr}\text { Under } 5 & \text { Child } \\
\text { mortality } & \text { rate } \\
\text { (per 1000) } & \end{array}$ & 152 & & & & & \\
\hline & & $\begin{array}{l}2.2 .1 \text { Percentage } \\
\text { of children fully } \\
\text { immunized }\end{array}$ & $75 \%$ & $80 \%$ & $\begin{array}{l}80.4 \% \text { (DHS } \\
2007 / 8)\end{array}$ & $\begin{array}{l}\text { Outreach services for } \\
\text { immunization at } \\
\text { community level }\end{array}$ & $\begin{array}{l}10 \% \text { of health centers do outreach } \\
\text { services for immunization }\end{array}$ & $\begin{array}{l}\text { Fully } \\
\text { implemented }\end{array}$ \\
\hline & & $\begin{array}{l}2.2 .2 \text { Percentage } \\
\text { of under five } \\
\text { children using } \\
\text { Insecticide } \\
\text { Treated Long } \\
\text { Lasting mosquito- } \\
\text { nets }\end{array}$ & $16 \%$ & $65 \%$ & $\begin{array}{l}60 \%(\text { DHS } \\
2007 / 8)\end{array}$ & $\begin{array}{l}\text { Free distribution of } \\
\text { ITLLN Nets to under } \\
\text { Five }\end{array}$ & $\begin{array}{l}\text { All IMIHIGO include use of bed } \\
\text { nets by children less than } 5 \text { as } \\
\text { performance indicator }\end{array}$ & $\begin{array}{l}20 \% \text { districts } \\
\text { have included } \\
\text { use of beds nets }\end{array}$ \\
\hline & & $\begin{array}{lr}2.2 .3 & \text { Percentage } \\
\text { of under } & \text { five } \\
\text { children } & \text { with } \\
\text { diarrhea } & \text { who } \\
\text { receive } & \text { ORT } \\
\text { treatment } & \text { within } \\
24 \text { hours } & \\
\end{array}$ & $22 \%$ & $30 \%$ & $45 \%$ & $\begin{array}{l}\text { Scale up community } \\
\text { treatment of diarrhea }\end{array}$ & $\begin{array}{l}\text { Guidelines for Districts published } \\
\text { and training of } 30 \text { Districts } \\
\text { conducted }\end{array}$ & $\begin{array}{l}\text { Guidelines } \\
\text { developed, } \\
\text { training in } 4 \\
\text { districts }\end{array}$ \\
\hline & & $\begin{array}{l}\text { Maternal } \\
\text { Mortality rate } \\
\text { (per 100,000 live } \\
\text { births) }\end{array}$ & 750 & & & & & \\
\hline & & $\begin{array}{l}2.2 .4 \text { Percentage } \\
\text { of assisted births } \\
\text { in an accredited } \\
\text { health facility }\end{array}$ & $28.2 \%$ & $35 \%$ & $62,8 \%$ & $\begin{array}{lr}\text { Develop incentive } \\
\text { mechanisms ro } \\
\text { increase deliveries in } \\
\text { health facilities }\end{array}$ & $\begin{array}{l}\text { Include assisted delivery in } 2008 \\
\text { IMIHIGO }\end{array}$ & Fully implemeted \\
\hline
\end{tabular}

(CInternational Monetary Fund. Not for Redistribution 


\begin{tabular}{|c|c|c|c|c|c|c|c|c|}
\hline \multirow{2}{*}{$\begin{array}{l}\text { EDPRS } \\
\text { STRATEGIC } \\
\text { OBJECTIVES }\end{array}$} & \multirow{2}{*}{$\begin{array}{l}\text { EDPRS } \\
\text { STRATEGIC } \\
\text { OUTCOMES } \\
\text { (Results) }\end{array}$} & \multirow[t]{2}{*}{ INDICATORS } & \multicolumn{3}{|c|}{ EXPECTED PERFORMANCE } & \multicolumn{3}{|c|}{ PUBLIC POLICY ACTIONS } \\
\hline & & & & $\begin{array}{l}\text { EDPRS Described } \\
\text { Policy Action }\end{array}$ & $\begin{array}{c}\text { Key Policy Benchmarks/Outputs by } \\
\text { Year }\end{array}$ & $\begin{array}{ll}\text { Traffic } & \text { light } \\
\text { scoring } & \end{array}$ \\
\hline & & & Baseline 2006 & Targets 2008 & $\begin{array}{l}\text { Traffic light } \\
\text { scoring and } \\
\text { actual } \\
\text { performance } \\
\end{array}$ & & 2008 & \\
\hline & & $\begin{array}{l}\text { Nutrition: } \% \text { of } \\
\text { children who } \\
\text { have chronic } \\
\text { malnutrition }\end{array}$ & $45 \%$ & & & & & \\
\hline & & $\begin{array}{l}2.2 .5 \text { Percentage } \\
\text { of children U5 } \\
\text { who receive } 2 \\
\text { doses of vitamin } \\
\text { A per year }\end{array}$ & & NA & NA & $\begin{array}{l}\text { Provide vitamin A } \\
\text { (micro-nutrient) } \\
\text { supplements through } \\
\mathrm{CHW} \text { and } \\
\text { immunization } \\
\text { services }\end{array}$ & $\begin{array}{l}\text { Design policy and management } \\
\text { tools and pilot in } 5 \text { Districts in each } \\
\text { province }\end{array}$ & $\begin{array}{l}\text { Fully } \\
\text { implemented }\end{array}$ \\
\hline & & $\begin{array}{lr}\text { HIV Control } \\
\text { (Prevalence } & \text { of } \\
\text { HIV among } & 15- \\
24 \text { years olds (as } \\
\text { proxy r for } \\
\text { incidence } & \text { in } \\
\text { general } & \\
\text { population)) } & \\
\end{array}$ & $1,05 \%$ & & & & & \\
\hline & & $\begin{array}{lr}2.2 .6 & \text { Condom } \\
\text { utilization } & \text { rate } \\
\text { amongst } & \text { youth } \\
(15-24) & \end{array}$ & $\begin{array}{l}26 \% \\
\text { women39\% } \\
\text { Male }\end{array}$ & NA & NA & $\begin{array}{l}\text { Strengthen medical } \\
\text { prevention measures } \\
\text { (VCT, } \\
\text { PMTCT,PIT,IST, } \\
\text { blood safety, post }\end{array}$ & $\begin{array}{l}\text { Provider Initiate Testing (PIT) } \\
\text { made a national policy and } \\
\text { implement in all District hospitals }\end{array}$ & $\begin{array}{l}\text { Policy developed } \\
\text { but Scale up PIT } \\
\text { will start in } 2009\end{array}$ \\
\hline & & & & & & $\begin{array}{lr}\text { exposure prophylaxis) } \\
\text { and non medicals } \\
\text { programs } \\
\text { particular emphasis to } \\
\text { most-at-risk groups } \\
\text { Improve } \\
\begin{array}{lr}\text { accessibility } \\
\text { quality the }\end{array} \\
\text { condoms, }\end{array}$ & $\begin{array}{l}\text { Neonatal and adults male } \\
\text { circumcision made a national policy }\end{array}$ & $\begin{array}{l}\text { The policy for } \\
\text { male } \\
\text { circumcision will } \\
\text { be integrated in } \\
\text { the National } \\
\text { Prevention } \\
\text { Policy not a } \\
\text { separate policy }\end{array}$ \\
\hline & & & & & & $\begin{array}{l}\text { increase demand and } \\
\text { address barriers to } \\
\text { condom utilization }\end{array}$ & $\begin{array}{l}\text { Intensify potential condom access } \\
\text { points in the community }\end{array}$ & $\begin{array}{l}\text { condoms widely } \\
\text { available }\end{array}$ \\
\hline
\end{tabular}




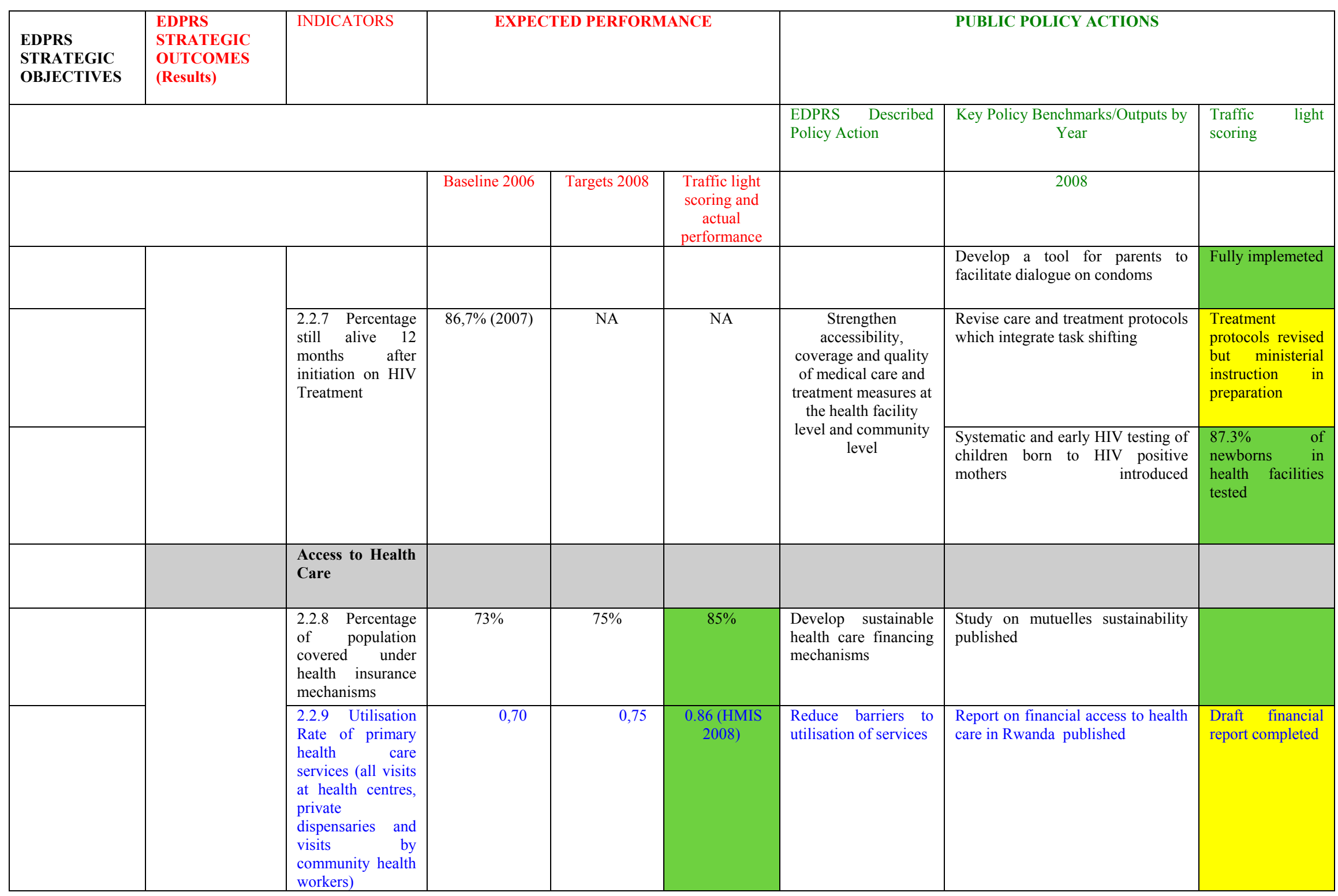




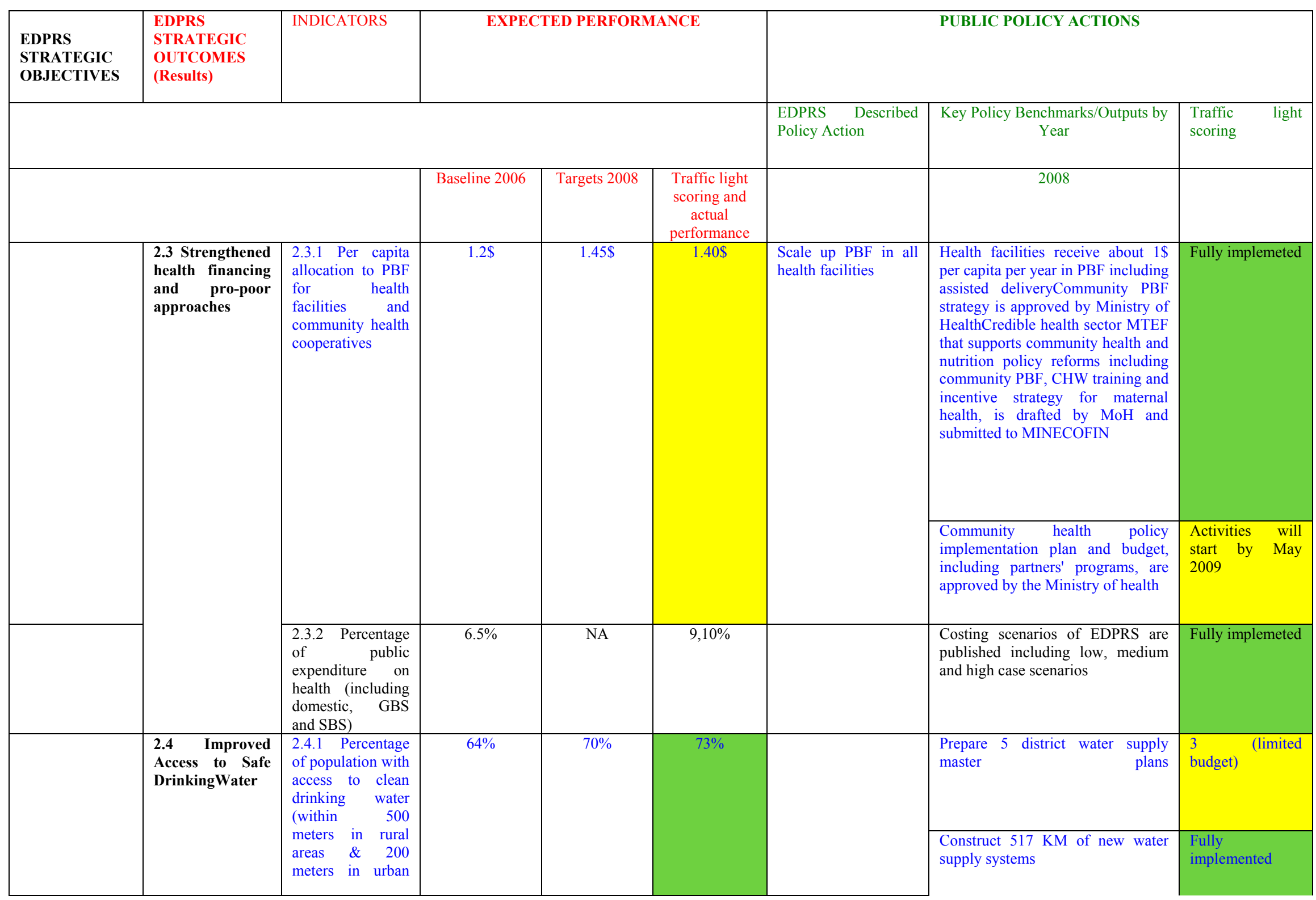




\begin{tabular}{|c|c|c|c|c|c|c|c|c|}
\hline \multirow{2}{*}{$\begin{array}{l}\text { EDPRS } \\
\text { STRATEGIC } \\
\text { OBJECTIVES }\end{array}$} & \multirow{2}{*}{$\begin{array}{l}\text { EDPRS } \\
\text { STRATEGIC } \\
\text { OUTCOMES } \\
\text { (Results) }\end{array}$} & \multirow[t]{2}{*}{ INDICATORS } & \multicolumn{3}{|c|}{ EXPECTED PERFORMANCE } & \multicolumn{3}{|c|}{ PUBLIC POLICY ACTIONS } \\
\hline & & & & & & \multirow{2}{*}{$\begin{array}{l}\text { EDPRS Described } \\
\text { Policy Action }\end{array}$} & \multirow{2}{*}{$\begin{array}{c}\text { Key Policy Benchmarks/Outputs by } \\
\text { Year }\end{array}$} & \multirow{2}{*}{$\begin{array}{ll}\text { Traffic } & \text { light } \\
\text { scoring } & \end{array}$} \\
\hline & & & Baseline 2006 & Targets 2008 & $\begin{array}{l}\text { Traffic light } \\
\text { scoring and } \\
\text { actual } \\
\text { performance } \\
\end{array}$ & & & \\
\hline & & \multirow[t]{2}{*}{ areas) } & & & & & $\begin{array}{l}\text { Construct } 150 \text { underground drills } \\
\text { (MINITERE, Kigali City and } \\
\text { Southern Province) }\end{array}$ & $\begin{array}{l}70 \text { boreholes } \\
\text { drilled }\end{array}$ \\
\hline & & & & & & & $\begin{array}{l}\text { Initiate rain water harvesting } \\
\text { projects in } 8 \text { districts }\end{array}$ & $\begin{array}{l}53 \text { rain water } \\
\text { harvesting tanks }\end{array}$ \\
\hline & \multirow[t]{2}{*}{$\begin{array}{l}2.5 \quad \text { Improved } \\
\text { sanitation status }\end{array}$} & \multirow[t]{2}{*}{$\begin{array}{l}2.5 .1 \text { Percentage } \\
\text { of } \quad \text { population } \\
\text { using } \quad \text { hygienic } \\
\text { sanitation } \\
\text { facilities }\end{array}$} & \multirow[t]{2}{*}{$38 \%$} & \multirow[t]{2}{*}{$45 \%$} & \multirow[t]{2}{*}{$45 \%$} & \multirow[t]{2}{*}{$\begin{array}{l}\text { Develop and promote } \\
\text { sanitation facilities } \\
\text { and hygiene. }\end{array}$} & $\begin{array}{l}\text { Construct sanitation facilities in } \\
\text { pilot imidugudu, public places } \\
\text { including schools, roads, health } \\
\text { centers, markets, district } \\
\text { headquarters, in Western and } \\
\text { Southern provinces }\end{array}$ & $\begin{array}{l}\text { Fully } \\
\text { implemented }\end{array}$ \\
\hline & & & & & & & $\begin{array}{l}\text { MINITERE working with } \\
\text { MINISANTE and Districts to have } \\
\text { promoted policy, laws on water and } \\
\text { sanitation, PHAST and HAMS } \\
\text { (West and South provinces) to } \\
\text { reinforce community and schools } \\
\text { capacity in basic hygiene. }\end{array}$ & $\begin{array}{ll}\text { Policy and laws } \\
\text { have } & \text { been } \\
\text { developed } & \end{array}$ \\
\hline & \multirow[t]{2}{*}{$\begin{array}{l}2.6 \quad \text { Integrated } \\
\text { and sustainable } \\
\text { management of } \\
\text { water resources }\end{array}$} & \multirow[t]{2}{*}{$\begin{array}{l}2.6 .1 \text { Percentage } \\
\text { of water resources } \\
\text { complying with } \\
\text { water quality } \\
\text { standard }\end{array}$} & \multirow[t]{2}{*}{$25 \%$} & \multirow[t]{2}{*}{$30 \%$} & \multirow[t]{2}{*}{$30 \%$} & $\begin{array}{l}\text { Operationalize the } \\
\text { water information } \\
\text { system and protect } \\
\text { river basins }\end{array}$ & $\begin{array}{l}\text { Put in place an Institutional and } \\
\text { Legal framework on IWRMUpdate } \\
\text { the WIS and rehabilitate 5 } \\
\text { hydrological and limn metric } \\
\text { stations }\end{array}$ & $\begin{array}{l}\text { Fully } \\
\text { implemented }\end{array}$ \\
\hline & & & & & & & $\begin{array}{l}\text { Conduct Water resource assessment } \\
\text { to facilitate investment for } \\
\text { economic production }\end{array}$ & $\begin{array}{l}\text { Feasibility study } \\
\text { completed }\end{array}$ \\
\hline & & & & & 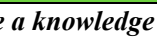 & sed society & & \\
\hline
\end{tabular}




\begin{tabular}{|c|c|c|c|c|c|c|c|c|}
\hline $\begin{array}{l}\text { EDPRS } \\
\text { STRATEGIC } \\
\text { OBJECTIVES }\end{array}$ & $\begin{array}{l}\text { EDPRS } \\
\text { STRATEGIC } \\
\text { OUTCOMES } \\
\text { (Results) }\end{array}$ & \multirow[t]{2}{*}{ INDICATORS } & \multicolumn{3}{|c|}{ EXPECTED PERFORMANCE } & \multicolumn{3}{|c|}{ PUBLIC POLICY ACTIONS } \\
\hline & & & & & & Policy Action & Year & $\begin{array}{l}\text { Iraffic } \\
\text { scoring }\end{array}$ \\
\hline & & & Baseline 2006 & Targets 2008 & $\begin{array}{l}\text { Traffic light } \\
\text { scoring and } \\
\text { actual } \\
\text { performance }\end{array}$ & & 2008 & \\
\hline & $\begin{array}{l}2.7 \\
\text { population skills }\end{array}$ & $\begin{array}{l}2.7 .1 \text { (i) Primary } \\
\text { school completion } \\
\text { rate } \\
\text { (ii) Male/female } \\
\text { ratio in primary } \\
\text { school completion }\end{array}$ & $52 \%$ & $55 \%$ & $53 \%$ & $\begin{array}{l}\text { Ensure classroom } \\
\text { construction, } \\
\text { qualification and } \\
\text { motivation of } \\
\text { teachers and provide } \\
\text { textbooks with pupil } \\
\text { textbook ratio of } 1: 1 \\
\text { in core subjects to } \\
\text { ensure completion } \\
\text { rate }\end{array}$ & $\begin{array}{l}\text { Develop EMIS Phase I and M\&E } \\
\text { phase }\end{array}$ & $\begin{array}{l}\text { Fully } \\
\text { implemented }\end{array}$ \\
\hline & & $\begin{array}{lr}2.7 .2 & \text { Primary } \\
\text { school pupil to } \\
\text { qualified teacher } \\
\text { ratio }\end{array}$ & $72.7: 1$ & $72: 1$ & $66: 1$ & $\begin{array}{l}\text { Provide sufficient } \\
\text { contract teachers who } \\
\text { upon satisfactory } \\
\text { work join normal } \\
\text { permanent cadres }\end{array}$ & $\begin{array}{l}\begin{array}{l}\text { Publish teacher development and } \\
\text { management }\end{array} \\
\text { policy } \\
\text { Recruit } 1000 \text { teachers }\end{array}$ & $\begin{array}{l}\text { Fully } \\
\text { implemented }\end{array}$ \\
\hline & & $\begin{array}{l}2.7 .3 \text { Transition } \\
\text { from basic } \\
\text { education (TC) to } \\
\text { upper secondary } \\
\text { education }\end{array}$ & $82 \%$ & $84 \%$ & $78,6 \%$ & $\begin{array}{l}\text { Implement post basic } \\
\text { education which } \\
\text { addresses any } \\
\text { possible mismatch } \\
\text { between } \\
\text { education and post } \\
\text { basic education as } \\
\text { well as between post } \\
\text { basic and higher } \\
\text { education }\end{array}$ & $\begin{array}{l}\text { Develop post basic education } \\
\text { strategy and ensure ICT in } \\
\text { education policy approved }\end{array}$ & $\begin{array}{l}\text { Fully } \\
\text { implemented }\end{array}$ \\
\hline & & $\begin{array}{l}2.7 .4 \text { Ratio of } \\
\text { higher education } \\
\text { students enrolled } \\
\text { in science courses } \\
\text { for girls }\end{array}$ & $30 \%$ & $32 \%$ & $30 \%$ & $\begin{array}{lr}\text { Ensure } & \text { Girls' } \\
\text { Education } & \text { Policy } \\
\text { Strategy } & \text { indicates } \\
\text { affirmative } & \text { action } \\
\text { towards } & \text { Girls' } \\
\text { participation } & \text { and } \\
\text { performance in HLIs }\end{array}$ & $\begin{array}{l}\text { Publish Girls' Education Policy and } \\
\text { ensure approval of SEN policy }\end{array}$ & $\begin{array}{l}\text { Fully } \\
\text { implemented }\end{array}$ \\
\hline
\end{tabular}




\begin{tabular}{|c|c|c|c|c|c|c|c|c|}
\hline \multirow{2}{*}{$\begin{array}{l}\text { EDPRS } \\
\text { STRATEGIC } \\
\text { OBJECTIVES }\end{array}$} & \multirow{2}{*}{$\begin{array}{l}\text { EDPRS } \\
\text { STRATEGIC } \\
\text { OUTCOMES } \\
\text { (Results) }\end{array}$} & \multirow[t]{2}{*}{ INDICATORS } & \multirow{2}{*}{\multicolumn{3}{|c|}{ EXPECTED PERFORMANCE }} & \multirow{2}{*}{\multicolumn{3}{|c|}{ PUBLIC POLICY ACTIONS }} \\
\hline & & & & & & & & \\
\hline & & & & & & \multirow[t]{2}{*}{$\begin{array}{l}\text { EDPRS Described } \\
\text { Policy Action }\end{array}$} & \multirow[t]{2}{*}{$\begin{array}{l}\text { Key Policy Benchmarks/Outputs by } \\
\text { Year }\end{array}$} & \multirow[t]{2}{*}{$\begin{array}{ll}\text { Traffic light } \\
\text { scoring }\end{array}$} \\
\hline & & & Baseline 2006 & Targets 2008 & $\begin{array}{l}\text { Traffic light } \\
\text { scoring and } \\
\text { actual } \\
\text { performance }\end{array}$ & & & \\
\hline & & $\begin{array}{l}2.7 .5 \text { Proportion } \\
\text { of employers who } \\
\text { are satisfied with } \\
\text { the performance } \\
\text { of } \\
\text { graduates TVET }\end{array}$ & $8 \% *$ & $8.5 \%$ & $\begin{array}{c}\mathrm{N} / \mathrm{A} \\
\text { (baselines and } \\
\text { targets yet to } \\
\text { be set) }\end{array}$ & $\begin{array}{l}\text { Ensure TVET } \\
\text { strategic policy and } \\
\text { plan to indicate which } \\
\text { new courses/schools } \\
\text { to be established and } \\
\text { which courses to be } \\
\text { improved/expanded } \\
\text { to accommodate more } \\
\text { students in response } \\
\text { to market demand } \\
\text { conduct employers' } \\
\text { survey }\end{array}$ & Publish TVET policy & $\begin{array}{l}\text { Fully } \\
\text { implemented }\end{array}$ \\
\hline & \multicolumn{8}{|c|}{ Combat poverty and extreme poverty } \\
\hline & \multirow[t]{2}{*}{$\begin{array}{lr}2.8 & \text { Improved } \\
\text { Social Safety Net }\end{array}$} & $\begin{array}{l}2.8 .1 \text { (i) The } \\
\text { percentage of } \\
\text { households in the } \\
\text { bottom two } \\
\text { categories of } \\
\text { extreme poverty } \\
\text { according to } \\
\text { UBUDEHE } \\
\text { classification (ii) } \\
\text { The poverty-gap } \\
\text { index }\end{array}$ & $\begin{array}{c}\text { No baseline } \\
\text { survey to be } \\
\text { conducted in } \\
2009\end{array}$ & NA & $\begin{array}{l}\text { Target to be } \\
\text { set (N/A) }\end{array}$ & $\begin{array}{l}\text { Government to begin } \\
\text { to implement and } \\
\text { operationalize the } \\
\text { VUP Policy } \\
\text { Framework in the } 30 \\
\text { pilot districts }\end{array}$ & $\begin{array}{l}\text { Government has committed budget } \\
\text { allocations to implement the VUP } \\
\text { program in at least } 6 \text { pilot sectors } \\
\text { and established a core management } \\
\text { team to implement the VUP policy } \\
\text { framework. }\end{array}$ & $\begin{array}{l}\text { Fully } \\
\text { implemented }\end{array}$ \\
\hline & & $\begin{array}{lr}2.8 .2, & \% \\
\text { households } & \text { of } \\
\text { eligible } & \text { for } \\
\text { support, } & \% \\
\text { granted } & \text { public } \\
\text { works } & \end{array}$ & 0 & $35 \%$ & $35 \%$ & $\begin{array}{lr}\text { Establish } & \text { and } \\
\text { implement a } & \text { Public } \\
\text { Works } & \text { policy } \\
\text { framework } & \\
\text { (incorporating } & \text { good } \\
\text { international practice) } \\
\text { underpinned r by } \\
\text { training at local } \\
\text { government level. }\end{array}$ & $\begin{array}{l}\text { Finalize budget allocations for VUP } \\
\text { public works in line with EDPRS } \\
\text { priorities and complete the } \\
\text { implementation manuals of PW } \\
\text { programmes incorporating } \\
\text { international good practice. }\end{array}$ & $\begin{array}{l}\text { Fully } \\
\text { implemented }\end{array}$ \\
\hline
\end{tabular}




\begin{tabular}{|c|c|c|c|c|c|c|c|c|}
\hline \multirow{2}{*}{$\begin{array}{l}\text { EDPRS } \\
\text { STRATEGIC } \\
\text { OBJECTIVES }\end{array}$} & $\begin{array}{l}\text { EDPRS } \\
\text { STRATEGIC } \\
\text { OUTCOMES } \\
\text { (Results) }\end{array}$ & \multirow[t]{2}{*}{ INDICATORS } & \multicolumn{3}{|c|}{ EXPECTED PERFORMANCE } & \multicolumn{3}{|c|}{ PUBLIC POLICY ACTIONS } \\
\hline & & & & & & \multirow[t]{2}{*}{$\begin{array}{l}\text { EDPRS Described } \\
\text { Policy Action }\end{array}$} & \multirow[t]{2}{*}{$\begin{array}{c}\text { Key Policy Benchmarks/Outputs by } \\
\text { Year }\end{array}$} & \multirow[t]{2}{*}{$\begin{array}{ll}\text { Traffic light } \\
\text { scoring }\end{array}$} \\
\hline & & & Baseline 2006 & Targets 2008 & $\begin{array}{l}\text { Traffic light } \\
\text { scoring and } \\
\text { actual } \\
\text { performance } \\
\end{array}$ & & & \\
\hline & & 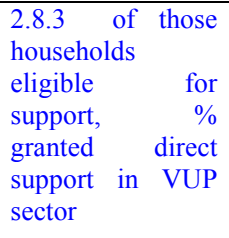 & 0 & N/A & $\mathrm{N} / \mathrm{A}$ & $\begin{array}{l}\text { Incorporate direct } \\
\text { support activities into } \\
\text { all district and } \\
\text { imirenge plans, and in } \\
\text { JADFs at District and } \\
\text { Umurenge level }\end{array}$ & $\begin{array}{l}\text { Finalize budget allocations for VUP } \\
\text { direct support packages in line with } \\
\text { EDPRS priorities and complete the } \\
\text { implementation manuals of DS } \\
\text { programmes incorporating } \\
\text { international good practice. }\end{array}$ & $\begin{array}{l}\text { Fully } \\
\text { implemented }\end{array}$ \\
\hline & & $\begin{array}{l}2.8 .4 \text { Number of } \\
\text { vulnerable } \\
\text { households } \\
\text { accessing credit } \\
\text { and savings } \\
\text { facilities }\end{array}$ & 0 & 6390 & 17626 & $\begin{array}{lr}\text { Implement } & \text { and } \\
\text { Operationalize } & \text { the } \\
\text { VUP policy } & \end{array}$ & & \\
\hline & $\begin{array}{ll}2.9 & \text { Integrated } \\
\text { social } & \text { protection } \\
\text { programming }\end{array}$ & $\begin{array}{l}2.9 .1 \text { Average } \\
\text { social protection } \\
\text { income provided } \\
\text { to poor and } \\
\text { vulnerable groups } \\
\text { through district } \\
\text { social assistance } \\
\text { budget }\end{array}$ & & NA & N/A & $\begin{array}{l}\text { Put in place social } \\
\text { protection strategy } \\
\text { and undertake } \\
\text { comprehensive } \\
\text { mapping of social } \\
\text { protection sector }\end{array}$ & $\begin{array}{l}\text { Undertake comprehensive mapping } \\
\text { of social protection sector by } \\
\text { MINALOC and inform social } \\
\text { protection strategy development. } \\
\text { Endorse minimum package of } \\
\text { services for OVCs. }\end{array}$ & $\begin{array}{l}\text { Fully } \\
\text { implemented }\end{array}$ \\
\hline & & & & & & $\begin{array}{l}\text { Define and adopt } \\
\text { change management } \\
\text { methodology for } \\
\text { VUP implementation }\end{array}$ & $\begin{array}{l}\text { Define and adopt change } \\
\text { management methodology in all } \\
\text { districts for pilot VUP sectors } \\
\text { (MINALOC) } \\
\begin{array}{l}\text { Develop Itorero scheme } \\
\text { (community leaders to act as } \\
\text { change agents) to operate in all } \\
\text { imirenge }\end{array}\end{array}$ & $\begin{array}{l}\text { Fully } \\
\text { implemented }\end{array}$ \\
\hline
\end{tabular}




\begin{tabular}{|c|c|c|c|c|c|c|c|c|}
\hline \multirow{2}{*}{$\begin{array}{l}\text { EDPRS } \\
\text { STRATEGIC } \\
\text { OBJECTIVES }\end{array}$} & \multirow{2}{*}{$\begin{array}{l}\text { EDPRS } \\
\text { STRATEGIC } \\
\text { OUTCOMES } \\
\text { (Results) }\end{array}$} & \multirow[t]{2}{*}{ INDICATORS } & \multicolumn{3}{|c|}{ EXPECTED PERFORMANCE } & \multicolumn{3}{|c|}{ PUBLIC POLICY ACTIONS } \\
\hline & & & & & & \multirow[t]{2}{*}{$\begin{array}{l}\text { EDPRS Described } \\
\text { Policy Action }\end{array}$} & \multirow[t]{2}{*}{$\begin{array}{c}\text { Key Policy Benchmarks/Outputs by } \\
\text { Year }\end{array}$} & \multirow[t]{2}{*}{$\begin{array}{ll}\text { Traffic } & \text { light } \\
\text { scoring } & \end{array}$} \\
\hline & & & Baseline 2006 & Targets 2008 & $\begin{array}{l}\text { Traffic light } \\
\text { scoring and } \\
\text { actual } \\
\text { performance } \\
\end{array}$ & & & \\
\hline \multirow[t]{6}{*}{$\begin{array}{l}3 \text { Enhanced } \\
\text { gains } \text { through } \\
\text { good } \\
\text { governance }\end{array}$} & $\begin{array}{l}\text { 3.1 Enhanced } \\
\text { partnership } \\
\text { between GoR, } \\
\text { Civil Society and } \\
\text { Private Sector. }\end{array}$ & $\begin{array}{l}3.1 .1 \text { Percentage } \\
\text { of CSO and PS } \\
\text { representation in } \\
\text { JADF and } \\
\text { Decentralization } \\
\text { Cluster }\end{array}$ & $70 \%$ & $75 \%$ & N/A & $\begin{array}{l}\text { Public, Private sector } \\
\text { and Civil Society } \\
\text { fully engaged in } \\
\text { successful } \\
\text { partnerships for } \\
\text { effective delivery of } \\
\text { good governance and } \\
\text { decentralization }\end{array}$ & $\begin{array}{l}\text { Level of representation of private } \\
\text { and civil actors in national and local } \\
\text { decision-making bodies improved }\end{array}$ & $\begin{array}{l}\text { Fully } \\
\text { implemented }\end{array}$ \\
\hline & \multirow[t]{5}{*}{$\begin{array}{l}.2 \text { Effective } \\
\text { coordination of } \\
\text { national labour } \\
\text { force }\end{array}$} & \multirow[t]{5}{*}{$\begin{array}{l}3.2 .1 \text { Number of } \\
\text { new non-farm } \\
\text { jobs created } \\
\text { (cumulative } \\
\text { target) } \\
\text { (indicative)3 }\end{array}$} & \multirow[t]{5}{*}{$N A$} & \multirow[t]{5}{*}{$N A$} & \multirow[t]{5}{*}{$N A$} & \multirow[t]{4}{*}{$\begin{array}{l}\text { National employment } \\
\text { policy and strategy } \\
\text { disseminated and } \\
\text { implemented }\end{array}$} & $\begin{array}{l}\text { Implement program to take at least } \\
300 \text { youth from universities on } \\
\text { internship; at least } 300 \text { youth and } \\
500 \text { women in entrepreneurship; }\end{array}$ & $\begin{array}{l}\text { Multi sector } \\
\text { capacity } \\
\text { building } \\
\text { program } \\
\text { supported } 20 \\
\text { youth to attend } \\
\text { the Internship } \\
\text { program }\end{array}$ \\
\hline & & & & & & & $\begin{array}{l}\text { At least } 300 \text { youth trained in } \\
\text { entrepreneurship }\end{array}$ & 300 youth trained \\
\hline & & & & & & & $\begin{array}{l}\text { At least } 500 \text { women trained in } \\
\text { entrepreneurship; }\end{array}$ & $\begin{array}{ll}900 & \text { women } \\
\text { trained } & \end{array}$ \\
\hline & & & & & & & $\begin{array}{l}\text { Collaborate with CAPMER, RIAM } \\
\text { and Women Council to establish } \\
\text { RWODA }\end{array}$ & $\begin{array}{l}\text { Fully } \\
\text { implemented }\end{array}$ \\
\hline & & & & & & $\begin{array}{l}\text { Strengthen } \\
\text { savings \& } \begin{array}{r}\text { Youth } \\
\text { credit }\end{array} \\
\text { institutions and } \\
\text { enhance employment } \\
\text { of youths through } \\
\text { cooperatives } \\
\text { (MIJESPOC, } \\
\text { MINICOM, NYC \& } \\
\text { BNR) }\end{array}$ & $\begin{array}{llll}\text { Strengthen } & \text { district wide } & 5 \text { Youth } \\
\text { savings \& } & \text { credit } & \text { schemes } \\
& & & \\
\text { Prepare } 50 & \text { diversified } & \text { youth } \\
\text { cooperatives } & & & \end{array}$ & $\begin{array}{l}\text { Fully } \\
\text { implemented }\end{array}$ \\
\hline
\end{tabular}




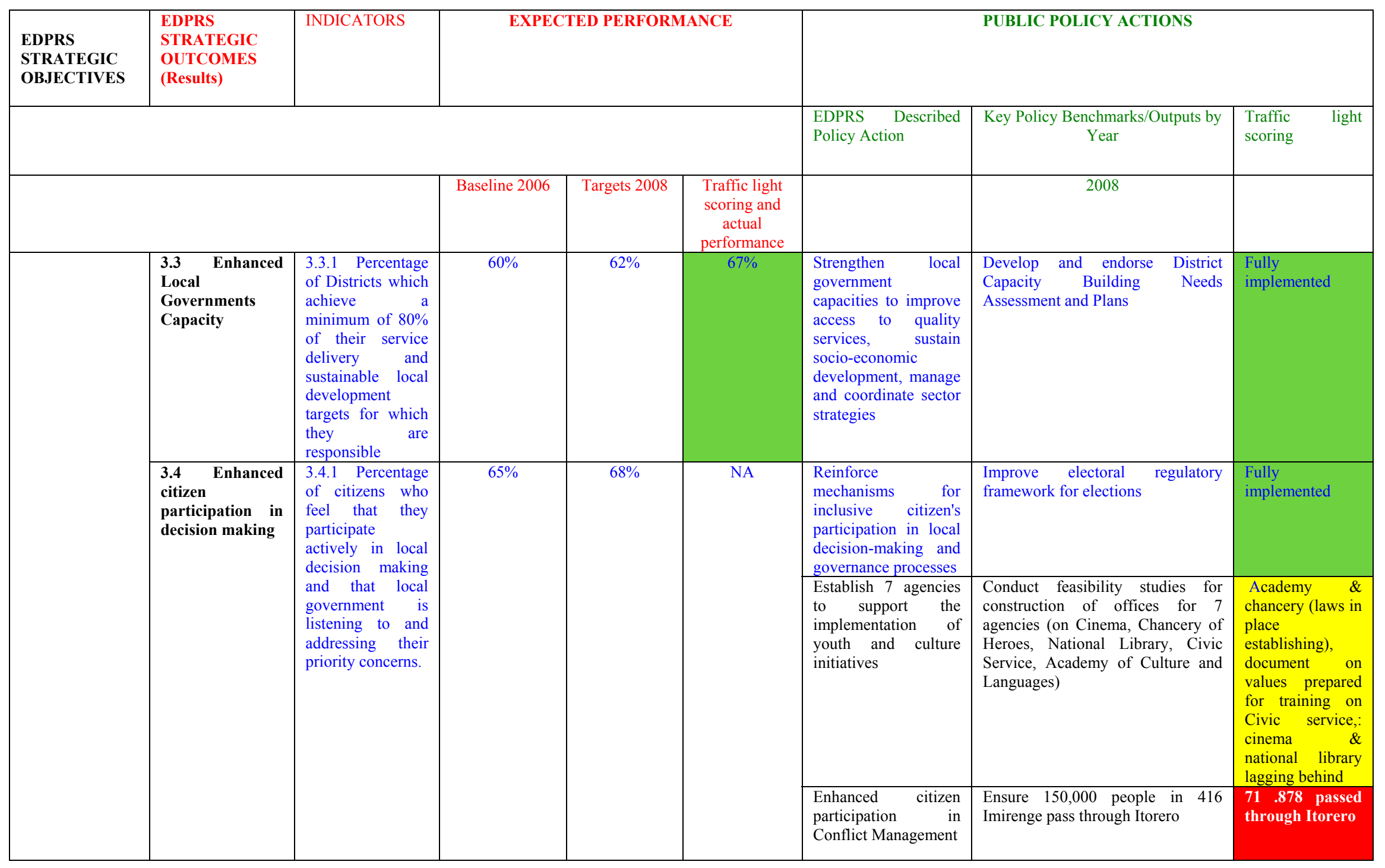




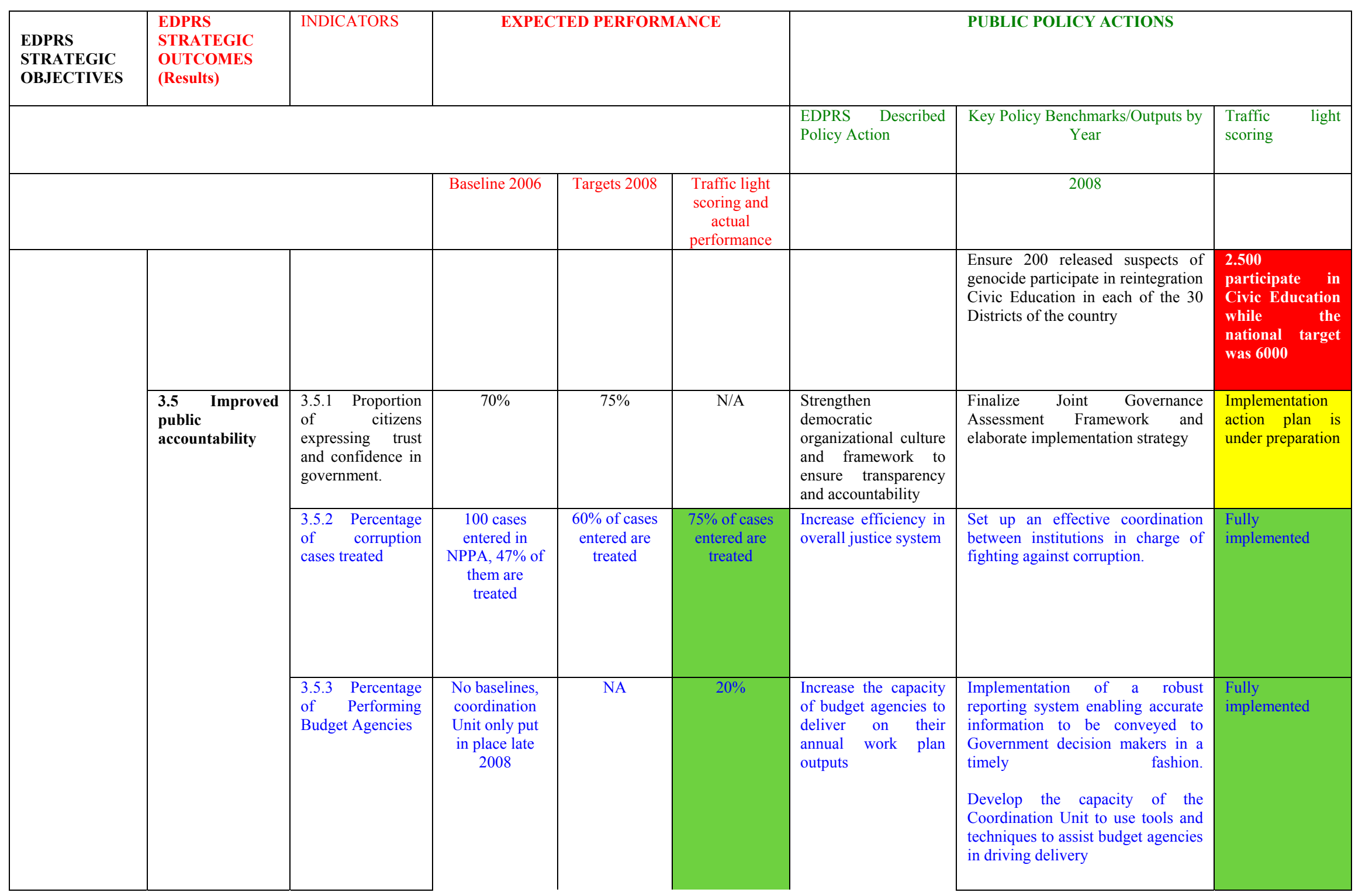




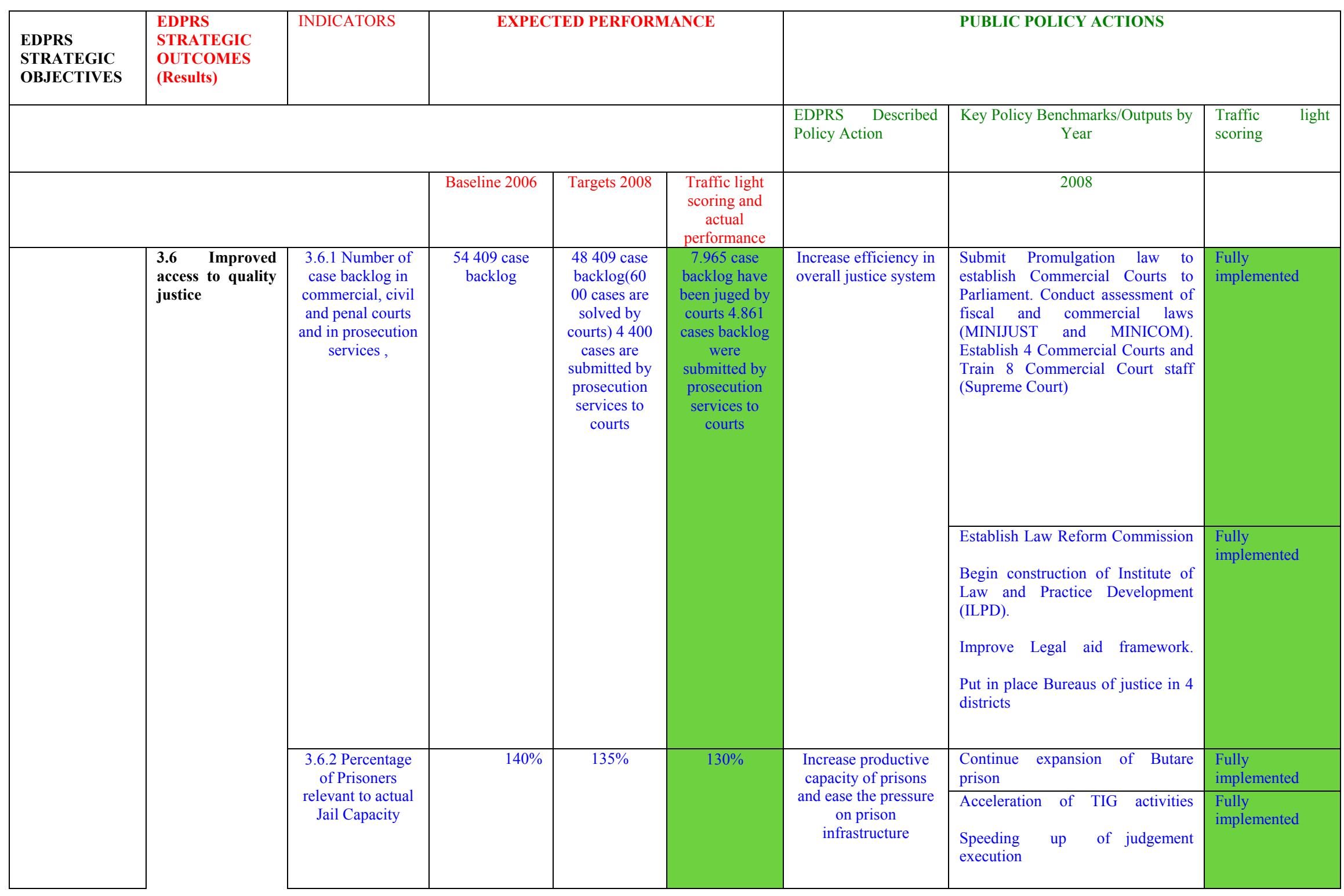




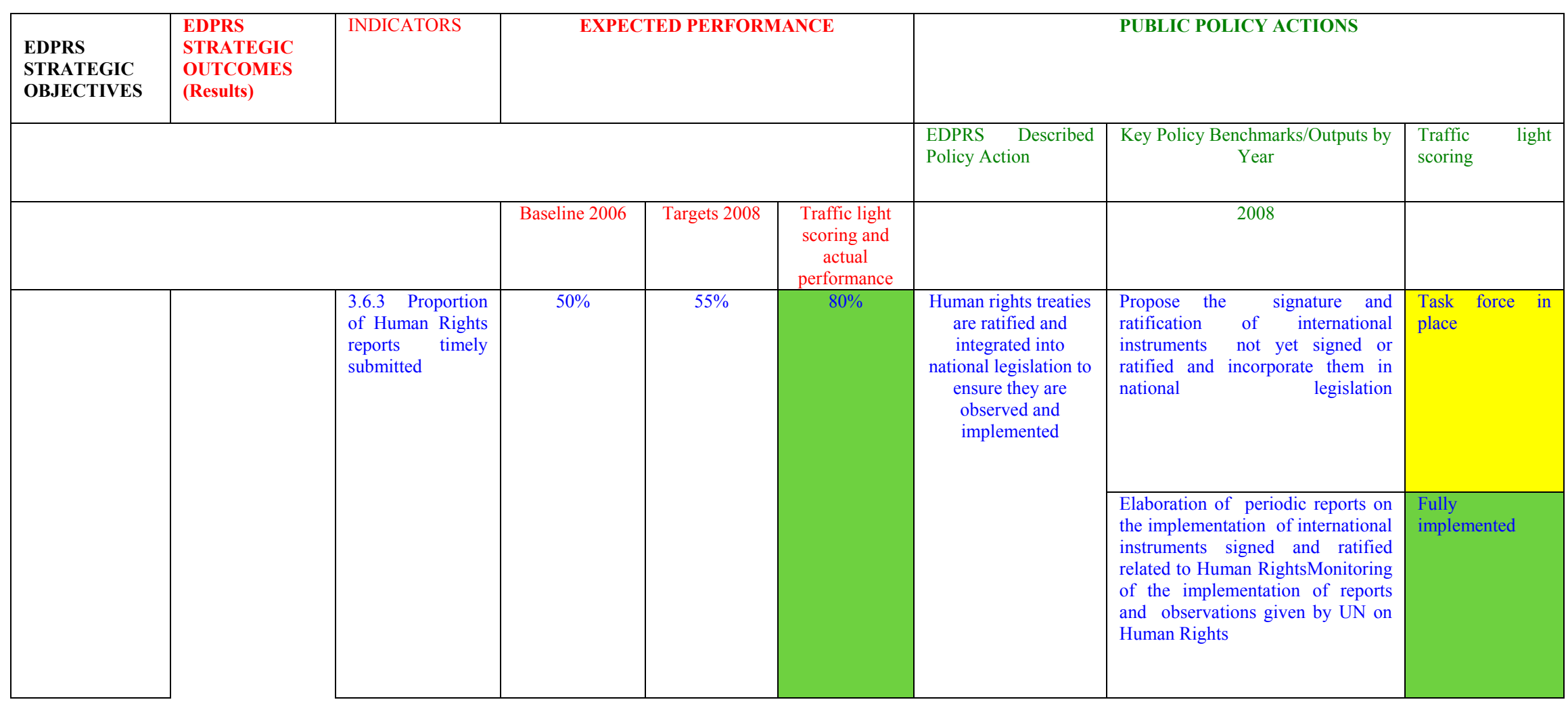




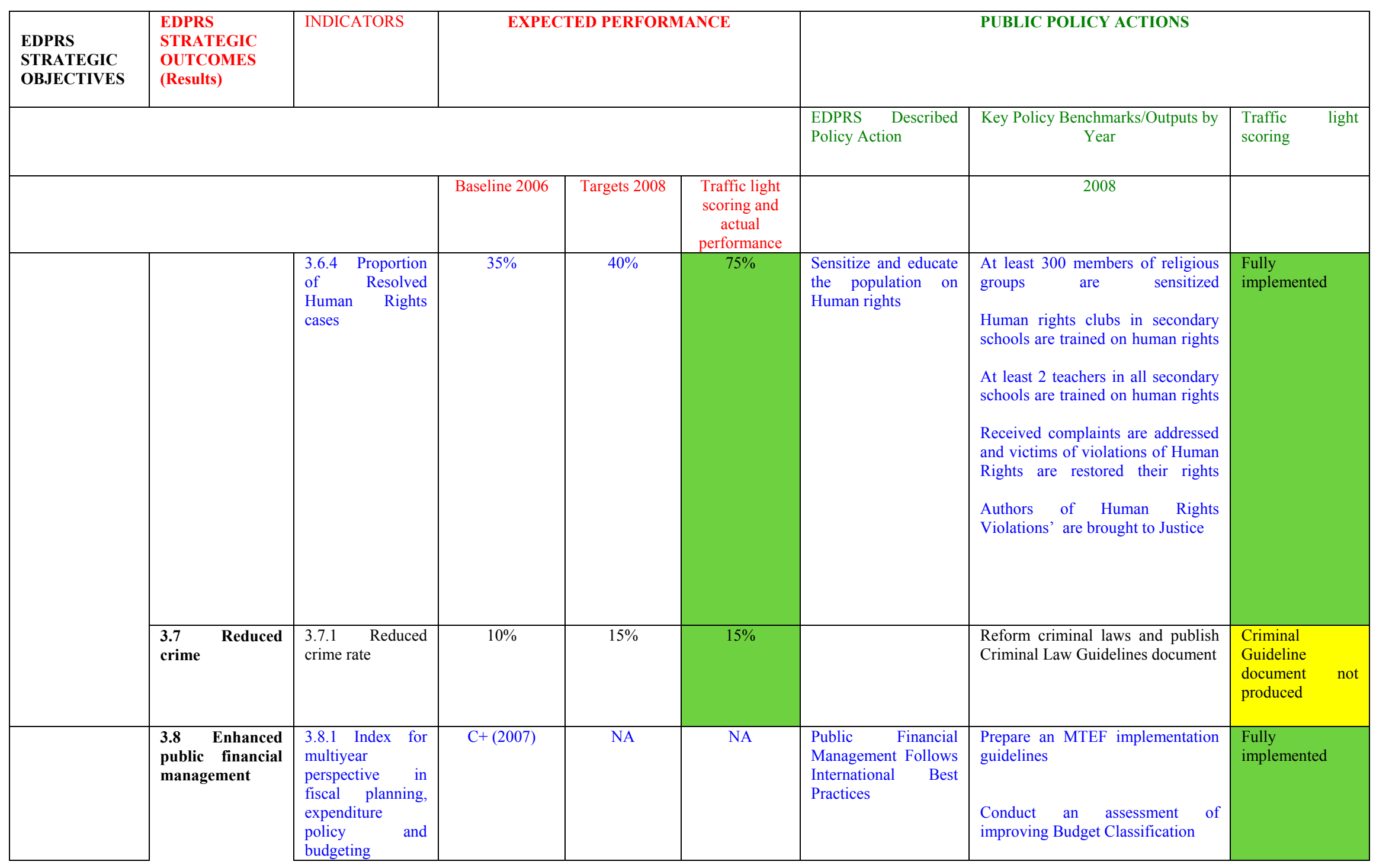




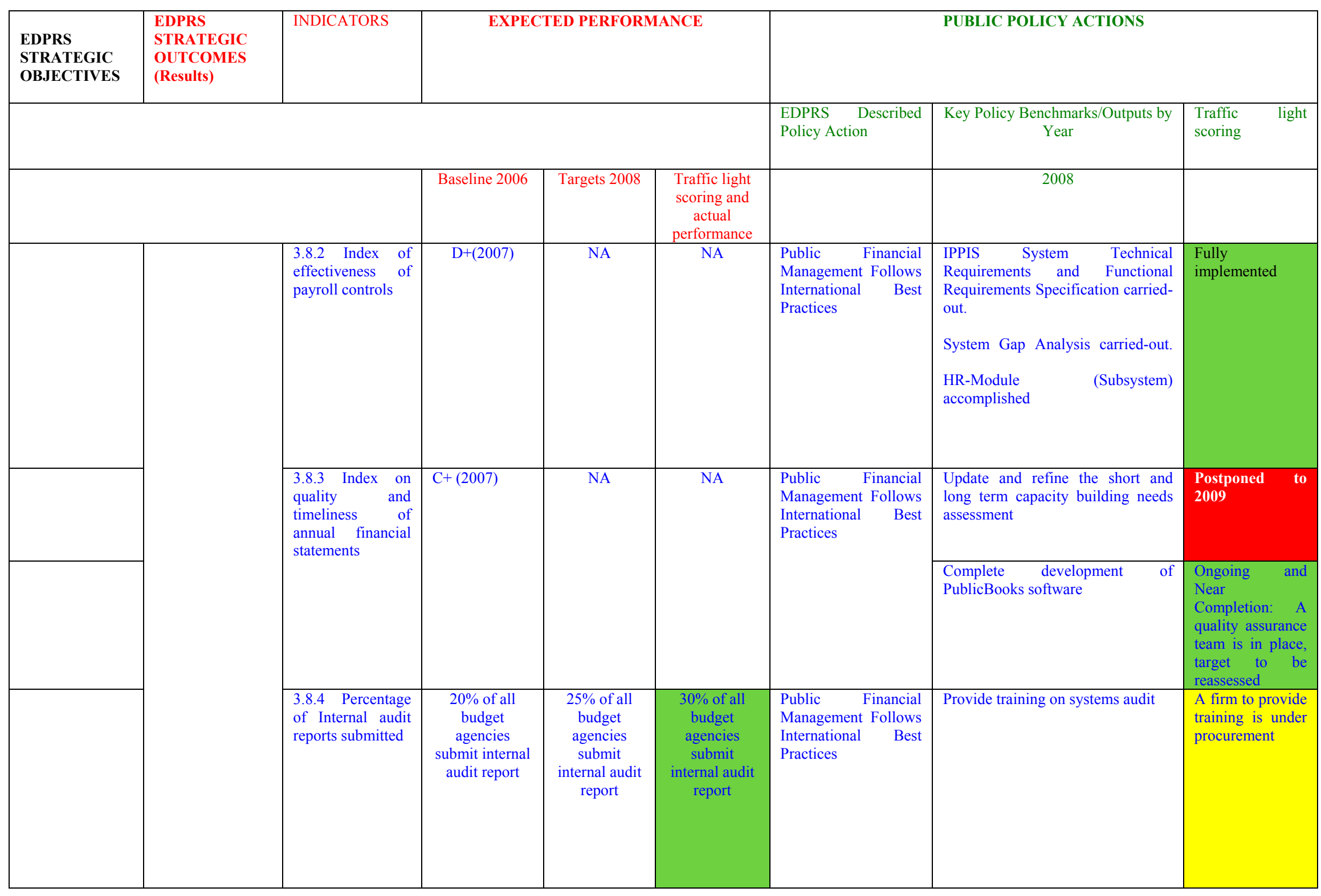




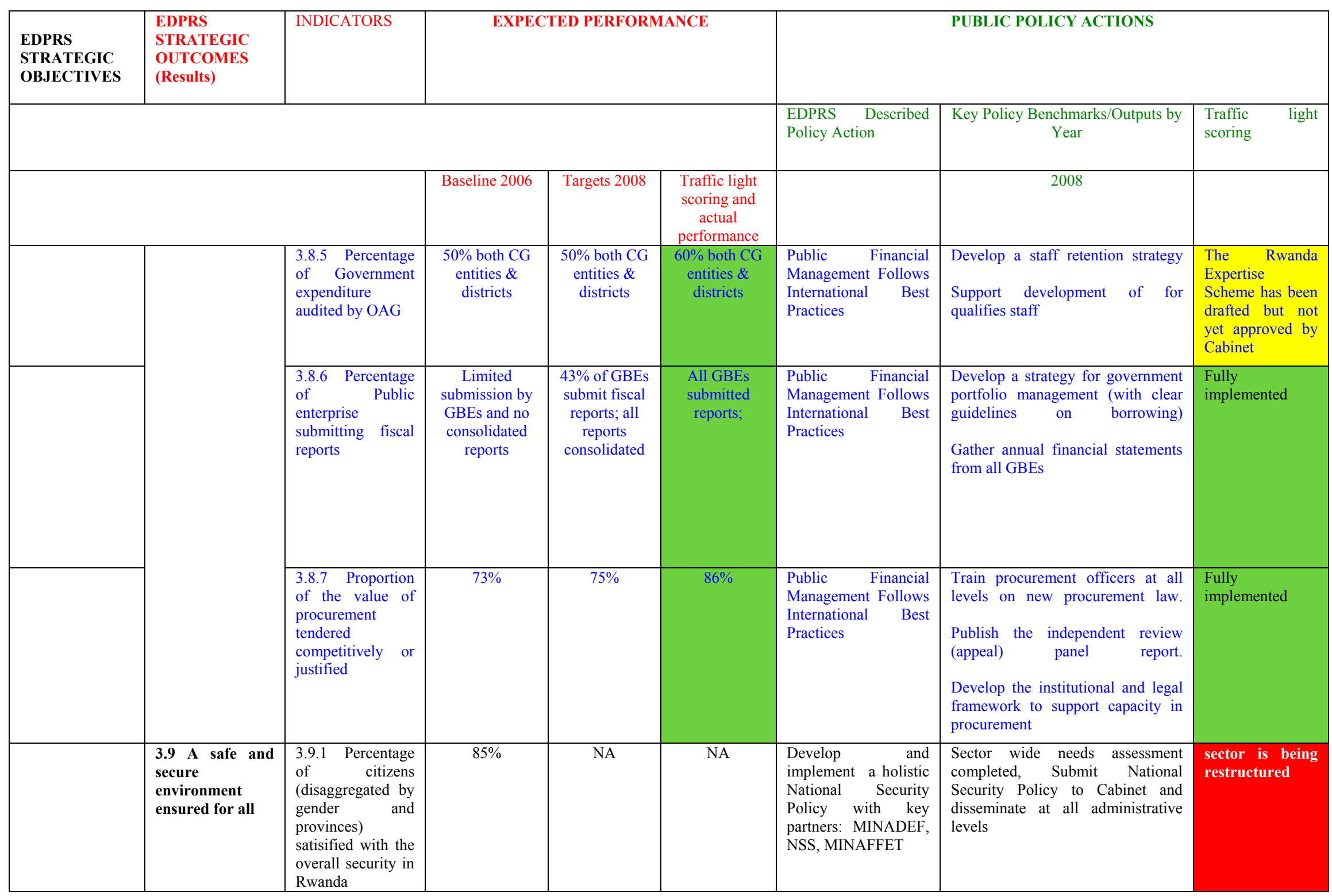




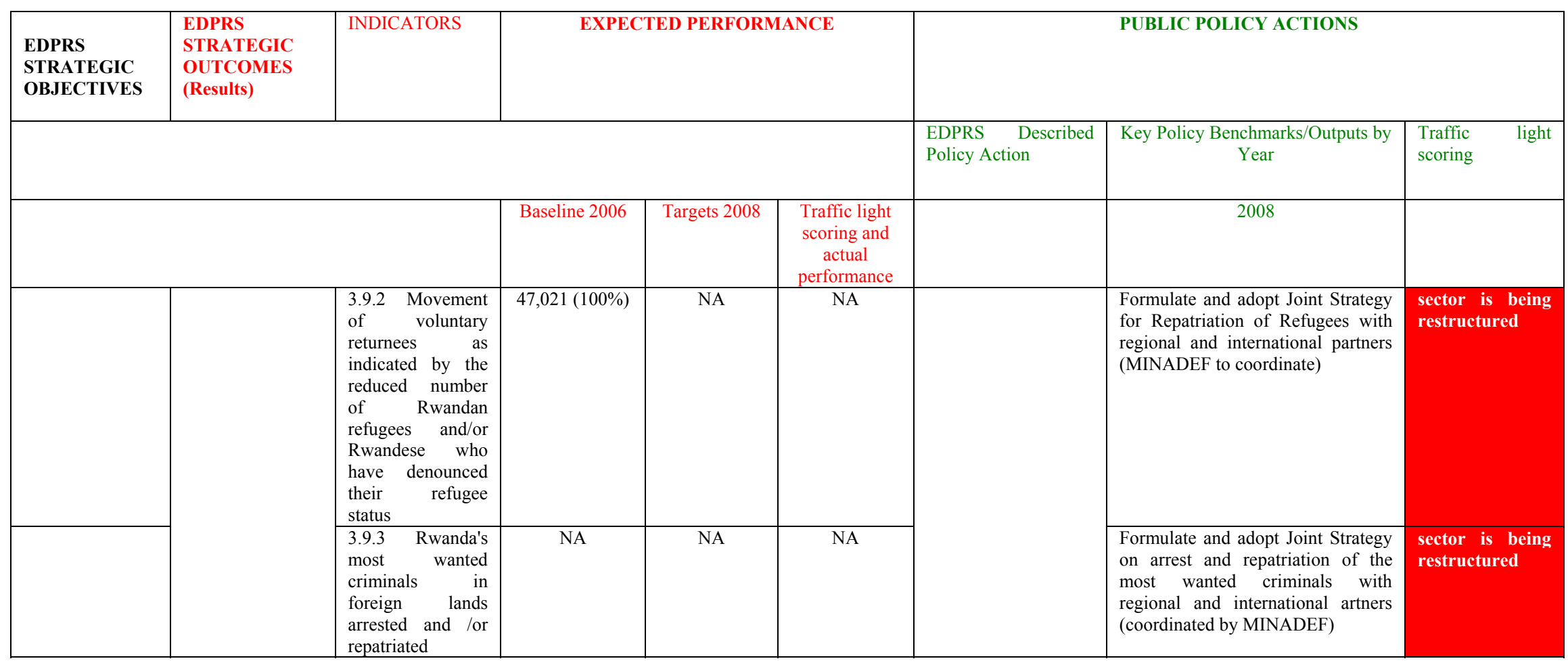




\section{REPUBLIC OF RWANDA}

MINISTRY OF FINANCE AND ECONOMIC PLANNING

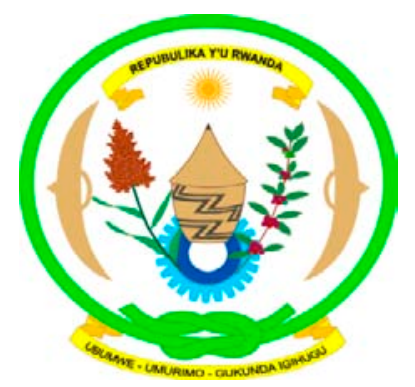

\section{ECONOMIC DEVELOPMENT AND POVERTY REDUCTION STRATEGY (EDPRS) IMPLEMENTATION REPORT JANUARY-JUNE 2009}

OCTOBER 2009 


\section{Table of Contents}

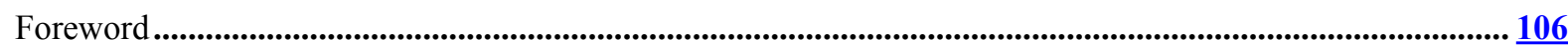

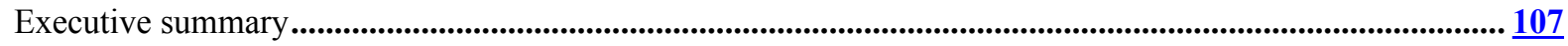

Introduction ..............................................................................................................................................................

Economic Cluster.........................................................................................................................................................

Macro and Financial Sector ................................................................................................................................ 112

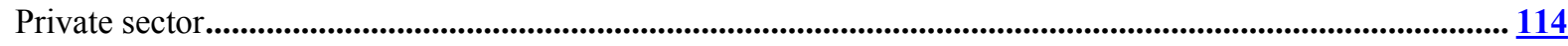

Infrastructure sector ........................................................................................................................................................

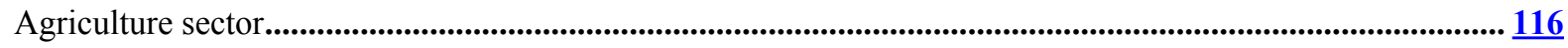

Environment and natural resources Sector...........................................................................................................116

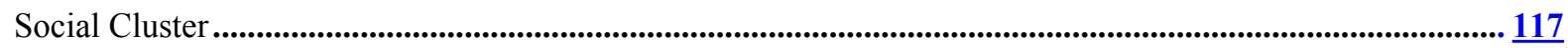

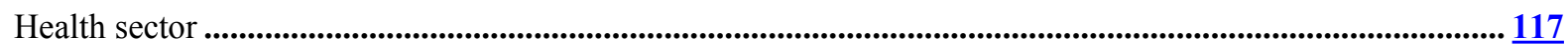

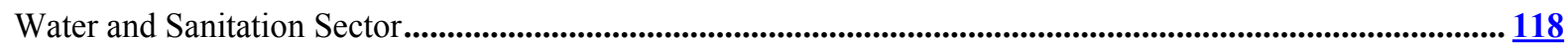

Education sector......................................................................................................................................................... 119

Social Protection Sector ............................................................................................................................................ 120

Youth Sector .............................................................................................................................................................. 121

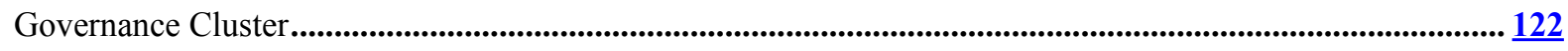

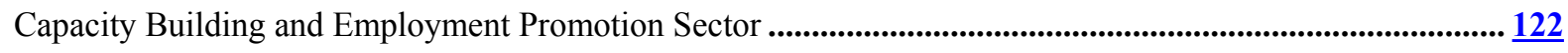

Decentralization, Citizen Participation, Empowerment, Transparency and Accountability (DCPETA) Sector $\underline{122}$

Justice, Reconciliation, Law and Order sector ......................................................................................................... 123

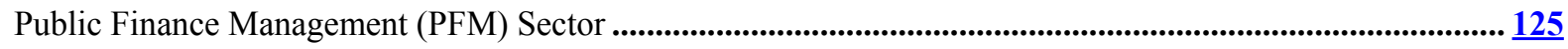

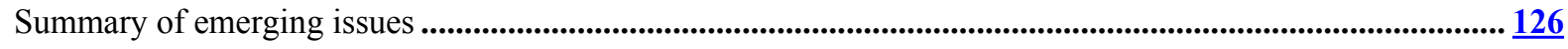

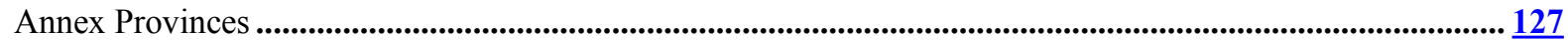

Annex: Detailed EDPRS Result and Policy Matrix (RPM) mid -term report ...................................................... 136 


\section{FOREWORD}

One and a half years down the road of the implementation of the Economic Development and Poverty Reduction Strategy (EDPRS), we are once again at the point of self assessment, where we analyze the extent to which we have achieved the objectives and targets we set for ourselves.

From the EDPRS' inception till now, it is clear that progress is being made. During the very first year of implementation, we had a notable performance with $81 \%$ of the quantitative targets timely met, whilst $80 \%$ of the policy targets were achieved.

This year 2009, the report mainly focuses only on the policy actions that were selected for the transitional budget period of January to June 2009, where $79 \%$ of the targets were on track, and $19 \%$ were in good progress.

I would like to applaud the efforts of all stakeholders while also reminding each one that we have the potential to do better. We need no reminder however, of the ambitious spirit that characterizes this Country, a spirit that has to be carried throughout EDPRS and all our development agenda. Bearing this in mind, our work should be directed towards more efficiency and sense of urgency to ensure higher success rates in the future and better service delivery. 


\section{Executive summary}

This paper outlines the progress made during the Mini Budget Period in the implementation of the Economic Development and Poverty Reduction Strategy (EDPRS). It is based on the selected policy actions as defined in the EDPRS results and policy matrix for January to June, 2009. A wider range of indicators, targets and policy actions are monitored by every line Ministry through the existing sector monitoring and evaluation systems.

The EDPRS results and policy matrix is organised around the 3 EDPRS flagship programs which have been aligned to the three clusters (Economic, Social and Governance that were established by the Rubavu retreat.

Within each strategic objective, there are a number of strategic outcomes, indicators and associated targets and policy actions. Each sector contributes to the achievement of one or more strategic outcomes, through the implementation of agreed policy actions.

Because the data collection of most of the quantitative performance indicators is annual, this report is only based on the progress made in the implementation of the policy actions planned for January to June 2009.

In overall, a total of 107 policy actions were planned for the mini-budget period. Out of these, a total of 84 policy actions (79\%) were completed, 21 policy actions (19\%) were partially achieved and only 2 policy actions (2\%) were lagging significantly behind or had not commenced by the end of June 2009.

The two policy actions that were not commenced are the establishment of the Axle Load control system for $50 \%$ of the National Paved Road Network and the signing of Multi Annual (3 years) Output and Performance Based Road Contracts (OPBRC's) by Districts in the Transport Sector.

The following are some of the key achievements by cluster:

\section{Economic cluster}

This cluster covers the Macro Economic and Financial sector and the economic sectors of Agriculture, Infrastructure (Energy, Transport), Private Sector development as well as Environment and Natural Resources management.

As regards the cluster, the inflation rate has declined overall from $22.3 \%$ in December 2008 to $10.1 \%$ in June 2009 and the trend was towards the EDPRS objective of a single digit inflation rate. There has been also relative price stability with the overall change in the price index of $1.8 \%$ at end June2009, compared to December 2008. Furthermore, the Rwandan Franc exchange rate has been stable during the first half of 2009 with a moderate depreciation of $2.3 \%$ from December 2008 to June 2009. 
The Microfinance credit fund has been made operational and a National Payment Strategy was developed. The Law on Security Interests in Immovable Property and mortgages has also been passed in Parliament.

Efforts to continue to improve the 'Doing Business' environment are gaining momentum with 8 licences identified for action, in addition to those already streamlined at the beginning of 2009 . All borders have also been connected to the ASYCUDA network (customs software) except Rutete which is to be connected in the 2009/10 fiscal year.

A 20 MW Jabana plant of heavy fuel was made operational and a Draft Law establishing the Rwanda Energy and Water Development Boards has been submitted to Parliament. The Ministry of Infrastructure (MININFRA) has also signed a contract with an Independent Power Producer (Contour Global) for the generation of $100 \mathrm{MW}$ of electricity from the Methane.

The target for periodic maintenance of $20 \mathrm{~km}$ of paved road has been met and $90 \%$ of the rehabilitation and maintenance works of the $120 \mathrm{~km}$ earth roads have been completed. The Rwanda Transport Agency was also adopted by Cabinet, while the Road Act is in final stages of preparation.

Preliminary estimates suggest that growth in agricultural production was $11.2 \%$ in volume during the seasons A and B of 2009, which also indicates the Sector withstanding the impact of the economic slowdown.

The seed policy with its five year costed action plan have been adopted by Cabinet and an evaluation study of the implementation of the 'One Cow per Household' has also been completed.

By mid-June 2009, 67\% of the total demarcated parcels for land registration had been issued land certificates and $70 \%$ of the digital orthophotos (hard and soft copies) have been completed. Twenty five (25) District Forest Management Plans have also been finalized and five others are in advanced stages of finalization.

\section{Social Cluster}

This cluster covers Health, Education, Social Protection, Water and Sanitation, and Youth.

The key achievements in cluster include: the promulgation of new tariffs establishing free Family Planning (FP), with all public health facilities providing free family planning services and care. A community based nutrition strategy was also piloted in 19 districts exceeding the 5 originally targeted.

A training of trainers was conducted in all 30 districts to scale up community treatment of Diarrhea, Pneumonia and Malaria. Provider Initiate Testing (PIT) guidelines have been developed and approved by MINISANTE. 
Three district water resource master plans have been completed as planned and the construction of $490 \mathrm{~km}$ of new water supply systems has also been fully realized.

A total of 153,507 students were enrolled in senior one out of which 123,000 students were in enrolled in the 9 Years Basic Education schools and 27,000 students in other public secondary schools compared to 71,166 students that were enrolled in 2008 .

The percentage of households eligible for support and granted direct support in VUP sectors has reached $100 \%$ exceeding the target of $60 \%$ that was set for $2009 / 10$ fiscal period.

The Cooperative Bank for Youth Self Employment and Development (COOJAD) has opened its offices in 4 Districts: Nyagatare, Rulindo, Nyaruguru and Nyanza.

\section{Governance Cluster}

This cluster covers the following sector working groups: Public Financial Management (PFM), Justice, Reconciliation, Law and Order (JRLO), Decentralization, Citizen Participation, Empowerment, Transparency and Accountability (DCPETA), and Capacity Building and Employment Promotion (CBEP).

The key highlights in cluster include: Itorero program that has been significantly scaled up in the January to June period with more than 60,000 Intore going through the program, in addition to the more than 70,000 who completed the program in 2008.

To increase participation of citizens in decision making, the government has established community forums at cell level known as 'Inteko ya Rubanda'. Public accountability days have also been organized and an advisory council on corruption established.

A specialized unit pursuing economic and financial crimes has been put in place in the National Public Prosecution Authority. The unit is operational and investigates cases of corruption and embezzlement reported by the Office of the Auditor General (OAG).

The Labor code was adopted and gazetted in May 2009. An assessment of the performance of the government budget agencies was completed and a baseline survey on service delivery produced.

In Public Finance Management, the national budget has been aligned with the rest of the East African Community as the first budget for 2009/2010 was read on June 11, 2009. The Debt Management Strategy was completed towards the end of 2008 and a debt manual is currently being drafted that will help in the translation of the strategy into operation.

A number of critical issues that emerge from the self evaluations provided by the different sectors include the following that need a particular attention:

Reinforcing of the Over The Counter (OTC) bond market, further strengthening of the Micro Finance Institutions and accelerating the payment system reforms. A clear long term program for 
issuance of bonds should help to establish a yield curve needed as a benchmark for the pricing of shares and development of the equity market; and subsequent increase in long term financing activity.

The delay in the implementation of the national mosquito net campaign needs to be closely followed up to avoid reversing recent gains made in the fight against Malaria.

There is a slow pace of the transformation of youth associations into cooperatives. The Ministry of Youth should work closer with the Youth Associations and the Rwanda Cooperative Agency to map out strategies to overcome this.

Insufficient materials and infrastructures for the Nine Year Basic Education (9YBE) program and inadequate knowledge of English for teachers in Secondary and Primary schools as a medium of instruction. The training and retention of qualified academic staff in Higher Learning Institutions remain also a major constraint.

There are delays in the release of funds from Districts to VUP sectors and to final beneficiaries. A consideration should be given to shifting the financial and management structure to put more emphasis on the sector level.

The allocation of additional resources for scaling up of Access to Justice Centers (MAJ), capacity building in the areas of investigating financial crimes and scaling up of training of community policing officers needs to be considered. 


\section{Introduction}

This report provides the progress on implementation of the Economic Development and Poverty Reduction Strategy (EDPRS) in the Mini Budget Period of January to June 2009. It is based on the selected Policy Actions in the EDPRS Results and Policy Matrix for January to June, 2009.

The EDPRS Results and Policy Matrix contains the full set of selected indicators, targets and policy actions being monitored by the Government of Rwanda (GoR) at Central level. There are however, a wider range of indicators, targets and policy actions monitored at Sector level than those contained in the Matrix.

The EDPRS Results and Policy Matrix is organised around 3 major strategic objectives of:

1. Increased economic growth

2. Managing population growth rate and enhancing population development

3. Enhanced gains through good governance.

Within each strategic objective there are a number of strategic outcomes, together with associated indicators and targets being monitored at national level as well as related policy actions.

Each EDPRS sector contributes to the implementation of one or more strategic outcomes under the strategic objectives, through its fulfilling of agreed policy actions. Note that, because data collection on performance indicators is at least annual, this report is based solely on policy actions that were to be implemented between January and June 2009, and the progress towards achieving them.

The analysis of performance is based on self assessment provided by each sector on progress at the end of June 2009, together with explanations of why performance has been limited or where progress was slow. The reporting method uses a 'traffic lights' scorecard, which visualises the information in a very accessible and user-friendly way.

The traffic light colour coding rates progress: green indicates that the policy action was 'fully achieved', yellow indicates that the policy action was 'partially achieved' and red indicates that the implementation of the policy action is 'off-track' , 'not met' or was lagging significantly behind.

The report is structured under three Clusters; Economic, Social and Governance, established by the Kivu Leadership retreat of Government. 


\section{Economic Cluster}

This cluster covers the Macro Economic and Financial sector and the economic sectors of Agriculture, Infrastructure (Energy, Transport), Private Sector development as well as Environment and Natural Resources management.

\subsection{Macro Economic and Financial Sector}

5 major Policy actions set; 4 fully achieved and 1 partially met.

The 2009 Gross Domestic Product (GDP) growth projections have been decreased to 5.3\% following the strong performance of $11.2 \%$ in 2008 . This was mainly due to the global economic downturn which negatively impacted demand for exports and the stringent domestic credit conditions. Agriculture however is showing signs of resisting the poor economic climate.

Exports decreased by $21.3 \%$ in volume and by $31.9 \%$ in value during the first half of 2009 compared to 2008, with all exports declining in value expect tea. Imports however maintained an upward trend with an increase in the first half of 2009 of $26.9 \%$ in value and $18.9 \%$ in volume compared to the same period in 2008. Indications are that imports are also set to decline after the set of orders completed in the 2008 boom period are delivered.

Credit to the private sector declined by 3.6\% from an amount of RWF 341 billion in December to RWF 329.4 billion in June 2009. Early indications also show that the construction sector is slowing down after 3 years of strong performance; large companies recorded an increase in turnover of $4.19 \%$ during the first half of 2009 , against an increase of $45.17 \%$ in the same period of 2008. The annual increase in turnover of key players in the industry and service sectors also decreased from $38.93 \%$ and $40.95 \%$ to $7.68 \%$ and $4.68 \%$ respectively in the first half of 2009 compared to the same period in 2008.

Inflation has declined overall from 22.3\% in December 2008 to $10.1 \%$ in June 2009 and the trend is tending towards the objective of single digit inflation. There has also been relative price stability with the overall change in price index at 1.8\% compared to December 2008.

The Rwanda Franc exchange rate was quite stable during the first half of 2009 with a moderate depreciation of 2.3\% between December 2008 and June 2009.

The 2009/2010 fiscal year budget was approved by Parliament in June. The budget is aligned to the East African Community (EAC) budget calendar and represents a $24 \%$ increase from the 2008 fiscal year. It has been aligned to the EDPRS priorities with emphasis on job creation, rural investment, infrastructure and human development

The Micro Finance credit fund has been made operational; the fund will help Micro Finance Institutions (MFIs) to access finance for lending at subsidized rates, by the end of June more than RWF 1.3 Billion had been disbursed to different MFIs. 
As regards putting in place a legal and institutional framework for payment systems; the National Payment Systems Strategy was developed and the Law on Security Interest in Immovable Property and mortgages has been passed in Parliament in April 2009. The National Payments Council (NPC) Decree has been enacted and the NPC has been established and is already providing guidance for payments system development.

A Ministerial Order has been issued calling for larger companies to base their tax returns on International Auditing Standards (IAS) and International Financial Reporting Standards (IFRS) of accounting, the law establishing the Institute of Chartered Accountants of Rwanda (ICPAR) is also in place.

\section{Key issues}

The following are some of the key issues facing the macro economic and financial sector;

- Monitoring closely of the global economic environment to mitigate any potential negative impacts to the Rwandan economy and stimulating economic recovery by improving liquidity in the banking system. Some of the main measures taken by the government to improve liquidity in the banking system include; reduction of the Required Reserve Ratio from $8 \%$ to $5 \%$, roll over of short term treasury bills maturing in 2009 and the introduction of medium and long term refinancing facilities.

- Low savings and low utilization of financial institutions. The Umurenge SACCO policy has been developed and is expected to increase the usage of financial institutions and savings by targeting at least one Savings and Credit Cooperative (SACCO) in each sector (Umurenge).

- The payment systems reforms are dragging and there is need to strengthen the mechanisms for payment systems including SIMTEL.

- The feasibility study for the establishment of a rural micro insurance company was not carried out. The strategy for rural micro insurance which was validated by stakeholders contained 2 options for implementation; either the setting up of a specialized rural insurance company or the development of rural insurance products using existing insurance companies. The latter option was deemed more appropriate and pilot tests for rural micro insurance products carried out involving the Ministry of Agriculture (MINAGRI), SONARWA and tomato farmers.

- On the Over the Counter (OTC) market, although there has been significant activity on the equity market with more than 60,000 shares traded, have been no transactions whatsoever in the bond market over the first 6 months of 2009. This can be attributed to the short term maturity of the existing bonds on the market. A clear long term program for issuance of bonds should help to establish a yield curve needed as a benchmark for the pricing of shares and development of the equity market; and subsequent increase in long term financing activity. 
- There is an urgent need to restructure the Housing Bank of Rwanda (BHR) into a mortgage refinancing company. The business plan for the restructuring is being developed and needs to be accelerated.

\subsection{Private sector}

6 policy targets set; 6 fully met.

Efforts to improve the doing business environment are gaining momentum with a total of 8 licenses identified for action, a more comprehensive survey on investor perceptions has also been completed with a view to getting first hand information related to investors and the business environment.

All borders have been connected to the ASYCUDA (customs software) network except Rutete which is to be connected in the 2009/10 fiscal year. Computerization and implementation of the business registry system for secured transactions and intellectual property rights are also progressing well. The Rwanda Commercial Registration Agency (RCRA) has also begun operations with liaison offices in Muhanga, Rusizi and Huye.

The Industrial Policy is in final stages of completion and is to be validated with the Industrial Master Plan and Rwanda has already begun implementing the EAC Customs Management Act from $1^{\text {st } J u l y, ~} 2009$.

\section{Key Issues}

- Close follow up required for the finalization of the Industrial Master Plan

\subsection{Infrastructure sector}

This sector covers sub sectors of energy and transport in the EDPRS results and Policy matrix.

\subsubsection{Energy sub sector}

5 policy targets set and all fully implemented.

Cost efficient distribution technology for rural electrification has been determined and a directorate setup for implementation of the National Electricity Roll out program in Electrogaz. Energy source diversification has been boosted by the pilot methane gas project producing 2 Mega Watts (MW) to the national grid, the 20 MW Jabana heavy fuel plant was also commissioned and is now operating.

The draft law establishing the Rwanda Energy and Water Development Boards has been submitted to Parliament and the Ministry of Infrastructure (MININFRA) has signed a contract with an independent power producer (Contour Global) in 2009 for the extraction of Methane gas 
from Lake Kivu for production of up to $100 \mathrm{MW}$ of electricity to feed into the national grid, with the first $25 \mathrm{MW}$ expected in September 2010.

\section{Key issues}

- Delay in the rehabilitation of 3 hydro power stations of; Mukungwa, Gihira and Gisenyi due to destruction of contractor headquarters in an earthquake in China.

- Mobilizing of funds for the implementation of the national electricity roll out program. Of the 617 million USD required for implementation of the program (technical assistance and investment) only 228 million USD has been pledged leaving a financing gap of more than $60 \%$ of the total amount required.

- Need to reduce technical and commercial losses which are approximately $20 \%$ and $7 \%$ respectively. The GEF project that is yet to commence, is expected to reduce technical losses to $15 \%$ and commercial losses to $2 \%$.

- There is a barrier of high taxation on equipment for energy infrastructure, $40 \%$ of the cost is spent on taxes.

\subsubsection{Transport sub sector}

7 policy targets set; 4 fully implemented 1 partially met and 2 not met.

The target of periodic maintenance for $20 \mathrm{~km}$ of paved road has been achieved whereas $90 \%$ rehabilitation and maintenance works of the $120 \mathrm{~km}$ national earth roads have been completed.

The Rwanda transport Agency was adopted by Cabinet and the Road Act is in final stages of preparation. The Road Maintenance Fund (RMF) Strategic plan has also been adopted and the evaluation of bids is underway for the Transport Master Plan study.

\section{Key issues}

- Completion of the axle load control system for $50 \%$ of the national paved road network. Inventory work has not yet been carried out as well and this action risks not being completed within 2009.

- The signing of output and performance based road contracts with an additional contractor have also not been implemented and measures need to be taken to address this. 


\subsection{Agriculture sector}

10 policy actions set; 8 fully implemented and 2 partially achieved.

Preliminary estimates suggest that growth in agricultural production was $11.2 \%$ in volume during the seasons A and B of 2009. This comes as a result of continued efforts in crop intensification program and favorable climatic conditions.

Feasibility studies for an additional 17 sites identified under the LWH have been contracted and initiated by the Ministry of Agriculture (MINAGRI). The land consolidation Ministerial Decree draft is being share with stakeholders for inputs.

The fertilizer strategy is being implemented; the private sector is involved in agricultural inputs delivery and distribution through the voucher system. The action plan for fertilizer distribution has also been completed and endorsed by the rural cluster. A draft mechanization strategy has also been completed and is soon to be endorsed by the agriculture sector working group.

The seed policy and 5 year costed action plan were adopted by Cabinet in March 2009. An evaluation study of the implementation of the 'One Cow per Household' has also been completed.

\section{Key issues}

- Policy actions partially achieved were; the adoption and publishing of the Ministerial decree on land consolidation which is still in consultation phases with stakeholders and the review of the implementation of the animal husbandry and zero grazing policy was also commenced but not yet finalized.

\subsection{Environment and natural resources Sector}

9 policy action targets; 8 fully implemented and 1 partially met.

Significant progress has been made in the production of orthophotos for the Country, with $70 \%$ soft and hard copies produced. A draft report of the inventory of the existing land information data has been completed and being presented to stakeholders.

A total of 9,997 land certificates were issued by mid June 2009 representing $67 \%$ of the total adjudicated and demarcated parcels $(14,922)$. Watershed management plans for Rugezi, Kamiranzovu, Rweru-Mugesera and Akagera were validated in March 2009.

Twenty five (25) District Forest Management Plans (DFMP) have been completed. Five other DFMPs for Kicukiro, Gicumbi, Gatsibo, Nyagatare and Bugesera are at advanced stages of finalization. 
The policy actions for the continued improvement in the data collection system is progressing well with 22 limn metric stations in place and data being collected. Tender documents for the rehabilitation of 14 (5 were the original target) hydrological and limn metric stations have been issued while the feasibility study for rehabilitation of Nyabarongo river border has been completed and the one for Muvumba River is to be prepared for fiscal year 2009/10.

\section{Key issues}

- The target not met was for rehabilitation of 5 hydrological and limn metric stations. However, tender documents were launched for 14 stations exceeding the original 5 targeted.

- Closer follow up of tree plantation exercise is required to assess why in some areas there is high percentage loss of trees planted. Overall losses amounted to close to $30 \%$ of the trees planted in 2008 .

Table 1 Summary of Economic Cluster EDPRS Policy actions, 2009 Mini budget

\begin{tabular}{|l|c|c|c|c|c|c|c|}
\hline Score Level & $\begin{array}{c}\text { Macro \& } \\
\text { Financial }\end{array}$ & PSD & Agriculture & Energy & Transport & $\begin{array}{c}\text { Environment } \\
\text { \& Natural } \\
\text { resources }\end{array}$ & Total \\
\hline $\begin{array}{l}\text { Green (fully met/on- } \\
\text { track) }\end{array}$ & 4 & 6 & 8 & 5 & 4 & 8 & $\mathbf{3 4}$ \\
$\mathbf{( 8 3 \% )}$
\end{tabular}

\section{Social Cluster}

This cluster covers Education, Health, Social Protection, Youth and Water and Sanitation.

\subsection{Health sector}

7 policy action targets; 5 fully implemented and 2 partially met.

The Promulgation of new tariffs establishing free Family Planning (FP) services has been achieved with all public health facilities providing free family planning services and care. The framework for the provision of FP services was developed and distributed in all Health Facilities.

All Health centers (100\%) do outreach services for immunization exceeding $15 \%$ targeted for Jan-June 2009. The Nutrition policy has also been approved by Cabinet and the implementation plan developed. A Community based nutrition strategy was piloted in 19 districts exceeding the 5 originally targeted. 
Guidelines for Diarrhea treatment were published and training of trainers for 30 districts was conducted to scale up community treatment of diarrhea, pneumonia and malaria. Deliveries in Health facilities have also been included in all Districts' Imihigo for 2009/10 fiscal period.

Provider Initiate Testing (PIT) guidelines have been developed and approved by Ministry of Health (MINISANTE), a Manual of trainers is currently being developed.

In the fight against the spread of HIV/AIDS and Sexually Transmitted Diseases (STDs), condoms have been integrated in the Community health workers' kits to improve accessibility at community level and the Male circumcision strategy has been integrated in the National Strategic Plan of HIV \& AIDS 2009-2012. The systematic and early testing of children born to HIV positive mothers continues to make headway with $66 \%$ of children born between January and June 2009 tested.

The revised draft of the health insurance policy based on payment according to social economic category is in advanced stages of finalization waiting for submission to Cabinet. Performance Based Financing (PBF) Strategy was also approved by MINISANTE and published on the ministry website.

\section{Key issues}

- Attention should be paid to the finalization of the Revised Health Insurance Policy

- The national campaign for free mosquito nets for under five children, pregnant woman and other vulnerable groups, needs to be accelerated. It was in the tendering process by end June.

- Scaling up of youth friendly centers remains a challenge that requires more resource mobilization.

\subsection{Water and Sanitation Sector}

10 major policy actions, 8 fully implemented and 2 partially achieved.

As regards, the increase in access to clean drinking water, three district water resource master plans have been completed as planned and the construction of $490 \mathrm{~km}$ of new water supply systems has also been fully realized

The draft version of the Water and Sanitation policy has been presented to stakeholders for approval and the Water and Sanitation Management Information system was completed and trainings for staff are being organized.

A total of 253 sanitation facilities were constructed in schools and in Nyaruguru and Nyamagabe settlements. 


\section{Key issues}

- Preparation of the hand book on hygiene and sanitation for teacher and handbook on Hygiene and Sanitation in Schools (HAMS) has not been completed.

- The targets for sanitation facilities in Pilot sectors of each Province were not met although progress was made.

\subsection{Education sector}

8 major policy targets; 7 fully achieved and 1 partially implemented

Two policies have been approved; Special Education Needs policy and Girls' education policy. Costing of strategic plan for the implementation of Girls' Education policy has also been finalized and waiting for validation. Education quality standards have also been approved.

The adoption of a framework and procedures for decentralised procurement and school-level selection of text books has been fully completed. Progress on tender for inclusion on the approved list of teaching and learning materials is that the list has been approved by steering committee.

The $1^{\text {st }}$ draft on the analytical work and studies on post basic education as part of the country status report has been presented to MINEDUC. Regarding the costing of Teacher Development Management (TDM) strategic plan that included coordination of In Service Education Training (INSET) policy, the required expertise has been procured and the Strategy is being developed.

In January 2009, out of 2,432 existing primary schools, 523 received first year students of the lower secondary school (Tronc Commun) in the implementation of Nine Years Basic Education (9YBE) program.

A total of 153,507 students were enrolled in senior one out of which 123,000 students were in 9YBE schools and 27,000 students in other public secondary schools compared to 71,166 students that were enrolled in 2008.

With the help of Education Management Information System (EMIS), a census for education statistics was conducted and data analysis has started. This was one of the major challenges highlighted in the 2008 progress report and it has been marked as a priority.

Currently students' population in public institutions of higher learning is standing at $26,304(48 \%)^{8}$. The female population constitutes $33 \%$ whilst males constitute $67 \%$. On the other hand, the number of students in private institutions is $28,909(52 \%)^{9}$ of which $47 \%$ is male and $53 \%$ is female. An increase by $9.3 \%$ student's enrolment has been registered in the private sector.

\footnotetext{
${ }^{8}$ Percentage of gross students enrolment in all Public and Private HLIs

${ }_{9}^{9}$ Percentage of gross students enrolment in all Private and Public HLIs
} 


\section{Key issues}

- The finalization of the TDM strategic plan

The issues faced regarding the implementation of Nine Years Basic Education include;

- Lack of enough infrastructures to accommodate large number of students that are entering in these newly established schools.

- Lack of enough text books and syllabus in English language since it became a medium of instruction in Rwandan education system. Majority of the text books are in French.

- Lack of enough qualified teacher to teach in these schools more especially science subjects, also most of the teachers are not fluent enough to teach in English.

The issues facing higher education sector include;

- Recruitment, training and retention of qualified academic staff. The number of national academic staff with PhDs qualification is significantly lower than the threshold standard ratio of $\mathrm{PhD}$ holders to the total number of academic staff.

- Lack of explicit policy on staff motivation and retention has been resulting into high rate of staff turnover. In a period of just six months, public Higher Learning Institutions have lost over 81 academic staff that resigned due to reasons mainly attributed to low remuneration.

\subsection{Social Protection Sector}

5 major policy targets; 4 fully achieved and 1 partially achieved.

The Government and Development partners have committed funds for VUP implementation in 30 pilot sectors exceeding the total number of 15 that was expected. Field visits indicate that in some sectors the public works wage rate ratio to market wage rate is equal to or more than 1 . Beneficiaries can decide whether to retain a proportion of their public works wages as savings in the bank and are also being paid directly (not through contractors).

The percentage of households eligible for support, granted direct support in VUP sectors has reached $100 \%$ exceeding the target of $60 \%$ that was set for $2009 / 10$ fiscal period.

The implementation of the Policy action on microfinance is underway through Savings and Credit Cooperatives (SACCOs) which are also being established and/or strengthened in VUP sectors, through which vulnerable households will be able to access credit. The sector is also acting on recommendations to revise the financial services policy and procedures manual.

\section{Key issues}

- Under VUP, some of the underlying problems which require particular attention include; delay in timely disbursement of funds due to delays in project approval. Even when funds are disbursed to the district, there are delays in releasing these funds to the sector for access to the 
beneficiaries. One of the policy recommendations that have been suggested to resolve this delay is the change of the implementation and administration structure of VUP to put more focus on the Umurenge or sector level and reduce the District level administration.

\subsection{Youth Sector}

2 policy targets; both fully achieved.

With effect from January 2009, Cooperative Bank for Youth Self Employment and Development (COOJAD) has opened its offices in 4 Districts of; Nyagatare, Rulindo, Nyaruguru and Nyanza. However, they are still waiting for approval from National Bank of Rwanda (BNR) and the Ministry of Commerce (MINICOM) to start giving loans.

Currently, COOJAD has 2928 Members. In 2009 January to June, 163 members were given loans and the number of new jobs generated is estimated at 628 . The support provided by the Ministry of Youth (MINIYOUTH), National Youth Council (NYC) and the above mentioned Districts to the youth Savings and Credit Cooperatives (SACCO) is in form of wages, purchase of office equipments and other administrative costs.

The action to prepare diversified cooperatives has yielded a total of 36 cooperatives supported. Youth associations are helped through sensitization, training and funds allocation.

\section{Key issues}

- The transformation process is moving at a slow pace because of insufficient knowledge to develop all documents required to be guaranteed a legal personality, mistrust among the members of associations and resistance to change on the part of youth. Consequently, the Ministry of Youth is working closely with the concerned parties notably the youth themselves and Rwanda Cooperative Agency to rectify the problem.

Table 2 Summary of Social Sector EDPRS Policy actions, 2009 Mini budget

\begin{tabular}{|l|c|c|c|c|c|c|}
\hline Score Level & Education & Health & $\begin{array}{c}\text { Social } \\
\text { Protection }\end{array}$ & $\begin{array}{c}\text { Water and } \\
\text { Sanitation }\end{array}$ & Youth & Total \\
\hline Green (fully met/on-track) & 7 & 5 & 4 & 8 & 2 & $\mathbf{2 6}(\mathbf{8 1 \%})$ \\
\hline Yellow (Partially met) & 1 & 2 & 1 & 2 & 0 & $\mathbf{6}(\mathbf{1 9 \%})$ \\
\hline Red (off track) & 0 & 0 & 0 & 0 & 0 & $\mathbf{0}$ \\
\hline
\end{tabular}




\section{Governance Cluster}

The governance cluster brings together four sector working groups related to the areas of Public Financial Management (PFM), Justice, Reconciliation, Law and Order (JRLO), Decentralization, Citizen Participation, Empowerment, Transparency and Accountability (DCPETA), and Capacity Building and Employment Promotion (CBEP).

\subsection{Capacity Building and Employment Promotion Sector}

5 major policy targets; 4 fully implemented and 1 partially achieved.

The internship program that had failed to take off in the 2008 fiscal year was finally launched with 100 youth initially being taken on board to different government institutions.

The Labor code was submitted to cabinet and published in the Official Gazette in May 2009. An assessment of the government budget agencies achieving more than $80 \%$ of their work outputs was completed and a baseline survey on service delivery has also been completed with a first draft presented to stakeholders for validation. A capacity building plan draft has also been developed awaiting validation by stakeholders.

The Ministry of Public Service and Labor (MIFOTRA) was in the process of negotiations with Central Ministries to determine appropriate staffing levels and structures for optimal performance within fiscal limits. An assessment of current staff is ongoing to ensure high quality professional staff are retained and engaged in the agreed positions.

\section{Key issues}

- Resource mobilization remains a challenge for the youth internship program.

- Associated with the new staffing structures is a challenge of ensuring efficiency of the new structures.

\subsection{Decentralization, Citizen Participation, Empowerment, Transparency and Accountability (DCPETA) Sector}

4 major policy targets; 3 fully implemented and 1 partially achieved.

District capacity building plans are in place and their respective plans developed. A number of training programs for Community Development Committees (CDC) and Tax Advisory Councils have already been conducted. New local administrative structures have been developed with increased staffing at sector and cell level to further decentralize and improve service delivery.

To increase participation of citizens in decision making, the government has established community forums at cell level known as 'Inteko ya Rubanda'. Public accountability days have also been organized and an advisory council on corruption established. 
To further strengthen the electoral process, a draft Law establishing the Organization and functioning of the National Electoral Commission in place but yet to be sent to cabinet for approval. A draft Law on Charter on Democracy on election was passed and the Electoral code was drafted and was meant to be presented to Cabinet in the first quarter of 2009/10.

Itorero program has been significantly scaled up in the January to June period with more than 60,000 going through the program in addition to the more than 70,000 who completed the program in 2008.

After the completion of a study on social cohesion, another study termed the 'Reconciliation Barometer' is underway and is expected to provide a measure of progress made in good governance and reconciliation to support the sector in evidence based planning.

The program for integration of released genocide suspects is also on track following its inclusion in the district performance contracts for 2009/10.

\section{Key issues}

- The Itorero program targets were too ambitious and need to be either downscaled or more resources mobilized, the target for the mini budget period was to reach 350,000 and yet the target for 2008 was also not achieved by some margin.

\subsection{Justice, Reconciliation, Law and Order sector .}

14 major policy targets; 10 fully implemented and 4 partially achieved.

A Justice sector needs assessment is in advanced stages of preparation and a Prime Minister's Decree legally establishing Justice sector technical committees at District level is being finalized.

With regards to the popularising of laws on corruption and accountability, this has been done through sensitisation on the fight against corruption working with different media. Two high level meetings were organized between the National Public Prosecution Authority (NPPA) and the Rwanda National Police (RNP) to exchange ideas on strategies to fight economic and financial crime in financial institutions.

The organic frame of NPPA and a specialized unit pursuing economic and financial crimes has been fully completed. The specialized unit is operational and investigates files of corruption and embezzlement reported by the Office of the Auditor General (OAG).

The efforts to further reduce pressure on prison infrastructure are progressing well with the expansion of Butare prison. With regard to construction of Butamwa prison, the tender process was launched and the expropriation exercise was $70 \%$ completed and construction was scheduled to commence immediately after completion of the expropriation exercise. 
In order to accelerate TIG activities, 58 operational TIG work camps have been opened with a total of 23,580 convicts undergoing their sentence. An estimated net revenue of RWF 4.4 Billion was realised from different development projects that were undertaken through the TIG program.

A total of 42,223 persons were trained in human rights related aspects in different schools and through solidarity camps. In addition to this more than 1, 000 historically marginalized persons underwent the same training as did 167 members of prison services, 60 persons from religious groups and 29 people living with HIV/AIDS.

Training on community policing have also been carried out in conjunction with local governments to liaison officers and some community policing committees, with a view to reinforcing the gains made in crime reduction in 2008.

The Ministry of Justice (MINIJUST) has identified 10 Districts for scaling up 'Access to Justice Centers' (MAJ) to increase access to Justice. A total of 6 MAJ will be setup this year.

As far as speeding up of judgement execution, MINIJUST in addition to other ongoing initiatives is organizing a legal aid week for children aimed at speeding up cases of children under detention.

In reduction of the case backlog, tried cases during the mini budget period were 32,690 representing $43 \%$ of the backlog.

\section{Key issues}

- The following actions are not progressing rapidly enough and need to be closely followed up; the justice sector needs assessment, construction of Butamwa Prison, and training of members of cooperatives on human rights.

- The reinforcement of Justice Committees at District level through capacity building was not implemented. A Prime Ministerial Order legally establishing the District Technical Committees has yet not been finalized.

- There is need for capacity building for the NPPA in areas of economic crimes, accountability, and audit and bank documents, especially now that a specialized unit has been formed to address the mentioned areas.

- There is a need to scale up community policing trainings and equipping of Community policing liaison officers (CLOs).

- It is unlikely that the target of 10 MAJ will be met by December 2009 unless there is sufficient resource mobilization to set up the remaining 4 that are not yet in place. 


\subsection{Public Finance Management (PFM) Sector}

11 major policy targets; 7 fully implemented and 4 partially achieved.

Gender Based Budgeting was introduced at beginning of 2009. An institutional frame work for the technical team and the steering committee has been instituted. A training manual has been developed and gender based monitoring and evaluation framework has been put in place and sensitization workshops for both local and central government have been undertaken.

The national budget has been aligned with the rest of the East African Community as the first budget for 2009/2010 was read on June 11, 2009. The Debt Management Strategy was completed towards the end of 2008 and a debt manual is currently being drafted that will help in the translation of the strategy into operation.

Capacity building initiatives for financial and accounting staff is on course being provided through on-job training, and ACCA training was re-launched in 2008 and is being provided and funded by the Government.

On the action to ensure that each budget agency submits a fund accountability statement, GoR developed a Financial Reporting Template (FRT) that is used by all Budget Agencies when preparing year end financial statements. Most budget agencies have submitted financial statements for 2007 and 2008 in line with the FRT within the stipulated timeframe. Government has used the same template for the preparation of consolidated financial statements for the year ended 31 December 2008.

In order to ensure adequate satisfaction on the development and implementation of SmartFMS, a team (Quality Assurance Group) was put in place and has completed the first mission of an independent quality assessment of the development of IFMS in April 2009. This team recommended among other things; that the testing and piloting be extended for an additional year.

An Internal Audit Charter was adopted and published on the MINECOFIN website. The Charter also has a code of ethics for the internal audit staff. A number of workshops have been carried out to sensitize the stakeholders on these new vital instruments.

The Office of the Auditor General (OAG) is carrying out comparisons of the different audit software used in various Supreme Audit Institutions to select the most suitable software for installation.

With regard to the analysis and compilation of reports on fiscal risks posed by Government Business Enterprises (GBEs), the $43 \%$ target has been met and exceeded as all GBEs have submitted fiscal reports in 2008 and the number is on the rise for the mini budget. 
A memorandum of Understanding between Rwanda Public Procurement Authority (RPPA) and Rwanda Institute of Administration and Management (RIAM) was signed to develop curricula for provision of basic training in procurement.

\section{Key issues}

- More training required to institutionalize gender based budgeting techniques.

- Key PFM Secretariat personnel haven't been recruited hampering the speed of some of the reforms. A PFM Reforms coordinator, an accountant and Procurement Management Specialist need to be contracted as soon as possible so as to reinforce the team.

Table 3 Summary of Governance Cluster EDPRS policy actions, 2009 Mini Budget

\begin{tabular}{|l|c|c|c|c|c|}
\hline Score Level & PFM & JRLO & DCPETA & CBEP & Total \\
\hline Green (fully met/on-track) & 7 & 10 & 3 & 4 & $\mathbf{2 4}$ (71\%) \\
\hline Yellow (Partially met) & 4 & 4 & 1 & 1 & $\mathbf{1 0}(\mathbf{2 9 \%})$ \\
\hline Red (off track) & 0 & 0 & 0 & 0 & $\mathbf{0}$ \\
& & & & & \\
\hline
\end{tabular}

\section{Summary of emerging issues}

The Mini Budget period of 6 months was a relatively short period of time to implement some of the policy actions. A significant percentage of policy actions were only partially achieved.

Overall, a total of 107 policy actions were to be implemented in the mini-budget period of 2009. Out of these; a total of $84(79 \%)$ were fully achieved, $21(19 \%)$ were partially achieved and 2 $(2 \%)$ were lagging significantly behind or had not commenced by the end of June 2009. There are a number of critical areas that need to be addressed in 2009/2010 fiscal year;

- Revival of the OTC market, strengthening of the MFI and more follow up on the payment reforms system especially with respect to the electronic payment system.

- Funds mobilization for the scale up of the National Electricity Roll out program.

- Completion of the axle load control system for the national paved road network system.

- Scaling up of youth friendly centers in the health sector has still not been addressed and delay in the implementation of the national mosquito net campaign may hamper the fight against malaria. 
- Recruitment, training and retention of qualified academic staff in HLIs, insufficient equipment for the 9YBE program and inadequate knowledge of the English language among teachers using it as a medium of instruction.

- Addressing the delays in releasing funds to the Sector (Umurenge) level for access to beneficiaries in the VUP program.

- Resource mobilization for scaling up of Access to Justice Centers (MAJ) capacity building in the areas of financial crimes and scaling up of training of Community policing officers.

- Closer follow up the tree plantation exercise and analysis of the reasons for failure in some areas to sustain growth.

\section{Annex Provinces}

\section{Kigali City}

\section{Economic Development}

\section{Housing and land use management}

End 2008 saw Kigali City with a City master Plan that guided the City in its urban development and physical plans for few identified areas covering a total area of 288ha. The first half of 2009 was pre occupied with communicating the Masterplan to all stakeholders and developing detailed physical plans for Nyarugenge Districts. The draft report has been published and the final report is due in October. Physical plans for 470 ha of residential area with 35,000 plots were developed (Rugarama 1,023, Kagarama 360, Masaka 386, Murama 2,000 and Kagugu 2,000 plots) and 463 ha of commercial sites were also developed including 60 ha in Rebero and 53ha in Kimihurura and the Central Business District.

In a bid to promote government policy on settlement, the City has identified a total of 40 sites to develop into settlements commonly known as "Imidugudu" and District performance is as follows;

\begin{tabular}{|l|l|l|l|l|l|}
\hline District & $\begin{array}{l}\text { No of sites to } \\
\text { develop }\end{array}$ & $\begin{array}{l}\text { No of sites } \\
\text { developed }\end{array}$ & Hectares & $\begin{array}{l}\text { Total No of } \\
\text { plots }\end{array}$ & of completion \\
\hline Kicukiro & 6 & 6 & 133 ha & 2,400 & $100 \%$ \\
\hline Nyarugenge & 11 & 11 & 165 ha & 3,300 & $100 \%$ \\
\hline Gasabo & 23 & 9 & 180 ha & 2,350 & $39 \%$ \\
\hline Total & $\mathbf{4 0}$ & $\mathbf{2 6}$ & $\mathbf{4 7 8}$ ha & $\mathbf{8 , 0 5 0}$ & $\mathbf{6 5 \%}$ \\
\hline
\end{tabular}

Kigali City developed and adopted a Clients Charter to guide the Land offices in harmonizing and improving services in the Districts. As a result, it takes only 15 days to acquire Deed plans and Lease Contract to those who fulfill the necessary requirements and 30 Days for a Building Permit. 1n the first half of 2009, 3006 Building permits were issued compared to 521 issued in the year 2008 and 2136 Deed plans/Lease contracts were issued against 657 issued in the year 2008 . 


\section{Infrastructure development}

Infrastructure development in Kigali City was high on the agenda in the first half of 2009. The City spent over 6 billion in the construction of several infrastructural facilities in the City. The table below shows expenditure per type of infrastructure.

\begin{tabular}{|l|l|l|}
\hline Type & Size & Amount in Frw \\
\hline Tarmac roads & $1.76 \mathrm{~km}$ & 288 Millions \\
\hline Stone paved roads & $15.8 \mathrm{~km}$ & 2,5 Billion \\
\hline Side walks & $7.5 \mathrm{~km}$ & 736 Millions \\
\hline Pot hall filing in City roads & $10,700 \mathrm{~m} 2$ & 275 Millions \\
\hline Ravines /Drainages & 9 sites & 2,1 Billion \\
\hline Repair of traffic Lights and street lights & 14 sites & 97 Millions \\
\hline New studies for extension of road network in the City & $283.7 \mathrm{~km}$ & 367 Millions \\
\hline Total Amount & & $\mathbf{6 . 3 6 3}$ Billion \\
\hline
\end{tabular}

\section{Financial resource mobilization}

From January to June, all Districts in Kigali City mobilized 4,379,989,797 frw from their domestic revenue sources. $30 \%$ of this money, equivalent to $\mathbf{1 , 3 1 0 , 9 7 9 , 5 4 0}$ frw was transferred to Kigali City Council as provided by the law.

\section{Development of Agriculture and Livestock}

Kigali City developed Urban and Peri Urban Agriculture strategic plan and was adopted by both the City Council and Ministry of Local Government as provided by law. This strategic plan spells out the measure and strategies to increase production and add value to the agricultural produce in Kigali City so as to ensure food security and production for export.

In a bid to ensure efficient land utilization for both settlement and agricultural puposes, Kigali City has embarked to land consolidation measures. In the first six months of 2009, a total of 658.61 ha of land has been consolidated in all Districts, with 312ha, 175.6ha, 171.01ha for Gasabo, Nyarugenge and Kicukiro respectively.

Under one cow one family program, a total of 279 cows were distributed to families in Kigali City, where Nyarugenge district alone distributed 152 cows, Gasabo 67 and Kicukiro 60 in the first half of 2009.

\section{Job creation}

A total of 1,521 people have benefited from Vision 2020 Umurenge program in Kigali City where Kicukiro has provided 600 jobs in public works, Gasabo 526 and Nyarugenge 395. In the direct support component, Kicukiro provides for 299 people, Nyarugenge 201 and Gasabo 149. These programs have had a direct impact in improving peoples' livelihoods. However, the City hardly takes stock of jobs created in other sectors such as construction, service and commercial sectors. 


\section{Good governance and Justice}

Kigali City values resident's participation in community work "Umuganda", the average participation level for Kigali City residents is estimated at $87 \%$ with the total value of Umuganda activities estimated at $612,861,433 \mathrm{frw}$ for the first half of 2009.

Quarries were addressed in the first half of 2009 in Kigali City at 81\%, with Nyarugenge district addressing 408 quarries out of 516 brought to the administrations attention. Gasabo resolved 188 out of 222 and Kicukiro 197 out of 251 queries recorded.

Abunzi program was instrumental in solving minor disputes between individuals the City, in the mini budget period alone, Nyarugenge district resolved 313 cases out of 371 registered, equivalent to $84.3 \%$, Kicukiro district ruled on 119 cases out of 126 (94\%) and Gasabo district resolve 89\% of the cases recieved.

6,539 convicts worked under TIG program in the first half of 2009 in the three districts combined. The value of their labour was estimated at 1,183,599,775 frw. Gasabo had 3.335 convicts working on different district projects and the value of their labour was estimated at $766.671 .500 \mathrm{frw}$, Kicukiro district used 904 convicts and valued their labour at $121.451,900$ frw. Nyarugenge involved 2300 convicts in the program at 295.476.375 frw labour value.

GACACA cases are close to completion in Kigali city, a total of 119 cases in category one, 56 in category two and 84 cases in category three remain. Breakdown per each district are as follows; Nyarugenge: Cat $1=24$, cat $2=0$ cat $3=0$, Gasabo: Cat $1=47$, cat $2=36$ cat $3=18$, Kicukiro: Cat $1=48$, cat $2=20$ cat $3=66$.

\section{Provision of social services}

Social service provision in Kigali City is central to the wellbeing of the people. Its in this regard that the City puts much emphasis is addressing issues to do with Health, Education, and meeting the needs of the vulnerable groups.

In the first half of 2009, 41,424,600 frw has been mobilized into the Education fund with in Kigali City. This fund supports poor children that would not otherwise have means to be in school to go to school. Kicukiro, Gasabo and Nyarugenge mobilized 29,770,000 frw, 7,454,600frw, 4,200,000 frw respectively.

Access to health services in Kigali has improved, 92,4\% of Gasabo District population have access to health Insurance, in Nyarugenge district $92,7 \%$ of the population has got health insurance and in Kicukiro, $80,4 \%$ of its population is in "Mutuelle" health insurance. $43 \%$ of women practice modern family planning methods in Gasabo district, $15.6 \%$ in Kicukiro and 33.8\% in Nyarugenge. 41,167 people undertook Voluntary HIV tests during the course of the first half of 2009 in Kigali City where Kicukiro tested 19,278, Gasabo 12,723 and Nyarugenge 9,166 people. Nyarugenge had 83,5\% of assisted birth, Kicukiro 44,2\% and Gasabo 62,2\% in the first half of 2009.

In all districts, a total of 43 new houses were built for the vulnerable, 83 houses for 2008 were completed, 81 other houses that were built in 2008 are being completed and 10 new plots have been identified for construction. 60 orphans were connected to foster parents in the six months.

\section{Key challenges}

- Huge expropriation costs that result from infrastructure extension and city restructuring and development.

- Existing infrastructure network (water, electricity and roads) is inadequate and needs to be improved and extended in order to accommodate projected future growth.

- Weak Monitoring and evaluation system to take stock of all development trends in Kigali City.

- Unregulated and chaotic intra and inter - City public transport.

- Increasing cost of living in the City

- Human capacity gap 


\section{Recommendations}

- Improving the City's financial resource mobilization capacity to match the financial resource needs of the city.

- Extension and improvement of the City infrastructure network (roads, water, electricity, drainage, landfill... etc)

- Capacity building strategies and programs should be put in place.

- There is need to establish a strong monitoring and evaluation system that can track socio-economic trends in the City.

- Public transport has to be further regulated to provide the most reliable service possible especially for intra City travels.

- There is need to bring down the cost of living in the City that has parachuted in last few years and is becoming increasingly unbearable for the low and irregular income earners.

\section{EASTERN PROVINCE}

\section{KEY ACHIEVEMENTS:}

- There has been $65 \%$ growth of Horticulture crops in Kayonza District.

- Also one cow one family program has been successful with the Districts of Kayonza distributing 153/400(38\%), Rwamagana 358, Gatsibo 500/417 and 130Households have exotic breeds in Bugesera.

- Agriculture and livestock sector has been impressive with in the Province in that 2,640,537,900Frw was generated by the community in Kayonza and 16,379,656,010Frw in Kirehe respectively.

- Land has been protected against soil erosion through construction of terraces on 24.5 Ha in Kayonza, 28\% of land in Rwamagana has been also protected, 16,422 $\mathrm{Ha} \mathrm{(81 \% )} \mathrm{in} \mathrm{Nyagatare,} \mathrm{22,082Ha} \mathrm{(91 \%} \mathrm{protected} \mathrm{against}$ soil erosion) in Kirehe, $485 / 563 \mathrm{Ha}(86.1)-70.2 \%$ protected against soil erosion and $500 \mathrm{Ha}(20.5 \%)$ in Bugesera.

- The Environment has been also conserved through tree planting in the Districts of Kayonza 23.5 Ha of land were planted on and 1005/732Ha (132.3\%) in Gatsibo.

- $1180 / 1,252$ of TIG were used in Kayonza raising a productivity of 50,534,200Frw, in Rwamgana TIG value was at 337, 190,000FRw, in Nyagatare 300 Tigistes constructed a road worth $136.5 \mathrm{M}$ and in Bugesera 3118 Tigistes were used to generate 33.394.400 Frw

- 65169 / 78980 of the community participated in Umuganda with the value of works being $122,164,810 \mathrm{~F}$, in Nyagatare $91 \%$ report for Umuganda and the value of works is at $65 \%$, in Kirehe $78.3 \%$ participated and the value is $230 \mathrm{Frw}$, in Gatsibo the value was $166,445,920 \mathrm{FRW}$ and in Bugesera the number of participants was $148053 / 169145(87.5 \%)$ and the value was at $81.286 .930(54.1 \%)$.

- Mutual insurance in Kayonza is at $94 \%$, in Rwamagana it is at $90 \%$, in Ngoma it is at $87 \%$ and Bugesera at $78.4 \%$.

- 416/463 Gacaca cases were judged in Rwamagana, 595 cases in Ngoma, 202/228(88.6\%) in Gatsibo and 358 $1382(97.7 \%)$ in Bugesera.

- $152,943,510 \mathrm{~F}$ revenues were generated in Rwamagana; $102.1 \mathrm{M}$ (77\%) were generated in Kirehe, 205,061,167Frw in Ngoma and 105,723,509Frw/131,552,257(80.4\%) in Gatsibo.

- In Rwamagana 29 252/48 754HH (60.5\%) have livestock and the District has promoted coffee growing in that at least $100 \%$ of coffee seedlings that were planned to be planted have been planted.

- $1,071 \mathrm{~T}(30 \%)$ of food has been stored for ensuring food security in Nyagatare.

- Mechanization has been promoted through purchase of 8 tractors in Nyagatare and in Gatsibo 1 tractor was bought and one chopper.

- $65.7 \%$ of Nyagatare residents access clean and portable water.

- 12 cooperatives were created in Kirehe district and 8 Non Agricultural jobs were created.

- In Ngoma 306/335 LDFs have been trained and also in the same District 80,10Ha of land were consolidated on selected crops as well as $7456 \mathrm{ha} / 7643 \mathrm{ha}(98 \%)$ in Gatsibo.

- $\quad 31 / 31$ trading centers have been renovated in Gatsibo District.

- In Bugesera 4/3 targeted (133\%) Health centers have been installed with Solar Energy.

\section{CHALLENGES:}

- Corruption in the service provision at all levels hence a lead to luck of transparency and accountability.

- Increased Crimes as a result of drug use 
- Increasing population due to high fertility rate, rural to rural migration, urban to rural migration to mention but a few.

- Rural to Rural Migration and Urban to Rural migration.

- Limited capacity at all levels.

- Limited food storage which can result to food insecurity.

- Nutrition problems in some areas which end into malnutrition.

\section{RECOMMENDATIONS:}

- More classrooms need to be constructed for the promotion of Nine Year Basic Education.

- Tourism promotion and cooperatives need to be promoted and Strengthened

- There is need to foster on the promotion of Public Private Partnership in promoting the Agriculture sector.

- Promotion and strengthening of cooperatives

- Value addition for exports need to be emphasized for both local and international markets.

- Irrigation promotion through use of rainfall and water from the swamps for long term use even during the dry spell.

- Food security through food storage needs to be reemphasized.

- Strengthening SACCOS and other credit and saving schemes.

- Green house promotion in all provincial sectors

- Piloting Hill side Rice growing in all Districts

- Sanitation and cleanliness promotion in most public places

- Care and support the most vulnerable poor groups.

\section{NORTHERN PROVINCE}

\section{I- KEY ACHIEVEMENTS}

The keys achievements which have been observed from January to June 2009 in the Northern Province are summarized as below:

\begin{tabular}{|l|l|l|l|}
\hline INDICATORS (Units) & Target & Realization & \% \\
\hline ECONOMIC SECTOR & & & \\
\hline Radical terraces (Ha) & $1.278,0$ & $1.875,23$ & 146.7 \\
\hline Progressives terraces (Ha) & $34.530,0$ & $38.943,90$ & 112.7 \\
\hline Crop Intensication program: & & & \\
\hline$-\quad$ Wheat (T) & $9.021,0$ & $9.853,55$ & 109.2 \\
\hline$-\quad$ Irish Potatoes (T) & $108.991,0$ & $142.080,30$ & 130.3 \\
\hline$-\quad$ Maize (T) & $6.860,2$ & $8.990,88$ & 131.0 \\
\hline$-\quad$ Beans (T) & $16.994,29$ & $19.992,50$ & 117.6 \\
\hline$-\quad$ Maracouja (T) & - & $4.983,70$ & - \\
\hline Number of Storage facilities & 13 & 15 & 115 \\
\hline Tree Plantation (Ha) & 8.580 & 9.073 & 105.7 \\
\hline Cow Distribution Program (Girinka) & 1.575 & 2.565 & 162.8 \\
\hline Construction of milk collection centers & 10 & 9 & 90.0 \\
\hline Water Distribution (\%) & - & 48.5 & - \\
\hline Roads Maintenance (Km) & 520.5 & 814.0 & 156.4 \\
\hline Resettlement (population in Imidugudu) & 19.374 & 18.680 & 96.4 \\
\hline Energy (Number of households with): & & & \\
\hline$-\quad$ ELECTROGAZ & - & 27.294 & - \\
\hline$-\quad$ Biogas & - & 92.0 & - \\
\hline$-\quad$ Solar energy & - & 184.0 & - \\
\hline SOCIAL WELFARE & & & \\
\hline Health insurance Scheme (\%) & 80.6 & 114.6 \\
\hline
\end{tabular}




\begin{tabular}{|l|l|l|l|}
\hline INDICATORS (Units) & Target & Realization & \% \\
\hline Number of women with births assisted & 27.336 & 13.831 & 50.6 \\
\hline $\begin{array}{l}\text { Children immunized against measles (\% of 11- 23 } \\
\text { months old) }\end{array}$ & 90.22 & 97 & 107.5 \\
\hline Births attended by skilled personnel (\%) & 54 & 58.6 & 108.5 \\
\hline $\begin{array}{l}\text { Modern contraception prevalence (\% of 15- 49 } \\
\text { years old women) }\end{array}$ & 22.1 & 35.7 & 161.5 \\
\hline Primary school net enrolment (\%) & 100 & 98.4 & 98.4 \\
\hline Primary school completion rate (\%) & 100 & 76 & 76 \\
\hline 9 Years Basic Education & 20.788 & 18.892 & 90.9 \\
\hline Reduction of Pupils/Teacher & 65 & 46 & 70.8 \\
\hline Construction of Houses for vulnerable people & 3.476 & 3.309 & 95.2 \\
\hline GOOD GOVERNANCE and JUSTICE & & & \\
\hline Umuganda realizations (FRW) & - & 751.920 .209 & - \\
\hline Gacaca (Execution) & 37.385 & 28.934 & 77.39 \\
\hline
\end{tabular}

\section{II- CHALLENGES ENCONTOURNED}

- Mountains with high slopes continue to be source of erosion,

- Insufficiency of human and financial resources in the province Administration is a handicap to service delivery,

- Landlocked nature of the Northern Province at Kinihira leads to prioritization of the project for a main road construction (Base- Kinihira- Gicumbi- Nyagatare),

- Lateness of some partners to provide their district budget supports which cause some difficulties in realizing new programmed projects

- Lateness in realization of Resettlement Program (Imidugudu) caused by high prices of plots

- Lateness and insufficient agricultural inputs (seeds, chemical fertilizers and....) are the main difficult of CIP realization in the districts.

- Some"Banque Populaire du Rwanda" sub-branches have been slow in delivering loans for "Girinka" program.

- Job creation program has been missed by the fact that projects do not use HIMO approach correctly.

\section{WESTERN PROVINCE}

\section{KEY ACHIEVEMENTS}

- In the program of land use consolidation, the total surface area of $17944 \mathrm{Ha}$ was consolidated and this considerably increased output per hectare.

- 5,975 families gained cows through Girinka program and by means of 'Magirirane' program that is famous in Ngororero District.

- In sector of employments promotion, 7146 new jobs were created throughout the Western Province.

- $113492.4 \mathrm{Ha}$ of land In the Western Province were protected against soil Erosion by use of radical terraces and ditches. This is a big number which is an indicator that by 2010 soil erosion will have been eradicated in the Western Province. 
- In the field of Cooperatives promotion, 172 new cooperatives were formed and operational in the Western Province and this increased the chances of gaining employment opportunities by the population.

- In the program of supporting vulnerable families to gain houses/shelter, 2107 houses, the activities for constructing them were finished as this was ongoing activity; it helped 2107 families to gain shelters.

- In the Program of nine year basic Education, 174 Secondary schools were introduced, this increased considerably the number of students joining secondary schools.

- $89 \%$ of the Western Province population was covered under the health insurance scheme MUSA.

- In savings, 128,222 individuals opened accounts with financial institutions and are working with their respective banks/Microfinance and now benefiting from advantages of working with financial institutions.

- In the field of settlement in Imidugudu, $24.7 \%$ of the Western Province Population are now living in form of Imidugudu.

- $79 \%$ of birth was assisted in the health facilities.

- Extra 1417.14 Ha of Land were prepared and tea were grown and extended on this size of land throughout the Western Province and 24,671,678 seeds were planted.

\section{Challenges}

- There is a problem of baseline in statistics in the Districts.

- There is a problem lack of clear Monitoring and Evaluation Systems in the Districts.

- There is a problem of lack of clear and common indicators for evaluating imihigo.

- There is a problem of re-settle ling families that were residing in Gishwati natural forest and fighting soil erosion over slopes of Gishwati.

- Settlement in Imidugudu is still a challenge as result of failure to get plots and compensation for the plots were Imidugudu sites were identified.

- There is a challenge in implementing land consolidation program.

\section{Measures to overcome Challenges}

- There has been development of Provincial Monitoring and Evaluation framework, which is pending validation, as result, the Districts will be assisted to develop their own Monitoring and Evaluation framework.

- There has been process of developing data base at the District level, forms are being developed and others extracted from Monitoring and Evaluation framework.

- There is continued need to resettle families that are currently living in Gishwati forest.

- There has been the program of planting "Imicaca" as driven need to curb soil erosion in Gishwati forest.

- There has been several campaigns on improving the settlement activities through Imidugudu, the sensitization is ongoing.

\section{SOUTHERN PROVINCE}

\section{KEY ACHIEVEMENTS/REALIZATIONS}

- The Crop Intensification Program (CIP) has been implemented and considerably reduced the hunger and poverty in Southern Province: during these 6 months, Cassava have been cultivated on 18208 ha, Coffee on 3432 ha (in 
all Districts), maize on 3861 ha(in all Districts, especially in Nyanza, Gisagara, Kamonyi and Ruhango) and tea on 522 ha in Nyaruguru and Nyamagabe. Increase in agricultural productivity has been observed as below:

- $\quad$ Coffee: $6.7 \mathrm{~kg} /$ tree

- $\quad$ Cassava: 25 tonnes/ha

- $\quad$ Maize zm607: 2.8 tonnes/ha

- Maize Hybrid: 6.5 tonnes/ha

- Potatoes: 20 tonnes/ha

- $\quad$ Rice: 4.5 tonnes/ha

- $\quad$ wheat: 2.3 tonnes/ha

- $86.7 \%$ of the total area of the Southern Province are protected against soil erosion by adequate erosion control infrastructures;

- All the Districts of the southern Province finalised and approved the forest master plans (each by District) and are being implemented;

- 2149 agglomeration sites have been identified, mapped with GPS and basic infrastructures continue to be put in place (roads, water and electricity). Houses parcels in the sites have been traced and some attributed to owners for construction.

- Performance contracts have been evaluated in all Districts and all Districts signed performance contracts with important development partners (NGOs and projects);

- 882 local defence have been trained to totalize 3237 . The decrease of 50.7\% in number of crimes comparing the first six months in 2008 and 2009 is due to the work done by the community policing committees, the security organs, the public institutions as well as the contribution of civil society organisations in security maintenance.

- 531 anti-Gender Based Violence clubs have been created in all Cells (one anti-GBV club in each cell);

- The consultative committees on fighting against corruption and injustice have been put in place at Provincial and District levels; and anti-corruption messages are posted on every door of all the government administrative institutions' offices ;

- An assessment targeting the Unity and reconciliation clubs has been conducted in 96 secondary schools and a unity and reconciliation forum has been created in each District;

- Championed by the Provincial Business Development Forum (PBDF) put in place in March 2009, the customer care development campaign has been conducted in the Southern Province:

- The customer care evaluation conducted has targeted 531 cells (public institutions ) and 152 private businesses;

- Awareness sessions have been organized, communication and information on customer care development have been provided and provincial customer care awards have been offered to 32 best Cells, the best Hotel, the best motel, the best restaurant, the best supermarket and the best financial institution;

- Gacaca cases have been judged at the rate $99,7 \%$ for second category, and at the rate of $89,6 \%$ for the first category. Emphasis put in judgement execution drive to a progress of $67.4 \%$ as execution rate for Gacaca third category cases;

- Drop out rate in primary schools has been decreased to $1 \%$ and Nine years Basic Education program is implemented in 122 schools. The Provincial Education Task force has been put in place;

- 5259 poor and vulnerable families were targeted to benefit from shelter program in favour of vulnerable groups: 5024 houses have been finished, 686 houses are under construction;

- $\quad 92 \%$ of the population have been covered under the health insurance scheme;

- 5 Districts (Gisagara, Huye, Nyaruguru, Nyanza and Kamonyi) supported the youth initiatives in Youth Credit and Saving Cooperative(COOJAD) consolidation and women in all Southern Districts are organizing in KIRA (Koperative Ishema Ry'Abagore);

- Every village chose a hill of excellence (agasozi ndatwa) and special inputs were targeting the acceleration of the integrated development though this program. An evaluation of this program has been conducted in all Districts; 
- A study on the big cassava processing company has been done, the command of the processing machine for this industry to be placed in Ruhango District has been passed.

- Nine cassava processing small units have been constructed in Nyanza, Kamonyi, Ruhango, Muhanga and Gisagara.

\section{Challenges}

- Insufficient financial resources and small amount of development partners in some Disticts (Ruhango, Gisagara, Nyanza, Huye);

- Some "Banque Populaire du Rwanda" sub-branches have gone slowly in delivering loans for Girinka Program;

- The lack or inexistence of data management information system in local government institutions;

- Changes in local government leadership (District executive committees) in Ruhango, Nyanza and Huye.

\section{PRIORITIES AND PLANS FOR July 2009- June 2010}

- $\quad$ Land use consolidation on 62706 Hectares for cassava, maize, Irish potatoes, tea, coffee, rice and wheat.

- Increase livestock and agriculture productivity in general and especially the productivity of export crops (coffee and tea);

- Implementation of JYAMBERE program : 4176 families will graduate from extreme poverty;

- Environment protection by insuring that $80 \%$ of riversides are protected and that the District Forest master plans are implemented;

- Public-private partnership promotion through investment companies;

- Financial facilities promotion by ensuring that in every Sector there is an operational SACCO, and an operational COOJAD in every District;

- To increase performance in customer care and service delivery;

- Security maintenance and fight against corruption and injustice as well as unity and reconciliation promotion;

- Monitoring and evaluation of the closing of Gacaca courts activities;

- Family planning, fighting malnutrition and HIV/AIDS, health care insurance and hygiene promotion;

- $\quad$ Nine years Basic education for all;

- Settlement in agglomeration sites;

- Industry promotion especially those related to the agro-business;

- Tourism promotion: studies and preparation of tourism sites. 


\begin{tabular}{|c|c|c|c|c|c|}
\hline $\begin{array}{l}\text { EDPRS strategic } \\
\text { outcomes }\end{array}$ & $\begin{array}{l}\text { Indicators for each policy } \\
\text { action }\end{array}$ & EDPRS policy action for Jan-Jun 2009 & $\mathbf{Y}$ & Progress and Challenges & $\begin{array}{l}\text { Actions taken to } \\
\text { overcome } \\
\text { challenges }\end{array}$ \\
\hline \multirow{5}{*}{$\begin{array}{l}1.1 \text { Prudent macro } \\
\text { economic } \\
\text { management } \\
\text { ensured }\end{array}$} & $\begin{array}{l}\text { Net domestic financing (as \% } \\
\text { of GDP) }\end{array}$ & $\begin{array}{l}\text { Finalize and implement } 2009 / 2010 \text { budget } \\
\text { in line with the EDPRS priorities and the } \\
\text { medium term macro framework }\end{array}$ & G & Submitted to the parliament & \\
\hline & $\begin{array}{l}\text { Inflation rate (core inflation, } \\
\text { annual \% change, end period } \\
\text { basis) }\end{array}$ & $\begin{array}{l}\text { BNR to use policy instruments: Reserve } \\
\text { requirement; Foreign exchange sales; and } \\
\text { Treasury bill sales to mop up excess } \\
\text { liquidity such that monetary policy targets } \\
\text { are achieved. }\end{array}$ & G & $\begin{array}{l}\text { Inflation is subsiding, domestic credit } \\
\text { situation is being addressed }\end{array}$ & \\
\hline & \multirow[t]{3}{*}{$\begin{array}{l}\text { Credit to private sector (as \% } \\
\text { of GDP) }\end{array}$} & Operationalize MF credit fund & G & MF credit fund operational & \\
\hline & & $\begin{array}{l}\text { Complete feasibility study of establishing } \\
\text { a rural micro-insurance company }\end{array}$ & Y & $\begin{array}{l}\text { Rural micro insurance products were } \\
\text { developed and tested with MINAGRI } \\
\text { and SONARWA on tomato growing } \\
\text { farmers }\end{array}$ & \\
\hline & & $\begin{array}{l}\text { Adopt appropriate legal and regulatory } \\
\text { framework for national payment systems, } \\
\text { credit bureau, and secured transactions. }\end{array}$ & G & $\begin{array}{l}\text { National payment systems: the strategy } \\
\text { was developed and National Council is } \\
\text { operational, }\end{array}$ & \\
\hline $\begin{array}{l}1.2 \quad \text { Enhanced } \\
\text { business climate }\end{array}$ & Index on business environment & $\begin{array}{l}\text { Operationalize Commercial Registration } \\
\text { Agency }\end{array}$ & G & $\begin{array}{l}\text { The activities of Rwanda Commercial } \\
\text { Registration Services Agency (RCRSA) } \\
\text { are on track }\end{array}$ & \\
\hline
\end{tabular}




\begin{tabular}{|c|c|c|c|c|c|}
\hline $\begin{array}{l}\text { EDPRS strategic } \\
\text { outcomes }\end{array}$ & $\begin{array}{l}\text { Indicators for each policy } \\
\text { action }\end{array}$ & EDPRS policy action for Jan-Jun 2009 & $\mathbf{Y}$ & Progress and Challenges & $\begin{array}{l}\text { Actions taken to } \\
\text { overcome } \\
\text { challenges }\end{array}$ \\
\hline & & & & $\begin{array}{l}\text { Three liaison offices have been } \\
\text { established (Muhanga, Rusizi and Huye). }\end{array}$ & \\
\hline & & $\begin{array}{l}\text { Effectively apply all modules of Asycuda } \\
\text { and reinforce valuation unit in customs }\end{array}$ & G & $\begin{array}{l}\text { All borders are connected to customs } \\
\text { ASYCUDA ++ Network except Rutete } \\
\text { which will be connected soon }\end{array}$ & \\
\hline & $\begin{array}{l}\text { Score of Investor Perceptions } \\
\text { of regulatory issues, licensing }\end{array}$ & $\begin{array}{l}\text { Implementation of the "quick wins" } \\
\text { reform }\end{array}$ & G & $\begin{array}{l}\text { Reform was done and a number of } \\
\text { licenses removed }\end{array}$ & \\
\hline & resolution & $\begin{array}{l}\text { Review all licenses, simplify and } \\
\text { streamline the most cumbersome ones to } \\
\text { reduce time and procedures taken to issue } \\
\text { licenses }\end{array}$ & G & $\begin{array}{l}8 \text { licenses identified and the BLRC } \\
\text { recommends streamlining them in order } \\
\text { to reduce the number of days and in a } \\
\text { few case the fee involved in obtaining } \\
\text { the licenses. } \\
\text { Those licenses are following: } \\
\text { 1. Transfer of Land Title; } \\
\text { 2. Tax Clearance Certificate } \\
\text { 3. Clearing Agent Certificate } \\
\text { 4. Driving License } \\
\text { 5. Road Worthiness Certificate } \\
\text { 6. Building Permit } \\
\text { 7. Import visa drugs and Import license } \\
\text { 8. Eor drugs } \\
\text { 8nvironmental Impact Assessment }\end{array}$ & \\
\hline & & $\begin{array}{l}\text { Conduct baseline survey on investor } \\
\text { perceptions }\end{array}$ & $\mathrm{G}$ & The survey was completed & \\
\hline & $\%$ of investment to GDP & Develop and Validate Industrial Policy & G & $\begin{array}{l}\text { It was completed and it is waiting to be } \\
\text { validated with Industrial Master Plan }\end{array}$ & \\
\hline Economic & of electricity & $\begin{array}{l}\text { Choose technico-economic technology for } \\
\text { rural electrification (Electrogaz \& }\end{array}$ & G & Cost efficient distribution Technology & \\
\hline
\end{tabular}




\begin{tabular}{|c|c|c|c|c|c|}
\hline $\begin{array}{l}\text { EDPRS strategic } \\
\text { outcomes }\end{array}$ & $\begin{array}{l}\text { Indicators for each policy } \\
\text { action }\end{array}$ & EDPRS policy action for Jan-Jun 2009 & $\mathbf{G}$ & Progress and Challenges & $\begin{array}{l}\text { Actions taken to } \\
\text { overcome } \\
\text { challenges }\end{array}$ \\
\hline \multirow[t]{8}{*}{ infrastructure built } & \multirow[t]{2}{*}{ subscriptions } & Mininfra) & & for rural Electrification has been selected & \\
\hline & & $\begin{array}{l}\text { Project Management Directorate for } \\
\text { implementation of the National Electricity } \\
\text { Rollout program established in Electrogaz } \\
\text { and operational }\end{array}$ & G & $\begin{array}{l}\text { The directorate is already setup and } \\
\text { recruitment is ongoing }\end{array}$ & \\
\hline & \multirow[t]{2}{*}{ MW of electricity installed } & $\begin{array}{l}\text { Diversify energy sources (methane gas, } \\
\text { hydro power \& solar Commission } 20 \mathrm{MW} \\
\text { Heavy Fuel Oil power plant) }\end{array}$ & G & $\begin{array}{l}\text { 2MW of Methane gas was produced to } \\
\text { the National grid, } 20 \mathrm{MW} \text { Jabana of } \\
\text { Heavy fuel was commissioned }\end{array}$ & \\
\hline & & $\begin{array}{l}\text { Sign contract between MININFRA and at } \\
\text { least } 1 \text { IPP for generation of electricity }\end{array}$ & G & $\begin{array}{l}\text { MININFRA signed Contract with } \\
\text { Contour Global in March } 2009\end{array}$ & \\
\hline & \multirow[t]{4}{*}{$\begin{array}{l}\% \text { of Classified National Road } \\
\text { network in good condition }\end{array}$} & $\begin{array}{l}\text { Commence and complete Rehabilitation } \\
\text { of at least } 20 \mathrm{~km} \text { of the } 271 \mathrm{~km} \text { of Paved } \\
\text { Roads }\end{array}$ & G & $20 \mathrm{Km}$ of paved road Completed & \\
\hline & & $\begin{array}{l}\text { Complete Periodic Maintenance of at least } \\
120 \mathrm{~km} \text { (cum) of the } 780 \mathrm{~km} \text { of National } \\
\text { Earth Roads }\end{array}$ & $\mathrm{G}$ & $\begin{array}{l}\text { More than } 90 \% \text { of expected completion } \\
\text { on the maintenance of the National Earth } \\
\text { roads was completed }\end{array}$ & \\
\hline & & $\begin{array}{l}\text { Establish Axle Load control system for } \\
50 \% \text { of the National Paved Road Network }\end{array}$ & $\mathbf{R}$ & $\begin{array}{l}\text { Inventory has not yet been carried out so } \\
\text { as to begin the work }\end{array}$ & \\
\hline & & $\begin{array}{l}\text { Commencement of Transport Master Plan } \\
\text { study }\end{array}$ & $\mathbf{Y}$ & Evaluation of bids ongoing & \\
\hline
\end{tabular}




\begin{tabular}{|c|c|c|c|c|c|}
\hline \multirow[t]{4}{*}{$\begin{array}{l}\text { EDPRS strategic } \\
\text { outcomes }\end{array}$} & \multirow[t]{3}{*}{$\begin{array}{l}\text { Indicators for each policy } \\
\text { action }\end{array}$} & EDPRS policy action for Jan-Jun 2009 & G & Progress and Challenges & $\begin{array}{l}\text { Actions taken to } \\
\text { overcome } \\
\text { challenges }\end{array}$ \\
\hline & & $\begin{array}{l}\text { Cabinet adoption of road sector reform } \\
\text { package covering an autonomous road } \\
\text { agency as part of the proposed Transport } \\
\text { Board, and Road Act }\end{array}$ & $\mathbf{G}$ & $\begin{array}{l}\text { Rwanda Transport Agency was adopted } \\
\text { by the Cabinet and now in the final } \\
\text { stages through the Parliament. }\end{array}$ & \\
\hline & & Adopt RMF Strategic Plan & $\mathrm{G}$ & The RMF Strategic Plan was adopted & \\
\hline & $\begin{array}{l}\% \text { of Classified District Road } \\
\text { network in good condition }\end{array}$ & $\begin{array}{l}\text { Districts sign Multi Annual ( } 3 \text { year) } \\
\text { Output and Performance Based Road } \\
\text { Contracts (OPBRC's) with at least } 1 \text { more } \\
\text { contractor }\end{array}$ & $\mathrm{R}$ & $\begin{array}{l}\text { The action was not implemented due to } \\
\text { concerns on capacity of Districts to } \\
\text { implement the program }\end{array}$ & \\
\hline \multirow[t]{4}{*}{$\begin{array}{l}1.5 \quad \text { increase } \\
\text { agricultural } \\
\text { productivity }\end{array}$} & \multirow[t]{2}{*}{$\begin{array}{ll}\text { Proportion } & \text { of arable land } \\
\text { sustainably } & \text { managed against } \\
\text { soil erosion } & \end{array}$} & $\begin{array}{l}\text { Feasibility studies for an additional } 14 \\
\text { sites identified under the LWH for } \\
\text { sustainable land and watershed } \\
\text { management are tendered, contracted and } \\
\text { initiated by MINAGRI. }\end{array}$ & $\mathrm{G}$ & $\begin{array}{l}\text { Feasibility studies for an additional } 17 \\
\text { sites identified under the LWH have } \\
\text { been contracted and initiated by } \\
\text { MINAGRI }\end{array}$ & \\
\hline & & $\begin{array}{l}\text { Publish Land consolidation ministerial } \\
\text { decree }\end{array}$ & $\mathrm{Y}$ & $\begin{array}{l}\text { The draft document was completed and } \\
\text { discussed with stakeholders; }\end{array}$ & \\
\hline & \multirow[t]{2}{*}{$\begin{array}{l}\text { Mineral Fertilizer consumption } \\
\text { (MT) }\end{array}$} & $\begin{array}{l}\text { Develop an action plan for private sector- } \\
\text { led fertilizer distribution based on key } \\
\text { lessons from 2009A. }\end{array}$ & $\mathrm{G}$ & $\begin{array}{l}\text { The fertilizer strategy is being } \\
\text { implemented; private sector is involved } \\
\text { in Agricultural inputs delivery and } \\
\text { distribution through the voucher system } \\
\text { for the fertilizer. Action plan for fertilizer } \\
\text { distribution available }\end{array}$ & \\
\hline & & $\begin{array}{l}\text { Action plan is endorsed by the Ministry } \\
\text { and shared with Rural Cluster }\end{array}$ & G & The action plan is available & \\
\hline
\end{tabular}




\begin{tabular}{|c|c|c|c|c|c|}
\hline \multirow[t]{7}{*}{$\begin{array}{l}\text { EDPRS strategic } \\
\text { outcomes }\end{array}$} & \multirow[t]{2}{*}{$\begin{array}{l}\text { Indicators for each policy } \\
\text { action }\end{array}$} & EDPRS policy action for Jan-Jun 2009 & G & Progress and Challenges & $\begin{array}{l}\text { Actions taken to } \\
\text { overcome } \\
\text { challenges }\end{array}$ \\
\hline & & $\begin{array}{l}\text { Extend fertilizer demonstration plot } \\
\text { program to include at least one per sector } \\
\text { in rural areas }\end{array}$ & G & $\begin{array}{l}\text { The fertilizer demonstration plot is being } \\
\text { implemented in the country }\end{array}$ & \\
\hline & \multirow[t]{3}{*}{$\begin{array}{l}\text { Production of key food } \\
\text { security crops }(1,000 \text { metric } \\
\text { tons cereal equivalent) }\end{array}$} & $\begin{array}{l}\text { Draft and endorse an agriculture } \\
\text { mechanisation strategy }\end{array}$ & G & $\begin{array}{l}\text { Agricultural mechanization strategy has } \\
\text { been developed and will be endorsed at } \\
\text { the next Rural Cluster meeting }\end{array}$ & \\
\hline & & $\begin{array}{l}\text { Adoption of seed policy and action plan } \\
\text { by cabinet }\end{array}$ & $\mathrm{G}$ & $\begin{array}{l}\text { The seed policy and action plan was } \\
\text { adopted by the cabinet in March } 2009\end{array}$ & \\
\hline & & $\begin{array}{l}\text { Draft, cost and validate the } 5 \text {-year action } \\
\text { plan to implement the Seed Policy. }\end{array}$ & G & $\begin{array}{l}\text { The Seed Action Plan has been costed } \\
\text { and validated }\end{array}$ & \\
\hline & \multirow[t]{2}{*}{$\begin{array}{l}\text { Percentage of livestock in } \\
\text { intensive systems }\end{array}$} & $\begin{array}{l}\text { Conduct an evaluation review of the } \\
\text { implementation of the One Cow per poor } \\
\text { household policy }\end{array}$ & G & $\begin{array}{l}\text { The evaluation review was done, } \\
\text { presented to cabinet and adopted }\end{array}$ & \\
\hline & & $\begin{array}{l}\text { Conduct a review of the implementation } \\
\text { of the improved animal husbandry and } \\
\text { zero grazing policy }\end{array}$ & $\mathrm{Y}$ & The review is ongoing & \\
\hline $\begin{array}{lr}1.6 & \text { Optimal } \\
\text { utilisation } & \text { of } \\
\text { natural resources }\end{array}$ & $\begin{array}{l}\text { 1.6.1 Percentage of national } \\
\text { forest cover }\end{array}$ & $\begin{array}{l}\text { Finalise and adopt National Forest plan, } \\
\text { forestry policy and forestry legislation } \\
\text { (MINIRENA and NAFA) }\end{array}$ & $\mathrm{G}$ & $\begin{array}{l}\text { Draft Forestry Policy and Law available } \\
\text { and ready to be submitted to Cabinet for } \\
\text { approval. } \\
\text { Twenty five District forest management } \\
\text { plans (DFMP) finalized. Four other } \\
\text { DFMP for Kicukiro, Gicumbi, Gatsibo, } \\
\text { Nyagatare, and Bugesera are at advanced } \\
\text { level. }\end{array}$ & \\
\hline
\end{tabular}




\begin{tabular}{|c|c|c|c|c|c|}
\hline \multirow[t]{6}{*}{$\begin{array}{l}\text { EDPRS strategic } \\
\text { outcomes }\end{array}$} & $\begin{array}{l}\text { Indicators for each policy } \\
\text { action }\end{array}$ & EDPRS policy action for Jan-Jun 2009 & $\begin{array}{l}\mathrm{G} \\
\mathbf{Y}\end{array}$ & Progress and Challenges & $\begin{array}{l}\text { Actions taken to } \\
\text { overcome } \\
\text { challenges }\end{array}$ \\
\hline & \multirow[t]{3}{*}{$\begin{array}{l}\text { 1.6.2 Percentage of area of } \\
\text { privately owned land held } \\
\text { under written title }\end{array}$} & $\begin{array}{l}\text { Production of orthophotos for } 75 \% \text { of the } \\
\text { country }\end{array}$ & $\mathrm{G}$ & $\begin{array}{l}70 \% \text { Orthophotos (soft and hard copies) } \\
\text { have been delivered. }\end{array}$ & \\
\hline & & $\begin{array}{l}\text { Completion assessment of existing } \\
\text { conditions in the country, marked by } \\
\text { submission of a report of survey }\end{array}$ & $\mathrm{G}$ & $\begin{array}{l}\text { A draft has been produced and being } \\
\text { consulted with stakeholders }\end{array}$ & \\
\hline & & $\begin{array}{l}\text { Finalise Ministerial Instructions for } \\
\text { condominium registration }\end{array}$ & $\mathrm{G}$ & $\begin{array}{l}\text { Draft condominium instructions were } \\
\text { approved by Cabinet in May } 2009\end{array}$ & \\
\hline & $\begin{array}{l}\text { 1.6.4 Total revenue from } \\
\text { exports of minerals products(in } \\
\text { millions USD) }\end{array}$ & $\begin{array}{l}\text { Appropriate policies and subsidiary } \\
\text { legislations put in place to manage the } \\
\text { mining sector }\end{array}$ & $\mathrm{G}$ & $\begin{array}{l}\text { Zero draft documents of mining decrees } \\
\text { available and translated into three official } \\
\text { languages; } \\
\text { Two Ministerial Instructions have been } \\
\text { developed and transmitted to the local } \\
\text { governments concerning the submission } \\
\text { of mining reports and the assessment of } \\
\text { applications for exploration and mining } \\
\text { permits }\end{array}$ & \\
\hline & $\begin{array}{l}\text { 1.6.5 Area of land protected to } \\
\text { maintain biological diversity } \\
\text { currently }\end{array}$ & $\begin{array}{l}\text { Rehabilitate critically degraded } \\
\text { ecosystems, repairing the banks of sebeya } \\
\text { and Nyaborongo rivers, the shores of } \\
\text { lake Kivu and Muhazi including side } \\
\text { basins of Rweru, Kamiranzovu, } \\
\text { Mugesera and Akagera }\end{array}$ & $\mathrm{G}$ & $\begin{array}{l}\text { Activities for the rehabilitation of the } \\
\text { shores and watershed of Nyabarongo } \\
\text { started in Nyamagabe and Nyanza } \\
\text { District. Rehabilitation activities in all } \\
\text { riparian Districts will be launched in July } \\
2009 \text {. } \\
\text { Rehabilitation activities of the shores of } \\
\text { Lake Muhazi launched on 2nd June } 2009\end{array}$ & \\
\hline
\end{tabular}




\begin{tabular}{|c|c|c|c|c|c|}
\hline \multirow[t]{2}{*}{$\begin{array}{l}\text { EDPRS strategic } \\
\text { outcomes }\end{array}$} & $\begin{array}{l}\text { Indicators for each policy } \\
\text { action }\end{array}$ & EDPRS policy action for Jan-Jun 2009 & $\mathbf{Y}$ & Progress and Challenges & \multirow[t]{2}{*}{$\begin{array}{l}\text { Actions taken to } \\
\text { overcome } \\
\text { challenges }\end{array}$} \\
\hline & & & & $\begin{array}{l}\text { Watershed management plans for } \\
\text { Rugezi, Kamiranzovu, Rweru-Mugesera } \\
\text { and Akagera validated on the 13th March } \\
09\end{array}$ & \\
\hline $\begin{array}{l}2.1 \quad \text { Enhanced } \\
\text { family planning }\end{array}$ & $\begin{array}{l}\text { Percentage of women aged } \\
(15-49) \quad \text { using modern } \\
\text { contraceptives; }\end{array}$ & $\begin{array}{l}\text { Promulgation of new tariffs establishing } \\
\text { free FP services; }\end{array}$ & G & $\begin{array}{l}\text { All public Health Facility provide free } \\
\text { family planning methods and services. } \\
\text { The framework for the provision FP } \\
\text { service was developed and distributed in } \\
\text { all Health Facilities }\end{array}$ & \\
\hline \multirow{4}{*}{$\begin{array}{l}2.2 \quad \text { Improved } \\
\text { health and nutrition } \\
\text { status }\end{array}$} & $\begin{array}{l}\text { Percentage of children fully } \\
\text { immunised }\end{array}$ & $\begin{array}{l}15 \% \text { of health centres do outreach } \\
\text { services for immunization }\end{array}$ & $\mathrm{G}$ & $\begin{array}{l}100 \% \text { of Health centers do outreach } \\
\text { services for immunization }\end{array}$ & \\
\hline & $\begin{array}{lcr}\begin{array}{l}\text { Percentgae } \\
\text { ch }\end{array} & \text { under five } \\
\text { children using } & \text { Insecticide } \\
\text { Treated } & \text { Long } & \text { Lasting } \\
\text { mosquito-nets } & \end{array}$ & $\begin{array}{l}\text { Conduct national campaign for free } \\
\text { mosquito nets for under five children, } \\
\text { pregnant woman and other vulnerable } \\
\text { groups (PLHIV, Old people, etc,) }\end{array}$ & $\mathrm{Y}$ & $\begin{array}{l}\text { Already } 80.000 \text { mosquito } \text { nets were } \\
\text { distributed for under five and pregnant } \\
\text { women for first quarter } 2009 \text {. } \\
\text { The National campaign for free } \\
\text { mosquito- nets is in tender process }\end{array}$ & \\
\hline & $\begin{array}{l}\text { Percentage of assisted births in } \\
\text { an accredited health facility }\end{array}$ & $\begin{array}{l}\text { Pilot in kind incentive for birth delivery in } \\
\text { health facility }\end{array}$ & $\mathrm{G}$ & $\begin{array}{l}6 \text { ambulances purchased this semester to } \\
\text { help pregnant women in emergency } \\
\text { cases }\end{array}$ & \\
\hline & $\begin{array}{l}\text { Utilization Rate of primary } \\
\text { health care services (all visits } \\
\text { at health centers, private } \\
\text { dispensaries and visits by } \\
\text { community health workers) }\end{array}$ & $\begin{array}{l}\text { Promulgate Ministerial decree on "mutual } \\
\text { ticket moderator "variable based on social } \\
\text { economic category }\end{array}$ & $\mathrm{G}$ & $\begin{array}{l}\text { The revised mutual policy based on } \\
\text { payment according to social economic } \\
\text { category has been developed pending } \\
\text { approval by Cabinet }\end{array}$ & \\
\hline
\end{tabular}




\begin{tabular}{|c|c|c|c|c|c|}
\hline $\begin{array}{l}\text { EDPRS strategic } \\
\text { outcomes }\end{array}$ & $\begin{array}{l}\text { Indicators for each policy } \\
\text { action }\end{array}$ & EDPRS policy action for Jan-Jun 2009 & $\begin{array}{l}\mathbf{G} \\
\mathbf{Y}\end{array}$ & Progress and Challenges & $\begin{array}{l}\text { Actions taken to } \\
\text { overcome } \\
\text { challenges }\end{array}$ \\
\hline \multirow[t]{2}{*}{$\begin{array}{lr}2.3 & \text { Strengthened } \\
\text { health } \quad \text { financing } \\
\text { and pro-poor } \\
\text { approaches }\end{array}$} & $\begin{array}{l}\text { Per capita allocation to PBF } \\
\text { for health facilities and } \\
\text { community health cooperatives }\end{array}$ & $\begin{array}{l}\text { Evaluation of District steering committees } \\
\text { conducted and descriptive report of } \\
\text { impact evaluation published }\end{array}$ & G & $\begin{array}{l}\text { The evaluation of District PBF steering } \\
\text { committees report was carried out this } \\
\text { first quarter } 2009 \text { through PBF }\end{array}$ & \\
\hline & $\begin{array}{llr}\text { Percentage } & \text { of } & \text { public } \\
\text { expenditure } & \text { on } & \text { health } \\
\text { (including domestic, } & \text { GBS and } \\
\text { SBS) } & \end{array}$ & $\begin{array}{l}\text { Health Financing Policy and Strategy } \\
\text { Published }\end{array}$ & Y & $\begin{array}{l}\text { The draft document of policy available, } \\
\text { but needs to be updated. Situational } \\
\text { Analysis on Health Financing already } \\
\text { done. The findings will help to finalize } \\
\text { the draft policy }\end{array}$ & \\
\hline \multirow{5}{*}{$\begin{array}{ll}2.4 & \text { Improved } \\
\text { Access to } \text { Safe } \\
\text { Drinking }\end{array}$} & \multirow{5}{*}{$\begin{array}{l}\text { Percentage of population with } \\
\text { access to clean drinking water } \\
\text { (within } 500 \text { meters in rural } \\
\text { areas \& } 200 \text { meters in urban } \\
\text { areas) }\end{array}$} & Continue to prepare 3 district water & $\mathrm{G}$ & Completed & \\
\hline & & resources master plans & & & \\
\hline & & $\begin{array}{l}\text { Construct } 490 \mathrm{~km} \text { new water supply } \\
\text { systems }\end{array}$ & G & $\begin{array}{l}402 \mathrm{~km} \text { constructed in addition to } 50 \\
\text { protected springs (serving } 12,500 \text { people) } \\
\text { in northern province }\end{array}$ & \\
\hline & & $\begin{array}{l}\text { Draft water supply and sanitation policy } \\
\text { in place and organize the workshops } \\
\text { (provincial and national level) for } \\
\text { discussion with all partners }\end{array}$ & $\mathrm{G}$ & $\begin{array}{l}\text { First copy was presented to stakeholders } \\
\text { pending finalization by the consultant }\end{array}$ & \\
\hline & & $\begin{array}{l}\text { Management Information System (MIS) } \\
\text { in place }\end{array}$ & G & $\begin{array}{l}\text { The MIS was completed but pending } \\
\text { housing of the software and organization } \\
\text { of training for the management staff }\end{array}$ & \\
\hline $\begin{array}{l}2.5 \quad \text { Improved } \\
\text { sanitation status }\end{array}$ & $\begin{array}{l}\text { Percentage of population with } \\
\text { access to hygienic sanitation } \\
\text { facilities }\end{array}$ & $\begin{array}{l}\text { One third of Sanitation facilities in pilot } \\
\text { sectors completed in each Province }\end{array}$ & $\mathrm{Y}$ & $\begin{array}{l}253 \text { completed in schools and facilities } \\
\text { constructed in Nyamagabe and } \\
\text { Nyaruguru in imidugudu }\end{array}$ & \\
\hline
\end{tabular}




\begin{tabular}{|c|c|c|c|c|c|}
\hline \multirow[t]{6}{*}{$\begin{array}{l}\text { EDPRS strategic } \\
\text { outcomes }\end{array}$} & \multirow[t]{6}{*}{$\begin{array}{l}\text { Indicators for each policy } \\
\text { action }\end{array}$} & EDPRS policy action for Jan-Jun 2009 & G & Progress and Challenges & $\begin{array}{l}\text { Actions taken to } \\
\text { overcome } \\
\text { challenges }\end{array}$ \\
\hline & & $\begin{array}{l}\text { Prepare the sanitation strategy as party of } \\
\text { the water and sanitation policy }\end{array}$ & G & $\begin{array}{l}\text { First draft of the Policy was discussed } \\
\text { with stakeholders }\end{array}$ & \\
\hline & & $\begin{array}{l}\text { Carry out an Inventory of the existing } \\
\text { technology in Rwanda }\end{array}$ & G & The inventory was completed & \\
\hline & & $\begin{array}{l}\text { Put in place the appropriated technologies } \\
\text { and disseminate in rural areas }\end{array}$ & $\bar{G}$ & The technology is already in place & \\
\hline & & $\begin{array}{l}\text { Carry out an Inventory of the towns } \\
\text { without sanitation master plans }\end{array}$ & G & The inventory completed & \\
\hline & & $\begin{array}{l}\text { Prepare a handbook on hygiene and } \\
\text { sanitation for teacher and handbook on } \\
\text { HAMS }\end{array}$ & $\mathrm{Y}$ & $\begin{array}{l}\text { Contract to produce the handbooks was } \\
\text { signed between the Ministry and a } \\
\text { consultant }\end{array}$ & \\
\hline \multirow{3}{*}{$\begin{array}{l}2.6 \text { Integrated and } \\
\text { sustainable } \\
\text { management of } \\
\text { water resources }\end{array}$} & \multirow{3}{*}{$\begin{array}{l}\text { Percentage of known water } \\
\text { resources/bodies checked for } \\
\text { quality and quantity }\end{array}$} & $\begin{array}{l}\text { Continue to improve water information } \\
\text { system }\end{array}$ & $\bar{G}$ & $\begin{array}{l}\text { Data from } 22 \text { limn metric stations are } \\
\text { collected and put in the date base }\end{array}$ & \\
\hline & & $\begin{array}{l}\text { Rehabilitate } 5 \text { hydrological and limn } \\
\text { metric stations }\end{array}$ & $\bar{Y}$ & $\begin{array}{l}\text { Tender documents for the rehabilitation } \\
\text { of } 14 \text { limn metric stations have been } \\
\text { completed }\end{array}$ & \\
\hline & & $\begin{array}{l}\text { Feasibility study to assess water resources } \\
\text { to facilitate investment for economic } \\
\text { production }\end{array}$ & G & $\begin{array}{l}17 \text { Sites were Identified and } 15 \text { of them } \\
\text { drilled and equipped with hand pumps in } \\
\text { districts: } 4 \text { in Nyamagabe, } 7 \text { in Nyanza } \\
\text { and } 4 \text { in Musanze }\end{array}$ & \\
\hline $\begin{array}{l}2.7 \quad \text { Enhanced } \\
\text { population skills }\end{array}$ & Primary school completion rate & Publish education quality standards & G & Approved by the cabinet & \\
\hline
\end{tabular}




\begin{tabular}{|c|c|c|c|c|c|}
\hline $\begin{array}{l}\text { EDPRS strategic } \\
\text { outcomes }\end{array}$ & $\begin{array}{l}\text { Indicators for each policy } \\
\text { action }\end{array}$ & EDPRS policy action for Jan-Jun 2009 & $\mathbf{Y}$ & Progress and Challenges & $\begin{array}{l}\text { Actions taken to } \\
\text { overcome } \\
\text { challenges }\end{array}$ \\
\hline & & $\begin{array}{l}\text { Adoption of a framework and procedures } \\
\text { for decentralised procurement and school- } \\
\text { level selection of text books }\end{array}$ & G & The Framework was adopted & \\
\hline & & $\begin{array}{l}\text { Issuance of an invitation to publishers for } \\
\text { the submission of proposals of teaching } \\
\text { and learning materials for inclusion in the } \\
\text { national approved list of such materials }\end{array}$ & $\mathrm{G}$ & $\begin{array}{l}\text { The material's list was approved by } \\
\text { steering committee }\end{array}$ & \\
\hline & $\begin{array}{l}\text { Primary school completion for } \\
\text { girls }\end{array}$ & Approve girls education policy & $\mathrm{G}$ & Approved by the Cabinet & \\
\hline & & $\begin{array}{l}\text { Finalise costed strategic plan for the } \\
\text { implementation of Girls' Education Policy }\end{array}$ & $\mathrm{G}$ & Finalized and waiting for validation & \\
\hline & $\begin{array}{l}\text { Primary school pupil to } \\
\text { qualified teacher ratio }\end{array}$ & $\begin{array}{l}\text { Adopted a costed Teacher Development } \\
\text { Management (TDM) strategic plan that } \\
\text { included coordination of INSET of } \\
\text { teachers }\end{array}$ & $\mathrm{Y}$ & $\begin{array}{l}\text { The consultant was hired and is } \\
\text { developing the document }\end{array}$ & \\
\hline & $\begin{array}{lcr}\text { Transition from } & \text { basic } \\
\text { education (TC) to upper } \\
\text { secondary education }\end{array}$ & $\begin{array}{l}\text { Carry out analytical work and studies on } \\
\text { post basic education as part of the country } \\
\text { status report }\end{array}$ & G & $\begin{array}{l}\text { The } 1^{\text {st }} \text { draft has been presented to } \\
\text { MINEDUC }\end{array}$ & \\
\hline & $\begin{array}{l}\text { Ratio of higher education } \\
\text { students enrolled in science } \\
\text { courses for girls }\end{array}$ & $\begin{array}{l}\text { Ensure approval of Special Needs } \\
\text { Education (SEN) policy }\end{array}$ & $\mathrm{G}$ & The policy was approved & \\
\hline $\begin{array}{lr}2.8 & \text { Improved } \\
\text { Social } & \text { Safety Net }\end{array}$ & $\begin{array}{l}\text { The percentage of households } \\
\text { in the bottom two categories of } \\
\text { extreme poverty according to }\end{array}$ & $\begin{array}{l}\text { Government has committed budget } \\
\text { allocations to implement the VUP } \\
\text { program in at least } 15 \text { pilot sectors and }\end{array}$ & $\mathrm{G}$ & $\begin{array}{l}\text { Government has committed budget to } \\
\text { implement in } 30 \text { pilot sectors. There is a } \\
\text { challenge of coordination. }\end{array}$ & $\begin{array}{l}\text { The action to } \\
\text { improve the } \\
\text { coordination }\end{array}$ \\
\hline
\end{tabular}




\begin{tabular}{|c|c|c|c|c|c|}
\hline $\begin{array}{l}\text { EDPRS strategic } \\
\text { outcomes }\end{array}$ & $\begin{array}{l}\text { Indicators for each policy } \\
\text { action }\end{array}$ & EDPRS policy action for Jan-Jun 2009 & G & Progress and Challenges & $\begin{array}{l}\text { Actions taken to } \\
\text { overcome } \\
\text { challenges }\end{array}$ \\
\hline & UBUDEHE classification & $\begin{array}{l}\text { ensured coordination of all social } \\
\text { protection activities, in accordance with } \\
\text { National Social Protection Policy }\end{array}$ & & & $\begin{array}{l}\text { include: working } \\
\text { with JADFs, } \\
\text { sector mapping, } \\
\text { coordinated } \\
\text { targeting, and } \\
\text { harmonized and } \\
\text { agreed } \\
\text { vulnerability and } \\
\text { poverty criteria }\end{array}$ \\
\hline & & Baseline survey to be conducted & $\mathrm{G}$ & $\begin{array}{l}\text { The study was completed and showed } \\
28.6 \% \text { in the bottom two categories of } \\
\text { poverty according to Ubudehe } \\
\text { classification }\end{array}$ & \\
\hline & $\begin{array}{l}\text { The percentage of eligible } \\
\text { households granted public } \\
\text { works }\end{array}$ & $\begin{array}{l}\text { Policy on public works applied in } \\
\text { accordance with international good } \\
\text { practice in respect of: wage rates (ratio to } \\
\text { market wage less than 1); community } \\
\text { selection of projects; voluntary savings } \\
\text { and direct payment of wages, and with } \\
\text { budget allocations reflecting EDPRS } \\
\text { priorities. }\end{array}$ & $\mathrm{G}$ & $\begin{array}{l}\text { Field visits indicate that in some sectors } \\
\text { the Public Work wage rate to market } \\
\text { wage rate ratio is equal to or more than } \\
1 . \\
\text { Projects are selected from the Sector } \\
\text { Development Plans. } \\
\text { Beneficiaries can decide whether to } \\
\text { retain a proportion of their public works } \\
\text { wages as savings in the bank } \\
\text { Beneficiaries are being paid directly (not } \\
\text { through contractors) }\end{array}$ & \\
\hline
\end{tabular}




\begin{tabular}{|c|c|c|c|c|c|}
\hline $\begin{array}{l}\text { EDPRS strategic } \\
\text { outcomes }\end{array}$ & $\begin{array}{l}\text { Indicators for each policy } \\
\text { action }\end{array}$ & EDPRS policy action for Jan-Jun 2009 & $\begin{array}{l}\mathbf{G} \\
\mathbf{Y}\end{array}$ & Progress and Challenges & $\begin{array}{l}\text { Actions taken to } \\
\text { overcome } \\
\text { challenges }\end{array}$ \\
\hline & $\begin{array}{l}\text { The percentage of eligible } \\
\text { households granted direct } \\
\text { support in VUP sector }\end{array}$ & $\begin{array}{l}\text { Policy of direct transfers applied in } \\
\text { accordance with international good } \\
\text { practice policies in respect of transparent } \\
\text { communication systems for determining } \\
\text { eligibility of clients and timely payment } \\
\text { of benefits, with budget allocations } \\
\text { reflecting EDPRS policy priorities }\end{array}$ & G & $\begin{array}{l}\text { The targeting process is transparent - } \\
\text { involving community members in } \\
\text { identification and validation of eligibility } \\
\text { lists } \\
\text { Payments have not yet been timely. } \\
\text { Start-up issues were encountered } \\
\text { concerning opening bank accounts and } \\
\text { delays in transmission of funds at } \\
\text { different levels }\end{array}$ & \\
\hline & $\begin{array}{l}\text { Number of vulnerable } \\
\text { households accessing credit } \\
\text { and savings facilities }\end{array}$ & $\begin{array}{l}\text { Policy of microfinance applied in } \\
\text { accordance with international good } \\
\text { practice policies }\end{array}$ & $\mathrm{Y}$ & $\begin{array}{l}\text { A microfinance consultant provided } \\
\text { recommendations on revisions to the } \\
\text { original financial services policy and } \\
\text { procedures manual, based on-going } \\
\text { developments in Rwanda and } \\
\text { international best practice } \\
\text { SACCOs are being established and/or } \\
\text { strengthened in VUP sectors, through } \\
\text { which vulnerable households will be able } \\
\text { to access credit }\end{array}$ & \\
\hline $\begin{array}{l}3.2 \text { Effective } \\
\text { coordination of } \\
\text { national labor force }\end{array}$ & $\begin{array}{l}\text { Number of new non-farm jobs } \\
\text { created (cumulative target) } \\
\text { (indicative) }\end{array}$ & $\begin{array}{l}\text { Implement program to take at least } 120 \\
\text { youth from universities on internship }\end{array}$ & $\mathrm{G}$ & $\begin{array}{l}456 \text { candidate applications were received } \\
\text { and } 100 \text { persons were maintained to } \\
\text { begin the Internship programs in July } \\
2009 \text {. On 24th June 2009, MIFOTRA } \\
\text { sent their names in different Institutions } \\
\text { (Public, Private Sector) to attend the } \\
\text { internship programs }\end{array}$ & $\begin{array}{l}\text { Sensitize all } \\
\text { partners to } \\
\text { finance the } \\
\text { internship } \\
\text { program }\end{array}$ \\
\hline
\end{tabular}




\begin{tabular}{|c|c|c|c|c|c|}
\hline \multirow[t]{4}{*}{$\begin{array}{l}\text { EDPRS strategic } \\
\text { outcomes }\end{array}$} & \multirow[t]{4}{*}{$\begin{array}{l}\text { Indicators for each policy } \\
\text { action }\end{array}$} & EDPRS policy action for Jan-Jun 2009 & $\begin{array}{l}\mathbf{G} \\
\mathbf{Y}\end{array}$ & Progress and Challenges & \multirow[t]{2}{*}{$\begin{array}{l}\text { Actions taken to } \\
\text { overcome } \\
\text { challenges }\end{array}$} \\
\hline & & Submit the labour code to Cabinet & G & $\begin{array}{l}\text { Labor Laws were approved by the } \\
\text { Parliament and published in the Official } \\
\text { Gazette on } 27^{\text {th }} \text { May } 2009\end{array}$ & \\
\hline & & $\begin{array}{l}\text { Strengthen district wide } 5 \text { Youth savings } \\
\& \text { credit schemes }\end{array}$ & $\mathrm{G}$ & $\begin{array}{l}\text { COOJAD has opened its offices in } 4 \\
\text { Districts ( Nyagatare, Rulindo, } \\
\text { Nyaruguru and Rubavu). They are still } \\
\text { waiting for approval from BNR \& } \\
\text { MINICOM to start giving loans. } \\
\text { COOJAD has } 2928 \text { members and } 163 \\
\text { loans were given in } 2009\end{array}$ & \\
\hline & & Operationalize 40 youth cooperatives & $\mathrm{G}$ & $\begin{array}{l}\text { The identification, selection \& support to } \\
\text { youth associations in the process of } \\
\text { transforming them into Cooperatives are } \\
\text { ongoing. } 36 \text { cooperatives have been } \\
\text { transformed }\end{array}$ & \\
\hline $\begin{array}{l}3.3 \quad \text { Enhanced } \\
\text { Local } \\
\text { Governments } \\
\text { Capacity }\end{array}$ & $\begin{array}{l}\text { Percentage of Districts which } \\
\text { achieve a minimum of } 80 \% \text { of } \\
\text { their service delivery and } \\
\text { sustainable local development } \\
\text { targets for which they are } \\
\text { responsible }\end{array}$ & $\begin{array}{l}\text { Adopt and operationalize comprehensive } \\
\text { 5-year capacity building strategy for } \\
\text { Local Governments }\end{array}$ & $x^{2}$ & $\begin{array}{l}\text { District capacity building plans are in } \\
\text { place, every year MINALOC develops } \\
\text { an action plan for the implementation of } \\
\text { these plans. } \\
\text { Variety of capacity building trainings for } \\
\text { community development committees } \\
\text { (CDC) and Tax Advisory councils } \\
\text { conducted } \\
\text { New local Administrative structure was } \\
\text { developed where staff numbers has } \\
\text { increased especially at sector ( } 5 \text { to } 9) \text { and } \\
\text { cell }(1 \text { to } 2) \text { levels }\end{array}$ & \\
\hline
\end{tabular}




\begin{tabular}{|c|c|c|c|c|c|}
\hline $\begin{array}{l}\text { EDPRS strategic } \\
\text { outcomes }\end{array}$ & $\begin{array}{l}\text { Indicators for each policy } \\
\text { action }\end{array}$ & EDPRS policy action for Jan-Jun 2009 & $\mathbf{Y}$ & Progress and Challenges & $\begin{array}{l}\text { Actions taken to } \\
\text { overcome } \\
\text { challenges }\end{array}$ \\
\hline \multirow{3}{*}{$\begin{array}{l}3.4 \quad \text { Enhanced } \\
\text { citizen } \\
\text { participation in } \\
\text { decision making }\end{array}$} & \multirow{3}{*}{$\begin{array}{l}\text { Percentage of citizens who feel } \\
\text { that they participate actively in } \\
\text { local decision making and that } \\
\text { local government is listening to } \\
\text { and addressing their priority } \\
\text { concerns. }\end{array}$} & $\begin{array}{l}\text { Develop sensitisation and mobilisation } \\
\text { strategy to promote citizens' awareness } \\
\text { and participation. }\end{array}$ & G & $\begin{array}{l}\text { Community forum established at cell } \\
\text { level (Inteko ya Rubanda). }\end{array}$ & \\
\hline & & $\begin{array}{l}\text { Ensure } 100 \text { people pass through Itorero in } \\
\text { each of } 3500 \text { Imidugudu, } 2000 \text { public } \\
\text { servants, } 1000 \text { university graduates }\end{array}$ & Y & $\begin{array}{l}600 \text { OCIR Coffee are undergoing } \\
\text { through Itorero training, } \\
61,000 \text { Health councilors from } \\
\text { MINISANTE and } 1200 \text { Agriculture \& } \\
\text { livestock extension workers from } \\
\text { MINAGRI members are going through } \\
\text { Itorero. }\end{array}$ & $\begin{array}{l}\text { Need to revise } \\
\text { the targets }\end{array}$ \\
\hline & & $\begin{array}{l}\text { Conduct research on social cohesion and } \\
\text { relationship status between released } \\
\text { suspects of genocide and genocide } \\
\text { surviving victims }\end{array}$ & G & $\begin{array}{l}\text { A study called Reconciliation Barometer } \\
\text { is being carried out. }\end{array}$ & \\
\hline \multirow{4}{*}{$\begin{array}{l}3.5 \quad \text { Improved } \\
\text { public } \\
\text { accountability }\end{array}$} & \multirow[t]{3}{*}{$\begin{array}{l}\text { Percentage of Performing } \\
\text { Budget Agencies }\end{array}$} & Develop a capacity building plan & G & $\begin{array}{l}1^{\text {st }} \text { draft developed, is waiting for } \\
\text { validation }\end{array}$ & \\
\hline & & $\begin{array}{l}\text { Conduct a baseline study on service } \\
\text { delivery }\end{array}$ & G & $\begin{array}{l}1^{\text {st }} \text { draft developed, is waiting for } \\
\text { validation }\end{array}$ & \\
\hline & & $\begin{array}{l}\text { MIFOTRA agrees with all central } \\
\text { ministries on staffing levels and } \\
\text { ministerial structures for optimal } \\
\text { performance within fiscal limits }\end{array}$ & $\mathrm{Y}$ & Staffing levels draft available & \\
\hline & $\begin{array}{l}\text { Percentage of corruption cases } \\
\text { processed by the prosecution }\end{array}$ & $\begin{array}{l}\text { Popularize laws on corruption and } \\
\text { accountability }\end{array}$ & $\mathrm{G}$ & $\begin{array}{l}\text { Sensitization has been done through } \\
\text { radio and TV shows and written press }\end{array}$ & \\
\hline
\end{tabular}




\begin{tabular}{|c|c|c|c|c|c|}
\hline \multirow[t]{4}{*}{$\begin{array}{l}\text { EDPRS strategic } \\
\text { outcomes }\end{array}$} & $\begin{array}{l}\text { Indicators for each policy } \\
\text { action }\end{array}$ & EDPRS policy action for Jan-Jun 2009 & $\mathbf{Y}$ & Progress and Challenges & $\begin{array}{l}\text { Actions taken to } \\
\text { overcome } \\
\text { challenges }\end{array}$ \\
\hline & & & & $\begin{array}{l}2 \text { press conferences have been organized } \\
\text { on the fight against corruption }\end{array}$ & \\
\hline & & $\begin{array}{l}\text { Effective application of legal instruments } \\
\text { on anti corruption; Accelerate the } \\
\text { procedures of pursuits and penalties of the } \\
\text { authors of corruption }\end{array}$ & $\mathrm{G}$ & $\begin{array}{l}\text { The high level meetings were organized } \\
\text { between NPPA, RNP, MINIJUST, and } \\
\text { Office of the Ombudsman to exchange } \\
\text { ideas on strategies to fight economic and } \\
\text { financial crime and the sensitization of } \\
\text { the public on their civic rights. }\end{array}$ & \\
\hline & & $\begin{array}{l}\text { Put in place the organic frame of NPPA } \\
\text { and a specialized unit pursuing economic } \\
\text { and financial crimes }\end{array}$ & $\mathrm{G}$ & $\begin{array}{l}\text { The specialized unit is operational and } \\
\text { investigates files of corruption and } \\
\text { embezzlement reported by the Auditor } \\
\text { General of Finance }\end{array}$ & \\
\hline \multirow{5}{*}{$\begin{array}{lr}3.6 & \text { Improved } \\
\text { access } & \text { to quality } \\
\text { justice } & \end{array}$} & \multirow{3}{*}{$\begin{array}{l}\text { Number of cases processed by } \\
\text { the courts in civil, penal (excl. } \\
\text { Genocide), and commercial } \\
\text { cases }\end{array}$} & Carry out justice sector needs assessment. & $\mathrm{Y}$ & The procurement process is ongoing & \\
\hline & & $\begin{array}{l}\text { Reinforce Justice sector technical } \\
\text { committees at District level through } \\
\text { capacity building. }\end{array}$ & $\mathrm{Y}$ & $\begin{array}{l}\text { The preparation of a Prime Minister's } \\
\text { Order to legally establish the District } \\
\text { Technical Committees is being finalized }\end{array}$ & \\
\hline & & $\begin{array}{l}\text { Establish bureaux of justice (MAJ) in } 6 \\
\text { districts }\end{array}$ & $\mathrm{G}$ & $\begin{array}{l}10 \text { districts were identified and } 6 \text { MAJ } \\
\text { operational }\end{array}$ & \\
\hline & \multirow[t]{2}{*}{$\begin{array}{l}\text { Percentage of Prisoners } \\
\text { relevant to actual Jail Capacity }\end{array}$} & Continue expansion of Butare prison & $\mathrm{G}$ & $\begin{array}{l}\text { Installation of biogas and water were } \\
\text { done at } 50 \% \text {. Tender for the construction } \\
\text { of toilets and completion of the outer } \\
\text { fence has been awarded. }\end{array}$ & \\
\hline & & Begin construction of Butamwa prison & $\mathrm{Y}$ & $\begin{array}{l}\text { The procurement process has begun at } \\
\text { District level. The expropriation exercise } \\
\text { is now done at } 70 \% \text { and construction will }\end{array}$ & $\begin{array}{l}\text { Speed up the } \\
\text { process in } \\
\text { partnership with }\end{array}$ \\
\hline
\end{tabular}




\begin{tabular}{|c|c|c|c|c|c|}
\hline \multirow[t]{7}{*}{$\begin{array}{l}\text { EDPRS strategic } \\
\text { outcomes }\end{array}$} & \multirow[t]{3}{*}{$\begin{array}{l}\text { Indicators for each policy } \\
\text { action }\end{array}$} & EDPRS policy action for Jan-Jun 2009 & G & Progress and Challenges & $\begin{array}{l}\text { Actions taken to } \\
\text { overcome } \\
\text { challenges }\end{array}$ \\
\hline & & & & start immediately after the completion. & $\begin{array}{l}\text { Nyarugenge } \\
\text { District }\end{array}$ \\
\hline & & $\begin{array}{l}\text { Acceleration of TIG activities and } \\
\text { Speeding up of judgement execution }\end{array}$ & $\bar{G}$ & $\begin{array}{l}58 \text { operational TIG work camps with a } \\
\text { total of } 23.580 \text { convicts undergoing their } \\
\text { sentence } \\
\text { Sensitization and civic education } \\
\text { programs; empowering TIG }\end{array}$ & \\
\hline & \multirow[t]{4}{*}{$\begin{array}{l}\text { Proportion of Resolved Human } \\
\text { Rights cases }\end{array}$} & $\begin{array}{l}\text { At least } 2 \text { cooperatives for Handicapped } \\
\text { persons are trained on human rights }\end{array}$ & $\mathrm{Y}$ & $\begin{array}{l}\text { Members of one cooperative have been } \\
\text { trained }\end{array}$ & \\
\hline & & $\begin{array}{l}\text { Members of the National Women Council } \\
\text { (Conseil national des Femmes) at national } \\
\text { level are trained on Human rights }\end{array}$ & G & $\begin{array}{l}\text { The following were trained: } \\
-1.114 \text { historically marginalized } \\
-29 \text { people live with AIDS/HIV } \\
\text {-60 Pastor for EER church for SHYIRA } \\
\text { Diocese } \\
\text {-167 prison guards }\end{array}$ & \\
\hline & & $\begin{array}{l}\text { Members of youth organizations are } \\
\text { trained at sector and district level. }\end{array}$ & $\mathrm{G}$ & $\begin{array}{l}-42,223 \text { beneficiaries in different schools } \\
\text { and during "ingando". }\end{array}$ & \\
\hline & & $\begin{array}{l}\text { Received complaints are addressed and } \\
\text { victims of violations of Human Rights are } \\
\text { restored their rights }\end{array}$ & $\mathrm{G}$ & $\begin{array}{l}771 \text { complaints were examined added to } \\
439 \text { which remained pending by the end } \\
\text { of the year } 2008 \text {. } \\
349 \text { complaints have been settled } \\
58 \text { were forwarded to the authorities } \\
\text { having the responsibility to solve them } \\
\text { and the commission continues to closely }\end{array}$ & \\
\hline
\end{tabular}




\begin{tabular}{|c|c|c|c|c|c|}
\hline \multirow[t]{3}{*}{$\begin{array}{l}\text { EDPRS strategic } \\
\text { outcomes }\end{array}$} & \multirow[t]{3}{*}{$\begin{array}{l}\text { Indicators for each policy } \\
\text { action }\end{array}$} & EDPRS policy action for Jan-Jun 2009 & \multirow[t]{2}{*}{ G } & \multirow{2}{*}{$\begin{array}{l}\text { Progress and Challenges } \\
\text { follow up their settlement }\end{array}$} & \multirow[t]{2}{*}{$\begin{array}{l}\text { Actions taken to } \\
\text { overcome } \\
\text { challenges }\end{array}$} \\
\hline & & & & & \\
\hline & & $\begin{array}{l}\text { Authors of Human Rights Violations' are } \\
\text { brought to Justice }\end{array}$ & $\mathrm{G}$ & $\begin{array}{l}721 \text { complaints are still under } \\
\text { investigation; } \\
74 \text { have been rejected } \\
8 \text { have been settled by other institutions } \\
\text { and the commission get a copy for them } \\
\text { NHRC is waiting for Prime Ministerial } \\
\text { order which allows it to proceed cases } \\
\text { into courts }\end{array}$ & $\begin{array}{l}\text { Legal documents } \\
\text { are available now }\end{array}$ \\
\hline \multirow[t]{3}{*}{$\begin{array}{lr}3.8 & \text { Enhanced } \\
\text { public } & \text { financial } \\
\text { management }\end{array}$} & \multirow[t]{3}{*}{$\begin{array}{l}\text { Index for multiyear perspective } \\
\text { in fiscal planning, expenditure } \\
\text { policy and budgeting }\end{array}$} & $\begin{array}{l}\text { Introduce and mainstream gender } \\
\text { budgeting }\end{array}$ & G & $\begin{array}{l}\text { Gender Based Budgeting was introduced } \\
\text { at beginning of } 2009 \text {. } \\
\text { However more stakeholders need to be } \\
\text { sensitized so that gender based budgeting } \\
\text { can be institutionalized. }\end{array}$ & $\begin{array}{l}\text { More } \\
\text { sensitization and } \\
\text { training } \\
\text { workshops are } \\
\text { envisaged in the } \\
\text { coming fiscal } \\
\text { year. }\end{array}$ \\
\hline & & Align budget calendar to EAC practices & G & $\begin{array}{l}\text { The national budget has been aligned } \\
\text { with the rest of the EAC as the first } \\
\text { budget for } 2009 / 2010 \text { was read on June } \\
11,2009 \text {. This trend will be maintained. }\end{array}$ & \\
\hline & & $\begin{array}{l}\text { Debt management strategy approved by } \\
\text { Cabinet }\end{array}$ & G & $\begin{array}{l}\text { The Debt Management Strategy was } \\
\text { completed towards the end of } 2008 \text {, and } \\
\text { has been adopted which GoR will adhere }\end{array}$ & \\
\hline
\end{tabular}




\begin{tabular}{|c|c|c|c|c|c|}
\hline \multirow[t]{5}{*}{$\begin{array}{l}\text { EDPRS strategic } \\
\text { outcomes }\end{array}$} & \multirow[t]{2}{*}{$\begin{array}{l}\text { Indicators for each policy } \\
\text { action }\end{array}$} & EDPRS policy action for Jan-Jun 2009 & $\mathbf{Y}$ & Progress and Challenges & \multirow[t]{2}{*}{$\begin{array}{l}\text { Actions taken to } \\
\text { overcome } \\
\text { challenges }\end{array}$} \\
\hline & & & & $\begin{array}{l}\text { to. } \\
\text { A debt manual is currently being drafted } \\
\text { that will help in the translation of the } \\
\text { strategy into operation. }\end{array}$ & \\
\hline & $\begin{array}{l}\text { Index of effectiveness of } \\
\text { payroll controls }\end{array}$ & $\begin{array}{l}\text { Carry out Data Cleaning from Legacy } \\
\text { Systems and Migrate to IPPIS Database. }\end{array}$ & G & $\begin{array}{l}\text { IPPIS Pay roll component has been } \\
\text { tested and It's now operational. The } \\
\text { salaries of the Central Government, } \\
\text { Judiciary and Legislature are now being } \\
\text { paid using the IPPIS since February } \\
2009 .\end{array}$ & $\begin{array}{l}\text { The HR module } \\
\text { is still under } \\
\text { development. } \\
\text { Until this is } \\
\text { completed, then } \\
\text { data can be easily } \\
\text { transferred to } \\
\text { IPPS from legacy }\end{array}$ \\
\hline & \multirow[t]{2}{*}{$\begin{array}{l}\text { Index on quality and timeliness } \\
\text { of annual financial statements }\end{array}$} & $\begin{array}{l}\text { Conduct training for short term skills } \\
\text { enhancement course and ACCA part } 1\end{array}$ & G & $\begin{array}{l}\text { Capacity building is on course being } \\
\text { provided by PwC through on-job } \\
\text { training, and ACCA training was re- } \\
\text { launched in } 2008 \text { and is being provided } \\
\text { by the Government. }\end{array}$ & \\
\hline & & Test Public Books and roll it on pilot basis & $\mathrm{Y}$ & $\begin{array}{l}\text { [Quality Assurance Group] was put in } \\
\text { place [with the help of the World Bank] } \\
\text { and has completed the first mission of an } \\
\text { independent quality assessment of the } \\
\text { development of IFMS in April } 2009 \text {. } \\
\text { This team recommended among other } \\
\text { things that the testing and piloting be } \\
\text { extended for an additional one year }\end{array}$ & $\begin{array}{l}\text { A revised } \\
\text { SmartFMS } \\
\text { implementation } \\
\text { plan has been } \\
\text { developed that } \\
\text { takes in to } \\
\text { consideration the } \\
\text { recommendations } \\
\text { of the Quality } \\
\text { Assurance }\end{array}$ \\
\hline
\end{tabular}




\begin{tabular}{|c|c|c|c|c|c|}
\hline $\begin{array}{l}\text { EDPRS strategic } \\
\text { outcomes }\end{array}$ & $\begin{array}{l}\text { Indicators for each policy } \\
\text { action }\end{array}$ & EDPRS policy action for Jan-Jun 2009 & $\mathbf{Y}$ & Progress and Challenges & $\begin{array}{l}\text { Actions taken to } \\
\text { overcome } \\
\text { challenges }\end{array}$ \\
\hline & & & & & Group. \\
\hline & & $\begin{array}{l}\text { Each Budget Agency submits a Fund } \\
\text { Accountability Statements for the FY2007 }\end{array}$ & 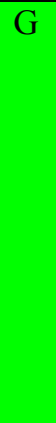 & $\begin{array}{l}\text { With the assistance of PwC, GoR } \\
\text { developed a financial reporting template } \\
\text { [FRT] that is used by all Budget } \\
\text { Agencies when preparing yearend } \\
\text { financial statements. According to the } \\
\text { Auditor General's report for the year } \\
\text { ended } 31 \text { December } 2007 \text { issued in } 2009 \text {, } \\
\text { only fourteen institutions did not submit } \\
\text { financial statements for the year } 2007 \text {. }\end{array}$ & \\
\hline & $\begin{array}{l}\text { Percentage of Internal audit } \\
\text { reports submitted }\end{array}$ & $\begin{array}{l}\text { Adopt and publish internal audit manuals } \\
\text { and internal auditors code of ethics }\end{array}$ & . & $\begin{array}{l}\text { An Internal Audit Charter was adopted } \\
\text { and published in the website in } 2008 \text {. } \\
\text { The Charter also has a code of ethics for } \\
\text { the internal audit staff. In } 2008 \text {, a total of } \\
88 \text { Internal Audit Reports were produced } \\
\text { [CG - } 66 \text { + LGs- } 22 \text { ] representing about } \\
30 \% \text { of budget agencies; this was an } \\
\text { improvement over the previous year. }\end{array}$ & \\
\hline & $\begin{array}{l}\text { Percentage of Government } \\
\text { expenditure audited by OAG }\end{array}$ & Install improved audit software & Y & $\begin{array}{l}\text { The OAG is still carrying out } \\
\text { comparisons of the different audit } \\
\text { software's used by various Supreme } \\
\text { Audit Institutions. }\end{array}$ & $\begin{array}{l}\text { The process will } \\
\text { be completed in } \\
\text { September } 2009 \\
\text { and appropriate } \\
\text { software can be } \\
\text { procured } \\
\text { thereafter. }\end{array}$ \\
\hline
\end{tabular}




\begin{tabular}{|c|c|c|c|c|c|}
\hline $\begin{array}{l}\text { EDPRS strategic } \\
\text { outcomes }\end{array}$ & $\begin{array}{l}\text { Indicators for each policy } \\
\text { action }\end{array}$ & EDPRS policy action for Jan-Jun 2009 & $\mathbf{G}$ & Progress and Challenges & $\begin{array}{l}\text { Actions taken to } \\
\text { overcome } \\
\text { challenges }\end{array}$ \\
\hline & $\begin{array}{l}\text { Percentage of Public enterprise } \\
\text { submitting fiscal reports }\end{array}$ & $\begin{array}{l}\text { Analyze and compile reports on fiscal } \\
\text { risks posed by GBEs }\end{array}$ & Y & $\begin{array}{l}\text { Analysis still being made though more } \\
\text { staff is needed to conclude this activity. }\end{array}$ & $\begin{array}{l}\text { The new } \\
\text { government } \\
\text { restructuring has } \\
\text { provided for a } \\
\text { full fledged unit } \\
\text { to deal with } \\
\text { public enterprises }\end{array}$ \\
\hline & $\begin{array}{l}\text { Proportion of the value of } \\
\text { procurement tendered } \\
\text { competitively or justified }\end{array}$ & $\begin{array}{l}\text { Conclude partnership agreement with } \\
\text { learning institution in Kigali to develop } \\
\text { curricula to provide basic training in } \\
\text { procurement }\end{array}$ & $\mathrm{Y}$ & $\begin{array}{l}\text { A memorandum of Understanding } \\
\text { between RPPA and RIAM but due to } \\
\text { lack of funding, the curricular has not } \\
\text { been developed }\end{array}$ & $\begin{array}{l}\text { To be funded in } \\
\text { the } 2010 / 11 \\
\text { Budget }\end{array}$ \\
\hline
\end{tabular}




\section{REPUBLIC OF RWANDA}

MINISTRY OF FINANCE AND ECONOMIC PLANNING

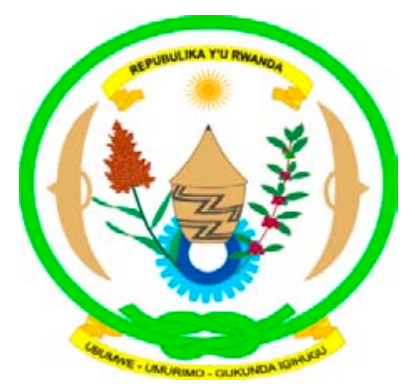

\section{ANNUAL REPORT ON THE IMPLEMENTATION OF THE ECONOMIC DEVELOPMENT AND POVERTY REDUCTION STRATEGY (EDPRS) \\ JULY 2009-JUNE 2010}




\section{Table of Contents}

LIST OF ABBREVIATIONS

Executive summary

1. Introduction

2. Economic Cluster $\underline{171}$

2.1. Macro Economic and Financial Sector $\underline{171}$

2.2. Private sector $\underline{173}$

2.3.Infrastructure sector. 175

2.3.1 Energy sub sector $\underline{175}$

2.3.2 Transport sub sector $\underline{176}$

2.3.3 ICT and Science, Technology and Innovation sub sector $\underline{178}$

2.4. Agriculture sector $\underline{178}$

2.5. Environment and natural resources Sector......................................... 180 3.Social Cluster $\underline{183}$

3.1 Health sector $\underline{183}$

3.2. Water and Sanitation Sector ......................................................... 185

3.3.Education sector ……………………………….......................... 186

3.4 Social Protection Sector ………………………............................ 188

3.5 Youth Sector .................................................................................. 189

4.Governance Cluster.............................................................................................................................190

4.1 Capacity Building and Employment Promotion Sector.............................191

4.2.Decentralization, Citizen Participation, Empowerment, Transparency and Accountability (DCPETA) Sector 
4.3.Justice, Reconciliation, Law and Order sector ................................... 194

4.4. Public Finance Management (PFM) Sector ........................................ 197

5. DISTRICT IMIHIGO EVALUATION FOR 2009/10 ......................................199

5.1.KEY ACHIEVEMENTS REALIZED BY DISTRICTS ..................... 200

5.3.CHALLENGES/LESSONS LEARNT ............................................ 201

5.4. THE WAY FORWARD …......................................................... 201

5.4.1.Quality Assurance Team............................................................................................ 201

5.4.2. Link between Imihigo and development strategies such as EDPRS,

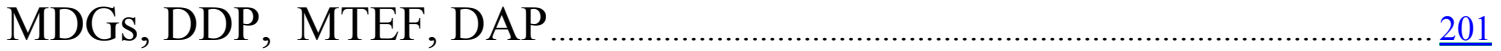

6. Integration of Cross-cutting issues:........................................................................ 202

6.1. Concerning Gender ................................................................... 202

6.2. Regarding Social inclusion .......................................................... 203

6.3. In relation to HIV/AIDS................................................................... 204

6.4. Regarding Environment and climate change .................................. 204

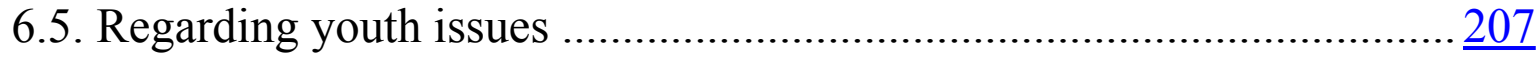

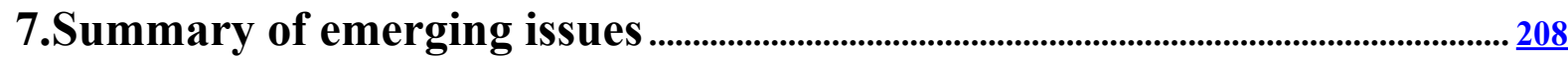

Annex: Detailed EDPRS Result and Policy Matrix (RPM) July 2009 -June 10211 


\section{List of Abbreviations}

AIDS: Acquired Immunodeficiency Syndrome

AWP: Annual Work Plans

BNR: National Bank of Rwanda

BSHG: Budget Support Harmonization Group

C.E.O: Chief Executive Officer

CBEP: Capacity Building and Employment Promotion

CCI: Cross Cutting Issues

CHW: Clinical Health Worker

CIP: Crop Intensification Group

CNLS: National Commission for the Fight against AIDS

COOJAD: Cooperative Bank for Youth Self Employment and development

CPAF: Common Performance Assessment Framework

DCPETA: Decentralization, Citizen Participation, Empowerment, Transparency and Accountability

DIP: Decentralization Implementation Plan

DPAF: Development Partners Assessment Framework

DPCG: Development Partners Coordination Group

DPM: Development Partners Meeting

EAC: East African Community

EDPRS: Economic Development and Poverty Reduction Strategy

EIA: Environment Impact Assessment

EMIS: Education Management Information System

ENR: Environment and Natural Resources

GBE: Government Business Entities

GDP: Gross Domestic Product

GoR: Government of Rwanda

Ha: Hectare

HACCP: Hazard Analysis and Critical Control Points

HIMO: High intensive Labor Community Works

HIV: Human Immunodeficiency Virus

HLI: Higher Learning Institutions

HMIS: health management information system

HR: Human Resource

HSSP: Health Sector Strategic Plan

ICT: Information and Communication Technology

INSET: In-Service Training Centers

IPPIS: Integrated Personnel and Payroll Information System

JAWP: Joint Annual Work Plan

JGA: Joint Governance Assessment

JHSR: Joint Health Sector Review

JRLO: Justice Reconciliation Law and Order

JSR: Joint Sector Review

LLITN: Long Lasting Insecticide Treated Nets

LTRP: Land Tenure Regularization Program

MDGS: Millennium Development Goals

MTEF: Medium Term Expenditure Framework

OAG: Office of the Auditor General

OPBRC: Output and Performance Based Road Contracts

PBF: Performance based financing

PFM: Public Finance Management

PMTCT: Prevention of Mother to Child Transmission

PPP: Public Private Partnership

PW: Public Works

RWF: Rwandan Francs

SGBV: Sexual and Gender Based Violence 
SME: small and medium enterprise

STD: Sexually Transmitted Diseases

SWAP: Sector Wide Approach

TC: Tronc Commun/ Ordinary level secondary

TVET: Technical Vocational Education and Training

UBPR: Union of Popular Bank in Rwanda

VCT: Volunteer Counseling and Testing

VUP: Vision 2020 Umurenge Program

WSS: Water Supply System

YFC: Youth Friendly Centers 


\section{Executive Summary}

2009/2010 is the third financial year in the implementation of the Economic Development and Poverty Reduction Strategy (EDPRS)- a strategy that provides a medium-term framework for achieving the country's long term development goals and aspirations as embodied in Rwanda Vision 2020, the seven year Government of Rwanda (GoR) programme, and the Millennium Development Goals.

This report assesses progress made in 2009/10 in implementation of the Economic Development and Poverty Reduction Strategy (EDPRS) based on the selected targets and policy actions defined in the EDPRS Results and Policy. It is organized in 3 clusters namely the Economic, Social and Governance clusters. Clusters implement strategic objectives as stated in the EDPRS Results and Policy Matrix:

$\begin{array}{lll}\text { S/N } & \text { EDPRS Strategic Objective (Results) } & \text { Cluster } \\ 1 & \text { Increased GDP Growth } & \text { Economic } \\ 2 & \begin{array}{l}\text { Managing population growth rate and enhancing } \\ \text { population development }\end{array} & \text { Social } \\ 3 & \begin{array}{l}\text { Enhanced gains through good governance } \\ \text { Governance }\end{array}\end{array}$

Under each strategic objective in the matrix, there are a number of strategic outcomes, associated indicators and targets as well as policy actions required to achieve them. Each EDPRS sector contributes to the implementation of one or more strategic outcomes and indicators/targets, through its fulfilling of agreed policy actions.

This implementation report is drawn from reports provided by each sector after the completion of a Sector Performance Report..

Overall, out of $\mathbf{6 3}$ targets that were assessed, 54 (86\%) were fully achieved or exceeded (G), 7 $(11 \%)$ were partially achieved $(\mathbf{Y})$, and for $\mathbf{2}(3 \%)$ we were significantly lagging behind(R). 10 outcomes were not due for assessment this year as they depend on ongoing surveys.

A total of $\mathbf{1 2 4}$ policy actions were planned for 2009/10. Out of these, a total of $\mathbf{8 7}$ policy actions $\mathbf{7 0 \%}$ ) were completed, 28 policy actions (23\%) were partially achieved and for 9 policy actions $\mathbf{7 \%}$ ) progress was not sufficient. . Summary by cluster is shown in the tables below: 
Table showing 2009/10 targets implementation status

\begin{tabular}{|l|l|r|r|r|r|}
\hline Cluster & \multicolumn{1}{l|}{ Green } & \multicolumn{1}{l|}{ Yellow } & \multicolumn{1}{l|}{ Red } & Total & \multicolumn{1}{l|}{ N/A } \\
\hline Economic & 25 & 3 & 0 & $\mathbf{2 8}$ & 1 \\
\hline Social & 17 & 1 & 0 & $\mathbf{1 8}$ & 7 \\
\hline Governance & 12 & 3 & 2 & $\mathbf{1 7}$ & 2 \\
\hline Total & $\mathbf{5 4}(\mathbf{8 6} \%)$ & $\mathbf{7 ( 1 1 \% )}$ & $\mathbf{2 ( 3 \% )}$ & $\mathbf{6 3}$ & $\mathbf{1 0}$ \\
\hline
\end{tabular}

Table showing 2009/10 policy actions implementation status

\begin{tabular}{|l|l|l|l|l|}
\hline Cluster & Green & Yellow & Red & Total \\
\hline Economic & 30 & 11 & 0 & $\mathbf{4 1}$ \\
\hline Social & 32 & 7 & 4 & $\mathbf{4 3}$ \\
\hline Governance & 25 & 10 & 5 & $\mathbf{4 0}$ \\
\hline Overall total & $\mathbf{8 7 ( 7 0 \% )}$ & $\mathbf{2 8 ( 2 3 \% )}$ & $\mathbf{9 ( 7 \% )}$ & $\mathbf{1 2 4}$ \\
\hline
\end{tabular}

\section{Key results by Cluster}

\section{Economic Cluster}

This cluster covers the Macro Economic and Financial sector, Private Sector development and the economic sectors of Agriculture, Infrastructure (Energy, Transport, and ICT and STI), as well as Environment and Natural Resources management

The GDP estimates calculated at constant 2006 prices show that in $2009 / 10$ the GDP was $6.2 \%$ higher in real terms than in 2008/09. This follows an increase of $9.8 \%$ from $2007 / 08$ to $2008 / 09$. This growth rate is mainly attributed to the growth in the agriculture $(5.9 \%)$ services $(7.6 \%)$ sectors as the sector of industry only grew by $0.6 \%$.

After reaching $22.3 \%$ in December 2008, inflation declined strongly in 2009. It continued to be low in 2010 and the annual change stood at $5.03 \%$ by end-June 2010 compared to $9.4 \%$ at the end of June 2009 (an annual average of 4.8\%) partly reflecting lower international prices, growth in agriculture production and controlled monetary growth by the Central Bank (BNR).

Total domestic revenue collections were RWF 391.5 billion (12.4\% of GDP), it exceeded the projected amount of RWF 385.1 billion by about RWF 6.4 billion as higher collections from direct taxes and some indirect taxes offset shortfalls under taxes on international trade and non tax revenues. Despite lower than projected foreign financing and, net domestic financing has 
been kept below $0.5 \%$ of GDP thanks to lower spending and credit to private sector reached $11.75 \%$ of GDP.

Partially due to the global economic slowdown, exports of goods and services declined by $9 \%$ while imports grew at a slower rate of $7 \%$ compared to $17 \%$ in 2008/09. Despite the decline in exports, the ratio of Net Present Value of external public debt to exports remained well below the $150 \%$ threshold.

Rwanda was declared as the World's top reformer of business regulation last year in the Doing Business 2010 (reflecting on 2009 data). Rwanda made it easier to start a business, register property, protect investors, trade across borders, and access credit. The country has made the big strides in becoming business friendly by introducing reforms in seven out of the 10 categories, emerging to $67^{\text {th }}$ position out of 183 countries on the Doing Business rankings becoming the first sub-Saharan country to achieve this position.

A Prime Ministerial order enforcing time limits for the delivery of construction permits and instituting sanctions for failure to deliver has started being enforced. Average time has reduced from 210 days to less than 30 days to obtain a construction permit. For Kigali City, a One Stop Centre for construction permits has been established and housed in Nyarugenge district offices to ensure the time prescribed by the client charter is respected.

A detailed tariff study has been conducted with the objective of determining recommended electricity tariff levels considering long run marginal cost and affordability while also looking into a new tariff structure for different consumer groups. These levels shall feed in tariffs for decentralized power plants like micro hydro power plants. The final study report was validated with all key stakeholders on $26^{\text {th }}$ October 2010.

The Fuel Levy was increased from frw 22 to RWF 62. This will impact on the improvement of the road condition, as more revenues will be collected from the fuel level. Thus in the subsequent years, more roads will be rehabilitated both on National and District road classification network.

In order to increase the proportion of arable land sustainably managed against soil erosion, nine feasibility studies were completed during the financial year 2009/10, meaning that a total of 17 feasibility studies have been completed since the inception of LWH (compared to the target of 18). 8 of these have been made available; the other 9 are awaiting internal validation and will be shared immediately. Thus, $90 \%$ of this target has been achieved.

In regard to the preparation of the National land Use and Development Master plan, aerial photography of $96 \%$ of Rwanda's territory was taken and high resolution ortho-photos and digital elevation model produced. Satellite imagery for the remaining $4 \%$ procured and are undergoing rectification. Planned sectoral studies completed and approved by Steering Committee, these have been used to develop alternative development scenarios. Consultation on these draft scenarios, suitability and needs assessment were carried out in May and June 2010.

Law establishing and organizing the real property valuation profession in Rwanda was Gazetted in May 2010. Members of the valuation board were appointed and the board put in place; Real estate valuers are in the process of forming an institute. 


\section{Social Cluster}

The infant mortality rate (IMR) has decreased from 86 to 62 per 1,000 live births (2012 target is $62 / 1,000)$ and the under-5 mortality rate (U5MR) has decreased from 152 to 103 per 1,000 live births (I-DHS 2008).

The maternal mortality ration has decreased from 750/100,000 live births (DHS 2005) to 383/100,000 live births in 2008 (Maternal Mortality for 181 countries, 1980-2008, a systematic analysis of progress towards MDGs, 2008).

The proportion of women continuing to use modern contraceptive methods among women in union is $53.6 \%$ and $29 \%$ among women of reproductive age (HMIS 2010). The percentage of women aged 15-49 years using modern contraceptive methods increased from $38.1 \%$ to $45.1 \%$ (HMIS 2009) from June 30th to 31st December 2009. The overall modern contraceptive proportion: 45\% (HMIS 2010).

The case fatality rate of patients hospitalized with malaria has reduced to 3,5\% (HMIS 20092010). In 2009-2010 a total of 2,727,710 LLINs have been distributed countrywide: $1,566,559$ LLINs distributed to the under 5 children countrywide through $\mathrm{MCH}$ week campaign in April 2010, 352650 LLINs have been distributed through ANC services and data will be collected during the DHS 2010. 808,501 LLINs were distributed to the households, orphans, trainings and inpatients.

The percentage of assisted births in an accredited facility has significantly improved from a baseline to an estimated $63.5 \%$ in 2009 well above the targeted $40 \%$ for $2009 / 10$, already achieving the EDPRS target for 2012. The percentage of women aged 15-49 using modern contraceptive methods increased from a baseline of $10 \%$ in 2006 to an estimated $45 \%$ in 2009 , exceeding the target of $32 \%$ set for $2009 / 2010$.

Immunization coverage has increased to above $80 \%$ for all antigens by the end of 2009 . On the indicator measuring the percentage of children using Long Lasting Insecticide Treated Nets (LLITN), significant progress was made, reporting a score of $60 \%$ in 2008 from a baseline of $16 \%$ in 2006 . The utilization rate of primary health care services also increased from $70 \%$ to $86 \%$ in advance of the $80 \%$ target that was set for 2010 .

Immunization coverage has increased to above $80 \%$ for all antigens by the end of 2009 . On the indicator measuring the percentage of children using Long Lasting Insecticide Treated Nets (LLITN), significant progress was made, reporting a score of $60 \%$ in 2008 from a baseline of $16 \%$ in 2006 . The utilization rate of primary health care services also increased from $70 \%$ to $86 \%$ in advance of the $80 \%$ target that was set for 2010 . 
In 2009/10, an estimated 7.62 million people equivalent to $76.2 \%$ Rwandans had access to safe drinking water supply within 500 Meters in rural areas and 200 Meters distance in urban areas . This is $2.2 \%$ increase compared to $74 \%$ access registered at the end of mid budget between January to June 2009. According to the EDPRS target, in 2012 , access to clean drinking water within $500 \mathrm{~m}$ in rural areas is $86 \%$.

54 sensitization committees on Hygiene through PHAST and HAMS committees were setup in different Districts where they did not exist. The setup of these committees will mobilize the population to use and develop sanitation facilities in the communities.

The 9 year basic education was successfully implemented for the first year to scale-up access to education. About 3,140 new classrooms were constructed to provide space for 9YBE and equipped with 74,046 desks. 765 schools are now offering 9YBE, 522 of which are new. The overall completion rate for P6 has increased from 52\% to $75 \%$ in 2009 , the completion rate for a girl is still higher (78\%) compared to that of boys $(71 \%)$. The transition rate from primary to secondary school has also increased from $54 \%$ in 2008 to $88 \%$ in 2009 . In addition 5,834 latrines were constructed in various schools to improve hygiene.

Science practical materials were distributed to different science centers and practical exams were held for the first time in secondary school across the country. More so, Technical and Vocational Training were given more attention as 100 trainers were trained in Singapore and Philippines while 316 teachers were trained locally in vocational training. Kicukiro Polytechnic was reconstructed while other Integrated Polytechnic Regional Centres were given equipments.

The VUP program has been successfully scaled up to 60 sectors exceeding the targets. Of the households eligible for support, the percentage granted public works was targeted at $35 \%$ which was fully realized. The percentage of households eligible for support and granted direct support in VUP sectors has reached $100 \%$ exceeding the target.

\section{Governance Cluster}

The targeted percentage of strengthen local government capacities to improve access to quality services, sustain socio-economic development, manage and coordinate sector strategies was $65 \%$ in $2009 / 10$ and according to the monitoring \& evaluation the implementation 2009/2010 Imihigo exercise carried out in June 2010 that covered all 30 districts, $67.2 \%$ is the average score but the best district got $79.3 \%$. Nyamasheke emerged the best district. This time around the ranking was quite peculiar and transparent where districts were ranked from the first to the last.

A Citizen Report and Community Score Card exercise is another key achievement in the sector. This citizen Report and community score card was conducted and validated in March 2010. This assisted in assessing capacity (institutional, organizational, and operational) at all levels in order to strengthen and improve access to quality services and sustain socio-economic development. The Joint Governance Assessment and results indicated that about $86 \%$ of the population was happy with service delivery while $72 \%$ of the population rated Local Government Accountability and responsiveness of local leaders as very good. The other findings from the survey were also institutionalized by carrying out sector specific validation meetings. 
The Internship Programme for new Graduates from different Rwanda Universities was launched with 102 internees selected, and of these 100 people, 77 persons are now hosted within the Internship Programs. 271 Internees started the second phase of internship program in March 2010. The Internship Programme for new Graduates from different Rwanda Universities and out side Rwanda was launched in March 2010.

Justice, Reconciliation Law and Order Sector was adopted by the Cabinet decision $\mathrm{n}^{\circ} 4$ of 16 th December 2009. The Ministry of Justice, the Supreme Court, the NPPA and the Police carried out trainings on members of different committees covering security, reconciliation, and justice issues on district level. The Minister's instruction on the mandate, objectives, and tasks of the JRLOS Technical committees were discussed in the JRLOS TWG. Here it was stated that there are already different committees active on the district level coordinating security and justice as well as reconciliation issues. These are the security committees on district level, and the Justice Committees on the level of intermediary courts. The TWG proposed to carry out a mapping of committees on district level, and to clearly determine the focus of the different existing committees, and especially the needs of the population to determine the necessity for a further committee.

The Commercial Court structure is established and fully operational. The backlog of commercial cases has been eliminated. Judges have undertaken Master degrees in South Africa, registrars have been trained and all staff has undertaken English language training. Several judges are being trained including 7 judges completed master's degree in commercial law in South Africa in July 2009, 3 judges are completing master's degree in commercial before December 2010, 5 more judges were send to SA in July 2010 to pursue Master's Degrees.

In order to improve on the quality and timeliness of annual financial statements, $40 \%$ of all budget agencies were to submit their internal audit reports in 2009/10. This target was exceeded as $45 \%$ of all budget agencies submitted their internal audit reports in 2009/10 financial year.

On $1^{\text {st }}$ July 2010, following a short piloting phase between April and June 2010, the core modules of the IFMIS were rolled out to 94 out of 236 budget agencies. Current efforts are focused on providing sufficient end user support, developing key functionalities that enhance the performance and controls embedded in the business processes of the core modules, and developing operational and management reports for end users. The IFMIS will be rolled out to the rest of the budget agencies in two additional phases.

The government portfolio strategy was prepared, approved and is under implementation. A fully fledged Government Portfolio Unit was set up in MINECOFIN and on-the-job training for the Unit's staff was carried out by PwC in March 2010. A fiscal risk review report for all GBEs was prepared by the Unit in June 2010.

\section{Key critical issues/challenges}

A number of critical issues that emerge from the self evaluations provided by the different sectors include the following that need a particular attention: 
- The EDPRS results and policy matrix is mixing outputs and outcomes. Also most policy actions are outputs or activities. Indicators don't always measure the outputs or outcomes and some policy actions are not directly contributing to the set targets. Therefore the matrix should be revised to reflect the logic of the theory of change. It is recommended to include guidelines in that sense into the TOR for the next forward looking JSR (March 2011).

- Quality of existing M\&E frameworks: In the view of theory of change, M\&E frameworks are not well defined (i.e outcomes, outputs, indicators and targets are not well defined). Also, Indicators from the sectors are voluminous such that tracking progress becomes difficult.

- Low investment in key sectors: the current situation shows that mortgage and real estate as well as agri-business are the least well financed through bank loans, despite their importance to our economic development. For example demographic and urbanization projections show that there is a need for 25,000 new houses every year, at an average cost of Rwf 500 billion, when in 2009/10 only Rwf 53.3 billion was granted for this purpose. The total amount of loans distributed in the agri-business represented just $1 \%$ of all loans granted by banks, even though the agriculture sector represents around $33 \%$ of the GDP.

- Close follow-up is needed on Investment code revision that waits to be harmonized with EAC investment Laws and subsequent finalization of respective studies.

- Finalization of studies on assessment of legal, policy and institutions framework and Investment opportunities in EAC,

- Due to the remarkable increase in the agriculture production, a strong focus should be put on the improvement of postharvest and strategic storage in order to minimize losses and to continue to tackle malnutrition (MDG). USAID and WFP have offered to train on warehouse management and post-harvest management. Therefore, it is recommended that MINAGRI undertake analysis of potential consequences of Strategic Grain Reserve (e.g. different management approaches, fiscal implications, etc) as part of its design;

- The productions of coffee and tea have recorded low increases towards achieving EDPRS targets. Thus, it is recommended that MINAGRI conduct a mid-term evaluation of key EDPRS targets as well as a review of the targets for which performance has already been exceeded in preparation for the next forward looking JSR in which targets and actions can be revised.

- Lack of staff capacity to implement programmes and projects: this is a big challenge that affects the entire road transport network and subsequently the two CPAF indicators without forgetting that this sub-programme covers the big share of the budget in Transport sub sector. Therefore the development of classified road network Infrastructure to meet good conditions requires well-trained and capable staff to do it.

- Closer follow up of tree plantation exercise is required to assess why in some areas there is high percentage loss of trees planted. Overall losses amounted to close to $30 \%$ of the trees planted in 2008 
- Many health facilities managed by churches do not deliver modern contraceptive methods. This requires the establishment of a secondary health post in the vicinity of faith based Health Facilities hence more additional resources/budget required.

- Though the Ministry of Education is one of the Ministries to get an important portion from the total budget of the country, the uniqueness and importance of activities that were planned for at national level has made it impossible to operate within the allocated budget. Therefore, most institutions under the Ministry were given a small portion of their required budget and were requested to try to cope with or where applicable encouraged to generate income to top up this budget.

- The absence of a social protection sector strategy has made it hard for some stakeholders to contribute effectively the overall performance of the sector. The Strategy that is being prepared sets out to address this challenge and therefore needs a close follow up.

- A decision to channel government support through a youth window that has to be established under Umurenge Sacco was reached and that COOJAD would be phased out. This requires a close follow up and inform all stakeholders.

- Interventions by different stakeholders in the Decentralization, Citizen Participation, Empowerment, Transparency and Accountability (DCPETA) Sector need a proper coordination and communication system to avoid duplication of efforts. Hence a need for harmonization of donor intervention

- The established Task Force focusing on the treatment of minors in conflict with the law will establish a first baseline concerning the quantity of juveniles in detention, their treatment, and the time spent in detention. This task force will come up with proposals to improve the treatment of minors. Furthermore the legal aid week will again focus on the assistance to minors.

- Low levels of PFM capacity at Central Government, Districts, Provinces and facilities such as hospitals, schools and prisons- This challenge is being addressed by ensuring that adequate human resources are availed to all Government entities, undertaking institutional restructuring and by carrying out continuous capacity building programs.

\section{General observations}

1. In overall, a total of $\mathbf{1 2 4}$ policy actions were planned for 2009/10. Out of these, a total of 87 policy actions $(\mathbf{7 0} \%)$ were completed $(\mathbf{G}), 28$ policy actions $(\mathbf{2 3 \%})$ were partially achieved (Y) and 9 policy actions (7\%) were lagging significantly behind (R). Corresponding targets were also implemented as follows: Out of 73 targets planned, 54 were fully achieved (74\%), 7 targets were partially achieved (10\%), 2 targets were not achieved (3\%) and $10(14 \%)$ targets were not assessed due to ongoing surveys that will provide the required data. Though some of these policy actions were implemented with 
delays compared to plans, in some areas, it was realized that some of the targets have been exceeded.

2. Therefore this shows that the Government of Rwanda has shown its commitment in implementing the set goals in the Economic Development and Poverty Reduction Strategy (EDPRS) 2008-2012. It is therefore striving to achieve higher program performance, and consequently higher social and economic development.

3. In most areas, it was observed that some of the targets have been exceeded. In these areas the projections for the future need to be revised upwards in order to match with higher performances of clusters and their corresponding sector.

4. On the whole, the concept of Imigiho as a development strategy has led to promising results by promoting a competitive spirit and creating focused and enthusiastic effort which are essential components to the long awaited development. In addition, the strategy has promoted an effective mechanism of monitoring and evaluation of development initiatives, which is essential to promote focused development.

5. There is need to address the ambiguity that is apparent in the EDPRS Results and Policy Matrix/CPAF (in the view of the theory of change). Most of the statements indicated as outcomes/ outcome indicators are actually outputs. The layout of the EDPRS Matrix should be redesigned to clearly show outcomes and their indicators. Some targets are unrealistic and others expressed in measures that are not appropriate. The sectors will have to redesign some targets, add the missing targets and baselines.

6. The theory of change is needed to review the outcomes \& indicators of the EDPRS and setting up a task force for each of the 3 strategic results may be necessary to ensure their implementation at sector level.

7. There is a need to continue to improve Cross Cutting Issues coverage in the EDPRS monitoring and Evaluation by reaffirming its importance for the implementation process.

\section{INTRODUCTION}

This report provides the progress on implementation of the Economic Development and Poverty Reduction Strategy (EDPRS) from July to December 2009. It is based on the selected Policy Actions in the EDPRS Results and Policy Matrix as well as CPAF for 2009/10 financial year.

The EDPRS Results and Policy Matrix contain the full set of selected indicators, targets and policy actions being monitored by the Government of Rwanda (GoR) at Central level. There are however, a wider range of indicators, targets and policy actions monitored at Sector level than those contained in the Matrix. 
The EDPRS Results and Policy Matrix is organised around 3 major strategic objectives of:

4. Increased economic growth

5. Managing population growth rate and enhancing population development

6. Enhanced gains through good governance.

Within each strategic objective there are a number of strategic outcomes, together with associated indicators and targets being monitored at national level as well as related policy actions.

Each EDPRS sector contributes to the implementation of one or more strategic outcomes under the strategic objectives, through its fulfilling of agreed policy actions.

The analysis of performance is based on self assessment provided by each sector on progress at the end of June 2010; the report provides explanations of why performance has been limited or where progress was slow. The reporting method uses a 'traffic lights' scorecard, which visualises the information in a very accessible and user-friendly way.

The traffic light colour coding rates progress: green indicates that the policy action was 'fully achieved', yellow indicates that the policy action was 'partially achieved' and red indicates that the implementation of the policy action is 'off-track' , 'not met' or was lagging significantly behind.

The report is structured under three Clusters; Economic, Social and Governance, established by the Kivu Leadership retreat of Government. 


\section{ECONOMIC CLUSTER}

This cluster covers the Macro Economic and Financial sector and the economic sectors of Agriculture, Infrastructure (Energy, Transport), Private Sector development as well as Environment and Natural Resources management.

\subsection{MACRO ECONOMIC AND FINANCIAL SECTOR}

9 major Policy actions were planned /set; 7 fully achieved and 2 partially implemented. The sector had 6 corresponding targets, 5 fully achieved and 1 partially achieved.

In 2009/10, Rwanda continued to build on the impressive growth of 2008/09, despite the global financial crisis. Real growth rate reached $6.2 \%$ moving the 5 year average to $8.5 \%$.

In the fiscal year 2009/10, GDP at current prices was estimated to be Rwf 3,160 billion up from Rwf 2,843 billion in the year ending June 2009. In this fiscal year, the population of Rwanda was estimated at 10.2 million people. GDP per head was therefore Rwf 308,000 or US\$ 541 at the nominal exchange rate of Rwf 569 to 1 US dollar.

The GDP estimates calculated at constant 2006 prices show that in 2009/10 the GDP was $6.2 \%$ higher in real terms than it was in 2008/09. This follows an increase of $9.8 \%$ from $2007 / 08$ to $2008 / 09$. This growth rate is mainly attributed to the growth of the three main sectors in this fiscal year were $5.9 \%$ for agriculture (mainly driven by a $7 \%$ increase in the food crop production), $0.6 \%$ industry and $7.6 \%$ for services (in which public administration grew by $10 \%$ and business services by $13 \%$ ).

At 2006 constant prices, in the fiscal year 2009/10 Government and Private Final Consumption Expenditure grew by $7 \%$ and $12 \%$ respectively. Gross Capital Formation in real terms fell back by $7 \%$ after two years of exceptional increases (24\% and 28\%). Exports of goods and services also fell by $9 \%$, while the rate of increase in imported goods and services slowed to $7 \%$ from $17 \%$ in $2008 / 09$.

Tax revenue increased by $10.4 \%$ over 2009 , with the largest gains made in taxes on goods and services (VAT). The headline figure disguises the decline observed in international taxes $(-3 \%)$, due largely to the full EAC membership. Despite the gains in the absolute levels of revenues, collections did not keep pace with the increasing GDP, such that the ratio of domestic revenues to GDP fell from $14.9 \%$ to $12.6 \%$.

In exports, the major story was the huge declines in prices achieved for mineral products - of up to $40 \%$. This was anticipated and was not in fact quite as bad as feared, although the losses were significant. An unexpected result was the $20 \%$ decline in coffee receipts, a direct result of the $17 \%$ decline in volumes produced - this is in part due to delays in coffee financing that occurred earlier in the year. On the imports side, import prices continued to increase (albeit at a slower rate). Coupled with a significant increase in volumes imported ( $40 \%$ in consumption goods alone, 
with over $50 \%$ increases in cereals and cooking oils - two of the largest contributors), the value of imports rose by $8.2 \%$.

The defining theme in the monetary sector for 2009 was the domestic 'credit crunch' - a mismatch of assets and liabilities in the banking system that saw credit to the private sector decline by almost $2 \%$ over the year.

From a high inflation rate of $22.3 \%$ in December 2008, the annual headline inflation fell to $5.74 \%$ in December 2009. The underlying inflation, which does excludes fresh foods and energy, dropped to 3.5\% in December 2009 from 22.1\% in December 2008. The objective of keeping inflation in one digit number in 2009 was largely achieved. Whilst due in part to the steep reduction in the price of imported goods (which can have a significant 'feed-through' effect), the tight monetary policy employed by BNR and the increased agricultural output also helped to bring downward pressure on prices.

From the last quarter 2009, particularly in November and December, the credit to private sector has been increasing. For instance, between September and December of 2009, the outstanding credit to private sector increased by $2.65 \%$ following the regained confidence in the banking system, stimulated by different measures taken by BNR and the Government, which include the reduction of reserve requirement, the introduction of BNR refinancing facility against collaterals as well as the Government long term deposit facilities.

Following the publication of the new banking law, the process to update the prudential regulations has been ongoing during 2009. As of end August 2009, the regulations on liquidity ratio, capital adequacy requirements and regulation on accreditation and other requirements for external auditors of banks and Insurance and Insurance Brokers have been issued to all banks.

\section{Key issues}

The following are some of the key issues facing the macro economic and financial sector;

- Insufficient long term financing: although BNR together with the Government put in place some measures and facilities intending to restore the liquidity within the banking system, long term financing is still very weak and needs to be boosted.

- Low investment in key sectors: the current situation shows that mortgage and real estate as well as agri-business are the least well financed through bank loans, despite their importance to our economic development. For example demographic and urbanization projections show that there is a need for 25,000 new houses every year, at an average cost of Rwf 500 billion, when in 2009 only Rwf 53.3 billion was granted for this purpose. The total amount of loans distributed in the agri-business represented just $1 \%$ of all loans granted by banks, even though the agriculture sector represents around $33 \%$ of the GDP. 
- High stock of nonperforming loans: there is a huge stock of nonperforming loans which constitutes one of the barriers that hinder banks to finance some long term projects.

\subsection{PRIVATE SECTOR}

The aspirations of Vision 2020 are expected to be realized around six main pillars among which, "a private sector led economy". It has been recognized that the emergence of a viable private sector that can serve as the principle engine of the economy is key for Rwanda's development. Also, the EDPRS assigns the highest priority to accelerating growth to create employment and generate exports. This will be achieved through an ambitious, high quality public investment programme aimed at reducing the operational costs of business. This big push will create strong incentives for the private sector to increase its investment rate in subsequent years.

5 policy actions set; 3 fully met and 2 partially met. The sector had 5 corresponding targets, 4 fully achieved and 1 partially achieved.

Rwanda was declared as the World's top reformer of business regulation last year in the Doing Business 2010 (reflecting on 2009 data). Rwanda made it easier to start a business, register property, protect investors, trade across borders, and access credit. The country has made the big strides in becoming business friendly by introducing reforms in seven out of the 10 categories, emerging to $67^{\text {th }}$ position out of 183 countries on the Doing Business rankings becoming the first sub-Saharan country to achieve this position. Key reforms implemented include:

\section{Starting a Business}

One (1) procedure carried out in one (1) day for registering businesses has been implemented. Online business registration is now operational. This means that a company

Moreover, full business registration (incl. access to TIN number) is now fully operational. This means that a company may be incorporated remotely or abroad without necessarily being in Rwanda.

\section{Trading Across Boarders}

i) A one stop border concept post has been established at Gatuna (border with Uganda) and Nemba (border with Burundi) with ongoing plans to create additional ones later this year. Gatuna alone processes three quarters (3/4) of total Rwanda trade. 24hour border operations have commenced at Gatuna (Uganda-Rwanda) border and La Corniche (Rwanda DRC).

iii) Trade documents have been streamlined with the removal of the cargo release order and replacing it with a stamp. Customs officers now collect Rwanda Bureau of Standard fees thus reducing multiple queues and saving time for businesses in goods clearance.

v) Customs procedures have been harmonized with the EAC region while non-tariff barriers such as issuance of simplified certificates of origin and allowing final clearance of goods at the border posts have been addressed.

vi) A semi-automated single window at Customs has been put in place (already done at SDV) and to be implemented at Gikondo, Airport, Gatsata and Kabuye oil depots. A fully automated system including outer stations and all border posts is slated for May 2011. 
vii) Efforts are also underway to establish an electronic single window. A new system, Asyscan, has been introduced and this enables electronic submissions of customs declarations and attachments.

\section{Construction permits}

A Prime Ministerial order legalizing/enforcing time limits for the delivery of construction permits according to the client charter and instituting sanctions for failure to deliver has been gazette and is being enforced. An appeal mechanism for applicants has also been established. Average time has reduced from 210 days to less than 30 days to obtain a construction permit.

ii) A one stop construction permit centre has been established and housed in the Nyarugenge district offices to ease construction and ensure the time prescribed by the client charter is respected. The results already speak for themselves.

iii) Fees and costs related to construction permits have been streamlined through an instruction, issued by the Chairman of the Advisory Board of Kigali city (highest governance structure) and have been published in the official gazette. Procedures have been reduced with a merger of all inspections done into one procedure (inspections of land, electricity and water). A public notice has been issued by the Mayor of Kigali city and published in the official gazette

All borders have been connected to the ASYCUDA (customs software) network except Rutete due to the lack of energy. Electrification process is being done by RECO, it will be connected soon.

Infrastructure development including roads and electricity in Free trade zone in Nyandungu is being done by Horizon and partners. Final and detailed architectural designs and bills of quantity complete. The expropriation of phase 1 which is about 98 ha was completed and about 500 families were compensated.

Licensing reform was finalized and approved by the Cabinet.

RDB took a number of initiatives to promote the diversification of tourism in Rwanda. One of the key initiatives is the Birding that was launched as a new product with identification of a bird tourism circuit, including the ongoing construction of a canopy walk at Uwinka in Nyungwe National Park.

Cave tourism in Busanze is going to be reopened. Cultural tourism products including dance troupes and the city tour are being reinvigorated.

\section{Key Issues}

- Close follow-up of Investment code revision that waits to be harmonized with EAC investment Law and revision will fellow after finalizing of other related studies. 
- Finalization of studies on assessment of legal, policy and institutions framework and Investment opportunities in EAC.

\subsection{INFRASTRUCTURE SECTOR}

The key objectives of the infrastructure sector during the EDPRS period are: to reduce transport costs within the country and between Rwanda and the outside world, and to ensure security of energy supplies by increasing domestic energy production from several sources. In meteorology, the aim is to provide a wide range of timely, high quality information to different groups of users.

This sector covers sub sectors of energy and transport in the EDPRS results and Policy matrix.

\subsubsection{ENERGY SUB SECTOR}

3 policy actions set and 3 were fully completed, with all 2 indicators fully implemented.

The law establishing the Energy and water board was passed by the Parliament and this is a strong achievement within the new setup of restructuring the Ministry and appropriate management of Energy and Water in the Country.

A detailed tariff study has been conducted with the objective of determining recommended tariff levels considering long run marginal cost and affordability while also looking into a new tariff structure for different consumer groups. These levels shall feed in tariffs for decentralized power plants like micro hydro power plants. The final study report was validated with all key stakeholders on $26^{\text {th }}$ October 2010.

828 biogas digesters have been constructed to replace biomass energy in households with minimum of 2-3 cows.

Experts (hydropower, geothermal, Lake Kivu monitoring,) in different fields have been recruited to support the successful development of Rwanda's energy sector and resources. Experts will also assist in negotiations and transactions with private sector companies that are increasingly getting involved in energy sector projects.

\section{Overall Budget Execution 2009/2010 Budget}

\begin{tabular}{|l|l|l|l|}
\hline & $\begin{array}{l}\text { Allocation } \\
\text { (RWF) }\end{array}$ & Execution (RWF) & \% execution \\
\hline Total Budget & 27010929884 & 30333146810 & $112.3 \%$ \\
\hline Recurrent Budget & 10673929884 & 10232074553 & $95.9 \%$ \\
\hline Development Budget & 16337000000 & 20101072257 & $123.0 \%$ \\
\hline
\end{tabular}


As seen from above, the budget execution for 2009/10 was $112.3 \%$, 95.9\% for recurrent expenditure and $123 \%$ for development expenditure. This shows that Energy Sector overexecuted its budget during the financial year on the development budget. This is mainly due to over-execution on two projects: the construction of hydropower plants and the rapid implementation and under-budgeting for the electricity roll out programme under the high priority distribution and transmission projects.

\section{Key issues}

- Existing projects or those in pipeline, sometimes run short of financing to complete them in the due time. The challenge is beyond the sector capacity but budget constraint.

\subsubsection{TRANSPORT SUB SECTOR}

The objectives of the Transport Sub-sector are: (i) improve transport links internally and internationally; (ii) reduce and keep transport costs under control; (iii) improve the institutional framework and strengthen the capacity of partners involved in the sector; (iv) improve road safety; (v) achieve sustainable financing of road maintenance; and (vi) maintain the roads rehabilitated or constructed. Priority during the EDPRS period will be placed on maintaining and rehabilitating the road network, including feeder roads in rural areas, through enhancing the financial capacity of decentralised administrations for road maintenance.

4 policy targets set; 2 fully implemented and 2 partially implemented. It had 2 indicators, 1 was fully implemented, while another one partially implemented.

The Fuel Levy was increased from frw 22 to RWF 62. This will impact on the improvement of the road condition, as more revenues will be collected from the fuel level. Thus in the subsequent years, more roads will be rehabilitated both on National and District road classification network.

Road condition survey of 2010 revealed that overall condition of the National Road network, shows that $38.1 \%$ are in good condition hence exceeding the EDPRS target of the year 2012, which is $31 \%$. However the District Unpaved road network in good condition is $23 \%$ using IRI method, marginally below the target of $28 \%$ which was set using the data from Visual Inspection method. Subsequently the road condition survey using Visual Inspection Method gave 54\% of the District Road network in good condition. However, after the survey, RTDA decided to change from Visual Inspection to IRI as the appropriate tool to measure the road network condition in Rwanda.

In the area of Regulation \& Road Safety, a study for rehabilitation and modernization of road sign was completed in 2009 and is now awaiting execution. A sensitization campaign on road safety was conducted. The incremental impacts of accident for driving odd vehicle having opposite site steering control was conducted in 2009. The recommendations of the study are now waiting for Cabinet approval. 


\section{BUDGET EXECUTION}

Overall budget execution in Transport sub-sector i.e. in RTDA during 2009/2010 fiscal year was satisfactory achieving $97 \%$ of the allocated budget. The execution rates for recurrent and development budgets were also satisfactory, i.e. $93 \%$ and $102 \%$ respectively as demonstrated in the Table below.

\section{OVERALL BUDGET EXECUTION 2009/2010 BUDGET}

\begin{tabular}{|l|l|l|l|}
\hline & $\begin{array}{l}\text { Allocation } \\
\text { (RWF) }\end{array}$ & $\begin{array}{l}\text { Execution } \\
\text { (RWF) }\end{array}$ & $\begin{array}{l}\% \\
\text { Execution }\end{array}$ \\
\hline Total Budget & $26,124,870,669$ & $25,413,225,413$ & $97 \%$ \\
\hline $\begin{array}{l}\text { Recurrent } \\
\text { Budget }\end{array}$ & $14,281,870,669$ & $13,318,510,190$ & $93 \%$ \\
\hline $\begin{array}{l}\text { Development } \\
\text { Budget }\end{array}$ & $11,843,000,000$ & $12,094,715,223$ & $102 \%$ \\
\hline
\end{tabular}

Although overall budget execution in the 2009/2010 was satisfactory, the budget execution of some programmes of the transport sub-sector has been affected by a number of reasons as follows:

- In addition to the initial delay due issues related to the road widening (technical and financial considerations) and the project was further delayed due to problem in land appropriation and getting environmental clearance for construction sites.

- Rehabilitation and reconstruction work of $36 \mathrm{~km}$ of Kigali City road was also delayed due to land appropriation problem.

- Delays in starting works on Ngororero - Mukamira road $(55 \mathrm{~km})$ rehabilitation projects was due to internal procedures of the Kuwait Fund for Development, which are very slow and the procurement regulations on the appointment of the works supervisor. In addition, there has been a change in percentage and currency of payment by BADEA and this affected the payment procedures to the contractor

\section{Key issues}

- Districts are not producing reports on the implementation of Infrastructure activities done on the disbursements from Road Maintenance Fund.

- Lack of staff capacity to implement programmes and projects: this is a big challenge that affects the entire road transport network and subsequently the two CPAF indicators without forgetting that this sub-programme covers the big share of the budget in Transport sub sector. 
Therefore the development of classified road network Infrastructure to meet good conditions requires well-trained and capable staff to do it.

- Lack of enough budget to implement programmes: New programmes are not planned because the budget is sufficient to continue the ongoing projects only. This hinders the entire development of transport infrastructure and genuinely affects the condition of classified road network.

\subsubsection{ICT AND SCIENCE, TECHNOLOGY AND INNOVATION SUB SECTOR}

ICT had planned to implement 2 policy actions and all were fully implemented. The sector had 2 corresponding targets and all fully achieved.

As an element in the Growth Flagship program, the science and technology sector contributes to the EDPRS goal of promoting science, technology and innovation for economic growth. But it is also supportive of other EDPRS goals and Flagship programs.

Composite coverage network is now at more than $90 \%$ with the increased number of telecommunications operators following the introduction of Rwandatel and TIGO in addition to MTN that was already in the market. The competition has provided consumers with reduced cost of telecommunication services as subscription fee for mobile service was reduced down to zero francs, calling rates per minute was reduced by $32 \%$ from Rwf 147 in 2003 to Rwf 100 in 2008. The mobile telephone coverage is $92 \%$ of the total population who can use telephone while the number of internet subscribers has been increased by 157,570 in 2009/10 from 1,322,637 in 2008. So far $1700 \mathrm{Km}$ of $2500 \mathrm{Km}(68 \%)$ fiber optic has been laid out to facilitate cheap and high -speed internet connectivity. 50 public institutions are connected and using the fiber optic. While over 300 people in Kigali are testing the Kigali City Wireless Broadband (Wibro). Construction has currently reached all Rwandan borders and RDB is in negotiation with neighboring countries like Uganda and Tanzania to be linked to the submarine cable.

So far $1700 \mathrm{Km}$ of $2500 \mathrm{Km}$ (68\%) fiber optic has been laid out to facilitate cheap and high speed internet connectivity. 50 public institutions are connected and using the fiber optic. While over 300 people in Kigali are testing the Kigali City Wireless Broadband (Wibro). Construction has currently reached all Rwandan borders and RDB is in negotiation with neighboring countries like Uganda and Tanzania to be linked to the submarine cable.

\subsection{AGRICULTURE SECTOR}

The agriculture sector has made good progress in moving towards achieving MDG1, the Vision 2020 goals and EDPRS targets. In 2009/10, the agricultural output recorded a significant increase in growth rate of over 9\% mainly driven by the Crop Intensification Program which has seen an improvement in the use of fertilizers, improved seeds and better planting techniques under the land consolidated. The healthy growth in agriculture has helped to propel the economy to higher growth rates by generating over $33.8 \%$ of GDP. 
10 policy actions set; 8 (80\%) fully implemented and 2 partially achieved. The corresponding targets were 6 and were all fully implemented (100\%).

In order to increase the proportion of arable land sustainably managed against soil erosion, nine feasibility studies were completed during the financial year 2009/10, meaning that a total of 17 feasibility studies have been completed since the inception of LWH (compared to the target of 18). 8 of these have been made available; the other 9 are awaiting internal validation and will be shared immediately. Thus, $90 \%$ of this target has been achieved.

In order to increase agricultural productivity, the percentage of land area protected against soil erosion has significantly increased from a baseline of $44.5 \%$ in 2008 to an estimated $81 \%$ in 2009 well above the targeted $50 \%$ for $2009 / 10$.

The first draft showing the results and lessons learned of an evaluation study of the fertilizer strategy was produced. This was shared with the Agriculture Sector working Group in April 2010 and thereafter it is finalized after their comments/input captured. This policy informed the development of an exit strategy, which was also agreed with the ASWG and completed in 2009/10.

\section{Budget execution 2009/10}

\begin{tabular}{|l|l|l|l|}
\hline & Allocation (RwF) & Execution (RwF) & \% execution \\
\hline Total Budget & $31,089,002,890$ & $27,928,491,031$ & 89.9 \\
\hline Recurrent Budget & $7,001,145,390$ & $6,048,609,331$ & 86.4 \\
\hline Development Budget & $24,087,857,500$ & $21,879,881,700$ & 90.8 \\
\hline
\end{tabular}

As can be seen from the above table, execution rates in 2009/10 were good overall, with total budget execution being about $90 \%$. There was a slightly a lower execution in the recurrent budget (of $13.61 \%$ ), while the development budget was executed at approximately $91 \%$. The reason for lower execution on the development budget part was due to two internally-financed projects, namely the Crop Intensification Programme and the Rice Rehabilitation Scheme, and due to a shortfall in execution for counterpart funds for the Land Husbandry, Water Harvesting and Hillside Irrigation (LWH) Project. However, it is worth noting, that LWH funds were fully engaged on the $30^{\text {th }}$ June 2010 and execution started in July 2010.

\section{Key Challenges and lessons learnt}

- Due to the remarkable increase in the agriculture production, a strong focus should be put on the improvement of postharvest and strategic storage in order to minimize losses and to continue to tackle malnutrition (MDG). USAID and WFP have offered to train on warehouse management and post-harvest management. Therefore, it is recommended that MINAGRI undertake analysis of potential consequences of Strategic Grain Reserve (e.g. different management approaches, fiscal implications, etc) as part of its design;

- The sector needs to sustain what has been achieved in term of production, market, postharvest and storage, and new technologies including mechanization. Therefore, it is 
recommended that a strategy be developed to see how those technologies developed by ISAR can be expanded and exploited by the private sector.

- The productions of coffee and tea have recorded low increases towards achieving EDPRS targets. Thus, it is recommended that MINAGRI conduct a mid-term evaluation of key EDPRS targets as well as a review of the targets for which performance has already been exceeded in preparation for the next forward looking JSR in which targets and actions can be revised;

- MINAGRI was also recommended to put in place a clear strategy for all development partners contributing to the sector development to ensure aid effectiveness and to allow DPs to move towards budget support, sector budget support or on-budget projects. Offbudget projects are very complicated and so coordination is very low for these. Therefore, externally-financed projects should be aligned to the budget and in concordance with government procedures including the financial year.

- For the institutional capacity building, care needs to be taken to ensure that MINAGRI and agencies are well-staffed (i.e. retention solutions), so that technical assistance has good counterparts. Therefore, it is recommended MINAGRI form a steering committee that can assess and prioritize the capacity needs for MINAGRI staff; advise on funds mobilization to fill those gaps, and to address the question of civil servant reform and retention. It is further recommended that those assessments be incorporated into MINAGRI plans for a better SWAp implementation.

- It was recommended that another sub-group was formed to assess the coffee fertilizer fund and put in place a strong mechanism for coffee fertilizer distribution. This group will be composed by IFAD, ISAR, OCIR-Cafe, USAID, IFDC and co-chaired by OCIR-Cafe and USAID. It was decided that once Private Sector has been brought on board, this group will meet and confirm a work plan, by the end of the month.

- It was recommended that the Food security sub-working group link with the nutritional sub-working group of the Ministry of Health and advise on how to tackle malnutrition issues. This sub-group will finish its work in the next 2 months.

- It was recommended that the rural finance sub-working group receive an additional time of 6 months in order to achieve their assignment especially related to financial literacy, skills and capacity building in this sector, at which time MINAGRI input into rural finance for Program 3 is mainstreamed into the Access to Finance Rwanda (AFR).

\subsection{ENVIRONMENT AND NATURAL RESOURCES SECTOR}

The Environment and Natural Resources (ENR) sector is diverse, encompassing the following sub-sectors (Environment, Lands, Water Resources Management Mines and Forestry.) and linked in a complex way to other sectors (health, agriculture, energy, tourism, housing, macroeconomic management, gender and social development, etc). In the environment sub-sector, the objective is to map, assess and rehabilitate critically degraded ecosystems as part of the Integrated Management of Critical Ecosystems. In the land sub-sector, the priority is to ensure a Land Tenure Reform Program aimed at improving and ensuring land tenure security for all citizens, but 
in particular to poor and vulnerable people, by putting in place an efficient, transparent and equitable system of land administration and land management. In the sub-sector of water resource management, the objective is to ensure rational and sustainable management of water resources for national socio-economic development. In the mining and geology sub-sector, the objective is to revamp the sector for increased mineral output and more than double the returns from mineral exports. In the forestry sub-sector the objective is sustainable management of forest and biomass resources.

The overall objective of the Sector is to develop sustainable capacities for effective advocacy, regulation and monitoring to ensure that environment and natural resources are utilised and managed productively in support of sustainable national development in line with the EDPRS targets and Vision 2020 aspirations.

In terms of progress on policy actions, 8 policy action targets; 5 (63\%) fully implemented and 3 (27\%) partially met. The sector had 6 corresponding targets, 4 fully implemented (67\%), 1 (17\%) partially implemented and 1 (17\%) not assessed.

In regard to the preparation of the National land Use and Development Master plan, aerial photography of $96 \%$ of Rwanda's territory was taken and high resolution ortho-photos and digital elevation model produced. Satellite imagery for the remaining $4 \%$ procured and are undergoing rectification. Planned sectoral studies completed and approved by Steering Committee, these have been used to develop alternative development scenarios. Consultation on these draft scenarios, suitability and needs assessment were carried out in May and June 2010.

Law establishing and organizing the real property valuation profession in Rwanda was Gazetted in May 2010. Members of the valuation board were appointed and the board put in place; Real estate valuers are in the process of forming an institute.

Water quality monitoring has been carried out on 36 selected points on water bodies and wastewater discharge points country wide. The report for all batches is being compiled. Also, 8 additional limn metric stations have been rehabilitated and now operational.

The key achievements which contributed to Forest resources management included 28 Districts forestry management plans finalized, Forestry law submitted to the MINIJUST for legal opinion and forestry Policy final draft produced.

Digitization of mineral map was produced in May 2010. Mineral deposit map by mineral element is available ( $\mathrm{Sn}, \mathrm{Nbta}, \mathrm{Au}$ and $\mathrm{W}$ ), Two studies of sand deposits are available( Masangano and Kirambo). The new Mining policy was approved by the Cabinet.

\section{Key issues}

- Lack of data caused by the weak system of data collection in Environment and natural resources. Where data exists, their credibility and quality are doubtful. The integrated water management department in Ex-MINIRENA has itself suffered from restructuring of the water sector in which water resources was separated from water supply and sanitation. 
- Lack of enough means (technology and space) for database creation. The split of the MINIRENA into MINELA and MINEFOM affects the functioning of OGMR as long as the budget is concerned a strong centralization disrupt the Agency activities.

- The rehabilitation of 5 hydrological and limn metric stations need to be expedited.

- Closer follow up of tree plantation exercise is required to assess why in some areas there is high percentage loss of trees planted. Overall losses amounted to close to $30 \%$ of the trees planted in 2008.

Table 1 Summary of Economic Cluster EDPRS Targets and Policy actions 2009/10

\begin{tabular}{|c|c|c|c|c|c|c|c|c|}
\hline & \multicolumn{8}{|c|}{ POLICY SCTIONS } \\
\hline Score Level & $\begin{array}{c}\text { Macro } \\
\& \\
\text { Financia } \\
\text { l }\end{array}$ & PSD & $\begin{array}{l}\text { Agricu } \\
\text { Iture }\end{array}$ & Energy & ICT & Transport & $\begin{array}{l}\text { Environment } \\
\text { \& Natural } \\
\text { resources }\end{array}$ & Total \\
\hline $\begin{array}{l}\text { Green (fully } \\
\text { met/on-track) }\end{array}$ & 7 & 3 & 8 & 3 & 2 & 2 & 5 & 30 \\
\hline $\begin{array}{l}\text { Yellow } \\
\text { (Partially met) }\end{array}$ & 2 & 2 & 2 & 0 & 0 & 2 & 3 & 11 \\
\hline Red (off track) & 0 & 0 & 0 & 0 & 0 & 0 & 0 & $\mathbf{0}$ \\
\hline Total & 9 & 5 & 10 & 3 & 2 & 4 & 8 & 41 \\
\hline & \multicolumn{8}{|c|}{ TARGETS } \\
\hline $\begin{array}{l}\text { Green (fully } \\
\text { met/on-track) }\end{array}$ & 5 & 4 & 6 & 2 & 2 & 2 & 4 & 25 \\
\hline $\begin{array}{l}\text { Yellow } \\
\text { (Partially met) }\end{array}$ & 1 & 1 & 0 & 0 & 0 & 0 & 1 & 3 \\
\hline Red (off track) & 0 & 0 & 0 & 0 & 0 & 0 & 0 & $\mathbf{0}$ \\
\hline N/A & $\mathbf{0}$ & $\mathbf{0}$ & $\mathbf{0}$ & $\mathbf{0}$ & $\mathbf{0}$ & $\mathbf{0}$ & 1 & 1 \\
\hline Total & 6 & 8 & 6 & 2 & 2 & 2 & 6 & 29 \\
\hline
\end{tabular}




\section{SOCIAL CLUSTER}

This cluster brings together Education, Health, Social Protection, Youth and Water and Sanitation sectors.

\subsection{HeALTH SECTOR}

14 policy action actions; 13 (92\%) fully implemented and 1(8\%) partially met. The sector was required to 11 indicators, of which 7 were fully implemented, and 4 not assessed.

The infant mortality rate (IMR) has decreased from 86 to 62 per 1,000 live births (2012 target is $62 / 1,000)$ and the under-5 mortality rate (U5MR) has decreased from 152 to 103 per 1,000 live births (I-DHS 2008).

The maternal mortality ratio has decreased from 750/100,000 live births (DHS 2005) to 383/100,000 live births in 2008 (Maternal Mortality for 181 countries, 1980-2008, a systematic analysis of progress towards MDGs, 2008).

The proportion of women continuing to use modern contraceptive methods among women in union is $53.6 \%$ and $29 \%$ among women of reproductive age (HMIS 2010). The percentage of women aged 15-49 years using modern contraceptive methods increased from $38.1 \%$ to $45.1 \%$ (HMIS 2009) from June 30th to 31st December 2009. The overall modern contraceptive proportion: $45 \%$ (HMIS 2010).

The case fatality rate of patients hospitalized with malaria has reduced to 3,5\% (HMIS 20092010). In 2009-2010 a total of 2,727,710 LLINs have been distributed countrywide: $1,566,559$ LLINs distributed to the under 5 children countrywide through $\mathrm{MCH}$ week campaign in April 2010, 352650 LLINs have been distributed through ANC services and data will be collected during the DHS 2010. 808,501 LLINs were distributed to the households, orphans, trainings and inpatients.

As Rwanda has now joined the EAC, it was necessary in July 2009 to harmonise it's planning and budget cycle with that of EAC. It was in this spirit that Health Sector Strategic Plan (HSSPII) has been developed for the period of June 2009 to July 2012.

The implementation of new tariffs establishing free Family Planning (FP) services to reduce the proportion of unmet FP needs started in the first semester of q1 for 2009/10. The EDPRS indicator for FP is to increase the use of modern contraceptives from $10 \%$ in 2005 to $70 \%$ by 2012. Currently, data from the HMIS show that the modern contraceptive utilization rate was $45.1 \%$ at the end of 2009 .

The percentage of assisted births in an accredited facility has significantly improved from a baseline to an estimated $63.5 \%$ in 2009 well above the targeted $40 \%$ for $2009 / 10$, already achieving the EDPRS target for 2012. The percentage of women aged 15-49 using modern contraceptive methods increased from a baseline of $10 \%$ in 2006 to an estimated $45 \%$ in 2009 , exceeding the target of $32 \%$ set for $2009 / 2010$. 
An integrated malaria elimination, pricing and distribution policy has been developed, which includes LLINS and ACT distribution and it has been adopted by all partners. It has also been published on TRAC Plus website.

A pricing and distribution policy and its strategic plan for long lasting ITNs and Artemisininbased combination therapy (ACT) to eliminate malaria throughout the country was finalized and will be published in April 2010. This policy aims at reducing malaria incidence in at-risk-groups by providing free ITNs to children under five.

"Pilot performance based financing was signed with association of community promoters which included key child health indicators into IMIHIGO". 416 cooperatives of community promoters cooperatives have had their statutes signed by the districts. Performance contracts at the district level have been signed with all steering committees of district hospitals.

Fully funding of family planning programs at US $\$ 0.3$ per capita per year from Government budget has been achieved. According to the Health Sector Budget 2009/2010, the per capita allocation to FP for individuals of reproductive age (males aged 15+ and females aged 15-49) is 0.41 for the recurrent budget which is above the set target.

Training in IMCI, which is a complete package of care for childhood illnesses, was conducted in 18 districts, namely: Kirehe, Ngoma, Ruhango, Nyanza, Gisagara, Nyaruguru, Nyamagabe, Nyamasheke, Ngororero, Musanze, Nyabihu, Rubavu, Burera, Bugesera, Gasabo,Rutsiro, Kicukiro and Nyarugenge. Such trainings will increase nutrition importance awareness hence reducing malnutrition.

Immunization coverage has increased to above $80 \%$ for all antigens by the end of 2009 . On the indicator measuring the percentage of children using Long Lasting Insecticide Treated Nets (LLITN), significant progress was made, reporting a score of $60 \%$ in 2008 from a baseline of $16 \%$ in 2006 . The utilization rate of primary health care services also increased from $70 \%$ to $86 \%$ in advance of the $80 \%$ target that was set for 2010 .

The policies for Health Insurance and community health insurance have been finalized and approved by the Cabinet. This approval by the Cabinet, paved away for the commissioning of the Law on Health Insurance and the draft is available. The submission of this Health Insurance Law has been delayed due to changes in Rwanda's Constitution and it has been re-drafted. This re-drafted Health Insurance Law, taking into account the Constitutional changes will be submitted to Cabinet for approval and then to the Parliament.

To Pilot reducing "ticket modérateur" and introducing conditional cash transfers for children under 5 and pregnant women. Pregnant women fulfilling 4 antenatal visits are exempted from paying "ticket moderateur". A pilot study on removing the 'Ticket moderateur' for under 5's is being conducted in Muhanga District (Muremure HC) and Kicukiro District (Gahanga HC). 
In order to increase the price of PBF for assisted deliveries by 50 percent and to implement in kind conditional cash transfers for assisted deliveries, PBF for assisted delivery is being increased to $50 \%$ in all health facilities from the 2009- 2010 budget. However, this process has been piloted in 4 districts starting in the second quarter of 2008-2009 in Nyamagabe, Rutsiro, Gakenke and Kirehe districts.

Table : Overall Budget Execution FY 2009/2010 Budget

\begin{tabular}{|l|l|l|r|}
\cline { 2 - 4 } \multicolumn{1}{c|}{} & $\begin{array}{l}\text { Allocation } \\
\text { (RWF) }\end{array}$ & $\begin{array}{l}\text { Execution } \\
\text { (RWF) }\end{array}$ & $\begin{array}{l}\text { \% } \\
\text { execution }\end{array}$ \\
\hline Total Budget & $55,211,215,504$ & $56,803,371,579$ & 103 \\
\hline Reccurent Budget & $43,624,418,722$ & $45,369,587,862$ & 104 \\
\hline $\begin{array}{l}\text { Development } \\
\text { Budget }\end{array}$ & $11,586,796,782$ & $11,433,783,717$ & 99 \\
\hline
\end{tabular}

\section{Key issues}

- There is a need mobilize and align necessary health sector financial resources to EDPRS and HSSP II programs and interventions;

- Reinforcing reproductive and FP programs for youth need to be strengthened;

- Men need to be more involved in family planning;

- Attracting and retaining qualified health personnel in public institutions, especially in rural areas need to be given special attention;

- Many health facilities managed by churches do not deliver modern contraceptive methods. This requires the establishment of a secondary health post in the vicinity of faith based Health Facilities hence more additional resources/budget required.

\subsection{WATER AND SANitATION SECTOR}

The overall objective of water and sanitation services is to ensure sustainable and affordable access to safe water supply, sanitation and waste management services for all Rwandans, as a contribution to poverty reduction, public health, economic development and environmental protection. In this regard, Rwanda has committed itself to reaching very ambitious targets in water supply and sanitation, with the vision to attain $100 \%$ service coverage by 2020 . The importance of adequate water supply and sanitation services as drivers for social and economic development, poverty reduction and public health is fully acknowledged in Rwanda's flagship policy documents and political goals.

6 policy actions set and 5 were completed and 1 was partially implemented. It had 2 indicators were fully implemented and 1 not assessed. 
In 2009/10, an estimated 7.62 million people equivalent to $76.2 \%$ Rwandans had access to safe drinking water supply within 500 Meters in rural areas and 200 Meters distance in urban areas. This is $2.2 \%$ increase compared to $74 \%$ access registered at the end of mid budget between January to June 2009. According to the EDPRS target, in 2012 , access to clean drinking water within $500 \mathrm{~m}$ in rural areas is $86 \%$.

In March 2010, the Ministry of Infrastructure (MININFRA) finalized with cabinet approval the updated Policy on Water Supply and Sanitation Services and Strategy with the objective of having a more output based policy framework for the accelerated development and the sound management of water supply and sanitation services, in line with the EDPRS, MDGs and Rwanda's Vision 2020.

9,175 ECOSAN latrines were constructed in schools. This is in line with the implementation of established Nine Years Primary Education Programme in Rwanda and increase the access of the population to sanitation facilities that meet hygienic conditions.

54 sensitization committees on Hygiene through PHAST and HAMS committees were setup in different Districts where they did not exist. The setup of these committees will mobilize the population to use and develop sanitation facilities in the communities.

\section{Key issues}

- The big challenge in the sub sector is to get appropriate data on the population with access to sanitation facilities especially at the house hold level.

- Coordination of all stakeholders in water supply including NGOs, INGOs, Associations, Churches and others is still a major problem.

\subsection{EDUCATION SECTOR}

The education sector will continue to contribute towards Rwanda's economic growth by making education more relevant for social and economic progress. This will be achieved by the establishment of a curriculum that imparts basic skills in traditional subjects, while also promoting social cohesion and making closer links between the content of education and the needs of the labour market.

12 major policy actions; 9 fully achieved and 1 partially implemented and 2 not implemented. It was supposed to implement 6 targets, 5 were fully implemented and 1 partially implemented.

In line with the EDPRS priorities, spending on education continues to be high. In the fiscal year 2009/2010, spending on education at about RWF 132 billion took a very large share of $19 \%$ of total outlays. Of this amount a large share went to the implementation of the Nine Year Basic Education policy.

Education Quality standards have been published and are being distributed to all users. The Girls' Education Strategic Plan has also been validated with all stakeholders; and the Girls' Education Policy disseminated at District level. 
The 9 year basic education was successfully implemented for the first year to scale-up access to education. About 3,140 new classrooms were constructed to provide space for 9YBE and equipped with 74,046 desks. 765 schools are now offering 9YBE, 522 of which are new. In addition 9,175 latrines were constructed in various schools to improve hygiene.

Primary Gross Enrolment Rate (GER) has declined from 128\% (2009) to 127\% (2010) and GER for boys (125\%) is lower than for girls (128\%). Primary Net Enrolment Rates (NER) has increased from $93 \%$ (2009) to $95 \%$ (2010) and NER for girls (97\%) is higher than for boys (94\%). Primary Completion Rates increased from $74.5 \%$ in 2009 to $75.6 \%$ in 2010. Girls' primary completion $(79.8 \%)$ is markedly greater than for boys $(71.4 \%)$. The total number of pupils in primary education increased marginally (by 34,654 pupils) and now stands at 2,299,326 million. The number of students in lower primary continues to increase as a result of 9YBE, a further 63,685 were added in 2010 to give a total of 298,212 (2010). The transition rate from primary to secondary education increased from $88 \%$ in 2008 to $95 \%$ in 2009 . The promotion rate within primary education increased from $69.5 \%$ (2008) to $73.8 \%$ (2009) with the rate for girls marginally higher than for boys. This shows that both the repetition (14\%) and dropout rates $(12.2 \%)$ have both reduced.

Science practical materials were distributed to different science centers and practical exams were held for the first time in secondary school across the country. More so, Technical and Vocational Training were given more attention as 100 trainers were trained in Singapore and Philippines while 316 teachers were trained locally in vocational training. Kicukiro Polytechnic was reconstructed while other Integrated Polytechnic Regional Centres were given equipments.

In upper secondary education, the Ministry has developed and provided a good number of infrastructures in various schools, colleges of education, TVET and Higher Learning Institutions. This has allowed for the very first time to organize and successfully conduct practical sciences examinations in secondary education.

About 40,008 teachers were trained in English language, this fiscal year, tenable schools to use English as the language of instruction and all Mathematics and Sciences teachers were given special training sessions due to the specific nature of their subject. About 1,624,000 textbooks in English were provided to the 9 year basic education and 320,000 textbooks for secondary education.

Setting up the Directorate General of Science \& Technology, Research and Innovation, in the Ministry of Education has led the transfer of the responsibility for Science \&Technology, Research and Innovation from the Office of the President to the Ministry of Education in July 2009. This has been an important factor for supporting the area of research.

5 year costed strategy and operational plans of the education sector and that of individual HLIs terms of reference in place; strategic plan completed. 


\section{Key issues}

- Though the Ministry of Education is one of the Ministries to get an important portion from the total budget of the country, the uniqueness and importance of activities that were planned for at national level has made it impossible to operate within the allocated budget. Therefore, most institutions under the Ministry were given a small portion of their required budget and were requested to try to cope with or where applicable encouraged to generate income to top up this budget;

- Being a lead Ministry of the Education sector, the Ministry of Education should be the apex of the best and highly qualified staff. Unfortunately, over the reporting period, the staff turnover has tremendously increased especially in High Education. This was due to low salary index and lack of motivation/ retention scheme in the Ministry and its institutions. Consequently, the Ministry still relies on Expatriate staff to teach in High Schools and carry out research.

- In most institutions and research centre, library and ICT facilities are still insufficient and inadequate. To this problem comes also the lack of facilities to accommodate students.

- Over the reporting period, it was realized that the majority many Rwandans still have a negative perception on TVET. In fact, a good number of students allocated in TVET institutions are reluctant to join them.

\subsection{Social Protection Sector}

The social protection sector contributes towards the Economic Development and Poverty Reduction Strategy by (EDPRS) providing effective social safety nets and integrated social protection programming; with a focus on combating extreme poverty. A wide range of institutions contribute towards achieving the short term and long term objectives of the sector both governmental and non-state - are active in social protection. MINALOC has the overall policy lead; it heads a cross-governmental Social Protection Working Group, which includes representatives from Ministries working on social protection, key parastatals, development partners and NGOs.

In terms of progress on policy actions, 9 policy action targets; 5 fully implemented (56\%) and 2 partially met (22\%) and 2 not implemented (22\%). The sector had planned to achieve 5 targets. 3 were fully implemented and 2 not assessed.

Vision 2020 Umurenge program is currently operational in 60 sectors and the budget for that was committed for this fiscal year was Rwf 14851720721 which reflected the EDPRS priorities of Public Works with Rwf 8755477 503; Direct Support Rwf 1414018811 and Financial Services of Rwf 4682224 407. This program has assisted in ensuring the coordination of all social protection activities, in accordance with National Social Protection Policy.

Monitoring of market wage rate data (collected at cell level and reported at sector level) was initiated in November 2009. This is planned to be a quarterly exercise. In the majority of cases the VUP public works wage rate was no higher than the market wage at the sector level where the program is being implemented, although exceptions were apparent. 
The microfinance component has gone through a process of redesign during the reporting period. A policy decision has been made to use the Ubudehe Credit Scheme which started in February/March 2010 in the 60 sectors. Under this, about 54,921 persons were organised into 4,291 Production groups/tontines of 41,332 persons; 156 Cooperatives of 3,588 persons; and 10.053 individual persons. On average each person received rwf 81.130.

The VUP program has been successfully scaled up to 60 sectors exceeding the targets. Of the households eligible for support, the percentage granted public works was targeted at $35 \%$ which was fully realized. The percentage of households eligible for support and granted direct support in VUP sectors has reached $100 \%$ exceeding the target.

\section{Key issues}

- The absence of a sector strategy has made it hard for some stakeholders to contribute effectively the overall performance of the sector. The Strategy that is being prepared sets out to address this challenge.

- Donor co-ordination on social protection has improved in recent years, but there is still further room for improvement. Government needs to ensure that donors get behind government priorities, as set out in this Strategy.

- Similarly, there is a need to build greater coherence among the many programmes implemented by non-state actors and ensure that they are aligned to national priorities.

\subsection{Youth Sector}

2 policy targets; both partially implemented.

In regard to strengthening District wide youth savings and credit schemes, only 2 branches (Bugesera and Remera) were financially supported compared to a target of starting up 8 COOJAD branches. This is was mainly due to budget constraint.

By June 2010, about 40 youth associations will have been supported and transformed into cooperatives. Currently, 33 Associations have been identified, 13 have been supported to transform into cooperatives and ten (10) of these have been funded.

\section{Key issue}

- The mobilization of youth to transform their associations into cooperatives is being hampered by a set of issues including: inexistence of the culture of cooperation among youth, the desire for quick wins among youth, lack of skills and capacity to translate theory into action and limited ability to design viable projects for them to start processing loans, and limited managerial capacity among cooperatives leaders.

- A decision to channel government support through a youth window that has to be established under Umurenge Sacco was reached and that COOJAD would be phased out. 
- Limited capacity of National Youth Council structures to carry out effective implementation and monitoring of youth development programs

- Limited capacity of youth to adopt innovative and new ideas (especially those with limited or no schooling) that would increase benefits of their activities;

- Enhancing monitoring and evaluation of youth programs.

Summary of Social Sector EDPRS Targets and Policy actions 2009/10

\begin{tabular}{|l|c|c|c|c|c|c|}
\hline \multicolumn{7}{|l|}{ POLICY ACTIONS } \\
\hline Score Level & Education & Health & $\begin{array}{c}\text { Social } \\
\text { Protection }\end{array}$ & $\begin{array}{c}\text { Water and } \\
\text { Sanitation }\end{array}$ & Youth & Total \\
\hline $\begin{array}{l}\text { Green (fully met/on- } \\
\text { track) }\end{array}$ & 9 & 13 & 5 & 5 & 0 & $\mathbf{3 2}$ \\
\hline Yellow (Partially met) & 1 & 1 & 2 & 1 & 2 & $\mathbf{7}$ \\
\hline Red (off track) & 2 & 0 & 2 & 0 & 0 & $\mathbf{4}$ \\
\hline Total & $\mathbf{1 2}$ & $\mathbf{1 4}$ & $\mathbf{9}$ & $\mathbf{6}$ & $\mathbf{2}$ & $\mathbf{4 3}$ \\
\hline & & & & & & \\
\hline
\end{tabular}

\section{Governance Cluster}

The governance cluster brings together four sector working groups related to the areas of Public Financial Management (PFM), Justice, Reconciliation, Law and Order (JRLO), Decentralization, Citizen Participation, Empowerment, Transparency and Accountability (DCPETA), and Capacity Building and Employment Promotion (CBEP). 


\subsection{Capacity Building and Employment Promotion Sector}

The Objectives of the Capacity Building and Employment Promotion Sector with respect to the Vision 2020 and EDPRS is to strengthen Public Sector Capacity in order to provide effective and efficient Service Delivery and put in place initiatives to enable increased levels of decent and economically productive employment. Both of these are essential for supporting economic development in Rwanda. In EDPRS framework, the CBEP sector will provide support to enhance the institutional, organizational and Human Capacity of Public Institutions at all levels of Governance in order to ensure that there are gainful improvements in Service Delivery.

4 major policy targets; 1 fully implemented and 2 partially achieved and 2 not achieved. The sector was also supposed to implement 3 indicators, 1 were fully implemented and 2 not assessed.

\section{Index of effectiveness of payroll controls:}

- The IPPIS Phase I -Payroll Module (Subsystem) accomplished,

- The IPPIS Phase I-Human Resource Modules accomplished,

- The HR and payroll subsystem developed,

- The IPPIS Business processes documentation developed

- The Integrated Personnel and Payroll Information System(IPPIS) Documentation Accomplished

- IPPIS User Groups trained

The Internship Programme for new Graduates from different Rwanda Universities was launched with 100 internees selected, and of these 100 people, 77 persons are now hosted within the Internship Programs. 271 Internees started the second phase of internship program in March 2010. The Internship Programme for new Graduates from different Rwanda Universities and out side Rwanda was launched in March 2010.

The Ministry of Public Service and Labour appointed a Team on 2/02/2010 composed of WDA, PSF, National Labour Council, RDB and MIFOTRA with a mandate to elaborate and finalize the law establishing the National Employment Agency. However, the Kivu Retreat (19 - 22 February 2010) resolved that there was no need to create this Agency, instead directed that the activities that were being performed by Labour and Employment Department under MIFOTRA be transferred to RDB. 
Overall Budget Execution Financial Year 2009/10 Budget

\begin{tabular}{|l|c|c|c|}
\hline & Allocation (RWF) & Execution (RWF) & \% Execution \\
\hline Total Budget & $6,702,820,462$ & $5,388,597,169$ & $80 \%$ \\
\hline Recurrent Budget & $3,475,043,103$ & $2,767,146,808$ & $80 \%$ \\
\hline $\begin{array}{l}\text { Development } \\
\text { Budget }\end{array}$ & $3,227,777,359$ & $2,621,450,361$ & $81 \%$ \\
\hline
\end{tabular}

Basing on the table above the Ministry executed its budget by $80 \%$ which shows under spending of $20 \%$. Some of the reasons of this under spending are:

1. The construction of RIAM-Muhanga branch was stopped due to disagreement between Construction Company and Supervision Company on the quality of materials used in construction. This resulted into making quality testing for those materials in Belgium. Another Building in Kigali was stopped by MVK due to uncompleted construction documents.

2. Manpower survey which was to be carried out by the Rwanda Institute of Statistics was done due other urgent surveys that the Institute was requested to do at the same.

\section{Key issues}

- Lack of statistical data and baselines to define clear target for Capacity Building and Employment Promotion sector;

- Lack of planning to well coordinate the Sector Working Group interventions;

- Inexistence of strategy to implement effective and efficiency of the internship program;

- Inability to capture full spending on capacity building at national level;

\subsection{Decentralization, Citizen Participation, Empowerment, Transparency and ACCOUntability (DCPETA) SECTOR}

Decentralization Citizen Participation, Empowerment, Transparency and Accountability Sector contributes to EDPRS strategic objective of Enhanced gains through good governance that can be realized in strategic outcomes of Enhanced partnership between GoR, Civil Society and Private Sector, Enhanced Local Governments Capacity, Enhanced Citizen participation in decision making and Improved public accountability. 
5 major policy actions; 4 fully implemented and 1 not implemented with all 3 corresponding targets fully implemented.

The targeted percentage of strengthen local government capacities to improve access to quality services, sustain socio-economic development, manage and coordinate sector strategies was $65 \%$ in 2009/10 and according to the monitoring \& evaluation the implementation 2009/2010 Imihigo exercise carried out in June 2010 that covered all 30 districts, $67.2 \%$ is the average score but the best district got $79.3 \%$. Nyamasheke emerged the best district. This time around the ranking was quite peculiar and transparent where districts were ranked from the first to the last.

A Citizen Report and Community Score Card exercise is another key achievement in the sector. This citizen Report and community score card was conducted and validated in March 2010. This assisted in assessing capacity (institutional, organizational, and operational) at all levels in order to strengthen and improve access to quality services and sustain socio-economic development. The Joint Governance Assessment and results indicated that about $86 \%$ of the population was happy with service delivery while $72 \%$ of the population rated Local Government Accountability and responsiveness of local leaders as very good.

Progress in the Itorero program exceeded the training target of at least 70'000 people by training 87505. Awakening patriotism and promoting the common good and working progressively through Itorero ry'Igihugu, so far a total of 157,241 people have gone through Itorero since its inception; these include cell leaders, teachers, sector executive secretaries, Rwandan youth in the Diaspora, Agricultural stakeholders, health stakeholders, youth living in Rwanda, trainers of women, community policing committees, disabled and cooperatives leaders.

NURC has developed a tool that will always be used to measure the Nation's status in line with Unity and Reconciliation (Rwanda Reconciliation Barometer). Other implications of this ongoing research: Rwandans will be asked their level of satisfaction with government institutions among them are the local authorities. In this line, the citizens' level of satisfaction with local authorities can have an implication on their level of participation in decision making. The contribution of Itorero ry'Igihugu in the entire policy of Unity and Reconciliation will also be analyzed in this ongoing research.

To strengthen democratic organizational culture and ensuring transparency and accountability in public/private sectors and civil society, the following key programs were implemented to increase citizens expressing trust and confidence in government:

The Electoral Code for the 2010 elections was drafted and approved by the Cabinet.

$\checkmark$ Draft law on Charter on democracy on election was passed.

The electoral code was drafted and was approved by the cabinet ;

The National Electoral Commission organized bi-elections in districts of Burera, Huye, Nyanza, Ruhango and Kigali City; to replace the Mayors and Vice Mayors. 
$\checkmark$ MINALOC in collaboration with other Government institutions, Private Sector and Civil Society Organizations developed an Integrated Governance Action Plan (IGAP).

There was substantial progress on the follow-up of the recommendations from the previous JSR with the majority of the recommendations being implemented. More progress needs to be registered in terms of the approval and implementation of the new Common Development Fund (CDF) structure (Rwanda Local Development Support Fund, RLDSF) and sufficient staffing, establishing a basket fund for the delivery of capacity-building to local governments and the redefinition of the scope of the SWG.

\section{Key issues}

- Joint Action Development Forum (JADF) plays a pivotal role in local economic development and harmonization of stakeholders' interventions and therefore requires a close follow up.

- Interventions by different stakeholders in the sector need a proper coordination and communication system to avoid duplication of efforts. Hence a need for harmonization of donor intervention.

- Need to have ambitious but realistic targets to avoid budget constraints like those MINALOC had on funding Itorero program.

- Civil society involvement in the matters concerning the sector working ground has been on a limited scale yet they play a fundamental role in their oversight function.

- Local government capacities both human and financial still remain a challenge and regarded as areas of concern in the sector.

- Continuous restructuring and time spent on this exercise creates a gap in the actual implementation and service delivery.

- Un harmonized planning and budgeting at central and sub-national levels used to hinder proper implementation of decentralization program. There is urgent need to redress this situation.

\subsection{JUSTICE, RECONCILIATION, LAW AND ORDER SECTOR .}

19 major EDPRS policy actions, of which 12 were fully achieved, 5 partially implemented, and 2 were not achieved. Out of 6 indicator the sector had planned to implement, 4 targets are in green; 1 is in yellow and 1 in red.

1 policy action (Karongi Production Centre) had lost its relevance for the sector.

Justice, Reconciliation Law and Order Sector was adopted by the Cabinet decision $n^{\circ} 4$ of 16 th December 2009. The Ministry of Justice, the Supreme Court, the NPPA and the Police carried out trainings on members of different committees covering security, reconciliation, and justice 
issues on district level. The Minister's instruction on the mandate, objectives, and tasks of the JRLOS Technical committees were discussed in the JRLOS TWG. Here it was stated that there are already different committees active on the district level coordinating security and justice as well as reconciliation issues. These are the security committees on district level, and the Justice Committees on the level of intermediary courts. The TWG proposed to carry out a mapping of committees on district level, and to clearly determine the focus of the different existing committees, and especially the needs of the population to determine the necessity for a further committee.

The NPPA continues the sensitization campaigns on the fight against corruption and the popularization of laws on corruption and accountability through the media (written press, radio and television). Regular contact meetings are organized between the BNR, Financial Institutions, Donors (GTZ) and the CID, the Auditor General of Finances and NPPA.

The Commercial court structure is established and operational. The administrative structure for commercial courts is set up. Physical infrastructure is in place (offices, furniture, IT equipment). Capacity building: Several judges are being trained including 7 judges completed master's degree in commercial law in South Africa in July 2009, 3 judges are completing master's degree in commercial before December 2010, 5 more judges were send to SA in July 2010 to pursue Master's Degrees.

The NPPA continues the collaboration with RNP, MINIJUST, and the Ombudsman on corruption cases and the sensitization of the public on their civic rights.

163 cases of corruption were entered at the NPPA out of which 106 were processed (transmitted to jurisdictions or dismissed), for 57 cases the investigation is still going on.

The NPPA has adopted its new Organic Frame (Organigramme) and the specialized unit pursuing economic and financial crimes is incorporated. The specialized unit (with 2 inspectors) is operational and investigates corruption and embezzlement cases reported by the Auditor General

The expansion of Butare prison continues. The installation of biogas plants and water is done while the construction of the outer fence and toilets is done for $90 \%$.

Ministry of Justice in cooperation with UNICEF will employ one extra staff per MAJ to only observe the treatment of minors by the police and judicial authorities and assist them. Furthermore a task force under the lead of MINIJUST including, the prosecution, police, and local authorities is being established to determine the situation of minors in conflict with the law, and to establish a baseline according to the indicator. The legal aid week organized and executed by MINIJUST in cooperation with several NGOs and the KBA concentrated on the assistance to minors. 
The expropriation exercise at Butamwa and Gikombe is stands now at $80 \%$. Construction of Gikombe prison has been given top priority and has started. Completion of construction deadline has been set at 6 months.

\section{Budget execution}

$\begin{array}{llll} & \text { Allocation } & \text { Execution } & \% \\ \text { Total Budget } & 42.079,17 & 39.595,60 & 94,10 \% \\ \text { Recurrent Budget } & 36.202,42 & 34.820,43 & 96,18 \% \\ \text { Development Budget } & 5.876,75 & 4.775,16 & 81,26 \%\end{array}$

Low execution is explained by procurement delays in the implementation of sector studies. Also, as the Law Reform Commission and ICTR Representation were not operating, a part of their budget was transferred to Gacaca.

\section{Key challenges}

- One of the key challenges in the JRLO Sector remains the increasing influx of new cases to the courts. The risk that the back log will worsen is high, due to increasing land disputes. The sector has established a task force including the police, the NPPA, and the courts to establish scenarios to improve the treatment of disputes on the lowest possible level. The increased training of Abunzi will also assist in a potential solution.

- The established Task Force focusing on the treatment of minors in conflict with the law will establish a first baseline concerning the quantity of juveniles in detention, their treatment, and the time spent in detention. This task force will come up with proposals to improve the treatment of minors. Furthermore the legal aid week will again focus on the assistance to minors.

- The establishment of fully fletched forensic laboratory including DNA analysis for the police represents a serious budgeting challenge. A deeper analysis of the present study for the establishment of a forensic laboratory including DNA analysis revealed that the investment cost would absorb approximately $50 \%$ of the present budget for the police. The future incurred recurrent cost for such a laboratory would also be too high relative to the existing budget for the police. Therefore a taskforce was established, including the RNP, NPPA, the JSCS, and BTC to carry out a further study to properly establish the quantitative and qualitative demand/need for forensic analysis for the detection of crime.

- Unfortunately the present definition by MINECOFIN of the JRLO sector has not changed. This discrepancy between the MINECOFIN classification and the JRLOS definition is 
explained by the fact that MINECOFIN includes the 'Property and Services Security' programme containing four specific security services depending directly on the President's Office and excludes the NURC and Ombudsman's Office. Also the 'Risks and disaster management' programme of the Rwanda National Police is excluded from the MINECOFIN classification whereas the following three programmes are included (and are not part of the JRLOS): MINALOC Security sub programme (in 'Local administration programme), Districts Abunzi programme, and MINIJUST's sub programme 'Representation of Rwanda with the ICTR in Arusha'.

- Cross-cutting issues need to be given more attention.

\subsection{Public Finance Management (PFM) Sector}

The ultimate goal of the Government of Rwanda PFM Reform Strategy [2008-2012] is to ensure efficient, effective and accountable use of public resources as a basis for economic development and poverty eradication through improved service delivery. The strategy focuses on building human resource capacity, putting in place modern and effective systems and procedures for effective financial management and reporting, and strengthening the institutional framework in accordance with international best practices for a more efficient and transparent PFM system. It also aims at increasing effective coordination of various reforms, sequencing the reforms to the priorities of the country consistent with both the Economic Development and Poverty Reduction Strategy (EDPRS) and the Vision 2020, and to ensure effective implementation.

During 2009/2010 PFM had 11 (eleven) major policy actions and as per the analysis in this performance report 8 policy targets were fully implemented, 2 were partially achieved and 1 (one) was not achieved. This status shows that the overall implementation of the policy targets is quite satisfactory. The 2 policy targets that are not fully implemented are mainly due to the unforeseen delayed timing of the initiation of underlying activities and both of these policy targets have been carried forward to 2010/2011. 6 indicators were planned, 4 were fully implemented and 2 partially implemented.

- In order to improve on the quality and timeliness of annual financial statements, $40 \%$ of all budget agencies were to submit their internal audit reports in 2009/10. This target was exceeded as $45 \%$ of all budget agencies submitted their internal audit reports in 2009/10 financial year.

- Revitalize MTEF and integrate it into the budget process- The MTEF is fully developed and integrated into the budget process. However further enhancement of the framework and integration process is planned to be undertaken during 2010/2011 in addition to comprehensive sensitisation and training.

- Improve budget structure and classification to align with the GFS 2001 throughout Government - This activity is scheduled to be concluded in the second quarter of 2010/2011 
under the ongoing PwC capacity building contract. Substantial progress had been achieved by the end of the 2009/2010 fiscal year with the contractual process concluded and data collection and validation in progress.

- Conduct training for short term skills enhancement courses and ACCA Course: Capacity building for financial and accounting staff is on course being provided through onthe-job training, annual reinforcement trainings and sponsorship of ACCA professional training for staff with financial management responsibilities. 92 students were enrolled for the June 2010 sitting and achieved an average pass rate of 57\%. Currently 265 students are enrolled for the December 2010 sitting.

In order to boost the chances of attaining high pass rates, an ACCA specialized training institution was contracted to carry out training within Kigali with effect from March 2010. Additionally two full time ACCA training coordinators were recruited in the Accountant General's office and an ACCA training committee has been set up to handle emerging training program administration, student performance and policy issues.

- IFMIS piloted in key CG ministries- On $1^{\text {st }}$ July 2010, following a short piloting phase between April and June 2010, the core modules of the IFMIS were rolled out to 94 out of 236 budget agencies. Current efforts are focused on providing sufficient end user support, developing key functionalities that enhance the performance and controls embedded in the business processes of the core modules, and developing operational and management reports for end users. The IFMIS will be rolled out to the rest of the budget agencies in two additional phases.

- Build Capacity for conducting Risk Based Systems Audits - On-the-job training covering value for money, payroll audits and use of computer aided audit techniques using a training of trainers approach is ongoing within the office of the GCIA.

- Develop and adopt proposals for the implementation of audit committees- This was fully achieved and the legislation (ministerial order) for the implementation of audit committees is in place. Currently, Audit Committees are operational in 13 out of 17 GBEs. Next steps will involve appointment of Audit Committees for 5 Ministries including MINECOFIN by October 2010.

- Implement and monitor the government portfolio management strategy -The government portfolio strategy was prepared, approved and is under implementation. A fully fledged Government Portfolio Unit was set up in MINECOFIN and on-the-job training for the Unit's staff was carried out by $\mathrm{PwC}$ in March 2010. A fiscal risk review report for all GBEs was prepared by the Unit in June 2010.

\section{Key Challenges}

a) Low levels of PFM capacity at Central Government, Districts, Provinces and facilities such as hospitals, schools and prisons- This challenge is being addressed by ensuring that adequate human resources are availed to all Government entities, undertaking institutional restructuring and by carrying out continuous capacity building programs. 
b) Complexity of automating financial management procedures- Efforts to address this challenge are currently focused on developing a "Blue Print" for the IFMIS implementation, enhancing the core functionality of SmartGov and designing interfaces with other systems such as IPPS, BNR and RRA systems.

c) Staffing of the PFM Secretariat: The inauguration of the PFM Basket Fund during the year has significantly increased the number of procurement activities to be undertaken and this challenge will be addressed via the recruitment of a 2nd Procurement Specialist.

Table 3 Summary of Governance Cluster EDPRS Targets and policy actions 2009/10

\begin{tabular}{|l|c|c|c|c|c|}
\hline \multicolumn{7}{|c|}{ POLICY ACTIONS } \\
\hline Score Level & PFM & JRLO & DCPETA & CBEP & Total \\
\hline Green (fully met/on-track) & 8 & 12 & 4 & 1 & \\
\hline Yellow (Partially met) & 2 & 5 & 1 & 2 & \\
\hline Red (off track) & 1 & 2 & 0 & 2 & \\
\hline Total & $\mathbf{1 1}$ & $\mathbf{1 9}$ & $\mathbf{5}$ & $\mathbf{5}$ & \\
\hline & \multicolumn{7}{|c|}{ TARGETS } & & \\
\hline & & & & & \\
\hline Green (fully met/on-track) & 4 & 4 & 3 & 1 & $\mathbf{1 2}$ \\
\hline Yellow (Partially met) & 2 & 1 & 0 & 0 & $\mathbf{2}$ \\
\hline Red (off track) & 0 & 1 & 0 & 0 & $\mathbf{2}$ \\
\hline N/A & 0 & 0 & 0 & 2 & $\mathbf{1 9}$ \\
\hline Total & $\mathbf{6}$ & 6 & $\mathbf{3}$ & $\mathbf{3}$ & \\
\hline
\end{tabular}

\section{DISTRICT IMIHIGO EVALUATION FOR 2009/10}

Since 2006 when the District leadership started signing Imihigo with His Excellency, The President of the Republic of Rwanda, evaluation focused on the 10 best performing Districts based on the evaluations carried out by Provinces and Kigali City. These evaluations identified the top 2 performers from each of the 4 Provinces and Kigali City. However, concerns relating to this approach of evaluation were raised especially since it was not viewed as being comprehensive enough. This approach also required a second evaluation phase for the top 10 performers which was not harmonized with the first phase conducted by the Province or Kigali City leading to possibilities of duplication or discrepancies. It was on that basis that that the 
evaluation exercise for the 2009-10 Imihigo was comprehensive by extending to all 30 Districts using a uniform and harmonized methodology for purposes of identifying the best performing Districts nation-wide. This revised approach helped to identify the key challenges faced and these challenges were addressed in the design and implementation of the 2010-11 Imihigo.

\subsection{KEY ACHIEVEMENTS REALIZED BY DISTRICTS}

On the whole, the concept of Imigiho as a development strategy has led to promising results by promoting a competitive spirit and creating focused and enthusiastic effort which are essential components to the long awaited development. In addition, the strategy has promoted an effective mechanism of monitoring and evaluation of development initiatives, which is essential to promote focused development. The following are key achievements realized:

- SACCOs; Good progress has been made in mobilizing citizens to join SACCOs and reasonable funds have been mobilized. Although most of the SACCOs have obtained provisional licenses from BNR to operate as savings and credit cooperatives, they still need to mobilize more member subscriptions in order to realize the minimum amount required to obtain full licenses. Most of all SACCO UMURENGE need adequate offices.

- 9YBE; all Districts evaluated have made substantive progress in classroom construction. The exercise is yet to be completed given that almost all pit latrines are still under construction with some at foundational level.

- VUP; the three programs implemented under VUP have substantially improved the welfare of citizens as well as facilitating the implementation of government policies such as SACCO, Terracing, road construction, etc

- Land use consolidation; through use of programs such as public works, TIG and one village one product program, selected crops such as wheat, irish potatoes, coffee, tea, beans, etc have been cultivated extensively.

- Infrastructural activities (such as roads and health centres); most rural and town roads are in good conditions. Of these, some are newly constructed while the others rehabilitated. Good health statistics such as those of maternal and child mortality, accessibility of maternal and child care, and accessibility to health insurance (Mutuelle de Santé) reveal improved levels of health care for the population.

- Small scale factories; there was evidence in most Districts of initiating small scale factories most especially those involved in agro-based products. 


\subsection{CHALLENGES/LESSONS LEARNT}

The key challenges that were observed during the exercise of evaluating the 2009/2010 District Imihigo were the following:

- Unrealistic and overambitious targets, e.g., to achieve $100 \%$ by fighting corruption and conflicts between employees, and setting targets without consideration of available and potential resources to achieve them;

- Planning gaps still exist in Districts - activities, indicators, baselines and targets were found not to be logical and consistent. This made it difficult and often impossible to measure progress made and consequential impacts on development; Unclear and often confusing baselines and targets made it difficult to measure progress made;

- There was general lack of progress reports on activities implemented. Regular assessment and evaluation especially on key activities being undertaken should be made to address this challenge. This will also help Districts to build reliable databases and baselines in Imihigo;

- It was difficult to measure the role played by development partners vis $\bar{a}$ vis the contributions by Districts. Activities undertaken by Districts in such endeavors should be clearly spelled out in order to measure their specific contributions to development;

- It was mentioned that the exercise of designing performance contracts/Imihigo was often influenced by activities/targets raised by various government institutions including ministries and yet most of the activities lacked funding. It is important to strengthen dialogue and coordination between the line ministries and Districts to ensure that targets are in harmony with funds or resources committed by the Ministries.

\subsection{THE WAY FORWARD}

\subsubsection{QUALITY ASSURANCE TEAM}

The challenges encountered pointed to lack of quality assurance services at the different stages of imihigo designing and formulation. The quality assurance team was established and was tasked to regular engagement with District and Province leaders at different stages of Imihigo preparation in order to ensure that the Imihigo adequately reflected in the national priorities.

\subsubsection{LINK BETWEEN IMIHIGO AND DEVELOPMENT STRATEGIES SUCH AS EDPRS, MDGS,} DDP, MTEF, DAP

Imihigo should not be planned (designed, formulated and implemented) in isolation without drawing from existing plans or development strategies. Thus, there is need to link Imihigo with broader objectives of development strategies mentioned above. Imihigo and existing development strategies have got to feed into each other to ensure a coherent development path. 


\section{INTEGRATION OF CROSS-CUTTING ISSUES:}

\subsection{CONCERNING GENDER}

Guidelines for gender-based budgeting have been developed and Gender budget statements have been produced for budget submissions of the 2010/2011 fiscal year in 4 pilot sectors: Agriculture, Health, Infrastructures and Education.

In Gender monitoring and evaluation, the EDPRS stakeholders' commitments on gender mainstreaming including GMO, National Development Planning and the NISR recommended that all surveys and publication have to be engendered through improved gender disaggregated Data collection and use for effective monitoring and accountability.

The Revised National gender policy and its strategic plan were adopted while the Gender Profile 2005-2007 at the sector level was disseminated.

In the Agriculture sector, MINAGRI is currently in the process of drafting its gender strategy, which will further guide the Ministry in taking both men and women's needs into account in service provision. Particular areas of focus of the strategy include ensuring women benefit from crop intensification and land consolidation, from export crop production as well as from the livestock sector.

In justice sector: there are now almost $40 \%$ of female judges and women occupy $22 \%$ of leadership positions. The gender based violence and labor laws were disseminated in the public and especially to women. During the FY 09/10 the NPPA further strengthened access to justice for victims of gender-based violence. A toll-free telephone hotline (3677) was installed in 2009 offering information to a steadily increasing number of users, which is an indicator that awareness raising campaigns conducted by NPPA during the last year (theatre in schools, TV production, radio emissions) were fruitful.

National Police Services (NPS) have mainstreamed Gender in their programs and administration. In NPS $37.50 \%$ of women is in Leadership positions. In RNP recruitment, women are encouraged to apply and are sensitised to join security institutions. The Gender Based Violence desk has been established and is operational.

In Education, the Girls' Education Strategic plan for the implementation of the Girls' Education Policy was validated and that Policy disseminated at the district level. This forms the framework for interventions to increase girl's participation and achieve education of all and universal primary education (MDG 2). In term of access, gender parity has already been achieved since 2001 and in 2008; the net enrolment rate for girls (95.1\%) in primary schools was slightly higher than boys (93.3\%). The Latest statistics for 2009/2010 also shows a higher completion rate for girls $(78 \%)$ than boys (71\%). However, gender imbalance in retention and transition still persists at secondary and tertiary levels of education with $33 \%$ of females in public universities. In term of performance, boys consistently outperform girls in national exams, even though more girls than boys sit the exams. There is a greater synergy in performance in languages but in maths and science, the average marks for boys are higher. Participation by girls in science courses is lower than boys and much lower in technical subjects such as Electrics, Automobile Mechanics, and Construction. It is almost equal in Computing but participation is still higher in subject traditionally associated with females such as Accounting and Secretariat. The challenges include traditionally attitudes and work demands at home along with health and sanitation issues which impact on girls' attendance and self-esteem.

In response to the issue of quality school environment and ensuring girls' access, retention and successful performance, the General Inspectorate of Rwanda developed Standards for improving Education Quality to enhance and improve quality in schools and these standards generally include;

- Enrolment, retention, performance and completion of both girls and boys; 
- $\quad$ Teaching and learning processes;

- School environment (physical and psycho-social);

- School management and Parental involvement;

- Special Initiatives.

Also, 12 primary Schools and 12 secondary best performing schools in promoting Girls Education were awarded at National level;

In Energy sector: Gender situation analysis was conducted in the energy subsector as the most relevant to gender issue such difficult to access energy for cooking. Due to gender roles and division of labour, women are more concerned with the issue of energy at household level. Therefore, women spend more time in collecting firewood and cannot have enough time to do other activities such as income generation that can improve their lives. Women are more involved in food preparation and poor energy and house conditions affect their health because of indoor air pollution.

In the Women empowerment program, the restructuring of women credit fund is going on and the women credit funds financial audit was conducted in Kigali City, Eastern, Western and Southern Provinces. About 640 Women were trained on entrepreneurship in all Districts.

In Governance sector: Training on decentralization, women's leadership and good governance for 36 persons and 2 conferences debates (for 108 persons including 62 women) on assessment of the needs and preparatory activities for GBV were organized and carried.

With the private sector: Handcraft industry secretariat has been established in MINICOM to support women entrepreneurship.

At the decentralized level, a gender auditing tool was elaborated in a view of reinforcing capacities in the implementation of the EDPRS in 5 pilot Districts (Bugesera, Nyarugenge, Musanze, Ngororero and Nyamagabe.

\subsection{REGARDING SOCIAL INCLUSION}

Solidarity camp for street children was carried out and many of them were enrolled in primary schools whilst some were retained in their families. Regular monitoring of the implementation of the convention related to child rights is being conducted.

Currently ECD services are provided by many members of the private and voluntary sector partner with the Government. However, these partnerships are mainly informal in nature, and few partnerships have established formal agreements. Standards, guidelines and regulations for ECD services are generally lacking.

In Rwanda, latest figures indicate that only $13.3 \%$ of pre-primary school-age children are attending pre-primary school. In this context, the Government of Rwanda under MINEDUC developed the ECD Policy and a 5 year Strategic plan (2010-2015) in a vision of contributing to the implementation of ECD policy, improving, expanding, strengthening and promoting integrated services for full potential development of Rwandan children, enhancing the well-being of their family, to contribute in the reduction of poverty in the community and country through coordination, Monitoring and evaluation of all intervention from stakeholders(vertical and horizontal.

The national vision for the integrated development of infants and young children covers the period from preconception and antenatal education and care to 6 years of age.

The living conditions in TIG work camps (Ingando) are as good as those in prisons. All convicts are subject to the same conditions and treatment. However some positive exceptions are observed for specific categories like disabled, 
elderly, weak people, etc for whom the coordination team allocates the daily tasks according to their strength and abilities to work.

Transport sub-sector contributes to social benefits such as the creating access to transportation infrastructure for the general population, and the creation of access routes for the development of commerce and trade. The transport subsector also continues to create new job opportunities to the population in rural area with the construction, rehabilitation and maintenance of feeder roads using the HIMO as a direct approach to poverty reduction.

The agriculture sector initiated a project which will guarantee "One Cup of Milk per Child" in schools. This will not only instill a culture of milk drinking where this is not already present spurring on the development of a milk value chain, but will also improve nutritional levels, so that the MDGs can be achieved and young people may have the best possible start in life.

Social protection sector also considers inclusion of 6 categories of people in its planning process (Elderly, vulnerable children, ex-combatants, genocide survivals, refugees, disable people) : Over 41,000 genocide survivors received support for secondary school, 4,883 for tertiary education and nearly 200,000 with 'mutuelle de sante'. 1,946 disabled ex-combatants received a monthly allowance. 6,795 vulnerable children received support through MIGEPROFE and the global fund. 12,710 refugees were assisted in voluntary repatriation and 54,000 refugees receive humanitarian assistance. 434 households from Gishwati high risk zone received support to resettle. Reporting is improving but improvements are still needed to accurately capture delivery across the sector and to evaluate impact.

\subsection{IN RELATION TO HIV/AIDS}

HIV is addressed not only as a health issue but as a cross cutting issue, requiring all EDPRS sectors to include it deliberately and actively into their strategic planning.

CNLS has developed a new national strategic plan to fight HIV and AIDS aligned to the EDPRS, which sets out the overarching goals for the response to HIV and AIDS as well as reaffirming Rwanda's commitment to a multi-sector response. In this perspective, CNLS has built and strengthened the capacity of officials from 7 sectors (Education, Youth, private sector, agriculture, transport, justice and social protection) and other stakeholders (Umbrella of NGO, un Agencies and other partners) in developing HIV Plan in their respective plans using Results based management approach.

MIFOTRA, Districts and Public Umbrella in fighting HIV and AIDS organized awareness training in HIV and AIDS and VCT (Volunteer, Cancelling and Testing) in 13 Districts and 90 Staffs of IRST. MIFOTRA appointed in each Ministry and Public Institutions, 32 Focal Points in HIV and AIDS and started the elaboration of the Strategic plan 2010-2012 for HIV/AIDS in the Public sector.

At the decentralized level, all the 30 districts have been supported to incorporate HIV/AIDS as appropriate into the district integrated planning tools such as Medium Term Expenditure Frameworks (MTEF) and Annual Work Plans (AWP). HIV/AIDS voluntary test and counselling in schools were also conducted.

Isange One Stop Center in the National Police was established and is responsible for fighting and sensitizing community members against sexual and gender violence. Counselling and treatment of victims of sexual/GBV and prevention of HIV/AIDS are its most important activities.

\subsection{REGARDING ENVIRONMENT AND CLIMATE CHANGE}

Important common tools have been applied such as the EIA (environment impact assessment) in order to mitigate impact of different interventions on environment. The use of Environment impact assessments as tools to assess the environmental impact of projects was institutionalized by publishing EIA sectoral guidelines for fuel stations, slaughter-houses and tanneries, and more than 100 projects received certificates by Rwanda Environment Management Authority. 
For the first time, after the launching of PRSP/EDPRS the Environment Public expenditure review was conducted as a baseline review that seeks to support the implementation of Environment and Natural Resources (ENR) Sector Strategic Plan and Joint Sector Reviews.

The overall purpose was:

- Raising the profile of environment in sustainable development agenda,

- Improving equity, efficiency, effectiveness of public spending for pro-poor growth,

- Demonstrate the contribution of environment to national growth

- Drawing lessons-good and not good alike- to improve sectoral planning and resource use.

Among findings, there is a link between the Macro-economic performances: GDP and environment ENR-based GDP was $35 \%$, coinciding with subsidized fertilizers, water harvesting, terracing, extension, etc. This contribution to GDP is still the highest and Rwanda has stretched its capacity to generate revenue from new sources, and can hopes to do so from the real GDP growth that will increase disposable income. However, investment to reduce climate change impacts by adaptation and mitigation are limited.

All sector engagements involving review of strategic plans and policies are aimed at integrating environment as another Cross cutting issue. Under the supervision of REMA preliminary steps in this direction were taken by MININFRA, MINALOC, MINAGRI, MINICOM, MINECOFIN MINELA and MINIFOM during the development of EIA, EFR and PER documents and training manuals, all of which helps to guide integration of environmental as a cross cutting issue. Extensive trainings have been provided to institutions, cooperatives (particularly those working with and exploitation for agricultural purposes) and the private sector.

3 projects pertaining to climate change mitigation within the carbon market framework were promoted. The national report on the Green House Gases was completed and a study on "Economics of Climate Change in Rwanda" has been undertaken.

\section{With Energy sector:}

Efforts have been increased in

- $\quad$ Reducing biomass consumption and increasing efficiency

- Increasing share of renewable energy, diversification of sources

- Increasing energy efficiency through grid audit, devices such as CFLs, Solar Water Heaters

- Mandatory management prescriptions for safe and sustainable methane gas extraction from Lake Kivu

- Accessing to Carbon financing.

Emphasis has also been put on alternative energy sources with solar energy and micro hydro centers particularly being set up as off-grid solutions for communities and administrative and health centers in rural areas.

Prisons have also initiated biogas to avoid deforestation, and environmental degradation in general. Prisoners also participate in tree planting and terracing activities.

Industry: Comprehensive cost based surveys for all commercial structures in Gikondo - Nyabugogo wetland system to guide expropriation of Gikondo industrial park and surrounding areas are also being conducted to avoid environmental degradation. Nyandungu free trade zone that will combine Kigali industrial park and free economic 
zone to relocate Gikondo Industrial park is being organized with infrastructures. The sites for 4 provincial industrial parks to relocate industries actually located in wetlands have been identified and EIA conducted.

\section{With regard to Water and sanitation:}

The overall access to safe water $75.7 \%$ from $74 \%$ in 2009 . There is still a high production cost resulting from destruction of water sources due to erosion, landslides causing siltation, floods and pollution. A dispersed habitat causing a delay in accessing water supply systems by rural households is an additional challenge.

The technology used in most sanitation projects is based on ECOSAN which is a good methodology that closes the loop on nutrients cycle, and does not pollute fresh, surface and ground water. It reduces waste materials to near zero and promotes the idea of a clean and safe environment for every one. A current report indicates that, 9175 ECOSAN latrines were constructed in schools and 9043 constructed in public places. 160 committees and Guidelines to operationalize HAMS10 and PHAST11 were available. The overall access to sanitation for Households is $56.3 \%$ from $45 \%$ last year.

With Education sector: Training of teachers in southern and Northern provinces on the environmental protection, implementation of projects designed by environmental clubs created in 17 schools in 3 districts (Nyabihu,Rubavu and Rutsiro) and a needs assessments for mainstreaming environment into the national curricula was carried out in primary, secondary and tertiary education institutions.

30 Environmental clubs in secondary schools have been visited to monitor environmental practices put in place and awards (promotional items of awareness material) have been given after inter school competition.

Agriculture: Areas of marshland developed for agricultural use (ha) with EIA have been completed for 650 ha among 2000 ha planned.

MINAGRI intervenes actively in environmental protection, particularly in the following areas:

- Erosion control - in the last few years, through the efforts of MINAGRI and districts, the area of land sustainably managed against erosion has increased from just $40 \%$ in 2006 to $80.9 \%$ in June 2010, thus largely addressing one of the most pressing issues in the sector.

- Agro-forestry - MINAGRI has encouraged the planting of trees for erosion control reasons and has ensured the maintenance of a large area of forests, such as those surrounding tea plantations.

- All major projects in the sector have to carry out an Environmental Impact Assessment prior to being funded by MINAGRI and its partners.

With Governance sector: The monthly community work (Umuganda) done by every citizen country wide promotes environmental protection where terracing is done on mountaining slopes to protect the soils from soil erosion, tree planting program also promotes environmental friendly programs.

Projects on Early Warning Systems in Nyabihu and other selected districts that are in the high risk zone launched. These are Africa Adaptation Program (AAP) aimed at building a comprehensive National Approach on early warning system.). Least Developed Countries Fund (LDCF), aimed at establishing early warning and disaster preparedness system and support for integrated water shed management in flood prone areas. Poverty Environment Initiative Project in its phase 2, to mainstream environment into National Planning and Budgeting as a key priority for sustainable development.

\footnotetext{
${ }^{10}$ Hygiène et Assainissement en milieu Scolaire

${ }^{11}$ Participatory Hyigiene And Sanitation Transformation
} 


\subsection{REGARDING YOUTH ISSUES}

- With Agriculture sector: Due to Rwanda's demographic trajectory, the agricultural sector is driven by young people and its future depends on their ability to become productive and market-oriented farmers. Thus MINAGRI makes every possible effort to ensure that young people and their needs are mainstreamed in the sector, by including them in all aspects of our work, but particularly in extension activities. MINAGRI is trailing new technologies to spread information to young people, including through the new AMIS website (www.amis.minagri.gov.rw) as well as the e-soko project which makes market data available through the internet and mobile phone technology.

- In infrastructures sector: a systematic survey on women and youth employment (Statistics on jobs created) within roads projects has been undertaken and is ongoing. Similarly, surveys and report will be conducted on HIV/AIDS and other social issues encountered during the road projects implementation.

- With Environmrnt sector: 12 Offices of District national Youth Council (DNYC) are equipped with Computers and accessories;

- 2380 youths have been sensitized and mobilized on the sustainable environment management (especially in the respect of the Environment organic law regarding protection of rivers) and cooperative principles;

- Creation of employment for youth to empower them. These 2380 youth have been employed to protect Nyabarongo and tributaries river banks on $519 \mathrm{~km}$ long by planting reeds.

- With the financial sector: Promotion of Youth cooperatives members of COJAD in 12 Districts: the 2380 Youths have opened their accounts in various Financial Institutions; the saving culture for youth in rural areas has been promoted. The savings made will in future serve as a collateral when accessing development loans from RDB (case in Ruhango District); 


\section{SUMMARY OF EMERGING ISSUES}

- In overall, a total of $\mathbf{1 2 3}$ policy actions were planned for 2009/10 . Out of these, a total of $\mathbf{8 7}$ policy actions (71\%) were completed (G), 27 policy actions $(\mathbf{2 2 \%})$ were partially achieved $(\mathbf{Y})$ and 9 policy actions (7\%) were lagging significantly behind (R). Corresponding targets were also implemented as follows: Out of 73 targets planned, 56 were fully achieved (77\%), 5 targets were partially achieved (7\%), 2 targets were not achieved (3\%) and $10(15 \%)$ targets were not assessed due to ongoing surveys that will provide the required data.

- It becomes clear that the Government of Rwanda has shown its commitment in implementing the set goals in the Economic Development and Poverty Reduction Strategy (EDPRS) 20082012. It is therefore striving to achieve higher program performance, and consequently higher social and economic development.

- In most areas, it was observed that some of the targets have been exceeded. In these areas the projections for the future need to be revised upwards in order to match with higher performances of clusters and their corresponding sector.

- On the whole, the concept of Imigiho as a development strategy has led to promising results by promoting a competitive spirit and creating focused and enthusiastic effort which are essential components to the long awaited development. In addition, the strategy has promoted an effective mechanism of monitoring and evaluation of development initiatives, which is essential to promote focused development.

- The theory of change is needed to review the outcomes \& indicators of the EDPRS and setting up a task force for each of the 3 strategic results may be necessary to ensure their implementation at sector level,

- There is need to address the ambiguity that is apparent in the EDPRS Results and Policy Matrix/CPAF (in the view of the theory of change). Most of the statements indicated as outcomes/ outcome indicators are actually outputs. The layout of the EDPRS Matrix should be redesigned to clearly show outcomes and their indicators. Some targets are unrealistic and others expressed in measures that are not appropriate. The sectors will have to redesign some targets, add the missing targets and baselines.

- Finalization of studies on assessment of legal, policy and institutions framework and Investment opportunities in EAC need to be speed up.

- Due to the remarkable increase in the agriculture production, a strong focus should be put on the improvement of postharvest and strategic storage in order to minimize losses and to continue to tackle malnutrition (MDG). USAID and WFP have offered to train on warehouse management and post-harvest management. Therefore, it is recommended that MINAGRI undertake analysis of potential consequences of Strategic Grain Reserve (e.g. different management approaches, fiscal implications, etc) as part of its design; 
- The productions of coffee and tea have recorded low increases towards achieving EDPRS targets. Thus, it is recommended that MINAGRI conduct a mid-term evaluation of key EDPRS targets as well as a review of the targets for which performance has already been exceeded in preparation for the next forward looking JSR in which targets and actions can be revised,

- Lack of staff capacity to implement programmes and projects: this is a big challenge that affects the entire road transport network and subsequently the two CPAF indicators without forgetting that this sub-programme covers the big share of the budget in Transport sub sector. Therefore the development of classified road network Infrastructure to meet good conditions requires well-trained and capable staff to do it.

- Closer follow up of tree plantation exercise is required to assess why in some areas there is high percentage loss of trees planted. Overall losses amounted to close to $30 \%$ of the trees planted in 2008

- Many health facilities managed by churches do not deliver modern contraceptive methods. This requires the establishment of a secondary health post in the vicinity of faith based Health Facilities hence more additional resources/budget required.

- Though the Ministry of Education is one of the Ministries to get an important portion from the total budget of the country, the uniqueness and importance of activities that were planned for at national level has made it impossible to operate within the allocated budget. Therefore, most institutions under the Ministry were given a small portion of their required budget and were requested to try to cope with or where applicable encouraged to generate income to top up this budget.

- On social protection, the finalization and approval of the social protection strategy is critical to making significant progress in the sector in terms of reaching the right people and impacting on poverty reduction as well as enhancing better budgeting, planning and reporting. Importantly, the strategy will be critical to the coordination of social protection interventions from different institutions.

- A decision to channel government support through a youth window that has to be established under Umurenge Sacco was reached and that COOJAD would be phased out. This requires a close follow up and inform all stakeholders.

- Interventions by different stakeholders in the Decentralization, Citizen Participation, Empowerment, Transparency and Accountability (DCPETA) Sector need a proper coordination and communication system to avoid duplication of efforts. Hence a need for harmonization of donor intervention

- The established Task Force focusing on the treatment of minors in conflict with the law will establish a first baseline concerning the quantity of juveniles in detention, their treatment, and the time spent in detention. This task force will come up with proposals to improve the 
treatment of minors. Furthermore the legal aid week will again focus on the assistance to minors. All these need a close follow-up.

- Low levels of PFM capacity at Central Government, Districts, Provinces and facilities such as hospitals, schools and prisons- This challenge is being addressed by ensuring that adequate human resources are availed to all Government entities, undertaking institutional restructuring and by carrying out continuous capacity building programs.

- Increasing investment in key sectors: the current situation shows that mortgage and real estate as well as agri-business are the least well financed through bank loans, despite their importance to our economic development. For example demographic and urbanization projections show that there is a need for 25,000 new houses every year, at an average cost of Rwf 500 billion, when in 2009 only Rwf 53.3 billion was granted for this purpose. The total amount of loans distributed in the agri-business represented just $1 \%$ of all loans granted by banks, even though the agriculture sector represents around 33\% of the GDP.

- There is a need to continue to improve Cross Cutting Issues coverage in the EDPRS monitoring and Evaluation by reaffirming its importance for the implementation process. 
ANNeX: Detailed EDPRS Result AND Policy Matrix (RPM) July 2009-June 10

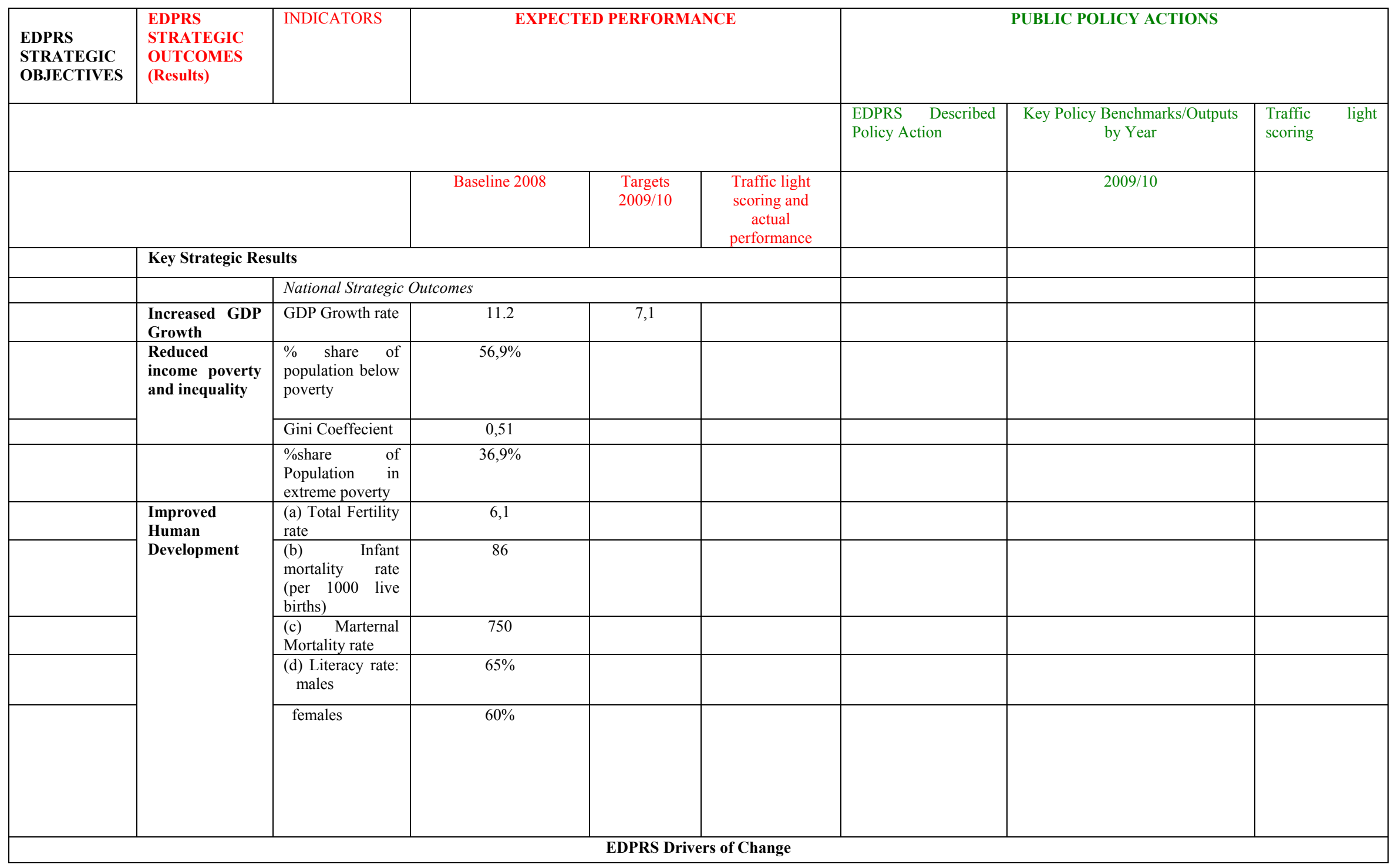

CInternational Monetary Fund. Not for Redistribution 


\begin{tabular}{|c|c|c|c|c|c|c|c|c|}
\hline \multirow[t]{2}{*}{$\begin{array}{l}\text { EDPRS } \\
\text { STRATEGIC } \\
\text { OBJECTIVES }\end{array}$} & $\begin{array}{l}\text { EDPRS } \\
\text { STRATEGIC } \\
\text { OUTCOMES } \\
\text { (Results) }\end{array}$ & INDICATORS & \multicolumn{3}{|c|}{ EXPECTED PERFORMANCE } & \multicolumn{3}{|c|}{ PUBLIC POLICY ACTIONS } \\
\hline & & & & & & $\begin{array}{l}\text { EDPRS Described } \\
\text { Policy Action }\end{array}$ & $\begin{array}{l}\text { Key Policy Benchmarks/Outputs } \\
\text { by Year }\end{array}$ & $\begin{array}{ll}\text { Traffic } & \text { light } \\
\text { scoring } & \end{array}$ \\
\hline & & & Baseline 2008 & $\begin{array}{c}\text { Targets } \\
2009 / 10\end{array}$ & $\begin{array}{l}\text { Traffic light } \\
\text { scoring and } \\
\text { actual } \\
\text { performance } \\
\end{array}$ & & $2009 / 10$ & \\
\hline \multirow{4}{*}{$\begin{array}{l}\text { 1. Increased } \\
\text { Economic } \\
\text { Growth }\end{array}$} & \multicolumn{8}{|c|}{ Macroeconomic stability consistent with private sector led growth } \\
\hline & \multirow[t]{3}{*}{$\begin{array}{l}1.1 \quad \text { Prudent } \\
\text { macro economic } \\
\text { management } \\
\text { ensured }\end{array}$} & $\begin{array}{l}1.1 .1 \quad \text { Net } \\
\text { domestic } \\
\text { financing (as } \% \\
\text { of GDP) }\end{array}$ & $(-) 3.3 \%$ & $<0.5$ & $0.36 \%$ & $\begin{array}{l}\text { Expenditures } \\
\text { Align Ministry } \\
\text { spending with the } \\
\text { MTEF and Strategic } \\
\text { plan }\end{array}$ & $\begin{array}{l}\text { Prepare and implement } 2010 \\
\text { budget in line with the EDPRS } \\
\text { priorities and the medium term } \\
\text { macro framework }\end{array}$ & $\begin{array}{l}2010 / 11 \text { Budget } \\
\text { projections were } \\
\text { prepared and } \\
\text { used in } 20 / 11 \\
\text { budget and are } \\
\text { in line with the } \\
\text { EDPRS } \\
\text { priorities and the } \\
\text { medium term } \\
\text { macro } \\
\text { framework }\end{array}$ \\
\hline & & $\begin{array}{l}\text { 1.1.2 Increase of } \\
\text { tax revenue to } \\
\text { GDP ratio } \\
\text { (indicative) }\end{array}$ & 0.4 & 0.2 & $0.3 \%$ & $\begin{array}{l}\text { Revenues: Implement } \\
\text { new tax policy } \\
\text { measures as per } 2007 \\
\text { tax policy and } \\
\text { strategy }\end{array}$ & $\begin{array}{l}\text { Implement tax policy measures } \\
\text { (i.e. agree on double taxation and } \\
\text { prevention of tax erosion, } \\
\text { harmonise excise tax structures, } \\
\text { internalise CU protocol and adopt } \\
\text { custom management act) to } \\
\text { comply with EAC customs union }\end{array}$ & $\begin{array}{lr}\text { Different tax } \\
\text { working groups } \\
\text { from } \\
\text { member } \\
\text { countries were } \\
\text { formed to } \\
\text { analyse the } \\
\text { impact of tax } \\
\text { harmonization. } \\
\text { Customs } \\
\text { management act } \\
\text { is under } \\
\text { implementation } \\
\text { as required. }\end{array}$ \\
\hline & & $\begin{array}{l}1.1 .3 \quad \text { Inflation } \\
\text { rate } \quad \text { (core } \\
\text { inflation annual } \\
\% \text { change, end } \\
\text { period basis) }\end{array}$ & $15.4 \%$ & Single digit & $4.7 \%$ & $\begin{array}{l}\text { Set monetary policy } \\
\text { to retain single digit } \\
\text { inflation. Use reserve } \\
\text { money growth as } \\
\text { policy instrument }\end{array}$ & $\begin{array}{l}\text { BNR to use policy instruments: } \\
\text { Reserve requirement; Foreign } \\
\text { exchange sales; and Treasury bill } \\
\text { sales to mop up excess liquidity } \\
\text { such that monetary policy targets } \\
\text { are achieved. }\end{array}$ & $\begin{array}{l}\text { Banks benefited } \\
\text { from important } \\
\text { liquidity } \\
\text { injection } \\
\text { through the } \\
\text { reduction of the } \\
\text { Reserve } \\
\text { Requirement } \\
\text { Ratio from } 8 \%\end{array}$ \\
\hline
\end{tabular}

CInternational Monetary Fund. Not for Redistribution 


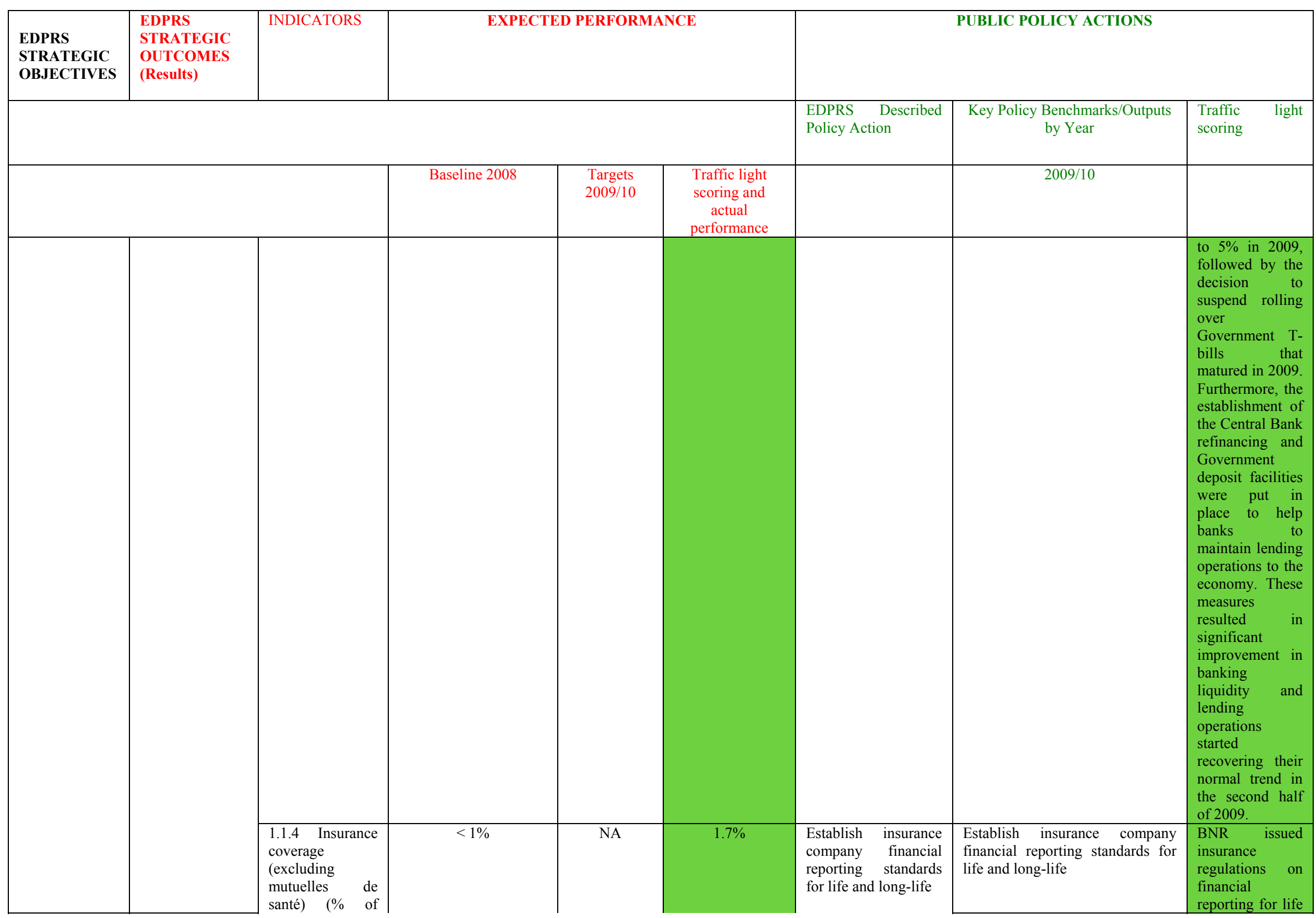




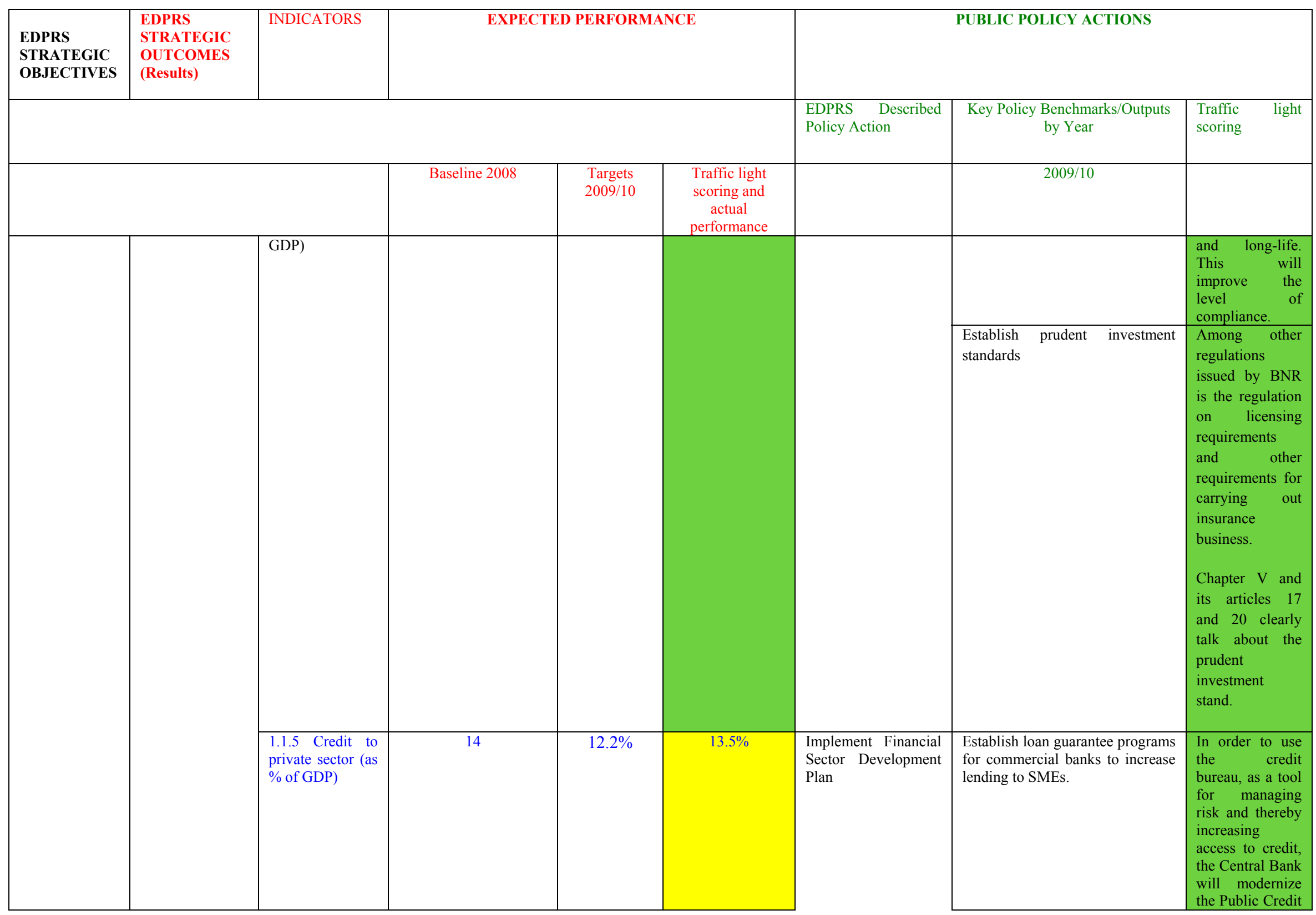

CInternational Monetary Fund. Not for Redistribution 


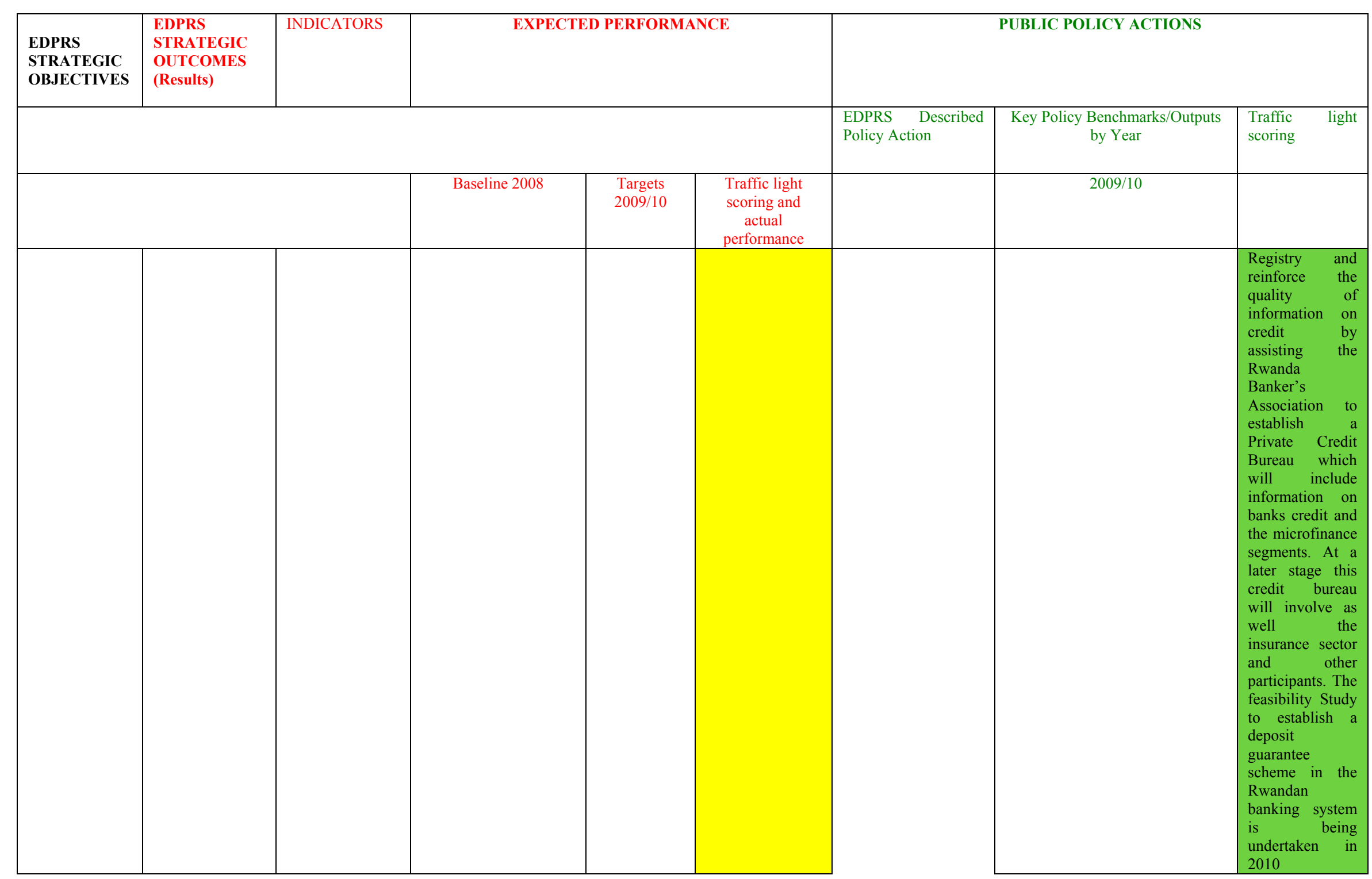

CInternational Monetary Fund. Not for Redistribution 


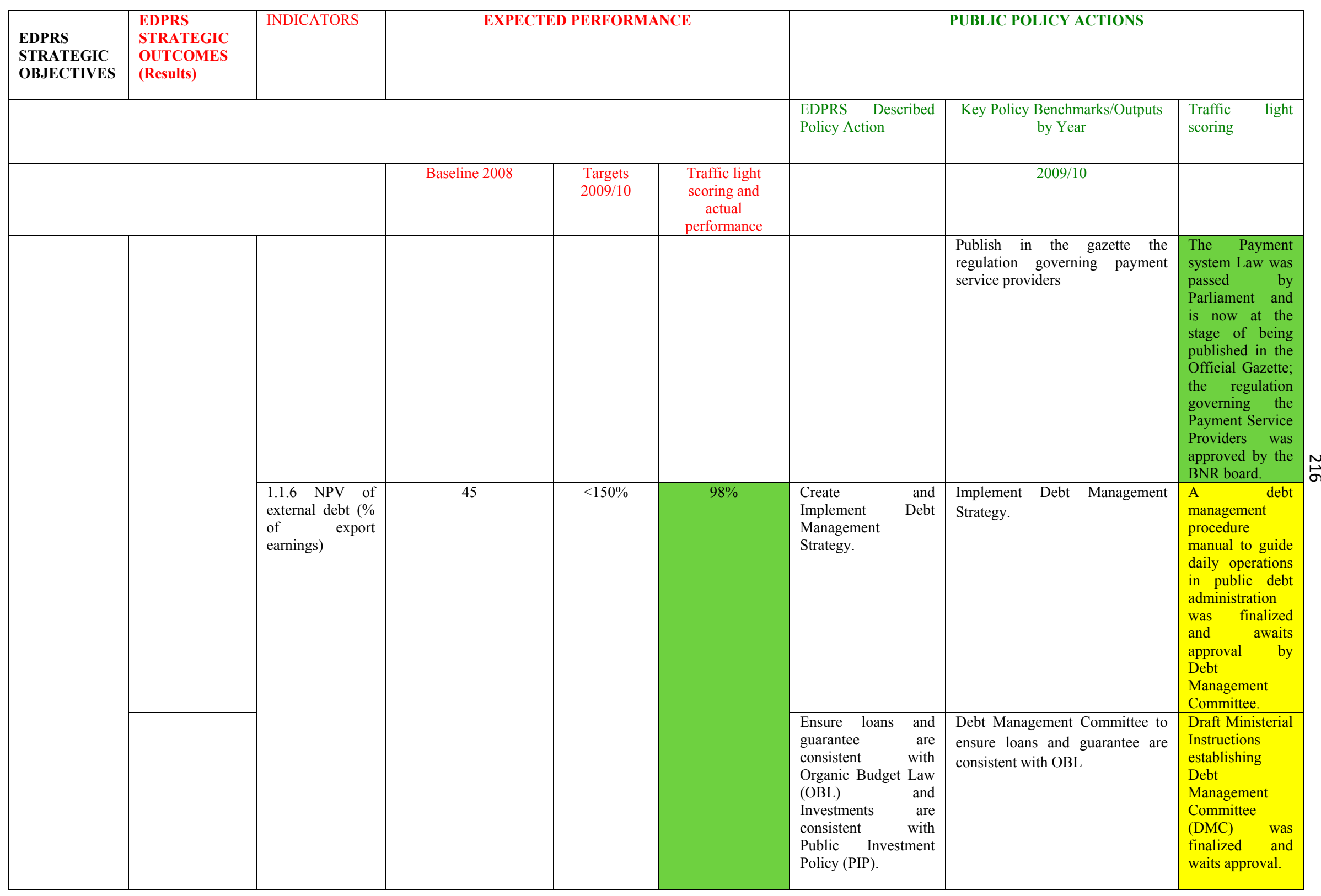




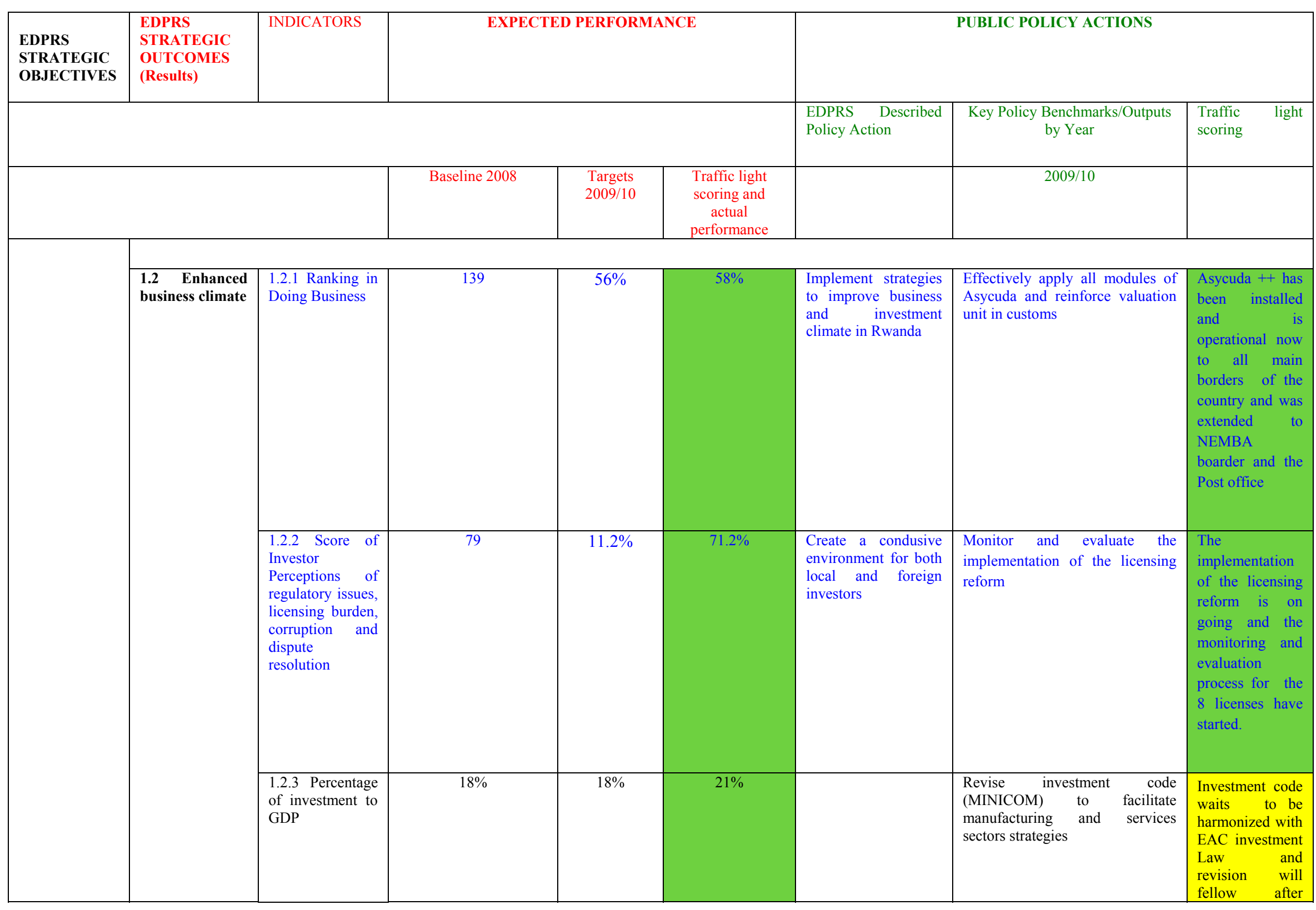




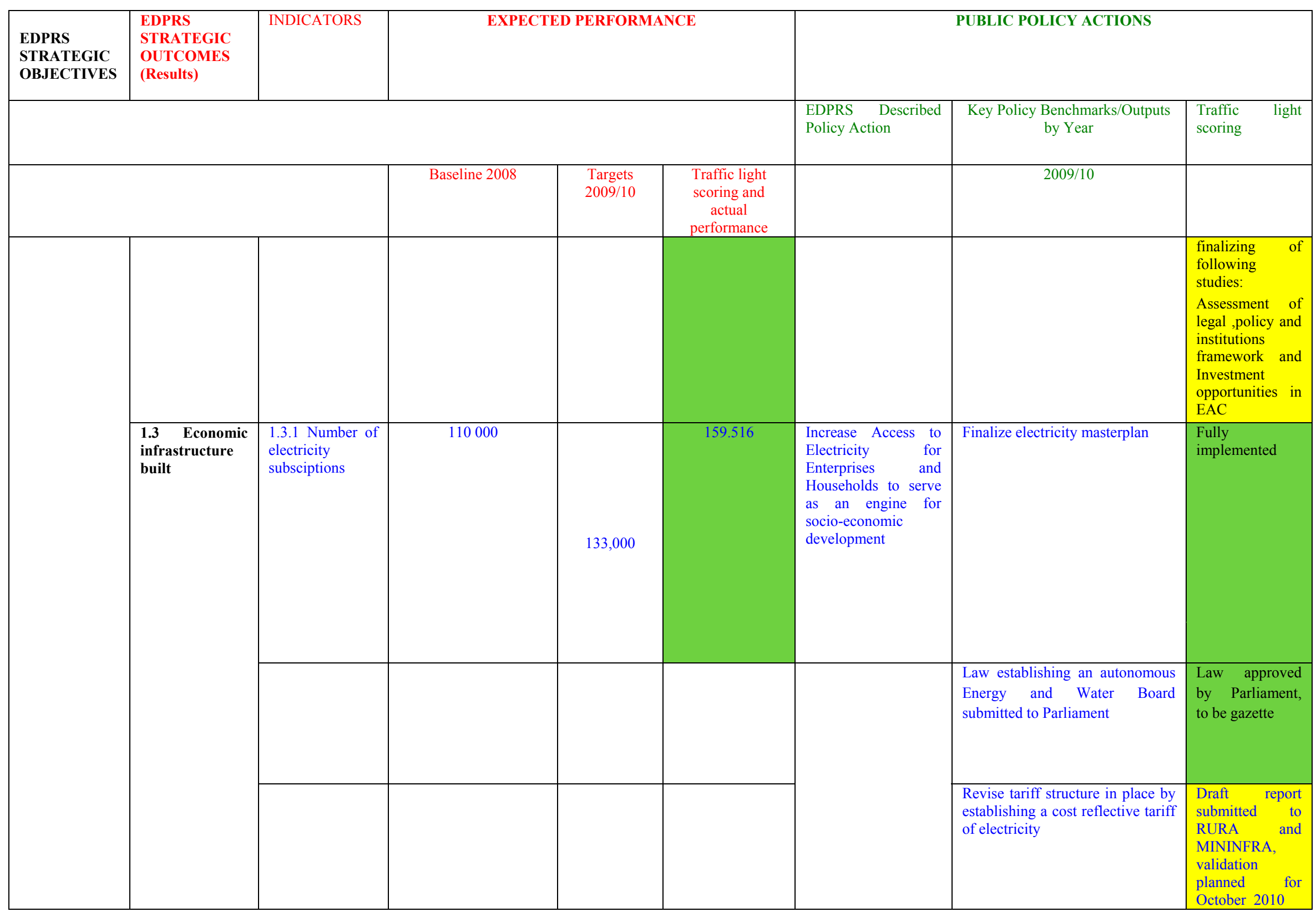




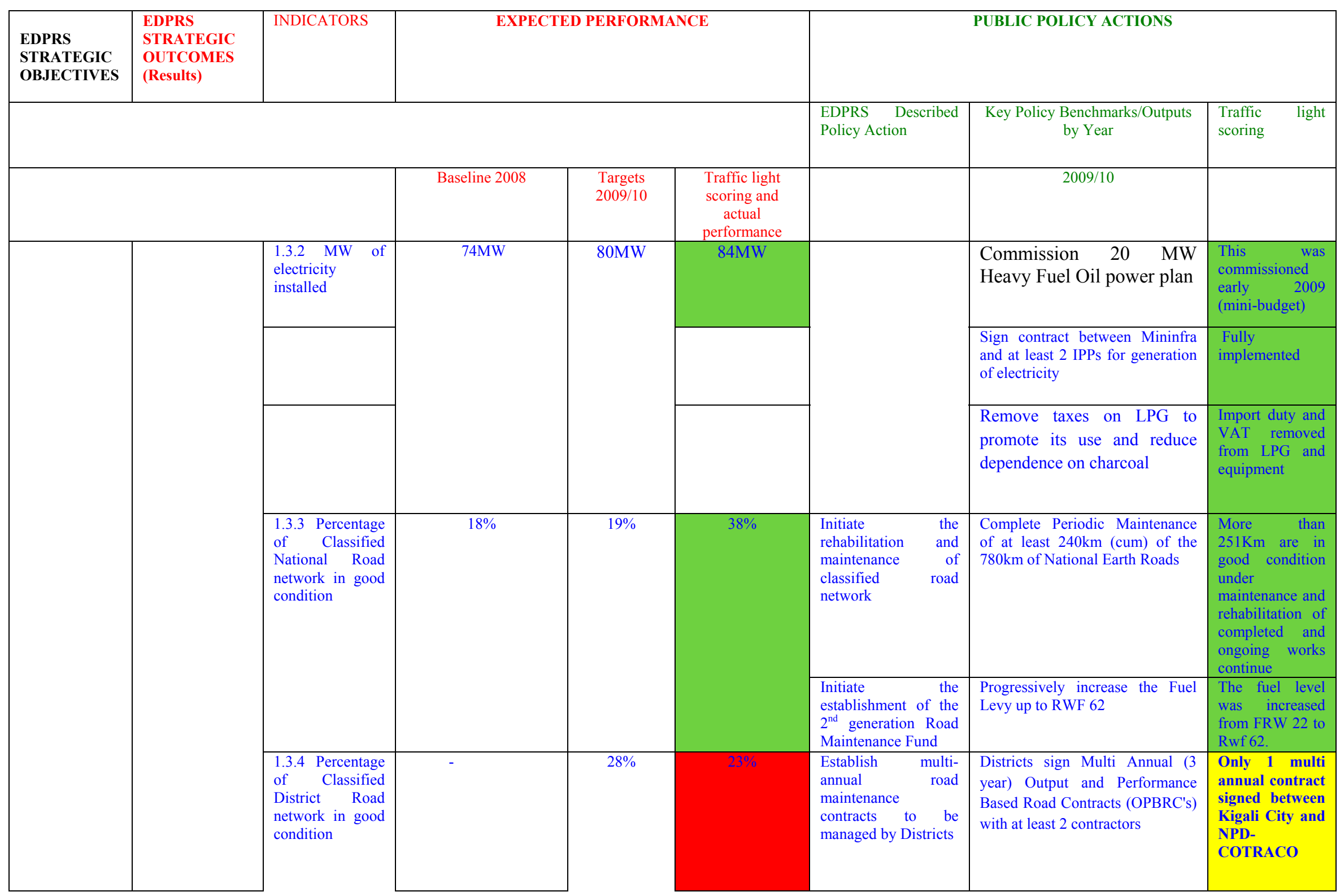

(CInternational Monetary Fund. Not for Redistribution 


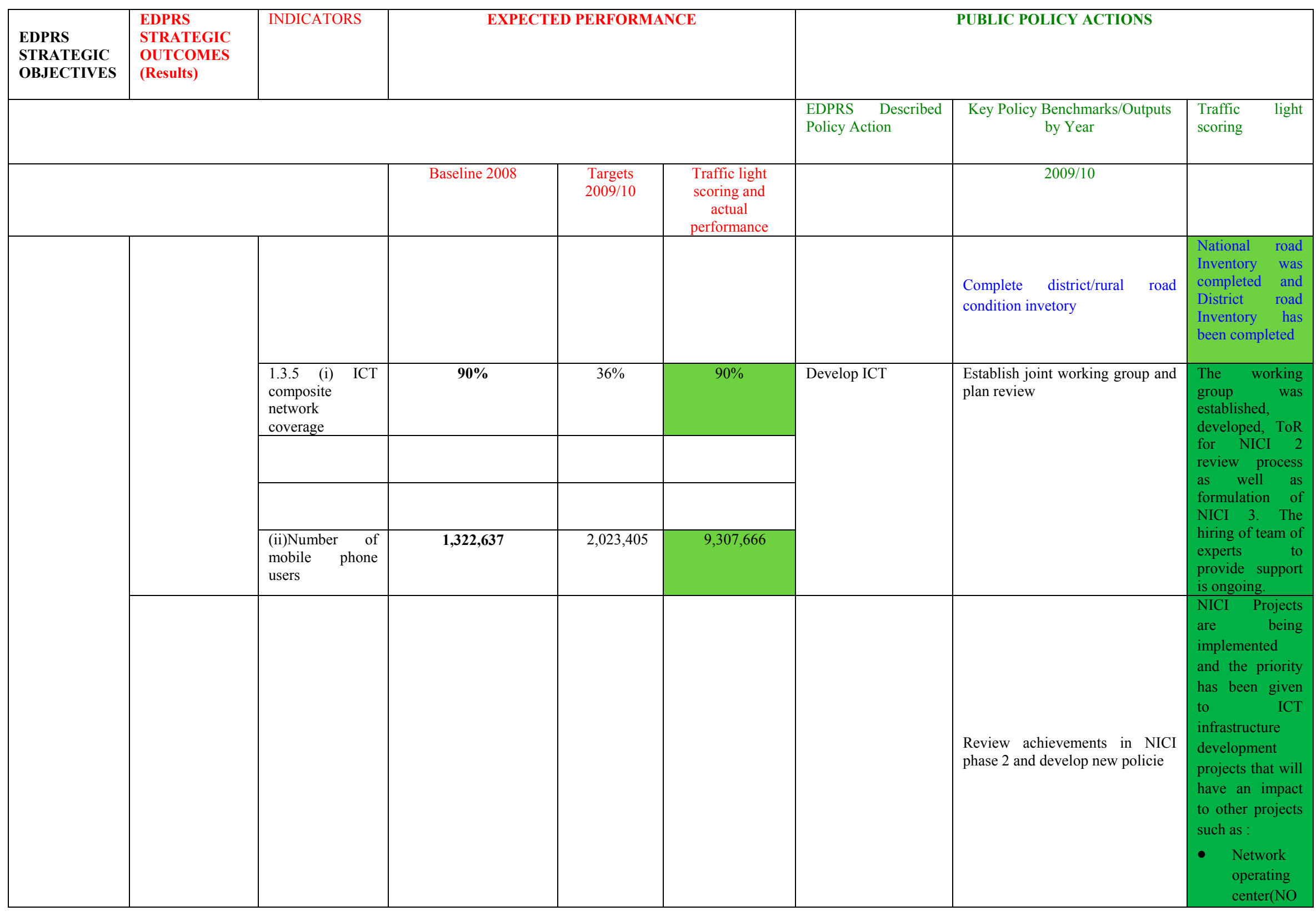

CInternational Monetary Fund. Not for Redistribution 


\begin{tabular}{|c|c|c|c|c|c|c|c|c|}
\hline $\begin{array}{l}\text { EDPRS } \\
\text { STRATEGIC } \\
\text { OBJECTIVES }\end{array}$ & EDPRS & INDICATORS & \multicolumn{3}{|c|}{ EXPECTED PERFORMANCE } & \multicolumn{3}{|c|}{$\begin{array}{l}\text { PUBLIC POLICY ACTIONS } \\
\end{array}$} \\
\hline & & & & & & $\begin{array}{l}\text { EDPRS Described } \\
\text { Policy Action }\end{array}$ & $\begin{array}{l}\text { Key Policy Benchmarks/Outputs } \\
\text { by Year }\end{array}$ & $\begin{array}{ll}\text { Traffic } & \text { light } \\
\text { scoring } & \end{array}$ \\
\hline & & & Baseline 2008 & $\begin{array}{l}\text { Targets } \\
2009 / 10\end{array}$ & $\begin{array}{l}\text { Traffic light } \\
\text { scoring and } \\
\text { actual } \\
\text { performance }\end{array}$ & & $2009 / 10$ & 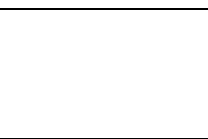 \\
\hline & & & & & & & & $\begin{array}{l}\text { C) has } \\
\text { been built } \\
\text { in telecom } \\
\text { house } \\
\text {,Wibro and } \\
\text { KMN has } \\
\text { been } \\
\text { launched, } \\
\text { its services } \\
\text { are under } \\
\text { testing } \\
\text { while } \\
\text { working on } \\
\text { its } \\
\text { manageme } \\
\text { nt and } \\
\text { commercia } \\
\text { lization } \\
\text { National } \\
\text { Backbone } \\
\text { redesign } \\
\text { and } \\
\text { contract } \\
\text { reviewed } \\
\text { with KT } \\
\text { on building } \\
\text { backbone } \\
\text { to include } \\
\text { provisions } \\
\text { of further } \\
\text { fiber } \\
\text { laying and } \\
\text { Gatuna to }\end{array}$ \\
\hline
\end{tabular}

CInternational Monetary Fund. Not for Redistribution 


\begin{tabular}{|c|c|c|c|c|c|c|c|c|}
\hline $\begin{array}{l}\text { EDPRS } \\
\text { STRATEGIC } \\
\text { OBJECTIVES }\end{array}$ & $\begin{array}{l}\text { EDPRS } \\
\text { STRATEGIC } \\
\text { OUTCOMES } \\
\text { (Results) }\end{array}$ & INDICATORS & \multicolumn{3}{|c|}{ EXPECTED PERFORMANCE } & \multicolumn{3}{|c|}{ PUBLIC POLICY ACTIONS } \\
\hline & & & & & & $\begin{array}{l}\text { EDPRS Described } \\
\text { Policy Action }\end{array}$ & $\begin{array}{l}\text { Key Policy Benchmarks/Outputs } \\
\text { by Year }\end{array}$ & $\begin{array}{ll}\text { Traffic } & \text { light } \\
\text { scoring } & \end{array}$ \\
\hline & & & Baseline 2008 & $\begin{array}{l}\text { Targets } \\
2009 / 10\end{array}$ & $\begin{array}{l}\text { Traffic light } \\
\text { scoring and } \\
\text { actual } \\
\text { performance } \\
\end{array}$ & & $2009 / 10$ & . \\
\hline & & & & & & & & $\begin{array}{l}\text { Kigali } \\
\text { route has } \\
\text { been } \\
\text { finalized, } \\
\text { National } \\
\text { datacenter } \\
\text { project physical } \\
\text { construction is } \\
\text { in finalized } \\
\text { preparations of } \\
\text { phase } 2 \text { have } \\
\text { started }\end{array}$ \\
\hline & $\begin{array}{l}\text { 1.4 Increased } \\
\text { contribution of } \\
\text { strategic } \\
\text { exports to GDP }\end{array}$ & $\begin{array}{l}1.4 .1 \quad \text { Revenue } \\
\text { from strategic } \\
\text { exports (tea, } \\
\text { coffee, } \\
\text { horticulture, } \\
\text { hides \& skins, } \\
\text { minerals), in US\$ } \\
\text { million }\end{array}$ & 185 & 198 & 164 & $\begin{array}{l}\text { Develop strategies to } \\
\text { increase production, } \\
\text { quality and } \\
\text { management of key } \\
\text { exports }\end{array}$ & $\begin{array}{l}\text { Establish Free trade zone in } \\
\text { Nyandugu }\end{array}$ & $\begin{array}{l}\text { Infrastructure } \\
\text { development } \\
\text { including roads } \\
\text { and electricity is } \\
\text { being done by } \\
\text { Horizon and } \\
\text { partners. Final } \\
\text { and detailed } \\
\text { architectural } \\
\text { designs and bills } \\
\text { of quantity } \\
\text { complete. }\end{array}$ \\
\hline & & $\begin{array}{l}1.4 .2 \text { Revenue } \\
\text { from tourism, in } \\
\text { US\$ million }\end{array}$ & 185 & 208 & 182 & Diversify tourism & $\begin{array}{l}\text { Diversify tourism products and } \\
\text { introduce } \\
\text { E-tourism }\end{array}$ & $\begin{array}{l}\text { Birding was } \\
\text { launched as a } \\
\text { new product } \\
\text { with } \\
\text { identification of } \\
\text { a bird tourism } \\
\text { circuit, including } \\
\text { the ongoing } \\
\text { construction of a }\end{array}$ \\
\hline
\end{tabular}




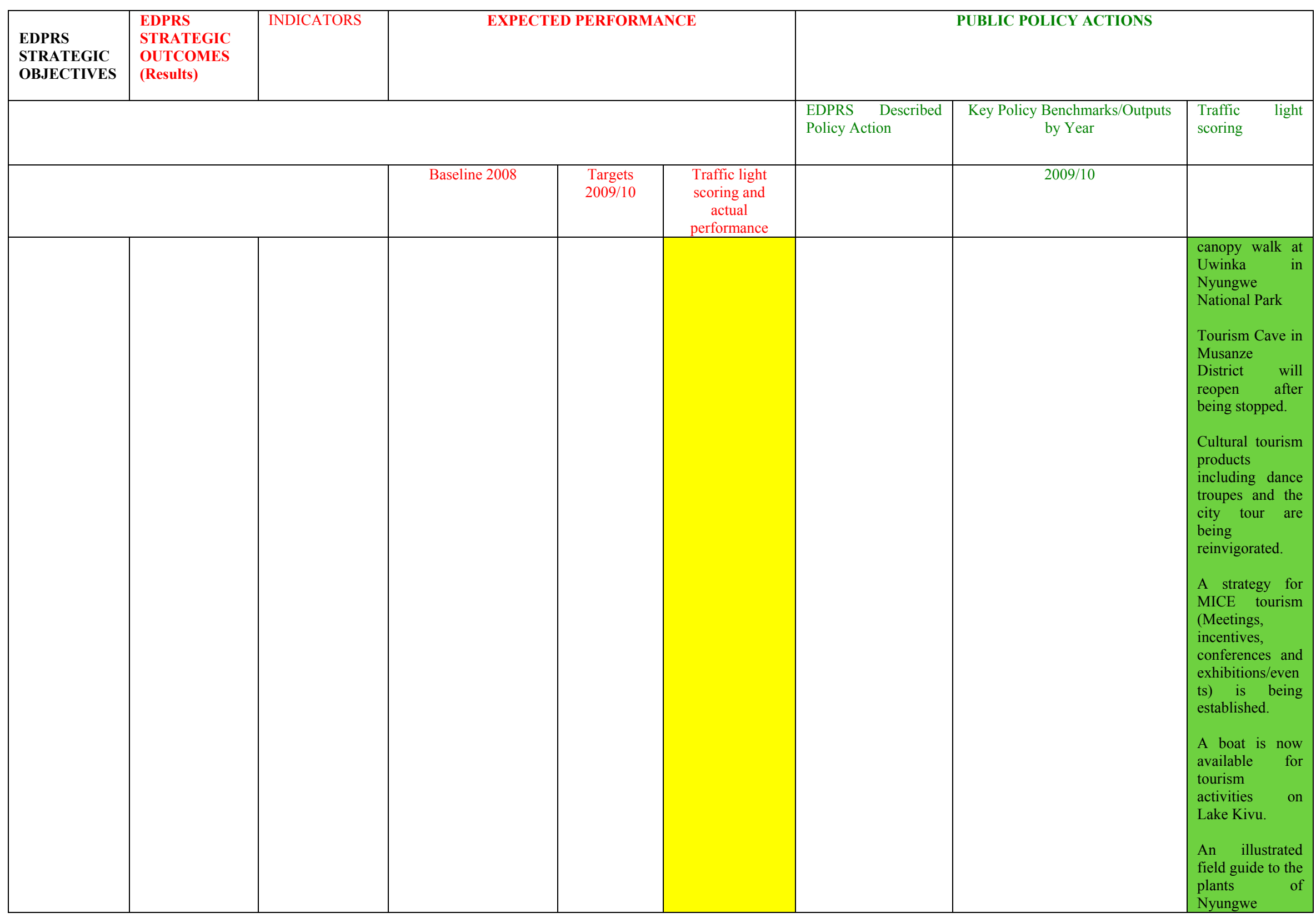

CInternational Monetary Fund. Not for Redistribution 


\begin{tabular}{|c|c|c|c|c|c|c|c|c|}
\hline \multirow{2}{*}{$\begin{array}{l}\text { EDPRS } \\
\text { STRATEGIC } \\
\text { OBJECTIVES }\end{array}$} & $\begin{array}{l}\text { EDPRS } \\
\text { STRATEGIC } \\
\text { OUTCOMES } \\
\text { (Results) }\end{array}$ & INDICATORS & \multicolumn{3}{|c|}{ EXPECTED PERFORMANCE } & \multicolumn{3}{|c|}{ PUBLIC POLICY ACTIONS } \\
\hline & & & & & & Policy Action & $\begin{array}{l}\text { Ney Yoricy Year } \\
\text { bys/Cupus }\end{array}$ & scoring \\
\hline & & & Baseline 2008 & $\begin{array}{c}\text { Targets } \\
2009 / 10\end{array}$ & $\begin{array}{l}\text { Traffic light } \\
\text { scoring and } \\
\text { actual } \\
\text { performance }\end{array}$ & & $2009 / 10$ & . \\
\hline & & & & & & & & $\begin{array}{ll}\text { National } & \text { Park } \\
\text { has } & \text { been } \\
\text { produced. } & \end{array}$ \\
\hline & & & & & & $\begin{array}{lr}\text { Construct } & \text { and/or } \\
\text { rehabilitate } & \text { regional } \\
\text { museums } & \end{array}$ & $\begin{array}{l}\text { Promote cultural exhibitions on } \\
\text { Karongi \& Kandt } \\
\text { (MIJESPSOC, Kigali city \& } \\
\text { Karongi district) }\end{array}$ & $\begin{array}{l}\text { Different } \\
\text { cultural } \\
\text { exhibitions were } \\
\text { done in different } \\
\text { museums in } \\
\text { order to promote } \\
\text { Rwanda's } \\
\text { culture. }\end{array}$ \\
\hline & & & & gricultur & uctivity and en & nmental management & & \\
\hline & $\begin{array}{l}1.5 \quad \text { Increased } \\
\text { agricultural } \\
\text { productivity }\end{array}$ & $\begin{array}{l}\text { 1.5.1 Percentage } \\
\text { of land area } \\
\text { protected against } \\
\text { soil erosion }\end{array}$ & $44.5 \%$ & $50 \%$ & $81 \%$ & $\begin{array}{lr}\text { Develop } & \text { and } \\
\text { implement } & \\
\text { programmes } & \text { for } \\
\text { construction } & \text { and } \\
\text { rehabilitation } & \text { of } \\
\text { (progressive } & \& \\
\text { radical) terraces } & \text { and } \\
\text { erosion control } & \end{array}$ & $\begin{array}{l}\text { Feasibility studies for the latter } 14 \\
\text { sites are completed and made } \\
\text { available by MINAGRI. }\end{array}$ & 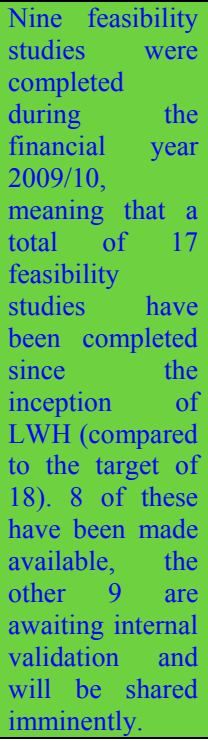 \\
\hline
\end{tabular}




\begin{tabular}{|c|c|c|c|c|c|c|c|c|}
\hline \multirow{2}{*}{$\begin{array}{l}\text { EDPRS } \\
\text { STRATEGIC } \\
\text { OBJECTIVES }\end{array}$} & $\begin{array}{l}\text { EDPRS } \\
\text { STRATEGIC } \\
\text { OUTCOMES } \\
\text { (Results) }\end{array}$ & INDICATORS & \multicolumn{3}{|c|}{ EXPECTED PERFORMANCE } & \multicolumn{3}{|c|}{ PUBLIC POLICY ACTIONS } \\
\hline & & & & & & $\begin{array}{l}\text { EDPRS Described } \\
\text { Policy Action }\end{array}$ & $\begin{array}{l}\text { Key Policy Benchmarks/Outputs } \\
\text { by Year }\end{array}$ & $\begin{array}{l}\text { Traffic light } \\
\text { scoring }\end{array}$ \\
\hline & & & Baseline 2008 & $\begin{array}{l}\text { Targets } \\
2009 / 10\end{array}$ & $\begin{array}{l}\text { Traffic light } \\
\text { scoring and } \\
\text { actual } \\
\text { performance } \\
\end{array}$ & & $2009 / 10$ & 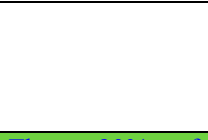 \\
\hline & & & & & & & . & $\begin{array}{l}\text { Thus, } 90 \% \text { of } \\
\text { this target has } \\
\text { been achieved. }\end{array}$ \\
\hline & & & & & & & $\begin{array}{l}\text { Strategy for mass sensitisation } \\
\text { on proposed land } \\
\text { consolidation developed and } \\
\text { endorsed by MINAGRI and } \\
\text { shared with the Rural Cluster }\end{array}$ & $\begin{array}{l}\text { The Strategy } \\
\text { was drafted, } \\
\text { shared with } \\
\text { the ASWG } \\
\text { and the Land } \\
\text { Use } \\
\text { Consolidation } \\
\text { Order was } \\
\text { adopted by the } \\
\text { Cabinet in } \\
\text { March } 2010 .\end{array}$ \\
\hline
\end{tabular}




\begin{tabular}{|c|c|c|c|c|c|c|c|c|}
\hline \multirow{3}{*}{$\begin{array}{l}\text { EDPRS } \\
\text { STRATEGIC } \\
\text { OBJECTIVES }\end{array}$} & \multirow{3}{*}{$\begin{array}{l}\text { EDPRS } \\
\text { STRATEGIC } \\
\text { OUTCOMES } \\
\text { (Results) }\end{array}$} & \multirow[t]{2}{*}{ INDICATORS } & \multirow{2}{*}{\multicolumn{3}{|c|}{ EXPECTED PERFORMANCE }} & \multicolumn{3}{|c|}{ PUBLIC POLICY ACTIONS } \\
\hline & & & & & & \\
\hline & & & & & & $\begin{array}{l}\text { EDPRS Described } \\
\text { Policy Action }\end{array}$ & $\begin{array}{l}\text { Key Policy Benchmarks/Outputs } \\
\text { by Year }\end{array}$ & $\begin{array}{ll}\text { Traffic } & \text { light } \\
\text { scoring } & \end{array}$ \\
\hline & & & Baseline 2008 & $\begin{array}{l}\text { Targets } \\
2009 / 10\end{array}$ & $\begin{array}{l}\text { Traffic light } \\
\text { scoring and } \\
\text { actual } \\
\text { performance }\end{array}$ & & $2009 / 10$ & \\
\hline & & $\begin{array}{l}1.5 .2 \text { Area of } \\
\text { marshland } \\
\text { developed for } \\
\text { agricultural use } \\
\text { (Has) }\end{array}$ & 12,092 & 14,000 & 13,354 & $\begin{array}{l}\text { Develop marshland } \\
\text { with pre-feasibility } \\
\text { studies and compliant } \\
\text { with environmental } \\
\text { guidelines }\end{array}$ & $\begin{array}{l}\text { Reclaim } 2000 \mathrm{Ha} \text { of Marshlands } \\
\text { and conduct feasibility studies for } \\
\text { 2000Ha of Marshlands }\end{array}$ & $\begin{array}{l}1,362 \text { ha of } \\
\text { marshland } \\
\text { rehabilitated by } \\
\text { end October } \\
2010 . \text { Feasibilitie } \\
\text { s for a further } \\
580 \text { ha are being } \\
\text { carried out. }\end{array}$ \\
\hline & & $\begin{array}{l}1.5 .3 \text { Proportion } \\
\text { of farming } \\
\text { households using } \\
\text { improved farm } \\
\text { methods }\end{array}$ & $\begin{array}{l}\text { NA (Unable to measure } \\
\text { the use of fertilizer at } \\
\text { the HH level annually) }\end{array}$ & 30,800 & $27,906.268$ & $\begin{array}{ll}\text { Operationalize } & \\
\text { National } & \text { Input } \\
\text { Strategy } & \end{array}$ & $\begin{array}{l}\text { Publish results and lessons } \\
\text { learned of an evaluation study of } \\
\text { the fertilizer }\end{array}$ & $\begin{array}{lr}\text { Study } & \text { was } \\
\text { conducted } & \text { and } \\
\text { published } & - \\
\text { shared } & \text { with } \\
\text { ASWG. } & \end{array}$ \\
\hline & & & & & & & $\begin{array}{l}\text { Develop, cost and initiate an } \\
\text { action plan for capacity-building } \\
\text { of private sector agro-dealers in } \\
\text { input procurement and } \\
\text { distribution, particularly at } \\
\text { decentralized levels }\end{array}$ & $\begin{array}{l}\text { An action plan } \\
\text { for capacity- } \\
\text { building of } \\
\text { private sector } \\
\text { agro-dealers was } \\
\text { drafted and } 400 \\
\text { agro-dealers } \\
\text { have received } \\
\text { training }\end{array}$ \\
\hline & & $\begin{array}{l}1.5 .4 \text { Farm } \\
\text { households } \text { to } \\
\text { extension ratio }\end{array}$ & $1: 2,218$ & $1: 2: 600$ & $1: 2,218$ & $\begin{array}{l}\text { Roll-out private and } \\
\text { public extensionists } \\
\text { across Districts }\end{array}$ & $\begin{array}{l}\text { Start Implementation of } \\
\text { Decentralized National } \\
\text { Agricultural Extension Strategy }\end{array}$ & $\begin{array}{l}\text { The extension } \\
\text { strategy was } \\
\text { adopted by the } \\
\text { Cabinet in } \\
\text { March 2009, and } \\
\text { the } \\
\text { implementation } \\
\text { of this strategy } \\
\text { has begun in } 11 \\
\text { districts }\end{array}$ \\
\hline
\end{tabular}

CInternational Monetary Fund. Not for Redistribution 


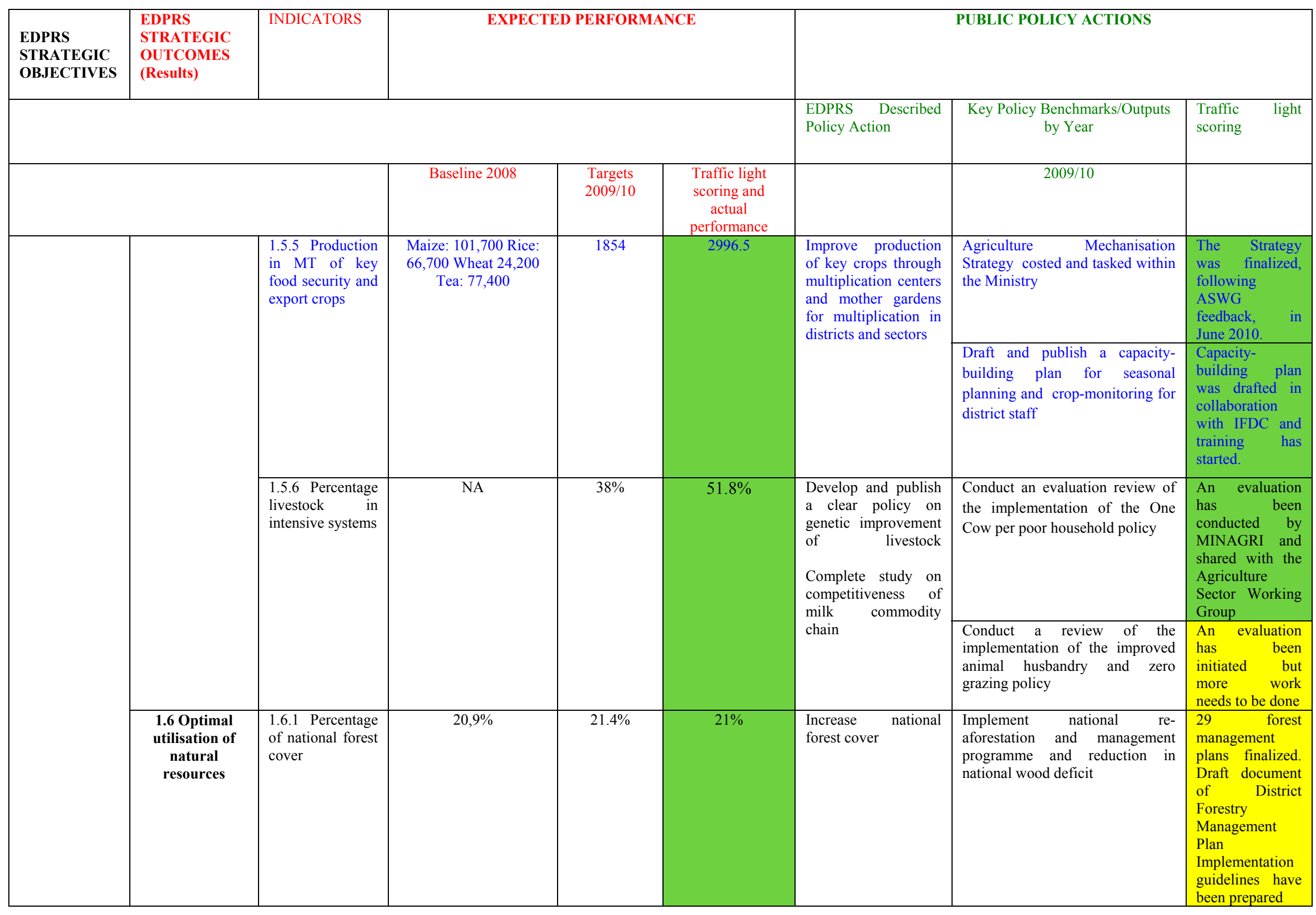




\begin{tabular}{|c|c|c|c|c|c|c|c|c|}
\hline $\begin{array}{l}\text { EDPRS } \\
\text { STRATEGIC } \\
\text { OBJECTIVES }\end{array}$ & $\begin{array}{l}\text { EDPRS } \\
\text { STRATEGIC } \\
\text { OUTCOMES } \\
\text { (Results) }\end{array}$ & INDICATORS & \multicolumn{3}{|c|}{ EXPECTED PERFORMANCE } & \multicolumn{3}{|c|}{ PUBLIC POLICY ACTIONS } \\
\hline & & & & & & $\begin{array}{l}\text { EDPRS Described } \\
\text { Policy Action }\end{array}$ & $\begin{array}{l}\text { Key Policy Benchmarks/Outputs } \\
\text { by Year }\end{array}$ & $\begin{array}{ll}\text { Traffic } \\
\text { scoring }\end{array} \quad$ light \\
\hline & & & Baseline 2008 & $\begin{array}{c}\text { Targets } \\
2009 / 10\end{array}$ & $\begin{array}{l}\text { Traffic light } \\
\text { scoring and } \\
\text { actual } \\
\text { performance }\end{array}$ & & $2009 / 10$ & \\
\hline & & $\begin{array}{l}1.6 .2 \text { Percentage } \\
\text { of area of } \\
\text { privately owned } \\
\text { land held under } \\
\text { written title }\end{array}$ & $1.26 \%$ & $10 \%$ & $19.3 \%$ & $\begin{array}{lr}\text { Protect land rights } \\
\text { and simplify land } \\
\text { administration ro to } \\
\text { facilitate investments } \\
\text { in land }\end{array}$ & $\begin{array}{l}\text { Develop the National Land use } \\
\text { master plans to guide land use } \\
\text { management decisions }\end{array}$ & 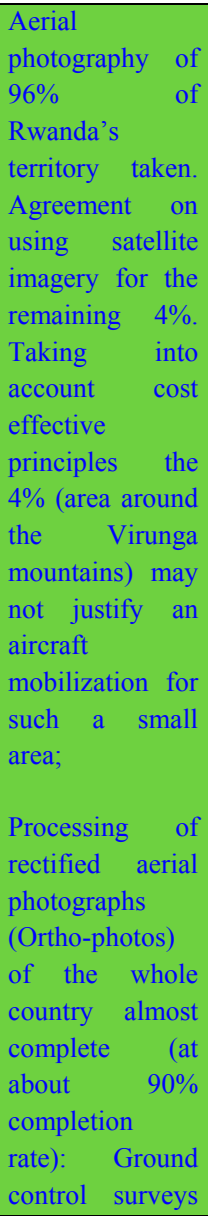 \\
\hline
\end{tabular}




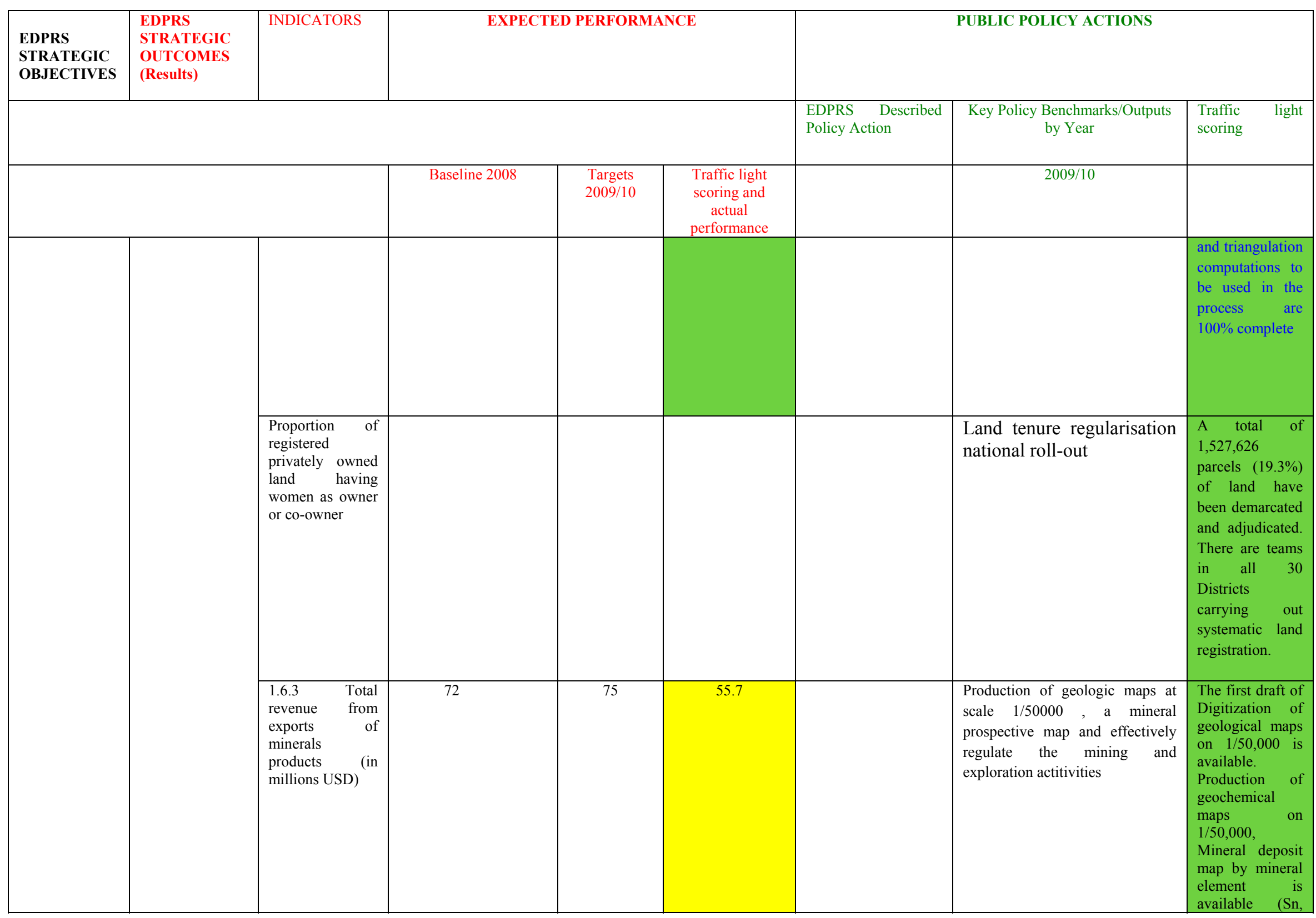




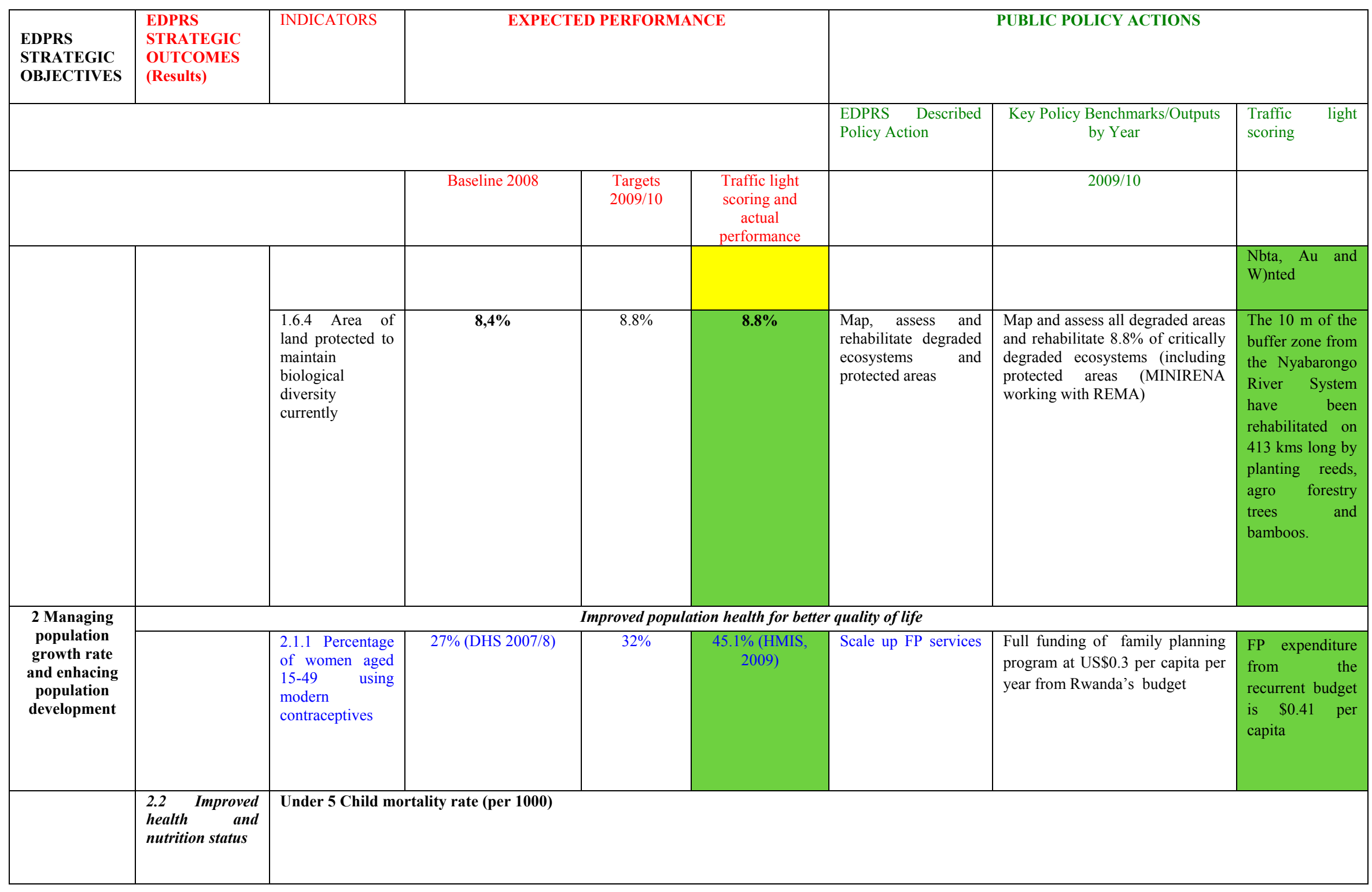




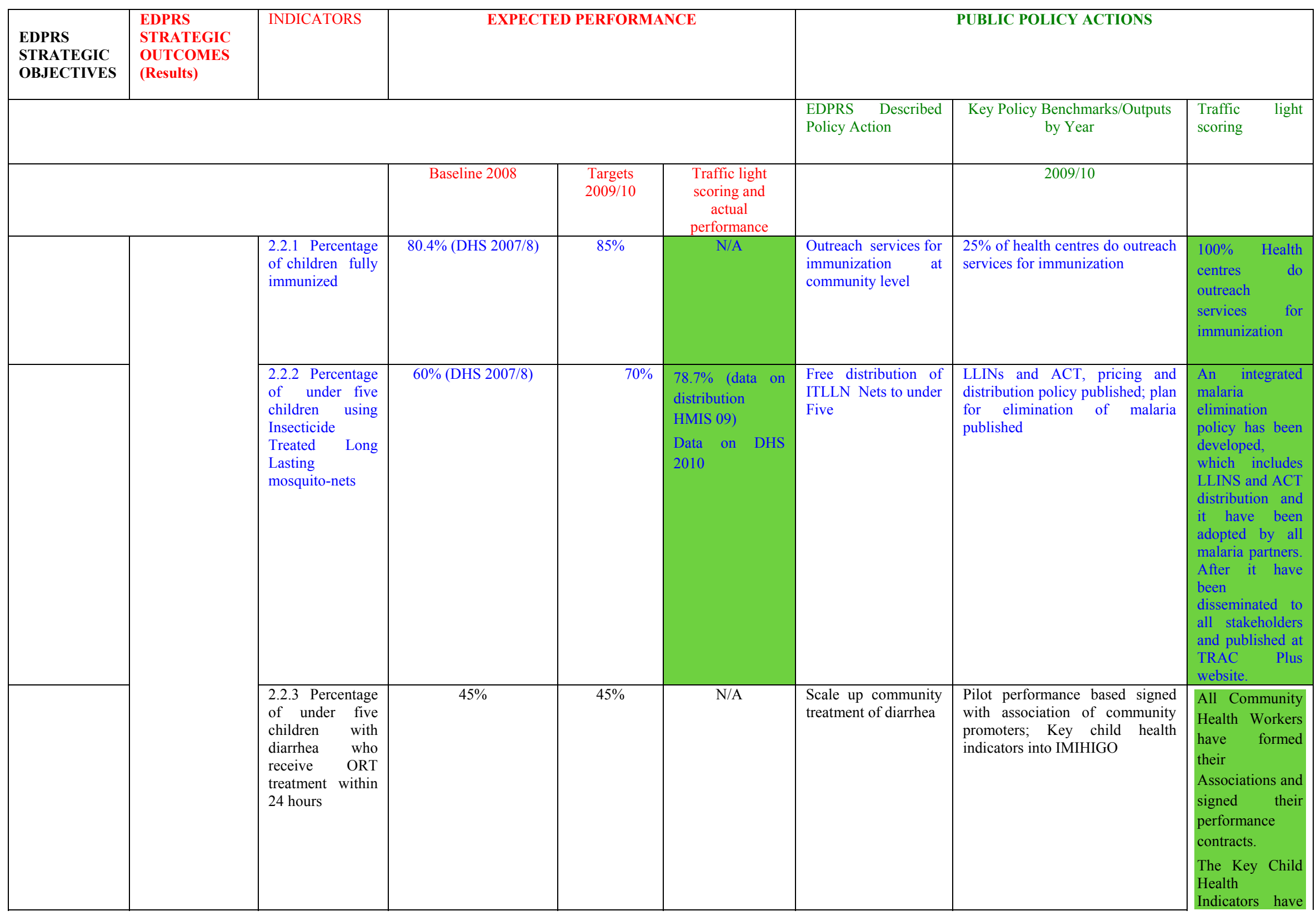

CInternational Monetary Fund. Not for Redistribution 


\begin{tabular}{|c|c|c|c|c|c|c|c|c|}
\hline \multirow{6}{*}{$\begin{array}{l}\text { EDPRS } \\
\text { STRATEGIC } \\
\text { OBJECTIVES }\end{array}$} & EDPRS & INDICATORS & \multicolumn{3}{|c|}{ EXPECTED PERFORMANCE } & \multicolumn{3}{|c|}{ PUBLIC POLICY ACTIONS } \\
\hline & & & & & & \multirow[t]{2}{*}{$\begin{array}{l}\text { EDPRS Described } \\
\text { Policy Action }\end{array}$} & \multirow[t]{2}{*}{$\begin{array}{l}\text { Key Policy Benchmarks/Outputs } \\
\text { by Year }\end{array}$} & \multirow[t]{2}{*}{$\begin{array}{ll}\begin{array}{l}\text { Traffic } \\
\text { scoring }\end{array} & \text { light } \\
\end{array}$} \\
\hline & & & Baseline 2008 & $\begin{array}{l}\text { Targets } \\
2009 / 10\end{array}$ & $\begin{array}{l}\text { Traffic light } \\
\text { scoring and } \\
\text { actual } \\
\text { performance } \\
\end{array}$ & & & \\
\hline & & & & & & & & $\begin{array}{l}\text { been included } \\
\text { into the } \\
\text { IMIHIGO for all } \\
\text { Districts. }\end{array}$ \\
\hline & & \multicolumn{7}{|c|}{ Maternal Mortality rate (per 100,000 live births) } \\
\hline & & $\begin{array}{l}2.2 .4 \text { Percentage } \\
\text { of assisted births } \\
\text { in an accredited } \\
\text { health facility }\end{array}$ & $62,8 \%$ & $40 \%$ & $66.2 \%$ (HMIS 09) & $\begin{array}{l}\text { Develop incentive } \\
\text { mechanisms to } \\
\text { increase deliveries in } \\
\text { health facilities }\end{array}$ & $\begin{array}{l}\text { Increase price of PBF for assisted } \\
\text { deliveries by } 50 \% \text { and implement } \\
\text { conditional cash transfers for } \\
\text { assisted deliveries in pilot districts }\end{array}$ & $\begin{array}{l}\text { PBF for assisted } \\
\text { delivery is to be } \\
\text { increased to } \\
50 \% \text { in all health } \\
\text { facilities in } \\
2010- \\
\text { budget. } \\
\text { However, this } \\
\text { process has been } \\
\text { piloted in } 4 \\
\text { districts of } \\
\text { Nyamagabe, } \\
\text { Rutsiro, } \\
\text { Gakenke and } \\
\text { Kirehe starting } \\
\text { in the second } \\
\text { quarter of 2008- } \\
2009 \text { budget: } \\
\end{array}$ \\
\hline & & \multicolumn{7}{|c|}{ Nutrition:\% of children who have chronic malnutrition } \\
\hline
\end{tabular}




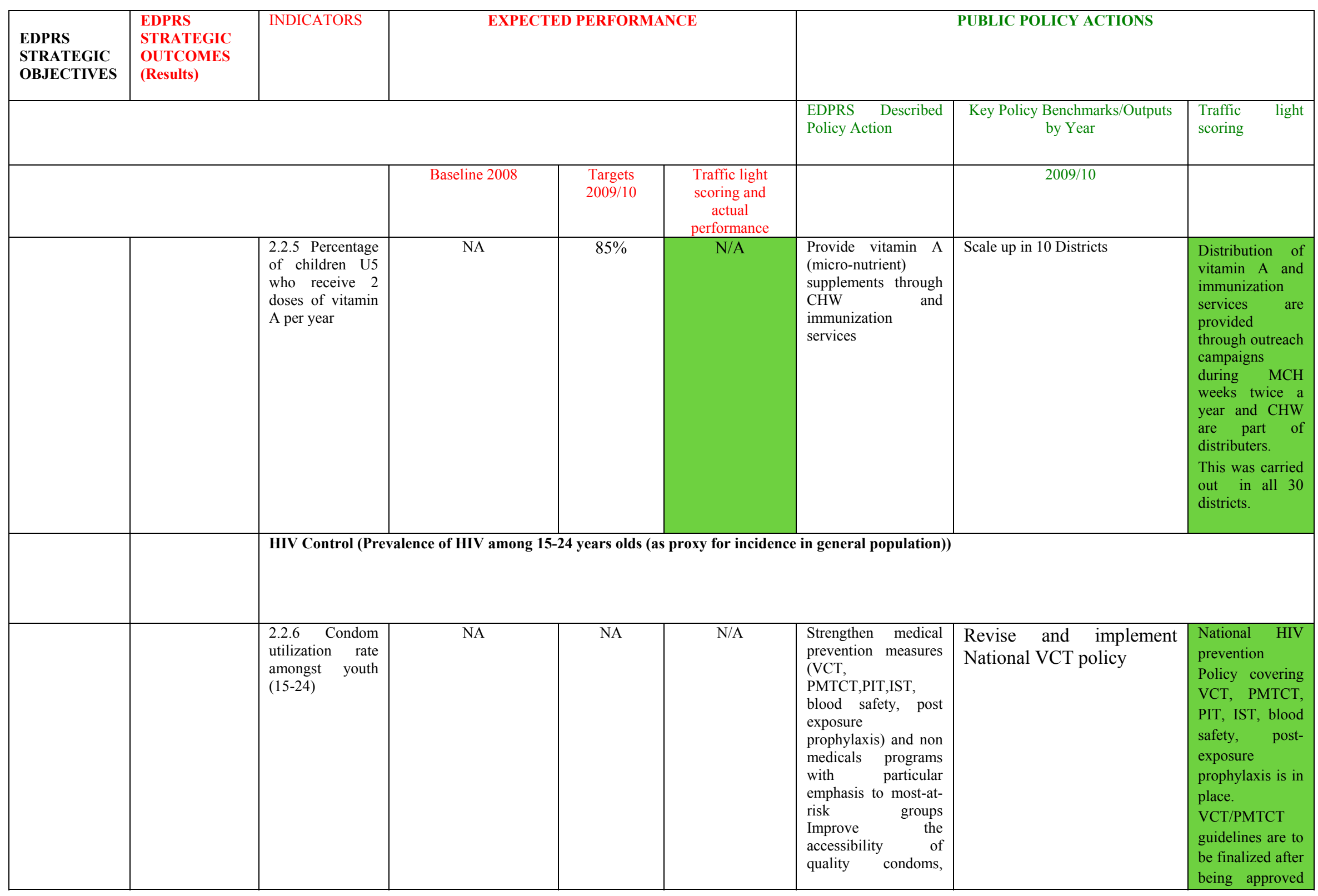




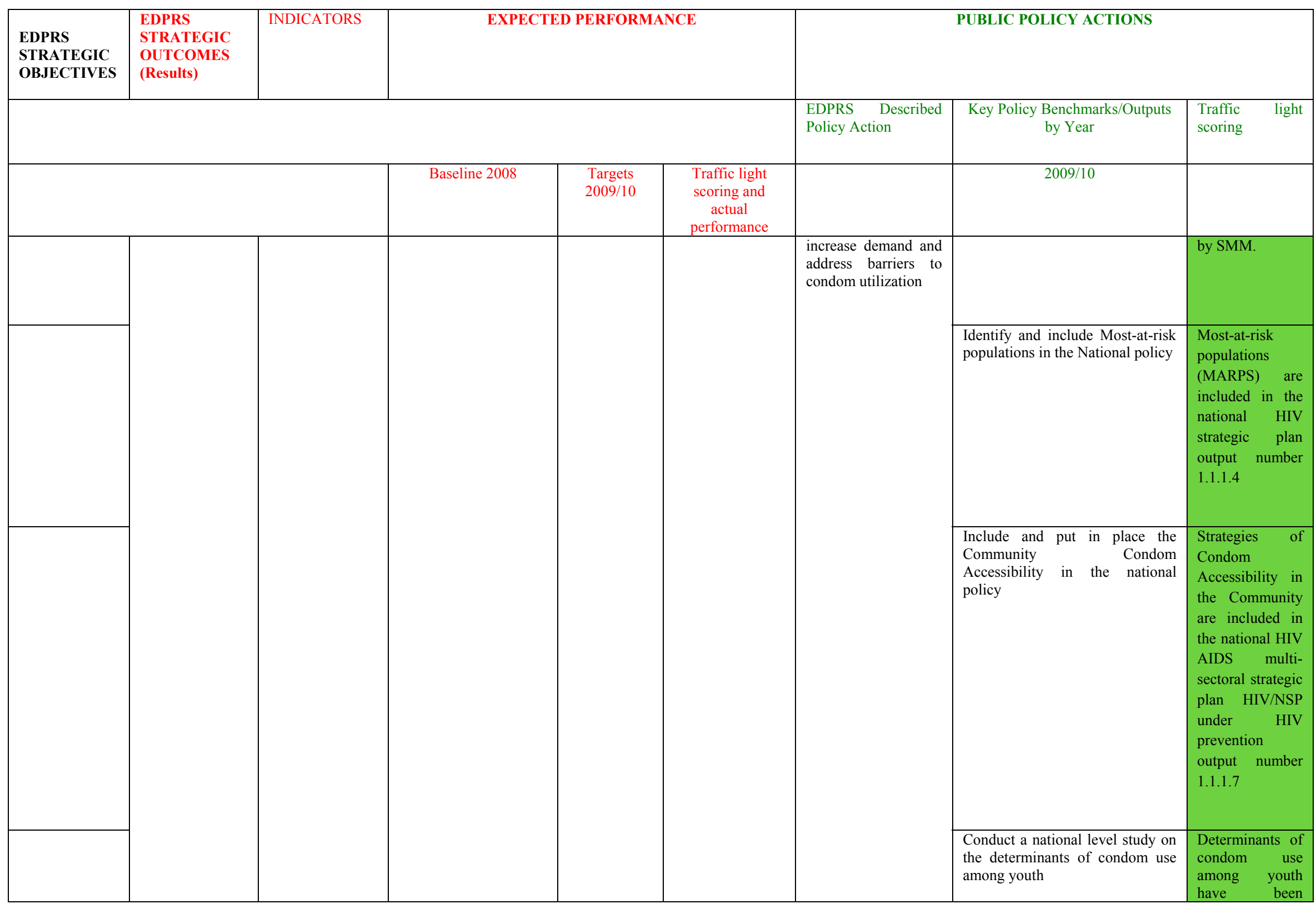




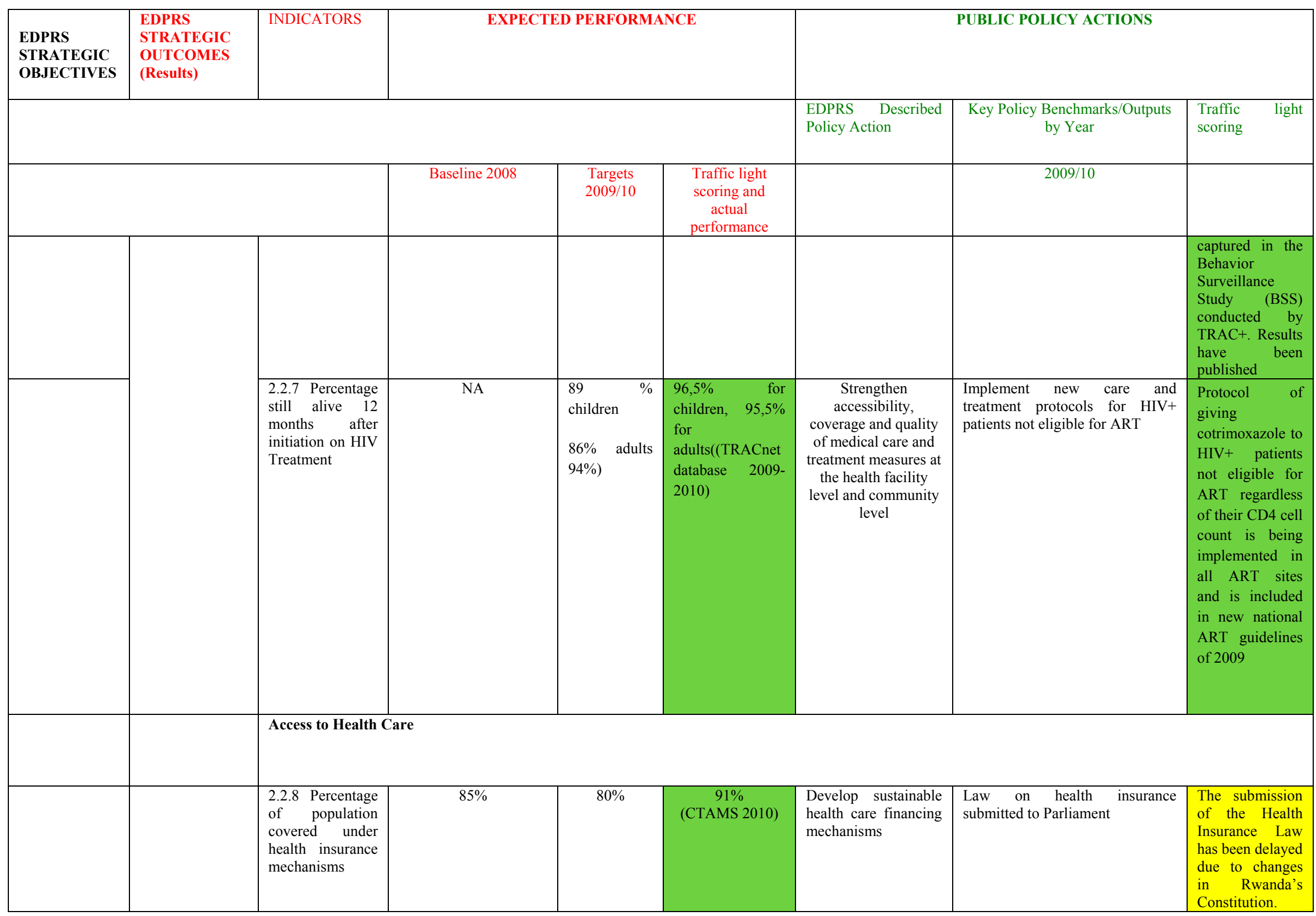




\begin{tabular}{|c|c|c|c|c|c|c|c|c|}
\hline $\begin{array}{l}\text { EDPRS } \\
\text { STRATEGIC } \\
\text { OBJECTIVES }\end{array}$ & EDPRS & INDICATORS & \multicolumn{3}{|c|}{ EXPECTED PERFORMANCE } & \multicolumn{3}{|c|}{ PUBLIC POLICY ACTIONS } \\
\hline & & & & & & Policy Action & $\begin{array}{l}\text { by Year } \\
\text {. }\end{array}$ & scoring \\
\hline & & & Baseline 2008 & $\begin{array}{l}\text { Targets } \\
2009 / 10\end{array}$ & $\begin{array}{l}\text { Traffic light } \\
\text { scoring and } \\
\text { actual } \\
\text { performance }\end{array}$ & & $2009 / 10$ & \\
\hline & & & & & & & & $\begin{array}{l}\text { The re-drafted } \\
\text { Health Insurance } \\
\text { Law, taking into } \\
\text { account the } \\
\text { Constitutional } \\
\text { changes will be } \\
\text { submitted to } \\
\text { Cabinet and then } \\
\text { to the } \\
\text { Parliament. }\end{array}$ \\
\hline & & 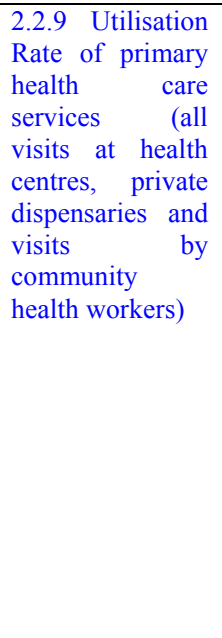 & 0.86 (HMIS 2008) & 0.8 & 0.95 (HMIS 2009) & $\begin{array}{l}\text { Reduce barriers to } \\
\text { utilisation of services }\end{array}$ & $\begin{array}{l}\text { Pilot reducing } \\
\text { moderateur" and ind introducing } \\
\text { conditional cash transfers for } \\
\text { children less than } 5 \text { and pregnant } \\
\text { women }\end{array}$ & $\begin{array}{l}\text { Pregnant women } \\
\text { are exempted } \\
\text { from paying } \\
\text { "ticket } \\
\text { moderateur". } \\
\text { For children } \\
\text { under } 5 \text { years } \\
\text { "ticket } \\
\text { moderateur" has } \\
\text { been removed in } \\
2 \text { pilot districts } \\
\text { of Muhanga } \\
\text { District } \\
\text { (Muremure HC) } \\
\text { and in Kicukiro } \\
\text { District(Gahang } \\
\text { a HC). }\end{array}$ \\
\hline
\end{tabular}




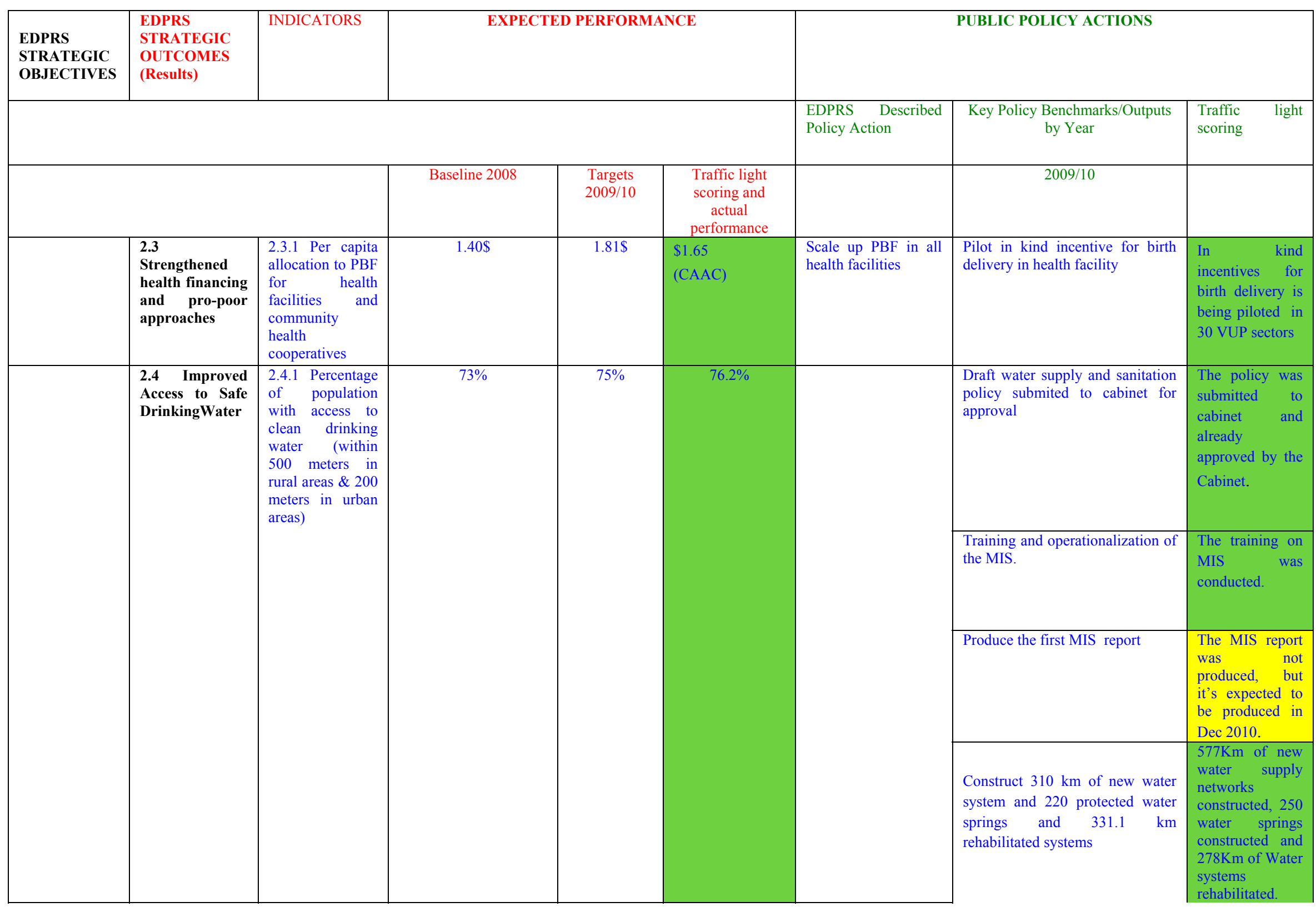




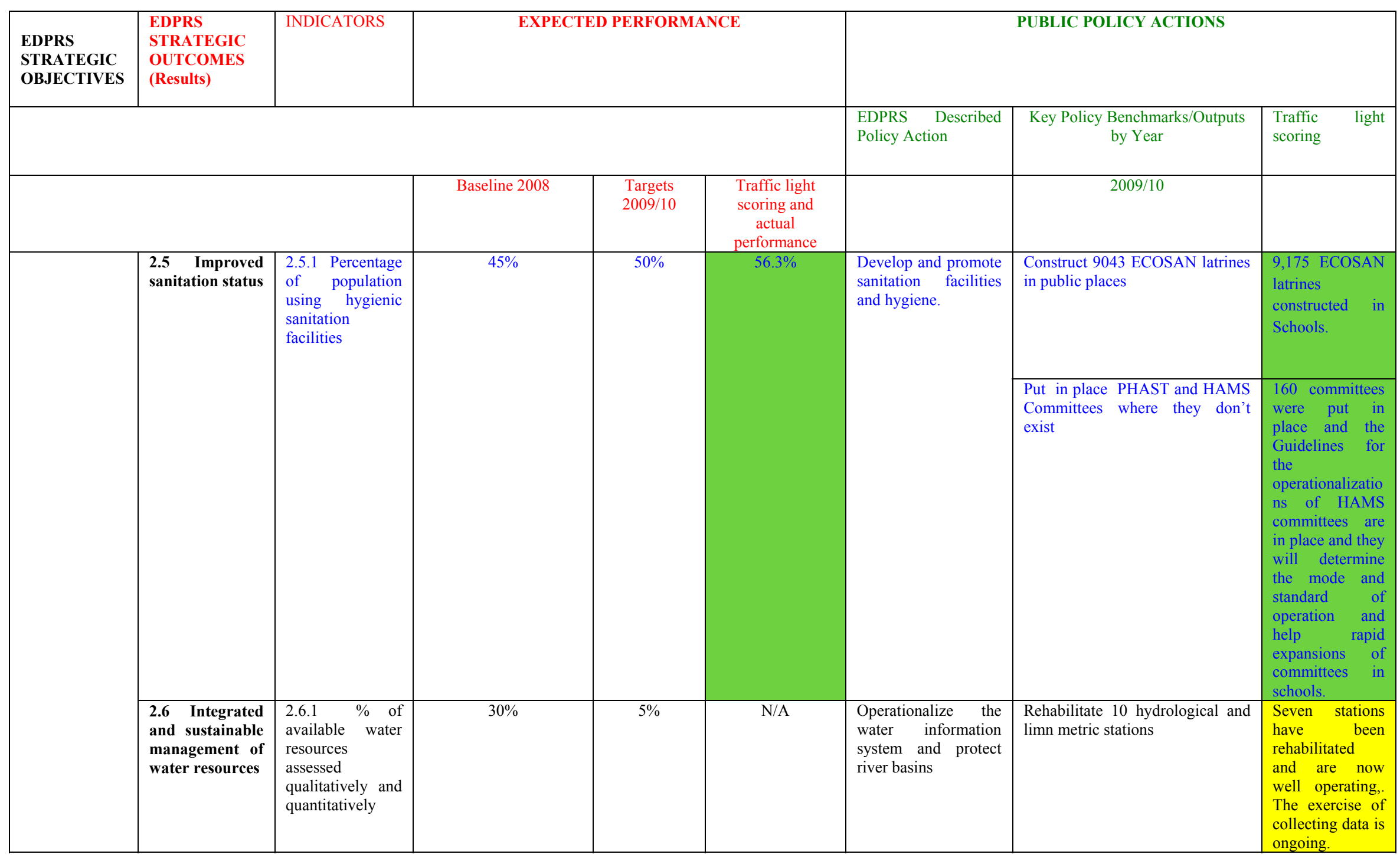




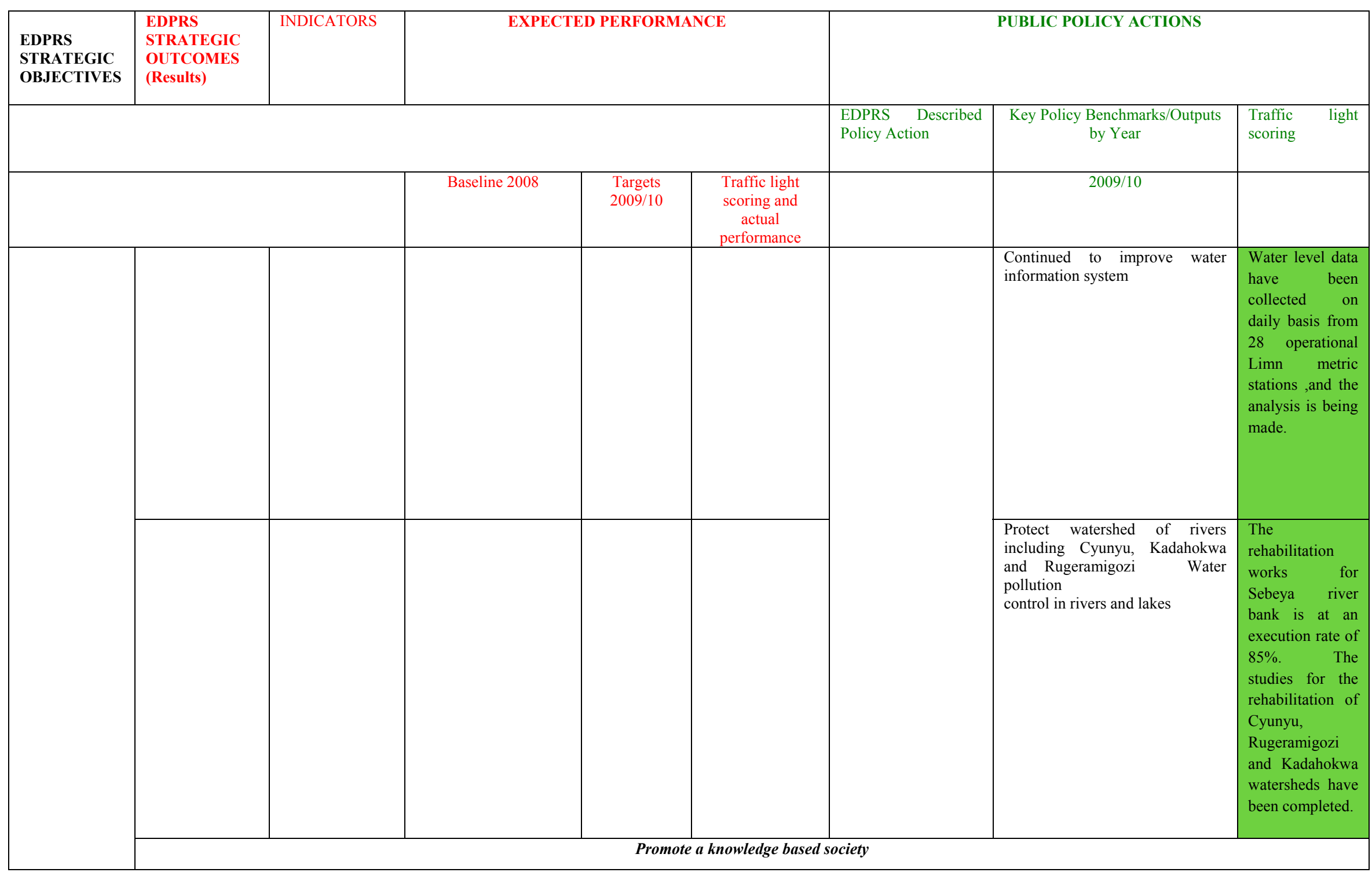




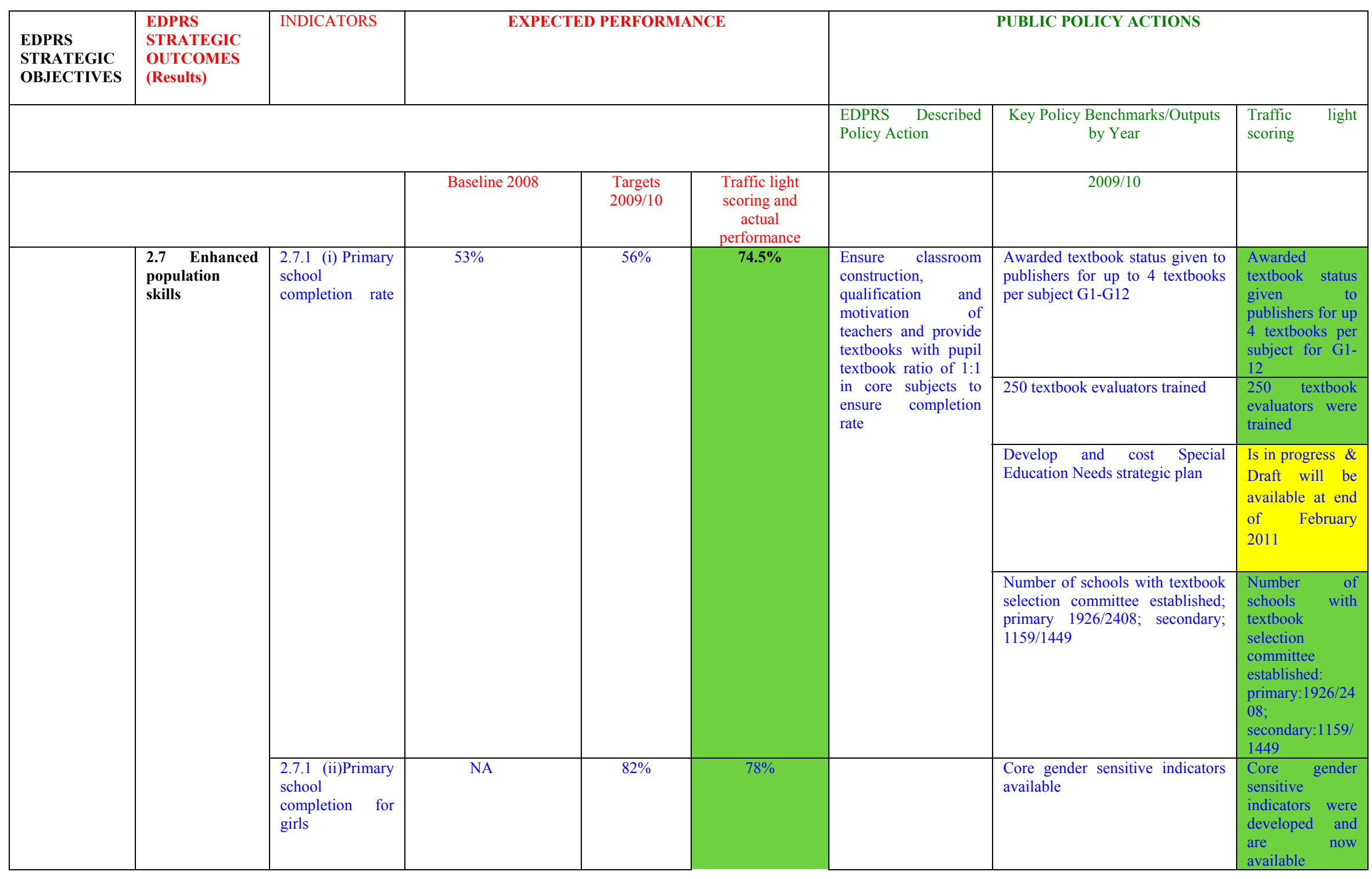




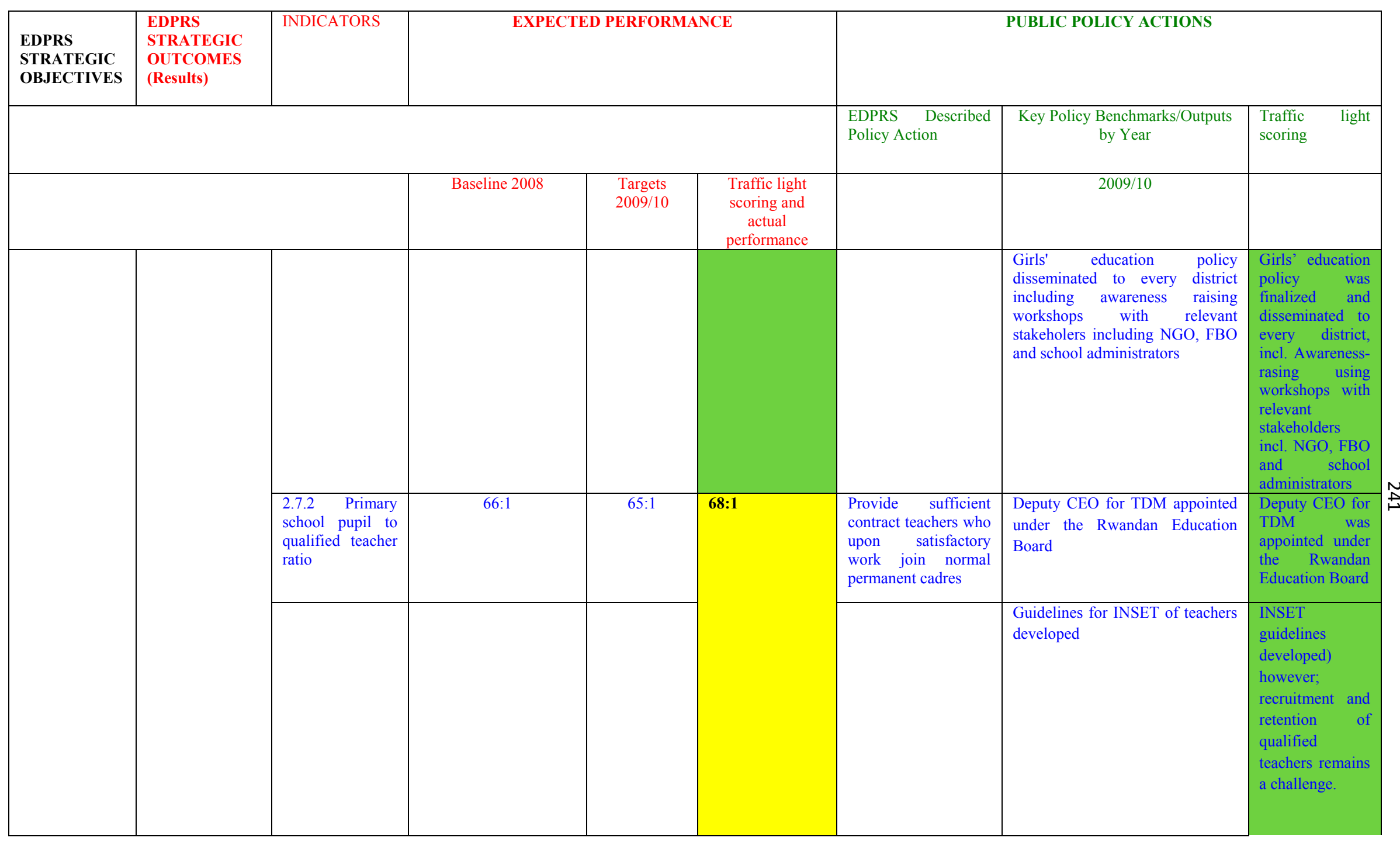




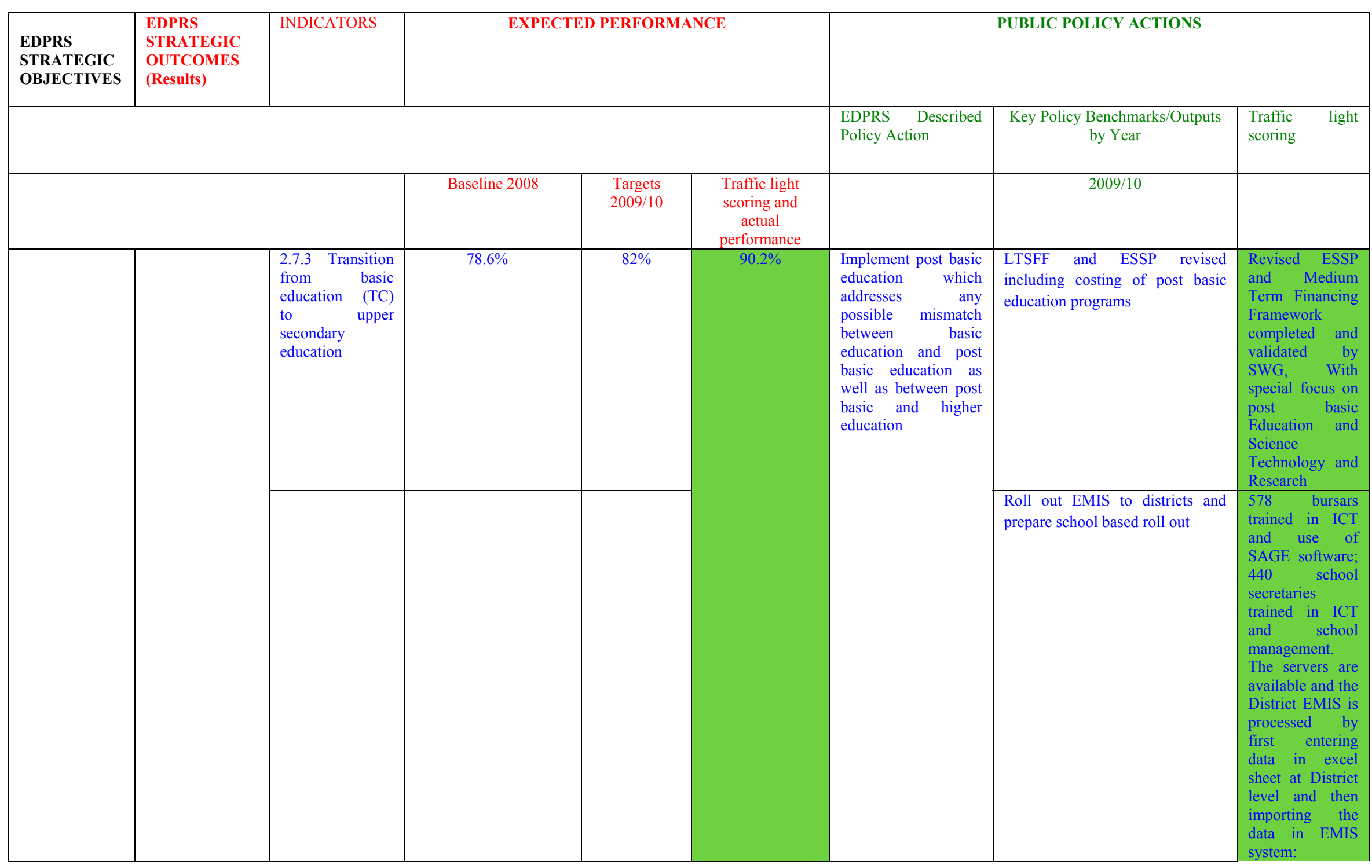




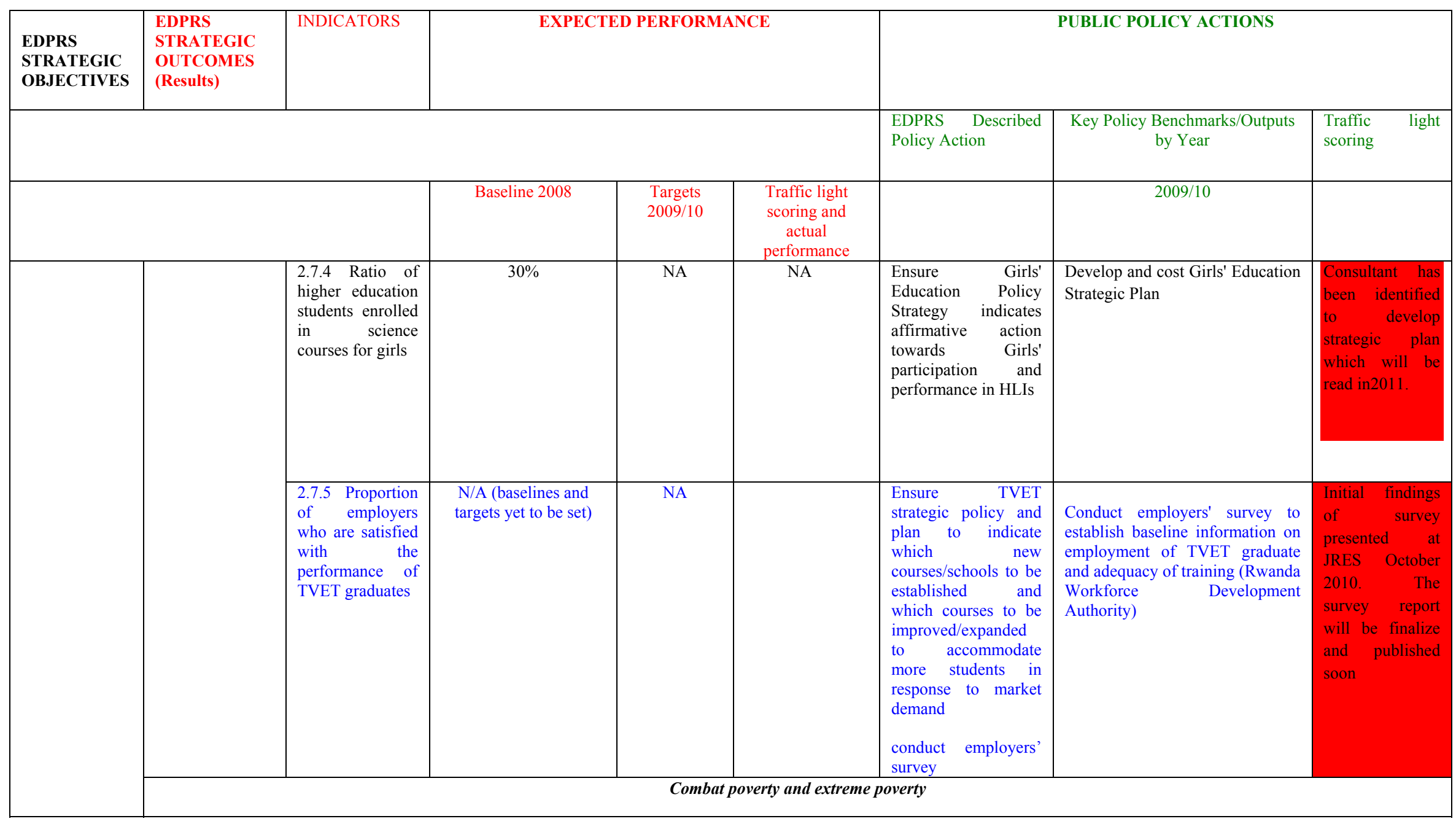




\begin{tabular}{|c|c|c|c|c|c|c|c|c|}
\hline $\begin{array}{l}\text { EDPRS } \\
\text { STRATEGIC } \\
\text { OBJECTIVES }\end{array}$ & $\begin{array}{l}\text { EDPRS } \\
\text { STRATEGIC } \\
\text { OUTCOMES } \\
\text { (Results) }\end{array}$ & INDICATORS & \multicolumn{3}{|c|}{ EXPECTED PERFORMANCE } & \multicolumn{3}{|c|}{ PUBLIC POLICY ACTIONS } \\
\hline & & & & & & $\begin{array}{l}\text { EDPRS Described } \\
\text { Policy Action }\end{array}$ & $\begin{array}{l}\text { Key Policy Benchmarks/Outputs } \\
\text { by Year }\end{array}$ & $\begin{array}{ll}\text { Traffic } & \text { light } \\
\text { scoring } & \end{array}$ \\
\hline & & & 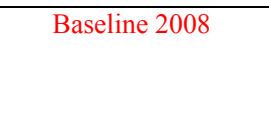 & $\begin{array}{l}\text { Targets } \\
2009 / 10\end{array}$ & $\begin{array}{l}\text { Traffic light } \\
\text { scoring and } \\
\text { actual } \\
\text { performance }\end{array}$ & & $2009 / 10$ & \\
\hline & $\begin{array}{lr}2.8 & \text { Improved } \\
\text { Social } & \text { Safety } \\
\text { Net } & \\
\end{array}$ & $\begin{array}{l}2.8 .1 \quad \text { (i) The } \\
\text { percentage of } \\
\text { households in the } \\
\text { bottom two } \\
\text { categories of } \\
\text { extreme poverty } \\
\text { according to } \\
\text { UBUDEHE } \\
\text { classification (ii) } \\
\text { The poverty-gap } \\
\text { index }\end{array}$ & Target to be set (N/A) & NA & $\mathrm{N} / \mathrm{A}$ & $\begin{array}{l}\text { Government to begin } \\
\text { to implement and } \\
\text { operationalize the } \\
\text { VUP Policy } \\
\text { Framework in the } 30 \\
\text { pilot districts }\end{array}$ & $\begin{array}{l}\text { Government has committed } \\
\text { budget allocations to implement } \\
\text { the VUP program in at least } 30 \\
\text { pilot sectors and ensured } \\
\text { coordination of all social } \\
\text { protection activities, in } \\
\text { accordance with National Social } \\
\text { Protection Policy }\end{array}$ & $\begin{array}{l}\text { Fully } \\
\text { implemented. } \\
\text { Sufficient } \\
\text { budget allocated. } \\
\text { VUP was } \\
\text { implemented in } \\
60 \text { sectors } \\
\text { (surpassed } \\
\text { target). VUP } \\
\text { coordinated with } \\
\text { other SP } \\
\text { activities at the } \\
\text { sector and } \\
\text { district levels. }\end{array}$ \\
\hline & & $\begin{array}{l}2.8 .2 . \% \text { of } \\
\text { households } \\
\text { eligible } \\
\text { support, } \\
\text { granted } \\
\text { works }\end{array}$ & $35 \%$ & $35 \%$ & $\begin{array}{l}91 \% \text { of eligible } \\
\text { households were } \\
\text { employed in PW }\end{array}$ & $\begin{array}{lr}\text { Establish } & \text { and } \\
\text { implement a Public } \\
\text { Works } & \text { policy } \\
\text { framework } & \\
\text { (incorporating good } \\
\text { international practice) } \\
\text { underpinned by } \\
\text { training at local } \\
\text { government level. }\end{array}$ & $\begin{array}{l}\text { Scale up public works in } \\
\text { according to international good } \\
\text { practice in respect of: wage rates } \\
\text { (ration to market wage less than } \\
\text { 1); community selection of } \\
\text { projects; voluntary savings and } \\
\text { direct payment of wages, and with } \\
\text { budget allocations reflecting } \\
\text { EDPRS priorities. }\end{array}$ & $\begin{array}{l}\text { Fully } \\
\text { implemented. } \\
\text { Wage rates less } \\
\text { than or equal to } \\
\text { one in all but } 2 \\
\text { sectors, where } \\
\text { remedial action } \\
\text { taken. } \\
\text { Communities } \\
\text { are involved in } \\
\text { project selection } \\
\text { through sector } \\
\text { development } \\
\text { plans. Savings } \\
\text { are voluntary. } \\
\text { Wages are paid } \\
\text { direct into } \\
\text { beneficiary } \\
\text { household bank } \\
\text { accounts and not } \\
\text { through } \\
\text { contractors. }\end{array}$ \\
\hline
\end{tabular}




\begin{tabular}{|c|c|c|c|c|c|c|c|c|}
\hline $\begin{array}{l}\text { EDPRS } \\
\text { STRATEGIC } \\
\text { OBJECTIVES }\end{array}$ & EDPRS & INDICATORS & \multicolumn{3}{|c|}{ EXPECTED PERFORMANCE } & \multicolumn{3}{|c|}{ PUBLIC POLICY ACTIONS } \\
\hline & & & & & & $\begin{array}{l}\text { EDPRS Described } \\
\text { Policy Action }\end{array}$ & $\begin{array}{c}\text { Key Policy Benchmarks/Outputs } \\
\text { by Year }\end{array}$ & $\begin{array}{l}\text { Traffic light } \\
\text { scoring }\end{array}$ \\
\hline & & & Baseline 2008 & $\begin{array}{l}\text { Targets } \\
2009 / 10\end{array}$ & $\begin{array}{l}\text { Traffic light } \\
\text { scoring and } \\
\text { actual } \\
\text { performance }\end{array}$ & & $2009 / 10$ & \\
\hline & & $\begin{array}{l}2.8 .3 \text { of those } \\
\text { households } \\
\text { eligible for } \\
\text { support, } \% \\
\text { granted direct } \\
\text { support in } \\
\text { sector }\end{array}$ & NA & $60 \%$ & $\begin{array}{l}100 \% \text { of all } \\
\text { eligible } \\
\text { households were } \\
\text { given DS }\end{array}$ & $\begin{array}{l}\text { Incorporate direct } \\
\text { support activities } \\
\text { into all district and } \\
\text { imirenge plans, and } \\
\text { in JADFs at District } \\
\text { and Umurenge level }\end{array}$ & $\begin{array}{l}\text { Scale up VUP direct supports } \\
\text { according to international good } \\
\text { practice and ensure coordination } \\
\text { of all social protection activities } \\
\text { in accordance with the national } \\
\text { social protection policy. }\end{array}$ & $\begin{array}{l}\text { Fully } \\
\text { implemented. } \\
\text { The VUP } \\
\text { targeting process } \\
\text { is transparent - } \\
\text { village meetings } \\
\text { are held each } \\
\text { year in } \\
\text { May/June to } \\
\text { publically } \\
\text { update the } \\
\text { targeting list } \\
\text { information } \\
\text { (household } \\
\text { Ubudehe } \\
\text { category, land } \\
\text { and labour). } \\
\text { Lists of DS } \\
\text { eligible } \\
\text { households are } \\
\text { then publically } \\
\text { posted. } \\
\text { Timeliness of } \\
\text { payments has } \\
\text { improved from } \\
\text { the previous } \\
\text { year, with more } \\
\text { efficient } \\
\text { quarterly } \\
\text { disbursement } \\
\text { systems being } \\
\text { used. VUP is } \\
\text { coordinated }\end{array}$ \\
\hline
\end{tabular}




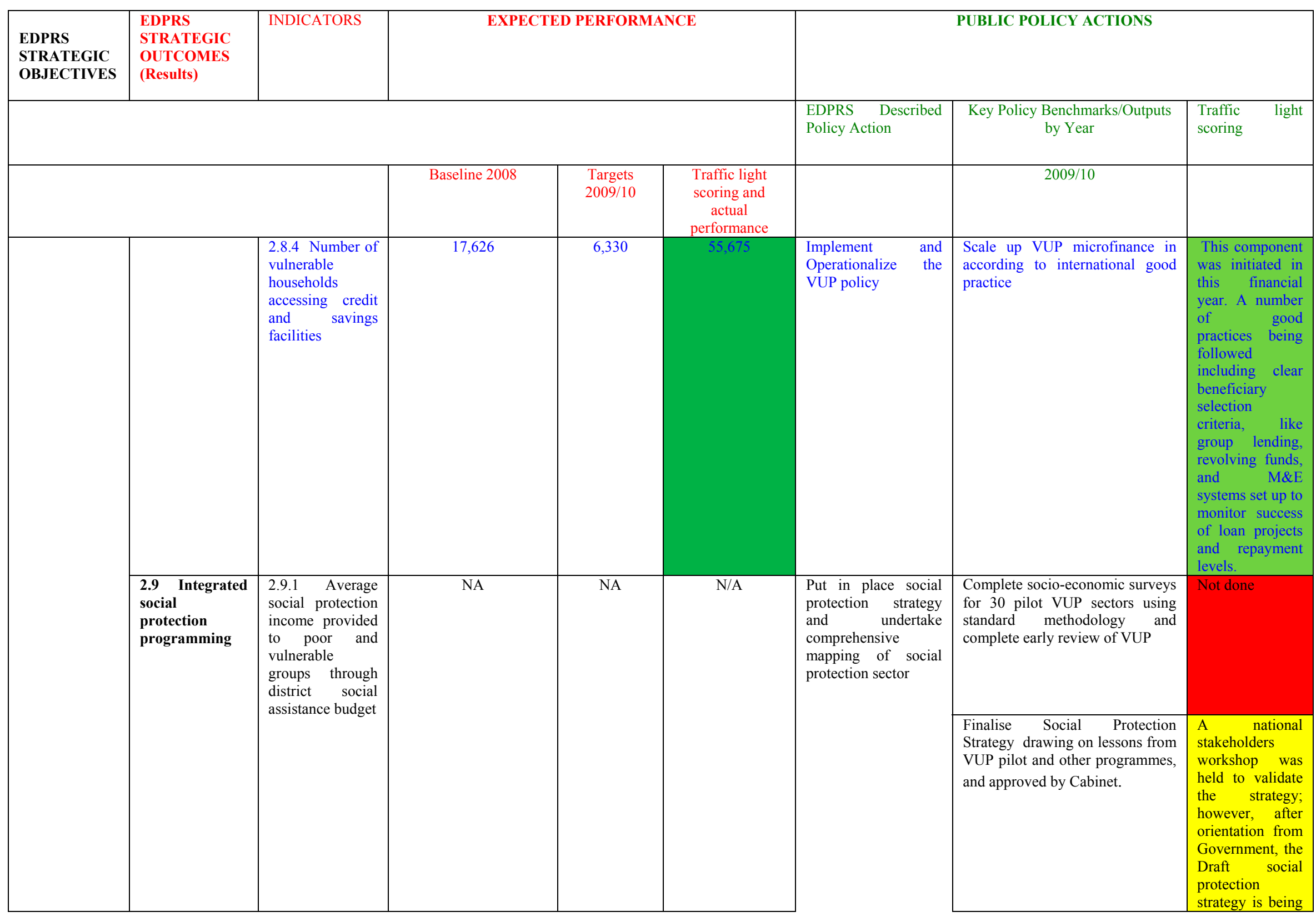




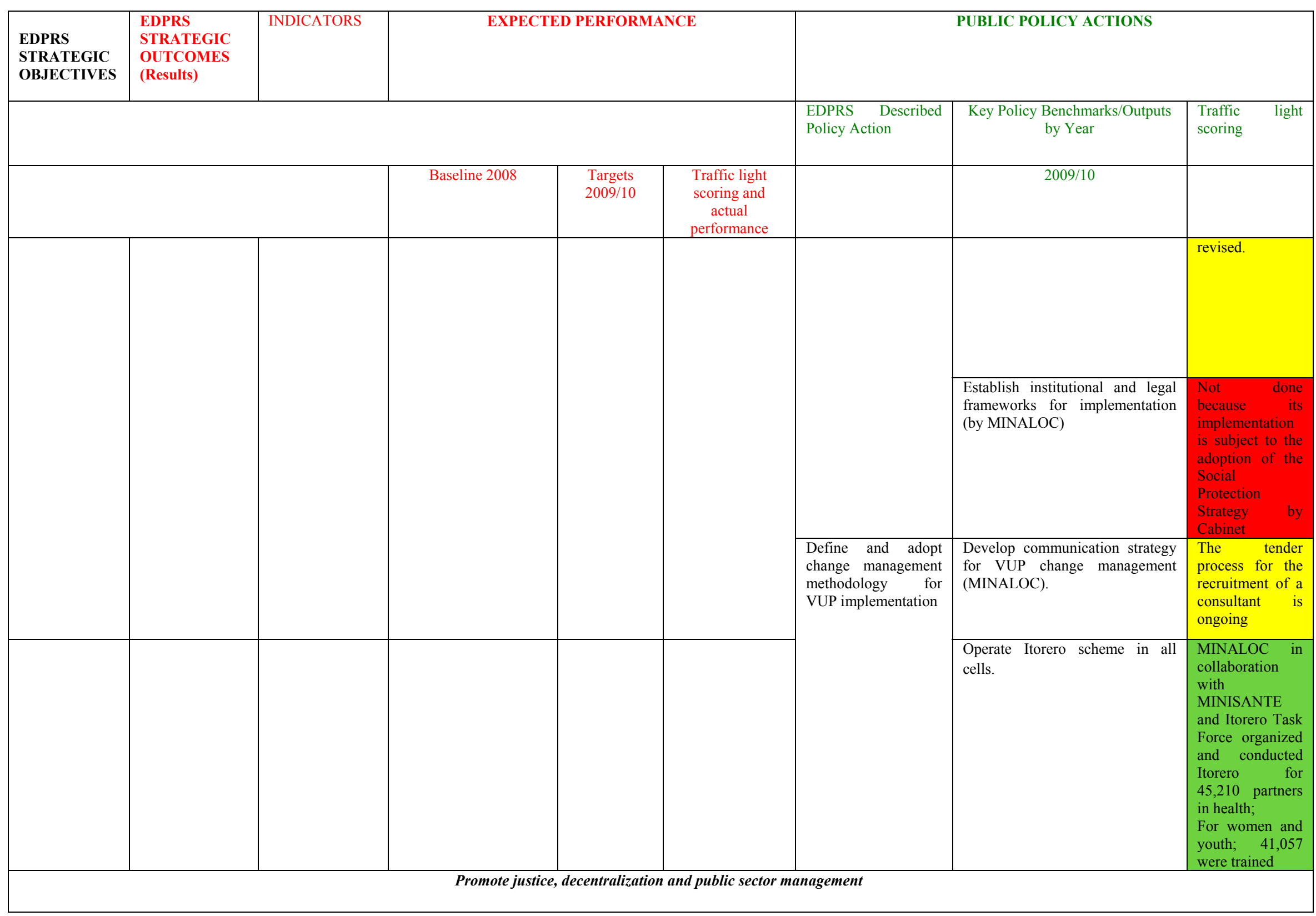




\begin{tabular}{|c|c|c|c|c|c|c|c|c|}
\hline \multirow{2}{*}{$\begin{array}{l}\text { EDPRS } \\
\text { STRATEGIC } \\
\text { OBJECTIVES }\end{array}$} & \multirow{2}{*}{$\begin{array}{l}\text { EDPRS } \\
\text { STRATEGIC } \\
\text { OUTCOMES } \\
\text { (Results) }\end{array}$} & \multirow[t]{2}{*}{ INDICATORS } & & \\
\hline & & & \multicolumn{3}{|c|}{ EXPECTED PERFORMANCE } & \multicolumn{2}{|c|}{\begin{tabular}{l|c}
\multicolumn{4}{c}{ PUBLIC POLICY ACTIONS } \\
\multicolumn{2}{l}{} \\
$\begin{array}{l}\text { EDPRS Described } \\
\text { Policy Action }\end{array}$ & $\begin{array}{l}\text { Key Policy Benchmarks/Outputs } \\
\text { by Year }\end{array}$
\end{tabular}} & $\begin{array}{ll}\text { Traffic light } \\
\text { scoring }\end{array}$ \\
\hline & & & Baseline 2008 & $\begin{array}{l}\text { Targets } \\
2009 / 10\end{array}$ & $\begin{array}{l}\text { Traffic light } \\
\text { scoring and } \\
\text { actual } \\
\text { performance }\end{array}$ & & $2009 / 10$ & \\
\hline \multirow[t]{4}{*}{$\begin{array}{l}3 \text { Enhanced } \\
\text { gains through } \\
\text { good } \\
\text { governance }\end{array}$} & $\begin{array}{lr}3.1 & \text { Enhanced } \\
\text { partnership } \\
\text { between GoR, } \\
\text { Civil Society } \\
\text { and } & \text { Private } \\
\text { Sector. } & \end{array}$ & $\begin{array}{l}3.1 .1 \text { Percentage } \\
\text { of CSO and PS } \\
\text { representation in } \\
\text { JADF and } \\
\text { Decentralization } \\
\text { Cluster }\end{array}$ & $70 \%$ & $75 \%$ & $\begin{array}{l}\text { According to } \\
\text { JADF reports all } \\
\text { NGOs and CSOs } \\
\text { at local level are } \\
\text { members of the } \\
\text { JADF. }\end{array}$ & $\begin{array}{l}\text { Public, Private sector } \\
\text { and Civil Society } \\
\text { fully engaged in } \\
\text { successful } \\
\text { partnerships for } \\
\text { effective delivery of } \\
\text { good governance and } \\
\text { decentralization }\end{array}$ & $\begin{array}{l}\text { National policy on civil society } \\
\text { developed and adopted }\end{array}$ & $\begin{array}{l}\text { Policy was } \\
\text { developed in } \\
2006 \text { is not yet } \\
\text { updated }\end{array}$ \\
\hline & \multirow[t]{2}{*}{$\begin{array}{l}3.2 \text { Effective } \\
\text { coordination of } \\
\text { national labour } \\
\text { force }\end{array}$} & \multirow[t]{2}{*}{$\begin{array}{l}3.2 .1 \text { Number of } \\
\text { new non-farm } \\
\text { jobs created } \\
\text { (cumulative } \\
\text { target) } \\
\text { (indicative) } 3\end{array}$} & \multirow[t]{2}{*}{$N A$} & \multirow[t]{2}{*}{$N A$} & \multirow[t]{2}{*}{$N / A$} & $\begin{array}{l}\text { National employment } \\
\text { policy and strategy } \\
\text { disseminated and } \\
\text { implemented }\end{array}$ & $\begin{array}{l}\text { Seek approval of National } \\
\text { Employment Agency }\end{array}$ & $\begin{array}{l}\text { Kivu } \\
\text { Resolutions in } \\
\text { February } 2010 \\
\text { transferred the } \\
\text { activities to be } \\
\text { carried out by } \\
\text { National } \\
\text { Employment } \\
\text { Agency to RDB }\end{array}$ \\
\hline & & & & & & $\begin{array}{l}\begin{array}{l}\text { Strengthen } \\
\text { savings \& }\end{array} \\
\text { institutions } \\
\text { credit } \\
\text { enhance employment } \\
\text { of youths through } \\
\text { cooperatives } \\
\text { (MIJESPOC, } \\
\text { MINICOM, NYC \& } \\
\text { BNR) } \\
\end{array}$ & $\begin{array}{l}\text { Strengthen district wide } 5 \text { Youth } \\
\text { savings\&credit schemes }\end{array}$ & $\begin{array}{l}3 \text { COOJAD } \\
\text { branches of } \\
\text { Nyaruguru, } \\
\text { Remera and } \\
\text { Bugesera were } \\
\text { financially and } \\
\text { materially } \\
\text { supported }\end{array}$ \\
\hline & & & & & & & $\begin{array}{lll}\begin{array}{l}\text { Operationalise } \\
\text { cooperatives }\end{array} & 100 & \text { youth } \\
\end{array}$ & $\begin{array}{l}\text { Within the } \\
\text { process of } \\
\text { transforming } \\
\text { youth } \\
\text { associations into } \\
\text { cooperatives, } 24 \\
\text { cooperatives } \\
\text { were financially } \\
\text { supported } \\
\text { whereas } 43\end{array}$ \\
\hline
\end{tabular}




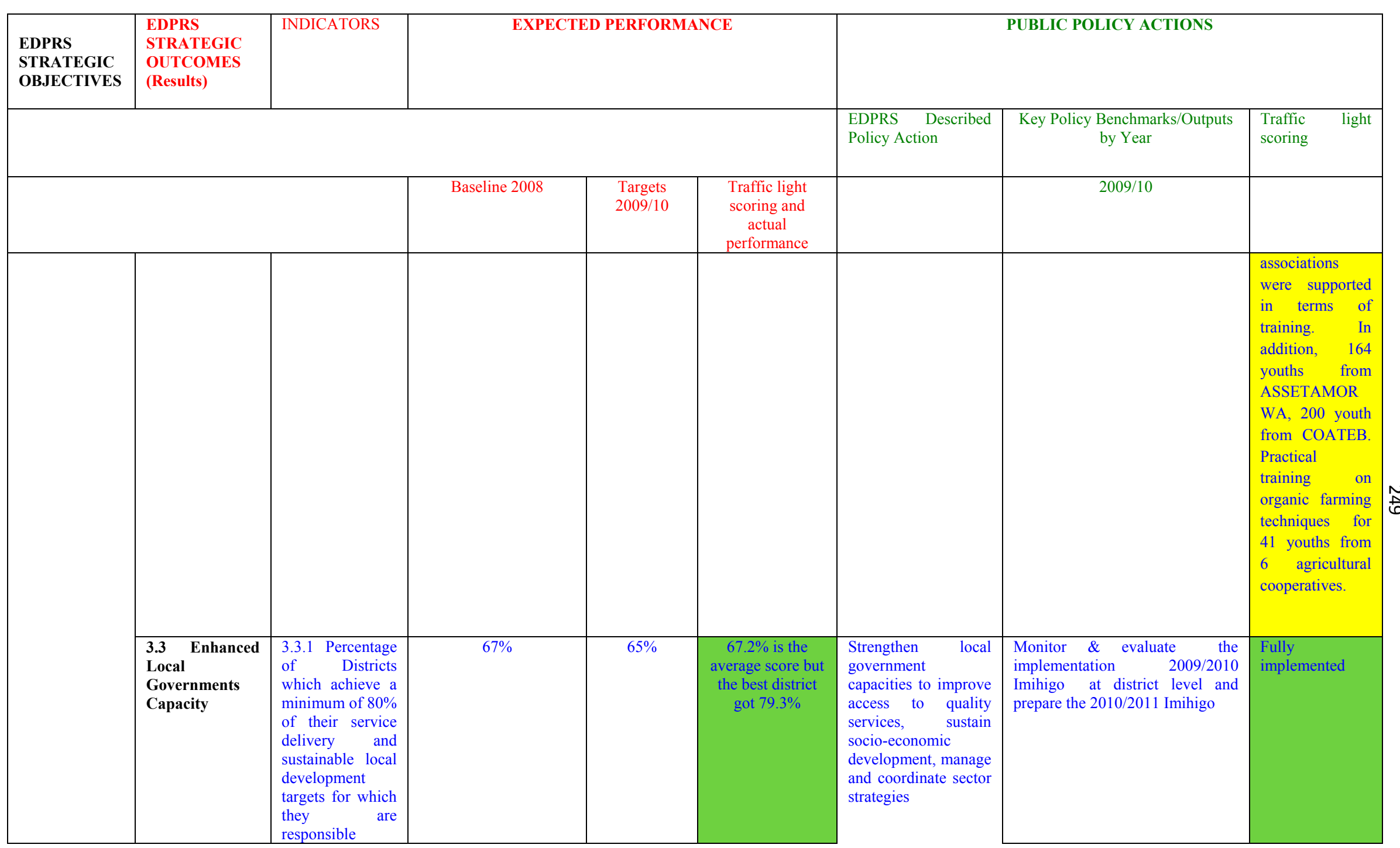




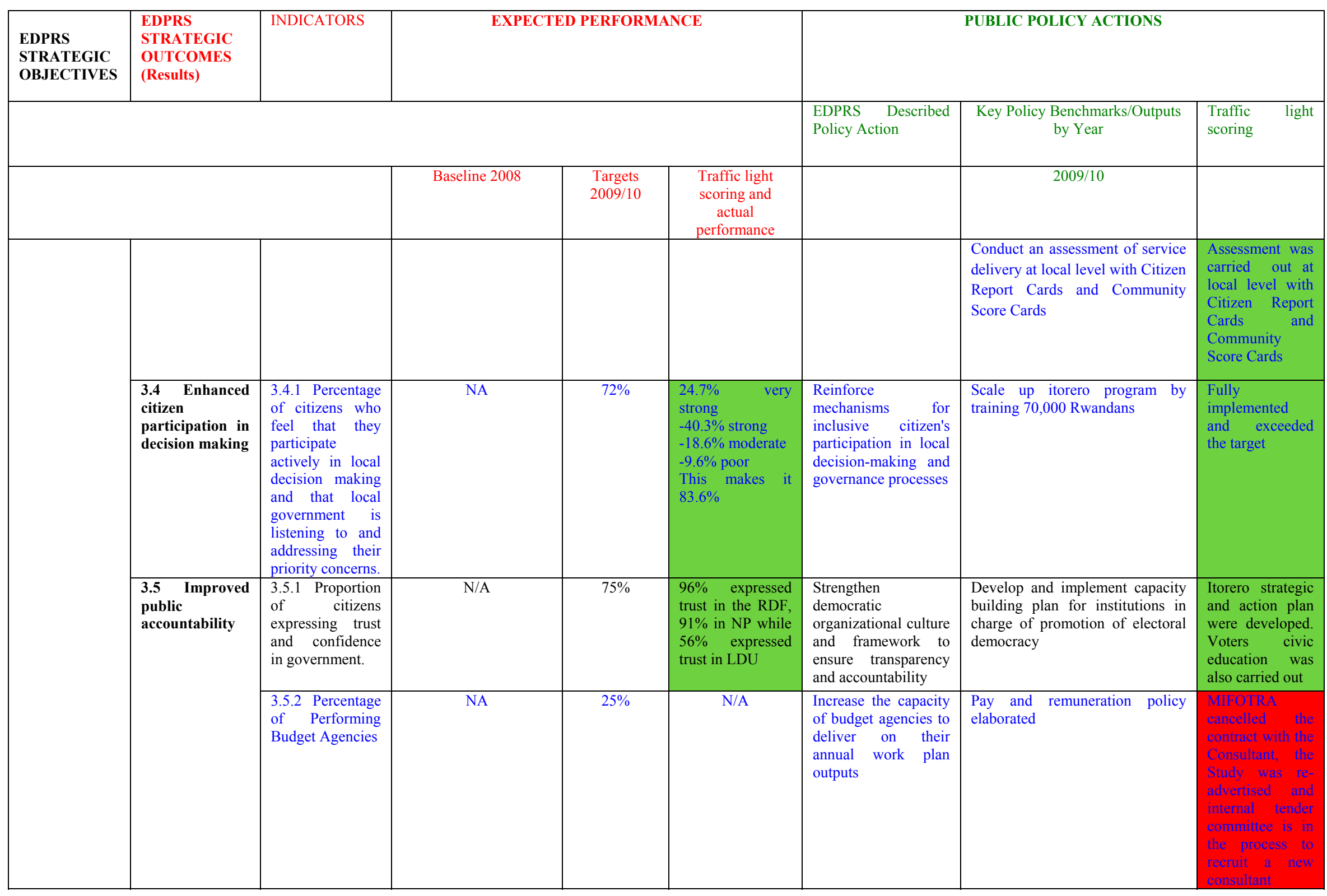




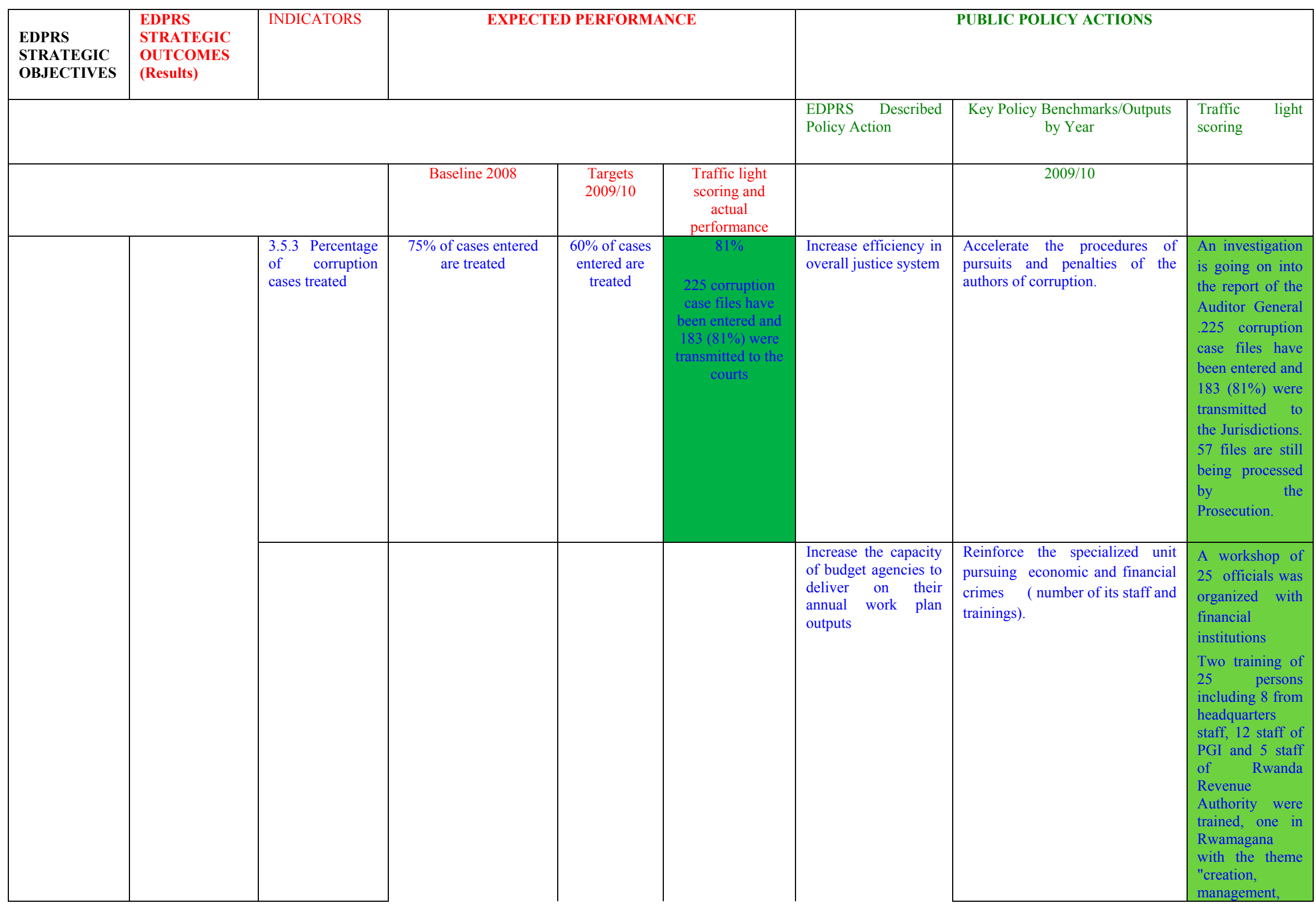




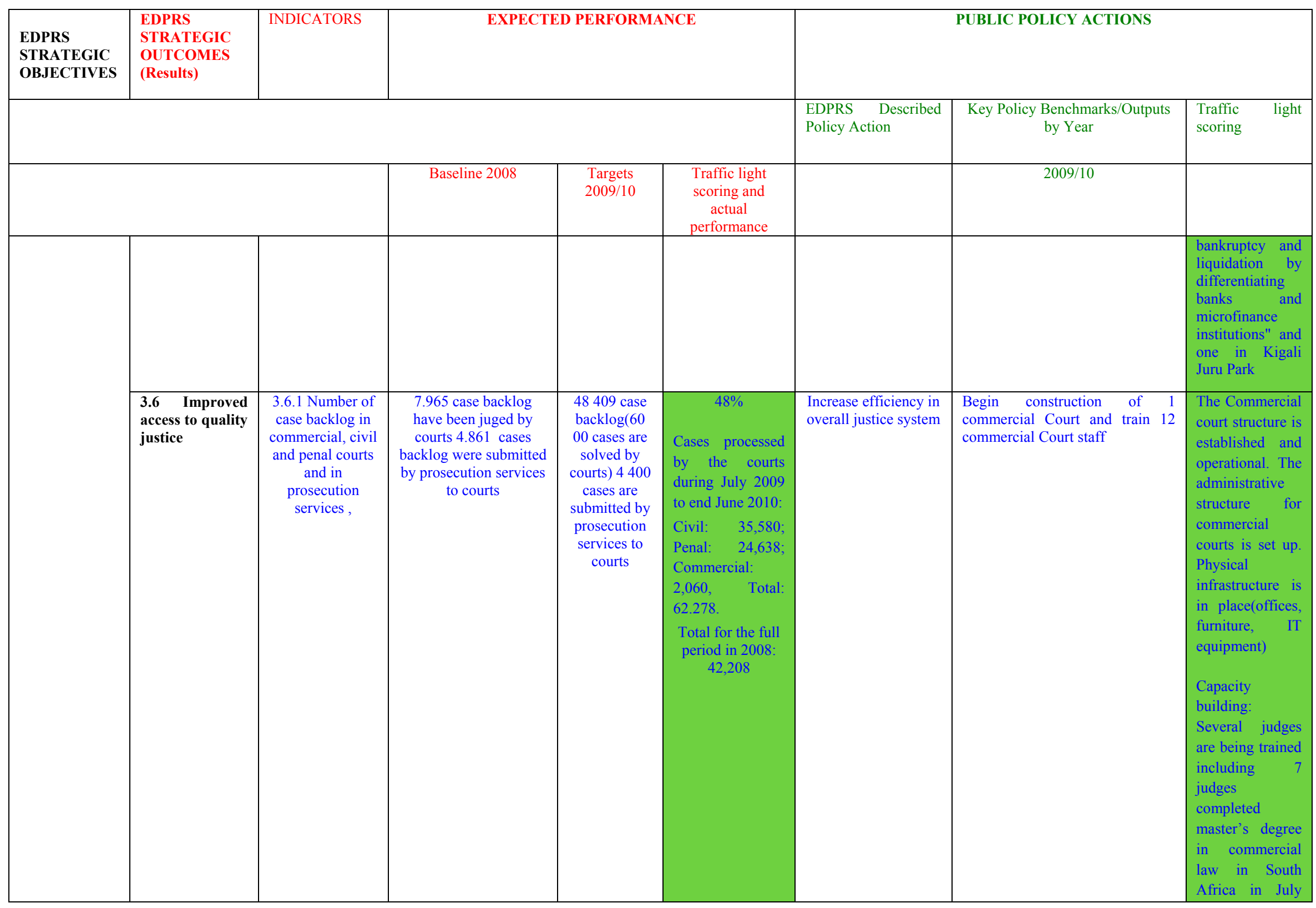




\begin{tabular}{|c|c|c|c|c|c|c|c|c|}
\hline $\begin{array}{l}\text { EDPRS } \\
\text { STRATEGIC } \\
\text { OBJECTIVES }\end{array}$ & $\begin{array}{l}\text { EDPRS } \\
\text { STRATEGIC } \\
\text { OUTCOMES } \\
\text { (Results) }\end{array}$ & INDICATORS & \multicolumn{3}{|c|}{ EXPECTED PERFORMANCE } & \multicolumn{3}{|c|}{ PUBLIC POLICY ACTIONS } \\
\hline & & & & & & $\begin{array}{l}\text { EDPRS Described } \\
\text { Policy Action }\end{array}$ & $\begin{array}{l}\text { Key Policy Benchmarks/Outputs } \\
\text { by Year }\end{array}$ & $\begin{array}{ll}\text { Traffic } & \text { light } \\
\text { scoring } & \end{array}$ \\
\hline & & & Baseline 2008 & $\begin{array}{l}\text { Targets } \\
2009 / 10\end{array}$ & $\begin{array}{c}\text { Traffic light } \\
\text { scoring and } \\
\text { actual } \\
\text { performance } \\
\end{array}$ & & (2) & 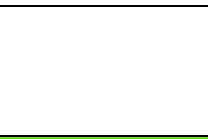 \\
\hline & & & & & & & & $\begin{array}{l}2009,3 \text { judges } \\
\text { are completing } \\
\text { master's degree } \\
\text { in commercial } \\
\text { before } \\
\text { December } 2010, \\
5 \text { more judges } \\
\text { were send to SA } \\
\text { in July } 2010 \text { to } \\
\text { pursue Master's } \\
\text { Degrees. } \\
\text { The commercial } \\
\text { court judges and } \\
\text { registrars have } \\
\text { also been trained } \\
\text { in various } \\
\text { domains like tax } \\
\text { laws, company } \\
\text { law, banking } \\
\text { insurance, } \\
\text { mediation, } \\
\text { contract, } \\
\text { business law, } \\
\text { customer care } \\
\text { and all staff } \\
\text { have been } \\
\text { trained in } \\
\begin{array}{l}\text { English } \\
\text { language }\end{array}\end{array}$ \\
\hline & & & & & & & $\begin{array}{l}\text { JRLO Users perception s survey } \\
\text { published }\end{array}$ & $\begin{array}{l}\text { ToR have been } \\
\text { prepared by the } \\
\text { Coordination } \\
\text { Secretariat. } \\
\text { Advertising was }\end{array}$ \\
\hline
\end{tabular}

CInternational Monetary Fund. Not for Redistribution 


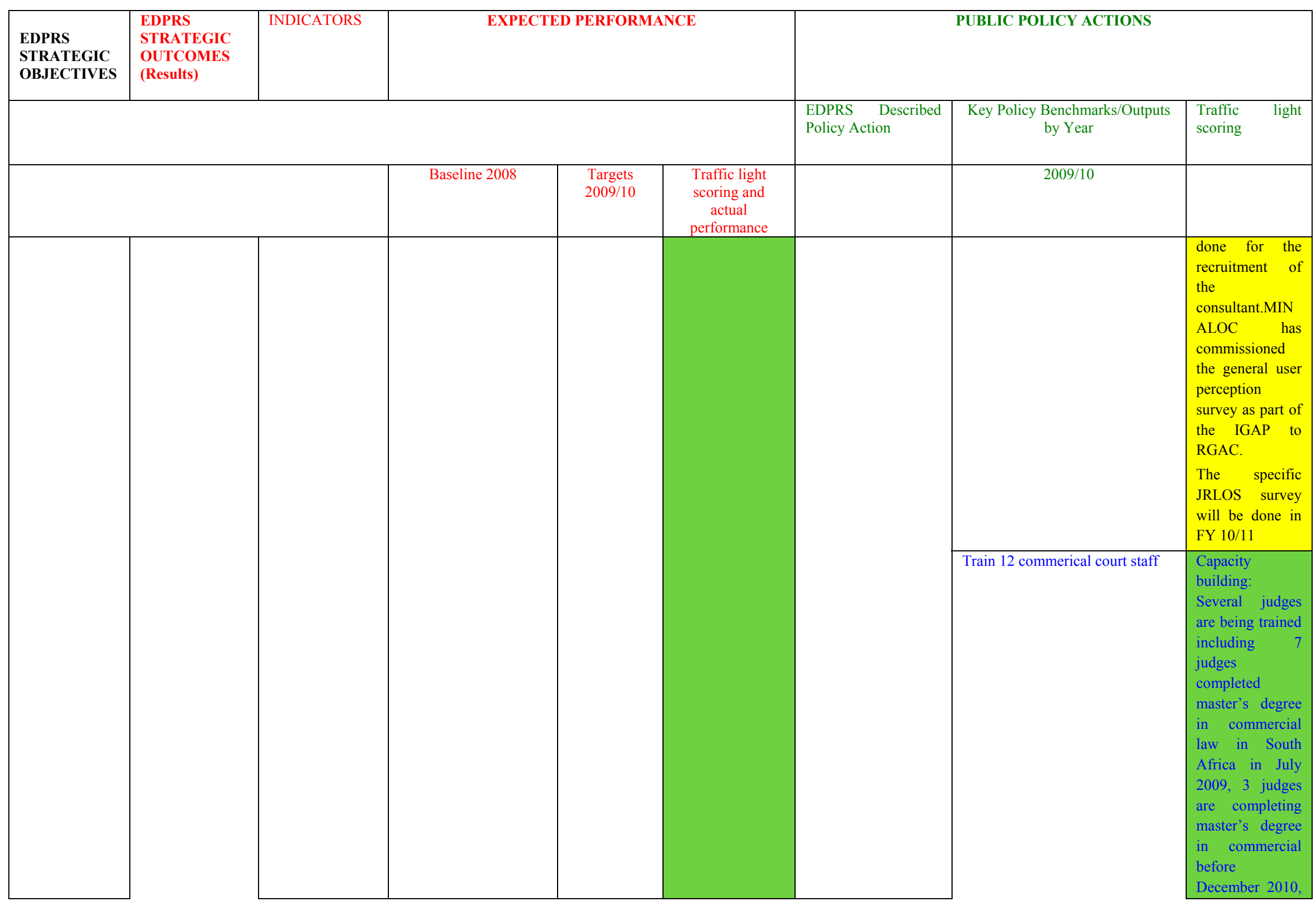

(CInternational Monetary Fund. Not for Redistribution 


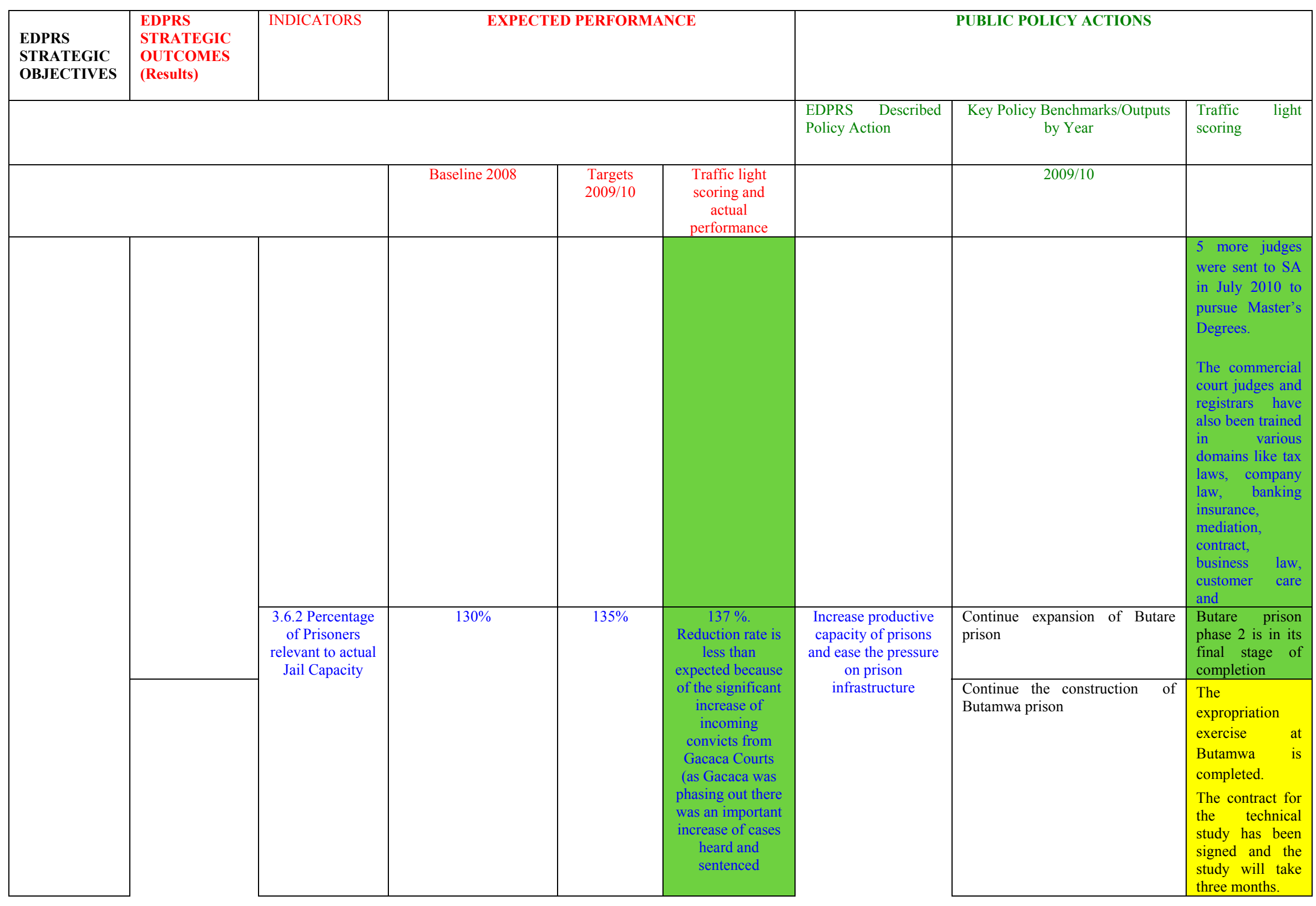

CInternational Monetary Fund. Not for Redistribution 


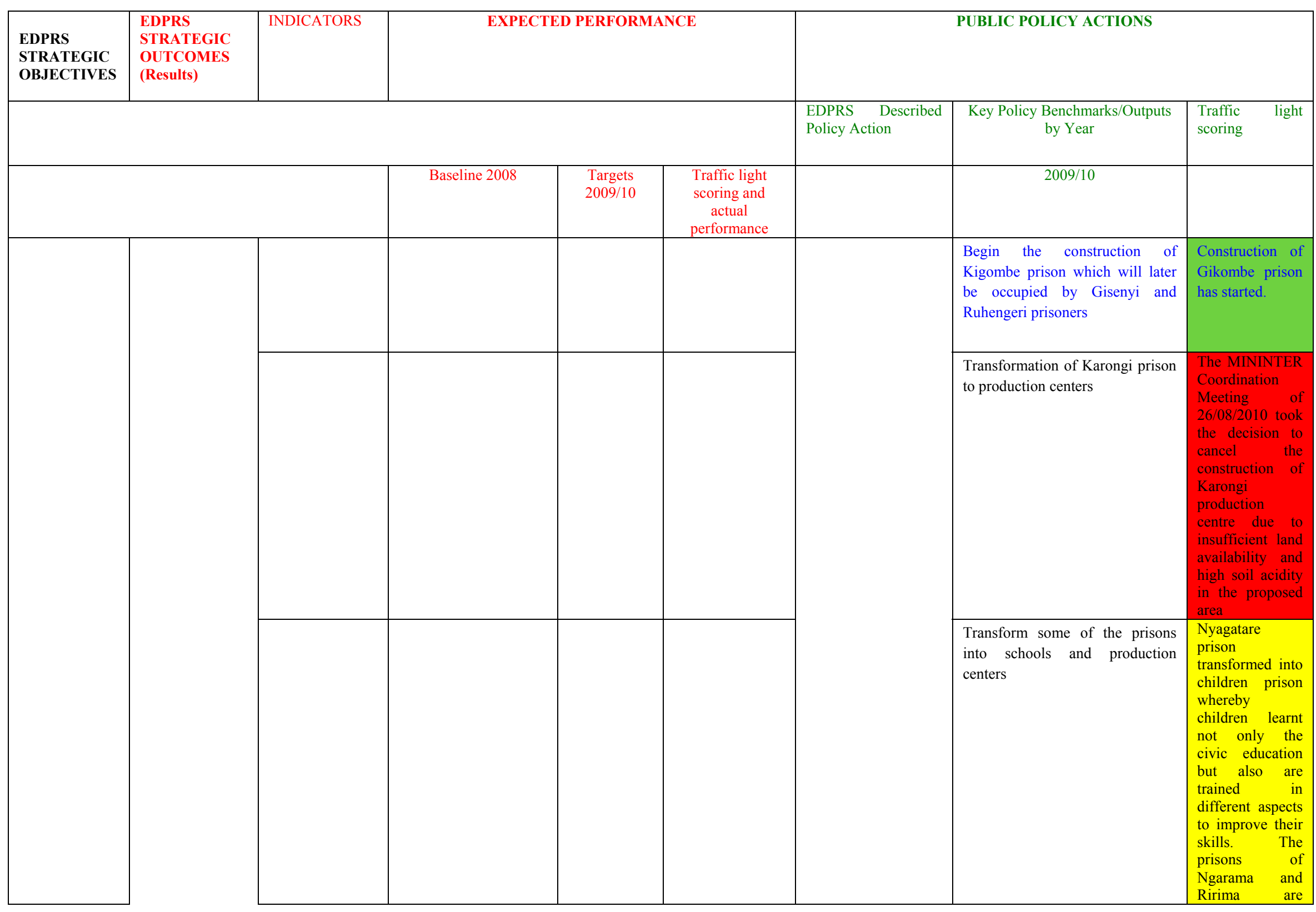

CInternational Monetary Fund. Not for Redistribution 


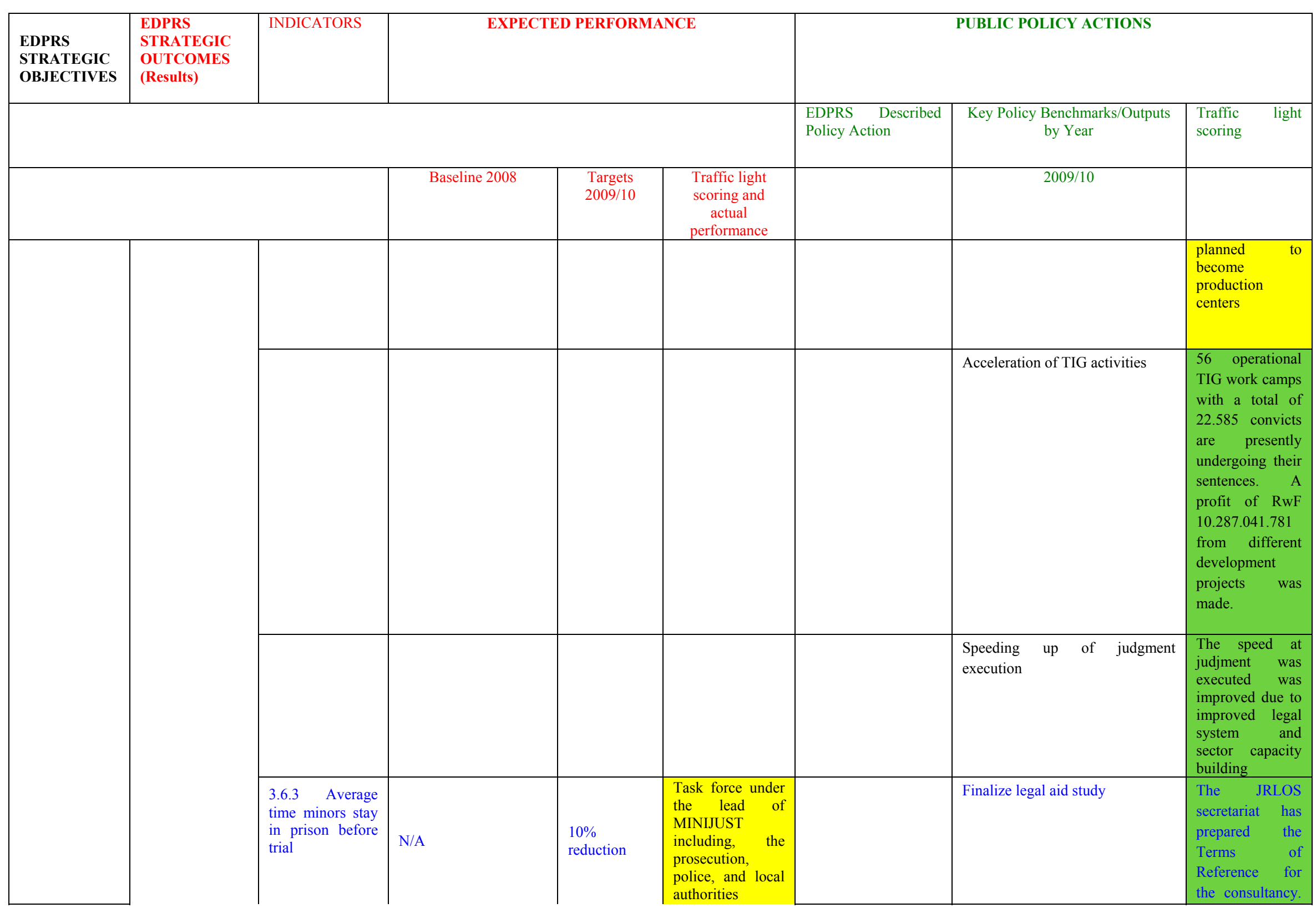

CInternational Monetary Fund. Not for Redistribution 


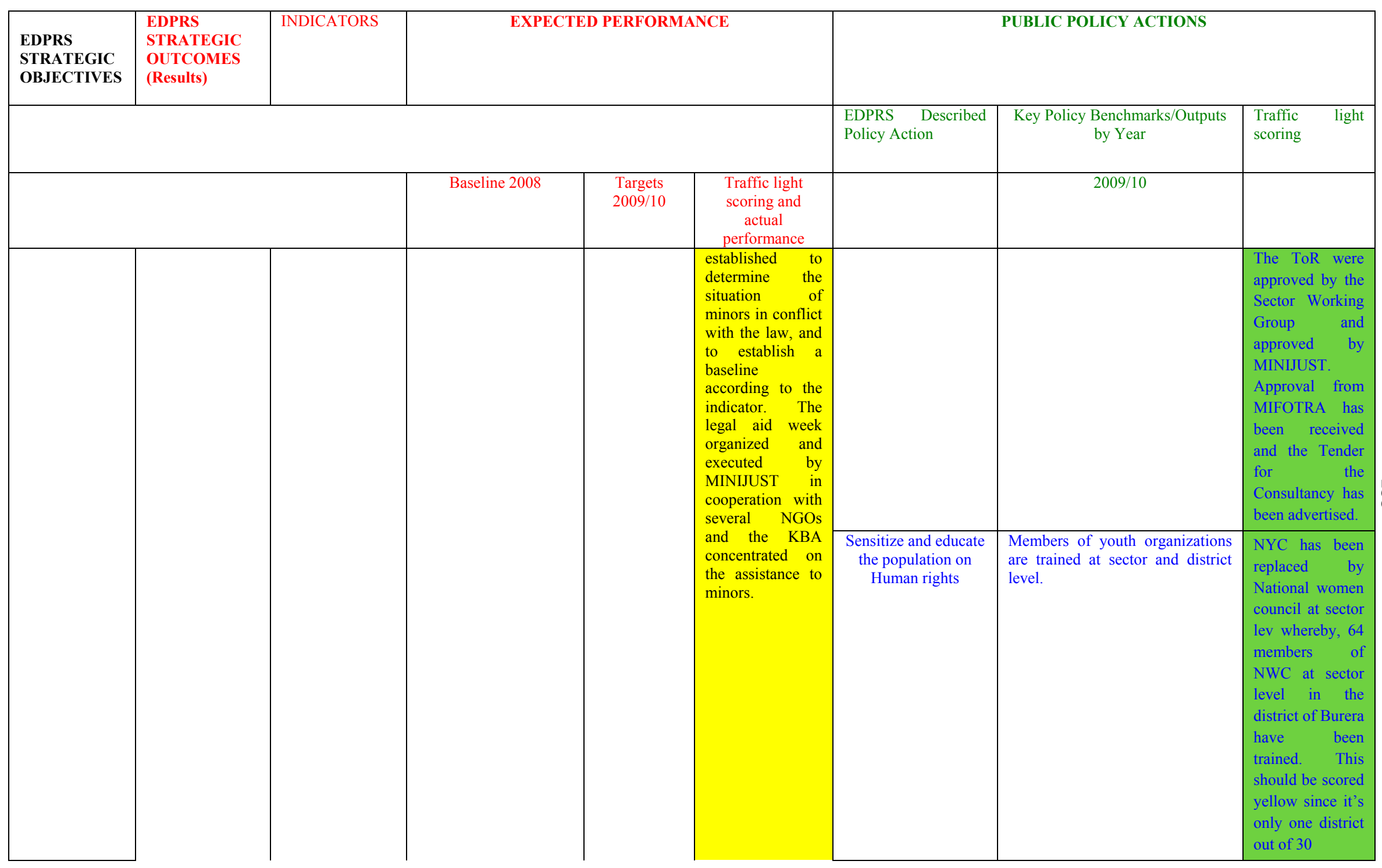




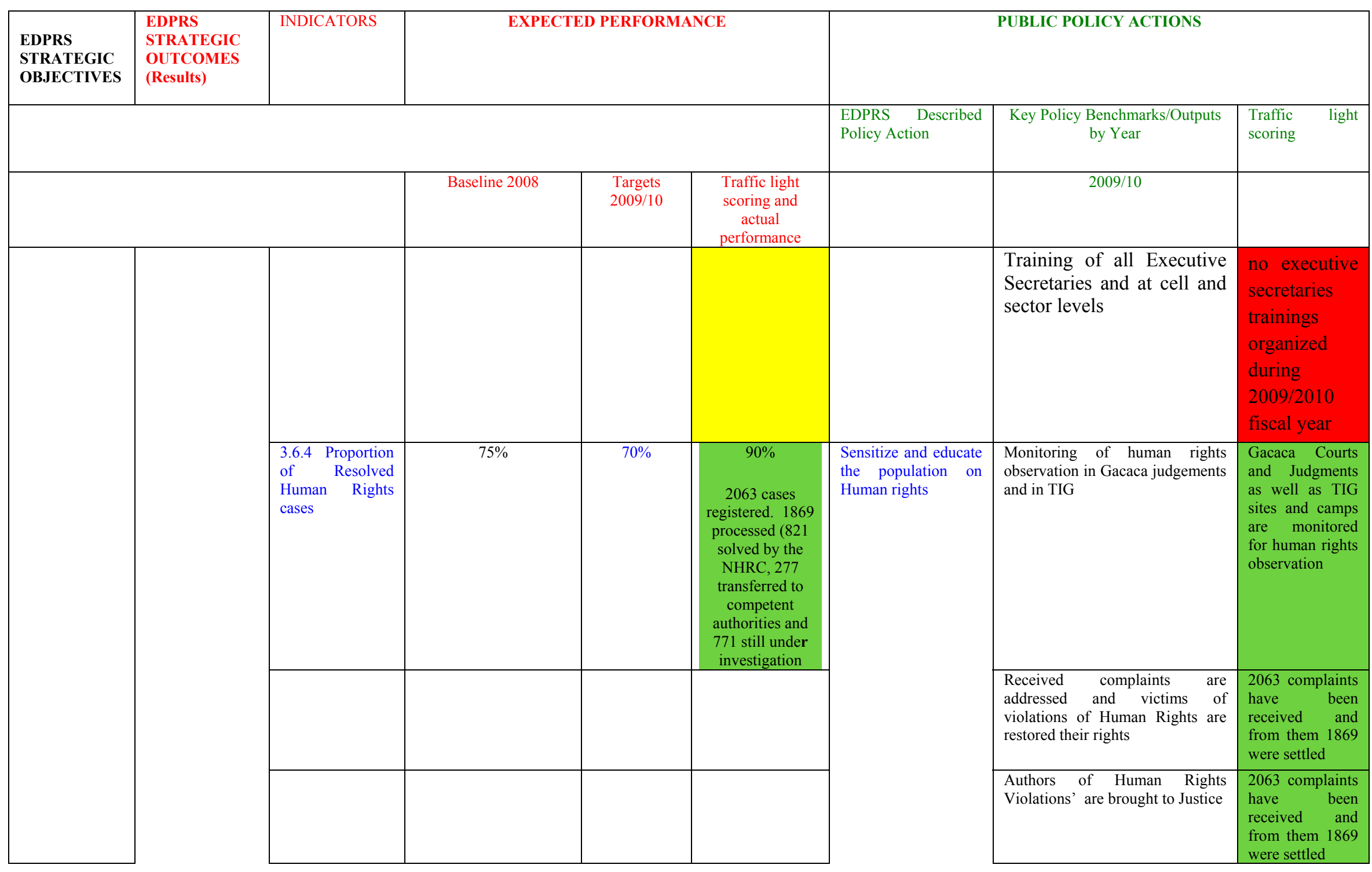




\begin{tabular}{|c|c|c|c|c|c|c|c|c|}
\hline $\begin{array}{l}\text { EDPRS } \\
\text { STRATEGIC } \\
\text { OBJECTIVES }\end{array}$ & $\begin{array}{l}\text { EDPRS } \\
\text { STRATEGIC } \\
\text { OUTCOMES } \\
\text { (Results) }\end{array}$ & INDICATORS & \multicolumn{3}{|c|}{ EXPECTED PERFORMANCE } & \multicolumn{3}{|c|}{ PUBLIC POLICY ACTIONS } \\
\hline & & & & & & $\begin{array}{l}\text { EDPRS Described } \\
\text { Policy Action }\end{array}$ & $\begin{array}{l}\text { Key Policy Benchmarks/Outputs } \\
\text { by Year }\end{array}$ & $\begin{array}{ll}\text { Traffic } & \text { light } \\
\text { scoring } & \end{array}$ \\
\hline & & & Baseline 2008 & $\begin{array}{l}\text { Targets } \\
2009 / 10\end{array}$ & $\begin{array}{l}\text { Traffic light } \\
\text { scoring and } \\
\text { actual } \\
\text { performance }\end{array}$ & & 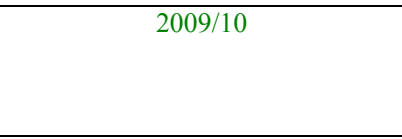 & \\
\hline & $\begin{array}{ll}3.7 & \text { Reduced } \\
\text { crime }\end{array}$ & $\begin{array}{l}3.7 .1 \text { Reduced } \\
\text { crime rate }\end{array}$ & $15 \%$ & $20 \%$ & $\begin{array}{l}\text { During 2008, } \\
12712 \quad \text { crimes } \\
\text { were committed } \\
11989 \text { crimes } \\
\text { were committed, } \\
\text { reported, } \\
\text { registered, } \\
\text { investigated and } \\
\text { sent to } \\
\text { prosecution } \\
\text { during the period } \\
\text { July } 2009 \text { to end } \\
\text { June } 2010 \text {. } \\
\text { Crimes have been } \\
\text { reduced by } \\
7.23 \%\end{array}$ & & Reinforce ADN laboratory & $\begin{array}{l}\text { The } \\
\text { rehabilitation of } \\
\text { Muhima } \\
\text { building in } \\
\text { which a forensic } \\
\text { laboratory will } \\
\text { be located is } \\
\text { under progress. } \\
\text { The completion } \\
\text { of remaining } \\
\text { work will be } \\
\text { finished not later } \\
\text { than December } \\
\text { 2010. A deeper } \\
\text { analysis of the } \\
\text { primary study } \\
\text { for the } \\
\text { establishment of } \\
\text { a fully fletched } \\
\text { forensic } \\
\text { laboratory } \\
\text { including DNA } \\
\text { analysis } \\
\text { revealed that the } \\
\text { investment cost } \\
\text { would absorb } \\
\text { approximately } \\
50 \% \text { of the } \\
\text { present budget } \\
\text { for the police. } \\
\text { The future } \\
\text { incurred } \\
\text { recurrent cost } \\
\text { for such a } \\
\text { laboratory } \\
\text { would also be } \\
\text { too high relative } \\
\text { to the existing }\end{array}$ \\
\hline
\end{tabular}

CInternational Monetary Fund. Not for Redistribution 


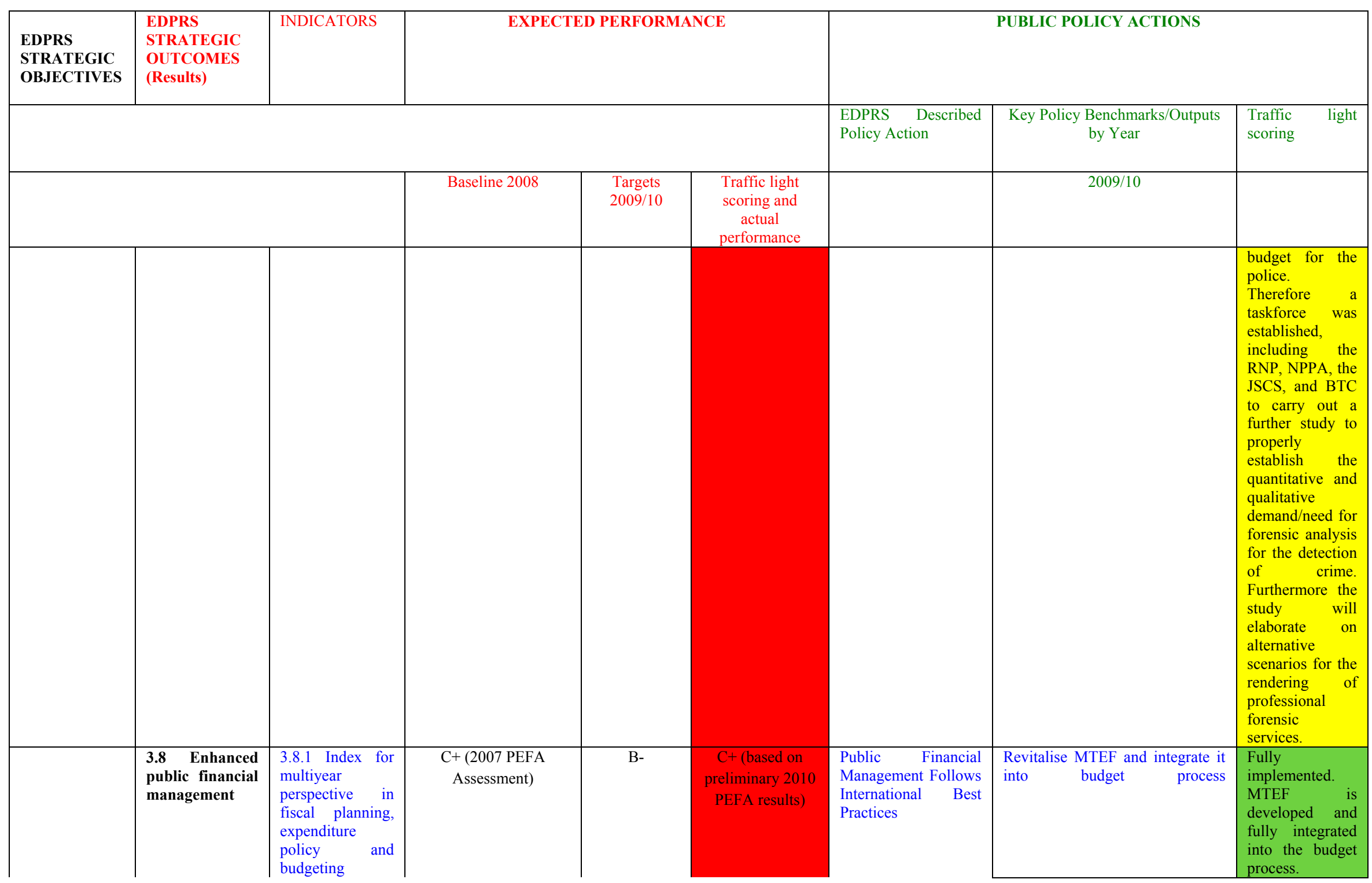




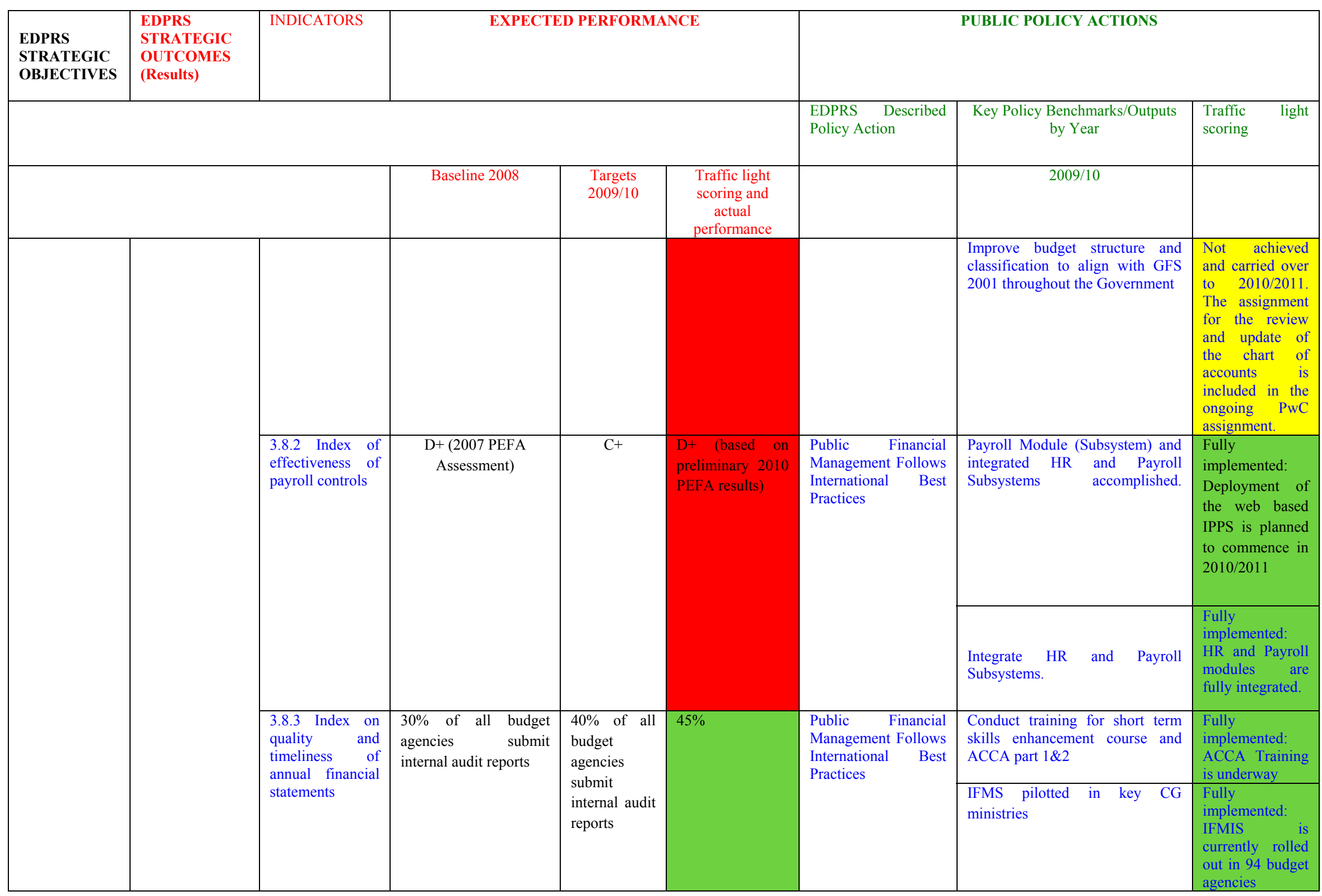

CInternational Monetary Fund. Not for Redistribution 


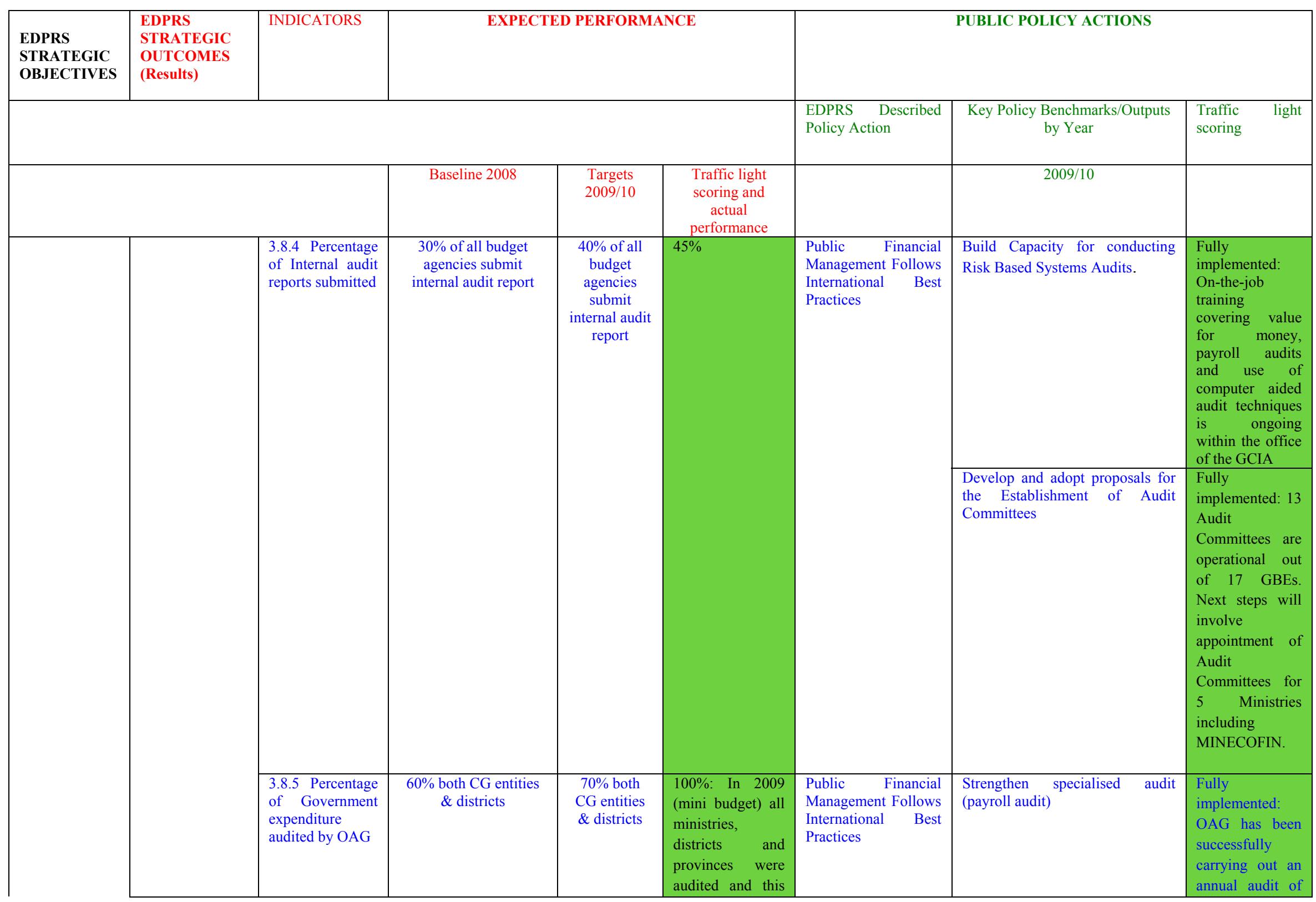

CInternational Monetary Fund. Not for Redistribution 


\begin{tabular}{|c|c|c|c|c|c|c|c|c|}
\hline $\begin{array}{l}\text { EDPRS } \\
\text { STRATEGIC } \\
\text { OBJECTIVES }\end{array}$ & $\begin{array}{l}\text { EDPRS } \\
\text { STRATEGIC } \\
\text { OUTCOMES } \\
\text { (Results) }\end{array}$ & INDICATORS & \multicolumn{3}{|c|}{ EXPECTED PERFORMANCE } & \multicolumn{3}{|c|}{ PUBLIC POLICY ACTIONS } \\
\hline & & & & & & $\begin{array}{l}\text { EDPRS Described } \\
\text { Policy Action }\end{array}$ & $\begin{array}{c}\text { Key Policy Benchmarks/Outputs } \\
\text { by Year }\end{array}$ & $\begin{array}{ll}\text { Traffic } & \text { light } \\
\text { scoring } & \end{array}$ \\
\hline & & & Baseline 2008 & $\begin{array}{l}\text { Targets } \\
2009 / 10\end{array}$ & $\begin{array}{c}\text { Traffic light } \\
\text { scoring and } \\
\text { actual } \\
\text { performance } \\
\end{array}$ & & $2009 / 10$ & \\
\hline & & & & & $\begin{array}{l}\text { achievement is } \\
\text { planned to be met } \\
\text { for the } 2009 / 2010 \\
\text { audit exercise }\end{array}$ & & & $\begin{array}{l}\text { the Government } \\
\text { payroll. }\end{array}$ \\
\hline & & & & & & & Implement staff retention strategy & \\
\hline & & $\begin{array}{l}\text { 3.8.6 Percentage } \\
\text { of Public } \\
\text { enterprise } \\
\text { submitting fiscal } \\
\text { reports }\end{array}$ & $\begin{array}{l}\text { All GBEs submitted } \\
\text { reports; }\end{array}$ & $\begin{array}{l}43 \% \text { of } \\
\text { GBEs submit } \\
\text { fiscal reports; } \\
\text { all reports } \\
\text { consolidated }\end{array}$ & $100 \%$ & $\begin{array}{lr}\text { Public } & \text { Financial } \\
\text { Management } & \text { Follows } \\
\text { International } & \text { Best } \\
\text { Practices } & \end{array}$ & $\begin{array}{l}\text { Implement and monitor the } \\
\text { government } \\
\text { management strategy }\end{array}$ & $\begin{array}{l}\text { The government } \\
\text { portfolio } \\
\text { strategy is in } \\
\text { place; a fully } \\
\text { fledged unit was } \\
\text { established to } \\
\text { analyze and } \\
\text { compile reports } \\
\text { on fiscal risks } \\
\text { posed by GBEs; } \\
\text { a fiscal risk } \\
\text { review report for }\end{array}$ \\
\hline
\end{tabular}

CInternational Monetary Fund. Not for Redistribution 


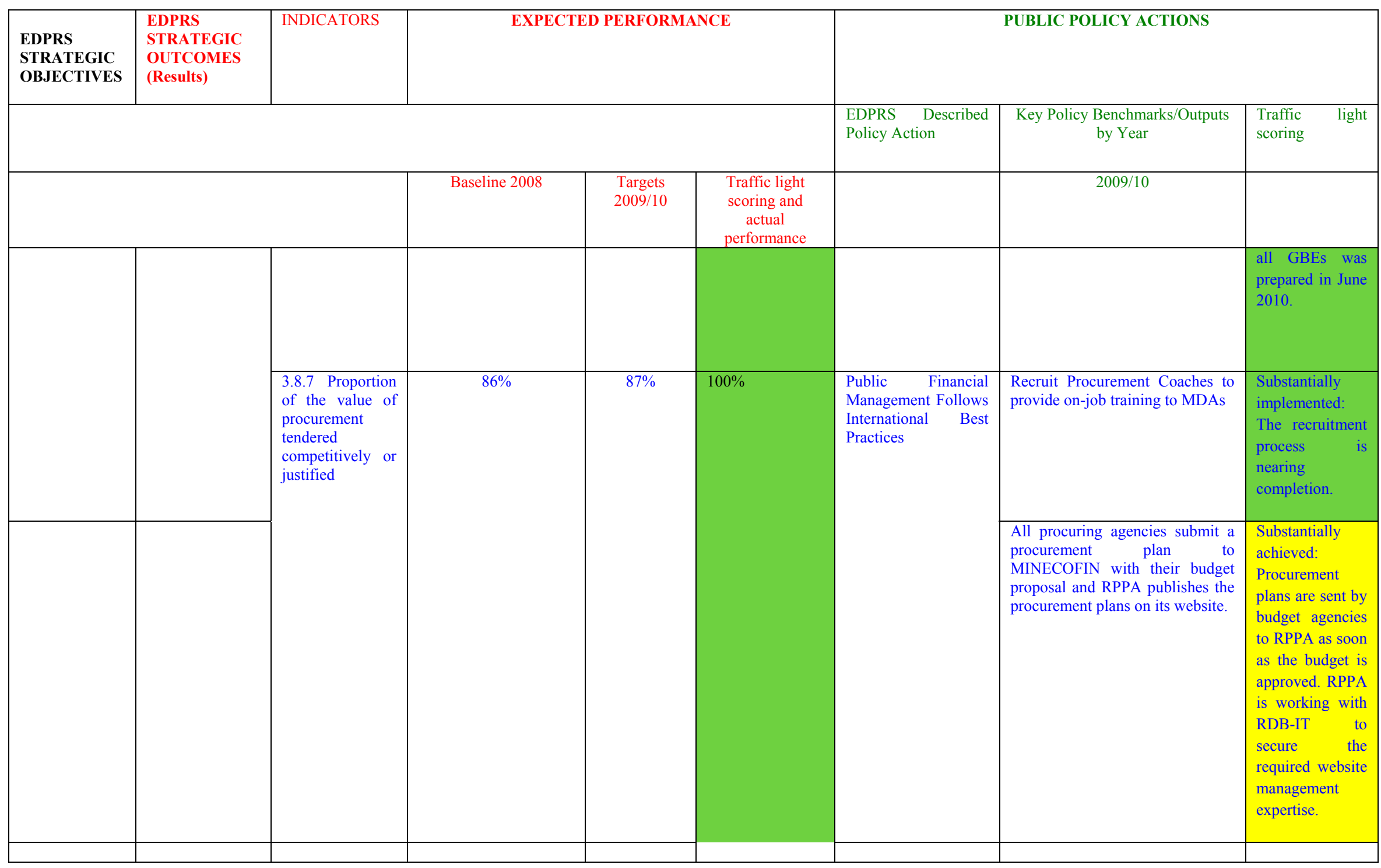

CInternational Monetary Fund. Not for Redistribution 